\title{
Ipomoea (Convolvulaceae) in Bolivia
}

\author{
John R. I. Wood ${ }^{1,2}$, M. A. Carine ${ }^{3}$, D. Harris ${ }^{4}$, P. Wilkin², B. Williams ${ }^{1}$ \& R. W. Scotland ${ }^{1}$
}

Summary. An account of the genus Ipomoea L. in Bolivia is presented. 102 species are recognised in the country and each of these is described. Notes are provided on diagnostic features, distribution, habitat, phenology and conservation status. A dichotomous key to all species is provided together with additional informal keys focussing on outstanding features of morphology and ecology. Line drawings illustrate the new species described and photographs are provided to facilitate identification and draw attention to key diagnostic features. Maps of the distribution in Bolivia of selected species are also provided. 18 species are described as new of which 14 are endemic to Bolivia: Ipomoea appendiculata J. R. I. Wood \& Scotland, I. chiquitensis J. R. I. Wood \& Scotland, I. exserta J. R. I. Wood \& Scotland, I. juliagutierreziae J. R. I. Wood \& Scotland, I. gypsophila J. R. I. Wood \& Scotland, I. huayllae J. R. I. Wood \& Scotland, I. lactifera J. R. I. Wood \& Scotland, I. longibarbis J. R. I. Wood \& Scotland, I. mendozae J. R. I. Wood \& Scotland, I. mucronifolia J. R. I. Wood \& Scotland, I. odontophylla J. R. I. Wood \& Scotland, I. paradae J. R. I. Wood \& Scotland, I. psammophila J. R. I. Wood \& Scotland and I. spinulifera J. R. I. Wood \& Scotland. The remaining four are also found in Brazil: I. cerradoensis J. R. I. Wood \& Scotland, I. cryptica J. R. I. Wood \& Scotland, I. graniticola J. R. I. Wood \& Scotland and I. mucronatoproducta J. R. I. Wood \& Scotland. Of particular interest is I. lactifera which is a crop wild relative of the sweet potato. The name I. paludicola J. R. I. Wood \& Scotland is provided for the plant usually treated as a form of I. asarifolia (Desr.) Roem. \& Schult. but originally described by Meisner under the illegitimate name I. serpens Meisn. The new combination I. hewittacea (Kuntze) J. R. I. Wood \& Scotland is made and is the correct name for the plant currently known as I. piresii O'Donell. The hitherto accepted names $I$. echioides Choisy, I. pedata G. Don, I. peredoi O'Donell, I. philipsonii O'Donell, I. piurensis O'Donell, I. santacrucensis O'Donell, I. sawyeri D. F. Austin and I. tapirapoanensis Hoehne are treated as synonyms of, respectively, I. paulistana (Silva Manso) Stellfeld, I. mauritiana Jacq., I. reticulata O'Donell, I. batatoides Choisy, I. acanthocarpa (Choisy) Aschers. \& Schweinf., I. oranensis O’Donell, I. neurocephala Hallier f., and I. caloneura Meisn. I. subtomentosa (Chodat \& Hassl.) O'Donell is treated as a var. subtomentosa (Chodat \& Hassl.) J. R. I. Wood \& Scotland of I. maurandioides Meisn. and a new variety erecta J. R. I. Wood \& Scotland is described for I. bonariensis Hook. The following taxa are lectotypified: I. serpens Meisn., I. rubens Choisy, I. procurrens Meisn, I. chiliantha Hallier f., I. pinifolia Meisn., I. incarnata (Vahl) Choisy, I. hirsutissima var. boliviana Meisn., I. virgata Meisn., I. chondrosepala Hallier f., I. argentea Meisn., I. bonariensis Hook., I. pedata G. Don, I. magnifolia Rusby, I. purpurea var. diversifolia (Lindl.) O’Donell, Convolvulus paulistanus Silva Manso, C. cymosus Ruiz \& Pavon and C. indivisus Vell., the last three being basionyms of $I$. paulistana, I. ramosissima Choisy and I. indivisa (Vell.) Hallier f. respectively. A neotype is provided for I. megapotamica Choisy to ensure current usage is maintained. Species of Turbina Raf. occurring in Bolivia are treated as belonging to Ipomoea based on ongoing molecular studies resulting in the new combination I. amazonica (D. F. Austin \& Staples) J. R. I. Wood \& Scotland and a new name I. sericosepala J. R. I. Wood \& Scotland for Turbina cordata (Choisy) D. F. Austin \& Staples.

Key Words. Argentina, Brazil, chorology, conservation, crop wild relative, distribution, ecology, endemism, new species, Paraguay, Peru, phenology, South America, taxonomy.

\section{Introduction}

Bolivia has a diverse flora of approximately 12,165 native species of vascular plants (Jorgensen et al. 2015) reflecting the varied habitats found in the country. As recognised here Ipomoea has 102 species thus placing it within the top ten genera for size in the Bolivian flora.

\footnotetext{
Accepted for publication 13 July 2015.

1 Department of Plant Sciences, University of Oxford, South Parks Road, Oxford, OX1 3RB, UK. e-mail: robert.scotland@plants.ox.ac.uk

2 Royal Botanic Gardens, Kew, Richmond, Surrey, TW9 3AB, UK.

3 Natural History Museum, Cromwell Road, London, SW7 5BD, UK

4 Royal Botanic Garden, 20A Inverleith Row, Edinburgh, EH3 5LR, UK.
} 
It is also of some importance in the economy as the sweet potato, Ipomoea batatas (L.) Lam., is commonly cultivated for its tubers, especially in the Yungas of La Paz and parts of the Beni. Several species are also cultivated for their ornamental flowers.

Our knowledge of the presence and distribution of Ipomoea species in Bolivia has increased enormously in recent years. Probably the first species to be collected in Bolivia was I. haenkeana Choisy, but others were found at regular intervals throughout the $19^{\text {th }}$ century as a result of the travels of D'Orbigny, Mandon, Kuntze, Rusby, Bang and others. However, by 1958 Foster could only list 33 specific names within the three genera Ipomoea, Pharbitis Choisy and Calonyction Choisy, which are all now regarded as belonging to Ipomoea, and, of these 33 names, only 21 correspond to distinct species as recognised today, the other 12 being misidentifications or synonyms of one kind or another. In the slightly more than 50 years since Foster's checklist the total number of species has risen to 102 , a nearly fivefold increase, and, of these, 18 are described as new in this paper.

In the neotropics Ipomoea comprises $400-450$ species but these species are not distributed equally throughout the region. They are concentrated in the 15 - 25 degree latitudes of both hemispheres with major centres of diversity and endemism in the northern hemisphere in Mexico, Cuba and the island of Hispaniola, and in the southern hemisphere in the southern half of Brazil and the greater Chaco region, which our molecular studies (Williams et al. in prep.) show to be the geographical centre of a major radiation of species. It is not surprising, therefore, that the majority of species recognised for Bolivia are found in the south of the country in the Departments of Chuquisaca, Santa Cruz and Tarija.

Ipomoea species are found in a wide range of habitats in tropical and subtropical parts of the country but are uncommon above approximately $2000 \mathrm{~m}$ although I. plummerae A. Gray reaches $4000 \mathrm{~m}$ in the Bolivian Andes. They are entirely absent from the altiplano. However, they are present in all kinds of lowland habitat including evergreen tropical rainforest, deciduous or semi-deciduous dry forest, open savannas, semi-desert and swamp. They are often common in ruderal habitats, along forest tracks, by streams and rock outcrops and thrive in secondary bushland.

\section{Materials and methods}

This account is based in part on the field work of the first author, who has lived and worked in Bolivia for lengthy periods since 1993 and has made efforts to collect Ipomoea species and observe their characteristics in the field. However, the work of a number of younger Bolivian botanists should not be underestimated. They have played a significant part in increasing our knowledge, particularly but not exclusively as a result of their involvement in projects linked to the Missouri Botanical Garden or the Darwin Initiative. A majority of the new species and new records were found as a result of these projects, particularly those based in eastern Bolivia.

During the course of this study all literature related to Bolivian Ipomoea has been consulted and most type specimens have been traced. Herbarium specimens have been examined in all four recognised Bolivian herbaria (BOLV, HSB, LPB, USZ) as well as in herbaria in other countries which have important holdings of Bolivian plants, especially MO, NY and US in the United States, CTES and LIL in Argentina, and $\mathrm{K}$ and $\mathrm{BM}$ in the United Kingdom. We have been able to create a database of over 1550 records of Ipomoea from Bolivia which is available on request from the corresponding author. Herbarium collections have yielded many new records and the occasional new species, such as I. gypsophila J. R. I. Wood \& Scotland, discovered as the result of examination of old specimens in the herbarium at Tucuman (LIL). However, the overwhelming majority of new discoveries were made as a result of exploration in the field, a testimony both to our ignorance of the Bolivian flora in the past and to the importance of recent field work.

Another important aspect of our research is its inclusion within the broader context of the Foundation Monograph Project studying Ipomoea worldwide. We have studied extensive material from neighbouring countries and have built on earlier taxonomic decisions, particularly those of the Argentinian botanist Carlos O'Donell as well as more recent workers including Dan Austin and Rosangela Simão-Bianchini. In addition our studies have benefitted from the insights of our on-going molecular studies whose results will be published separately in a wide-ranging paper (Williams et al. in prep.). These have done much to confirm taxonomic decisions based on morphology and in many cases have provided assurance that our new species are wellfounded monophyletic entities. They have provided support to unite I. piurensis O'Donell with I. acanthocarpa (Choisy) Aschers. \& Schweinf. from Africa, to separate I. paludicola J. R. I. Wood \& Scotland from I. asarifolia (Desr.) Roem. \& Schult., and to recognise the cryptic species, I. cryptica J. R. I. Wood \& Scotland.

Our molecular studies have also demonstrated that Turbina Raf. is an entirely artificial polyphyletic construct. Our concept of Ipomoea has been widened to include the American species of Turbina Raf., a genus previously maintained on the basis of having one-seeded capsules. Seed number is not constant in several species of Ipomoea, including some of those previously placed in Turbina. The four Bolivian species previously placed in Turbina (I. abutiloides (Kunth) G. 
Don, I. amazonica (D. F. Austin \& Staples) J. R. I. Wood \& Scotland, I. corymbosa (L.) Roth ex Roem. \& Schult. and I. sericosepala J. R. I. Wood \& Scotland) belong to three distinct clades (Williams et al. in prep.). The African species of Turbina are in a fourth, quite separate, clade.

In the following treatment species are arranged to reflect major clades inferred from molecular sequence data (Williams et al. in prep.), as far as it is possible in a linear sequence. Within major clades the order of species is more or less arbitrary albeit with similar species placed together when obvious. We have succeeded in sequencing all species found in Bolivia with the exception of Ipomoea gypsophila J. R. I. Wood \& Scotland and I. paradae J. R. I. Wood \& Scotland, whose positions have been inferred on the basis of morphology. These studies confirm the accepted circumscription of sect. Batatas (Choisy) Griseb. (Species 70 - 75) and sect. Quamoclit (Moench.) Griseb. (Species 93 - 97), a narrow circumscription of sect. Pharbitis (Choisy) Griseb. (Species $79-84$ ) and indicate the existence of several other important infrageneric groupings, notably a major radiation in the Chaco (Species 28 - 48) and a second large clade with coriaceous sepals (Species 56 - 69). No formal infrageneric structure is proposed here and may not be possible to produce in the near future.

It is worth noting that several characters of practical value used to subdivide the genus by Choisy (1845) and Meisner (1869) have little phylogenetic significance. Both habit and corolla structure seem to have evolved separately on different occasions as adaptations to different habitats or pollinators. The erect habit has evolved in several different lineages as an adaptation to the savannah habitat whether in Africa, North America or the South American cerrados. White night-flowering, hawkmoth-pollinated species are also polyphyletic and widely distributed, occurring over the same geographical range although somewhat less commonly in South America. Tubular red-flowers presumed to be adaptations for humming bird pollination also evolved independently within Ipomoea.

Our approach to species delimitation is essentially conservative and we have mostly retained several pairs of long-recognised but occasionally intergrading species that cannot be clearly separated given the molecular data we have gathered thus far. These pairs are: Ipomoea abutiloides and I. sericosepala, I. amnicola Morong and I. chiliantha Hallier f., I. cheirophylla O'Donell and I. mauritiana Jacq., I. reticulata O'Donell and I. saopaulista O'Donell, I. cordatotriloba Dennst. and I. grandifolia (Dammer) O'Donell, this last pair accepted pending a wide-ranging revision of sect. Batatas. The species in each pair occupy a somewhat different geographical or ecological niche and can usually be distinguished but often by unsatisfactory characters such as corolla size. Subspecific status may prove appropriate eventually but we think it is premature to make these changes.

\section{Chorology}

The 102 species of Ipomoea represent most of the distinct phytogeographical elements that make up the Bolivian flora as recognised in Jorgensen et al. (2015). Although some species do not fit comfortably, the vast majority of species clearly belong to one or other of the following elements:

1. Introductions which are not yet naturalised and only occur in or close to gardens: Ipomoea batatas, I. indica (Burm.) Merr., I. lobata (Cerv.) Thell. and I. tricolor Cav. Of these I. indica is surprisingly rare despite being locally abundant and well naturalised in all neighbouring countries. All four are of American origin, probably originating in the Mexican region.

2. Widespread pantropical or neotropical species which are common in disturbed habitats. Most of these are of certain or probable American origin (Ipomoea acanthocarpa, I. alba L., I. carnea Jacq., I. corymbosa., I. fimbriosepala Choisy, I. hederifolia L., I. mauritiana, I. muricata (L. ) Jacq., I. nil (L.) Roth, I. purpurea (L.) Roth, I. quamoclit L., I. setifera Poir. and I. wrightii A. Gray) but two (I. cairica (L.) Sweet and I. rubens Choisy) probably originated in the Old World. Two further species (I. parasitica (Kunth) G. Don and I. setosa Ker-Gawl.) should be included in this category because they are widely distributed in the neotropics although not reported as naturalised in the Old World. Although all these species usually occur in disturbed habitats such as roadsides, some (I. carnea, I. hederifolia, I. setifera, for example) are almost certainly native and the others all occur at least sometimes as a component of natural vegetation with every appearance of being native. The 21 species in these first two categories are extraordinarily widespread, all being recorded, for example, for Flora Mesoamericana except I. acanthocarpa and I. fimbriosepala (Austin et al. 2012) and all except I. acanthocarpa, I. corymbosa, I. muricata, I. parasitica, I. setifera and I. setosa from Madagascar (Deroin 2001).

3. Species of moist and seasonally moist tropical forest: This is an important component of the Ipomoea flora of Bolivia and comprises some ten species which are restricted to the tropical lowlands and Andean foothills of Bolivia north of about $18^{\circ}$ south. Of these species I. batatoides Choisy, I. philomega (Vell.) House, I. ramosissima Choisy, I. reticulata and I. squamosa Choisy all extend into Central America and Mexico. I. abutiloides (to Panama) and I. regnellii Meisn. (to Colombia) are widespread species in the South American tropical lowlands but two species, I. lactifera J. R. I. Wood \& Scotland and I. opulifolia Rusby are apparently endemic to Bolivia and occur in the tropical forests in and close to the Andean foothills. 
The distribution of I. cryptica is uncertain but almost certainly occurs in Brazil as well as Bolivia. (Maps 3, 6).

4. Species of the Yungas: The moist forest of the eastern Andean slopes up to about $2500 \mathrm{~m}$ lying north of about $18^{\circ}$ south are usually rich in endemic species; in Acanthaceae, for example, all ten species of Stenostephanus Nees are restricted to this habitat and eight are endemic to Bolivia. Ipomoea, however, is poorly represented. Only I. magnifolia Rusby, which extends to Peru, is really typical of this category although the endemic species I. lactifera, I. cryptica, I. opulifolia and I. paradae J. R. I. Wood \& Scotland might be interpreted as Yungas species. None, however, occur above $600 \mathrm{~m}$ and the range of the first three extends onto the plains while I. paradae is restricted to the Santa Cruz area. Map 16.

5. Andean species: These are here defined as species found mostly above $1500 \mathrm{~m}$ in altitude. The group consists of nine species: Ipomoea aristolochiifolia G. Don, I. clavata (G. Don) Ooststr. ex J. F. Macbride (anomalous for being found at low altitudes), I. dumetorum Willd. ex Roem. \& Schult., I. plummerae A. Gray, I. pubescens Lam., I. neurocephala Hallier f. and the three new endemic species I. juliagutierreziae J. R. I. Wood \& Scotland of the Arborescens group and two related to I. aristolochiifolia, I. huayllae J. R. I. Wood \& Scotland and I. odontophylla J. R. I. Wood \& Scotland. With the exception of these last three species, all species in this category extend along the Andean chain from the south to the north of Bolivia (Maps 19 - 22) and from Argentina north to Mexico and the United States, although in several cases with significant gaps in this distribution.

6. Tucuman-Bolivian species: These are defined as species with an Andean distribution extending from northern Argentina to central Bolivia. They are essentially species of the inter-Andean dry valleys and Bosque Serrano Chaqueño growing at intermediate altitudes from around 500 to $2000 \mathrm{~m}$ south of about $18^{\circ} \mathrm{S}$. They include Ipomoea hieronymi (Kuntze) O'Donell, I. lilloana O'Donell, I. marginsepala O'Donell, I. oranensis O'Donell, I. rubriflora O'Donell and I. schulziana O'Donell. I. cheirophylla is somewhat anomalous in that also occurs in the Chaco and other lowland regions but loosely conforms. This category is particularly rich in Bolivian endemics including I. appendiculata J. R. I. Wood \& Scotland, I. exserta J. R. I. Wood \& Scotland, I. gypsophila, I. mendozae J. R. I. Wood \& Scotland, I. spinulifera J. R. I. Wood \& Scotland and I. tarijensis O'Donell as well as three near-endemics, I. lilloana, I. oranensis and I. schulziana. Maps 13, 16.

7. Chaco: These species have their distribution centred on the Chaco of north eastern Argentina, Paraguay, SE Bolivia and SW Brazil. Typical species include Ipomoea argentinica Peter, I. bonariensis Hook., I. chiliantha, I. vivianae Krapov., I. chondrosepala
Hallier f., I. megapotamica Choisy, (these last two absent from Argentina, but present in Brazil), I. amnicola, I. cordatotriloba Dennst. and I. crinicalyx S. Moore (these three anomalous for their amphitropical distribution being also found in North America). Endemic species are I. densibracteata O'Donell, I. longibarbis J. R. I. Wood \& Scotland, I. mucronifolia J. R. I. Wood \& Scotland and I. psammophila J. R. I. Wood \& Scotland, the last three being clearly part of the radiation of species related to such typical chaco plants as I. argentinica, I. pseudocalystegia Hassler, I. nitida Griseb. and I. lanuginosa O'Donell but all very restricted in their distribution and atypical in different ways. I. longibarbis has a distribution more typical of the Tucuman-Bolivian group (Map 11) while I. mucronifolia and I. psammophila occur in the Chaco-Cerrado transition. I. densibracteata belongs to a different clade and is more widely distributed than other endemics with a chaco-type distribution. Map 7.

8. Pantanal and Sabanas Benianas: These species are centred on the Pantanal and show Brazilian rather than Paraguayan links: This group is represented by four species in Bolivia: Ipomoea amazonica, I. paludicola, I. mucronatoproducta J. R. I. Wood \& Scotland and I. cardenasiana O' Donell, the last two being rare species, which together with two as yet undescribed species from Brazil form a group of Pantanal endemics. All appear to be most common in Mato Grosso.

9. Cerrado: This is an important element in the Ipomoea flora comprising 20 species in eastern Bolivia and consists of two distinct groups: the first group consists of three species of wetland habitats associated with the cerrado, all three relatively widely distributed outside Bolivia, I. schomburgkii Choisy and I. subrevoluta Choisy occurring in flooded pampas in Beni and Santa Cruz Departments and, outside Bolivia, extending to Venezuela and the Guayanas (Map 23). The third species I. hewittacea (Kuntze) J. R. I. Wood \& Scotland is widely distributed in Brazil and Bolivia but uncommon. The second group consists of 17 species of open cerrado habitats, all restricted to Bolivia and Brazil apart from I. argentea Meisn., which extends to Paraguay, Venezuela and Colombia, and the first five in the following list which also occur in Paraguay: I. hirsutissima Gardner, I. maurandioides Meisn., I. procumbens Mart. ex Choisy, I. procurrens Meisn., I. aprica House, I. caloneura Meisn., I. cerradoensis J. R. I. Wood \& Scotland, I. cuneifolia Meisn., I. goyazensis Gardner, I. graniticola J. R. I. Wood \& Scotland, I. haenkeana, I. paulistana (Silva Manso) Stellfeld, I. pinifolia Meisn., I. squamisepala O'Donell and I. virgata Meisn. To this should be added the endemic species, I. chiquitensis J. R. I. Wood \& Scotland. Within this group there are significant differences of habitat and distribution 
which are noteworthy. Four species (I. maurandioides, I. caloneura, I. graniticola and I. chiquitensis) are characteristic of rock outcrops (locally known as lajas) although the first two also occur in open cerrado (Map 8). I. hirsutissima is notably southern in its distribution being restricted to Chiquitos and German Busch provinces in Bolivia. I. haenkeana is also unusual as it is restricted to cerrado on lowland plain and is the only one of these species found west of the Río Grande in the cerrados of the Santa Cruz region (Map 9). Very remarkable is the concentration of this group of species around the PN Noel Kempff Mercado, where no less than 15 occur, six being restricted to the park itself (Map 9). Finally it should be noted that the distribution of I. cynanchifolia Meisn. loosely coincides with the cerrado biome although it is hardly typical of cerrado vegetation.

10. Some anomalous patterns. Not all species of Ipomoea found in Bolivia fit comfortably in one of the patterns above. Four species have disjunct distributions with Brazil but differ from each other in their Bolivian distribution. I. calyptrata Dammer and I. echinocalyx Meisn. are both rare species of central Brazil but, in Bolivia, the former is typical of very dry forest in the inter-Andean valleys while the latter grows in humid forest in the Andean foothills. In Brazil I. sericosepala J. R. I. Wood \& Scotland is apparently common in the cerrado and caatinga regions of Brazil whereas in Bolivia it is almost absent from the cerrados but locally common in the Serrano chaqueño and some inter-Andean dry valleys. $I$. indivisa (Vell.) Hallier f. is common in parts of southern Brazil and northeastern Argentina but in Bolivia is a rare species of the La Paz Yungas. I. incarnata (Vahl) Choisy is also interesting as it appears to be an indicator of very arid conditions being found in NE Brazil, the Guajira in Colombia, coastal Venezuela, the Galapogos Islands and coastal Peru. Its two stations in Bolivia are in particularly arid parts of the interAndean dry valley system.

\section{Endemism}

17 of the 102 species of Ipomoea recognised in this paper are endemic to Bolivia but this figure hides many distinct patterns of endemism. Nine species, I. chiquitensis, I. appendiculata, I. gypsophila, I. spinulifera, I. mendozae, I. odontophylla, I. huayllae, I. suburceolata O'Donell and I. tarijensis are pinpoint endemics restricted to a single locality or a few populations within a very strictly defined area (Map 10). All of these are Andean apart from I. chiquitensis. At least three species from eastern Bolivia (I. cardenasiana, I. graniticola and I. mucronatoproducta) are known from single localities in Bolivia but are not endemic to Bolivia as they also occur in neighbouring parts of Brazil where they are poorly known and apparently very rare. They are essentially endemic to the Pantanal region shared between Bolivia and Brazil. Of the remaining endemic species, some are rare I. psammophila and I. mucronifolia being restricted to two locations at the transition between the Cerrado and the Chaco, one (I. densibracteata) is relatively frequent in the same region, two (I. opulifolia, I. lactifera) are restricted to moist forest in the Andean foothills and adjacent plain and two, I. longibarbis and I. exserta, have a relatively wide distribution extending south from the Santa Cruz region towards the Argentinian border (Map 11). This region, loosely coinciding with the Serrano Chaqueño and Tucuman-Bolivian forest is especially rich in endemic species of Ipomoea if it is extended to include the northern extremities of Argentina. Besides these two relatively widespread species and five of the pinpoint endemics (I. appendiculata, I. gypsophila, I. spinulifera, I. tarijensis and I. mendozae), I. oranensis, I. schulziana and I. lilloana only just enter Argentina and are endemic to this zone, making it with 10 species far away the most important in terms of endemism.

\section{Phenology}

Details of the flowering period are given after each species where it is known. Many species have very distinct flowering seasons and plants are rarely found in flower outside this period. Among the more distinct patterns:

a. Annual species: these flower towards the end of the rainy season, typically from around February to May.

b. Most perennial species flower after the onset of significant summer rain usually from late December to around early April.

c. Cerrado species with a xylopodium often sprout and flower after the first rains in spring. This is the strategy of Ipomoea hirsutissima, I. argentea and I. cerradoensis. Some Chaco species (I. mucronifolia and I. psammophila) may follow a similar strategy. These species have often finished flowering by the end of December. Other cerrado species flower later but only for a brief period. I. caloneura and I. paulistana, for example, are at their best in January and are not usually found in flower before mid December or after February. Some other species have similar brief flowering periods, I. densibracteata flowers from early January to mid March and two of the rare endemic species from Tarija, I. tarijensis and I. gypsophila seem to flower from December to February only. In contrast, I. maurandiodes can be found in flower throughout the year.

d. Several moist forest species flower in the winter dry season notably Ipomoea regnellii, I. squamosa, I. ramosissima, I. lactifera and I. cryptica. These species are at their best in the July - August period. In contrast the archetypal moist forest species, I. philomega, flowers at the height of summer in the December - January period. 
The account that follows is essentially a taxonomic account of Ipomoea in Bolivia. It is hoped that users will be able to identify material by using the keys and illustrations before confirming their decision by checking the descriptions and accompanying notes. Information on distribution, ecology and flowering time are often invaluable aids to identification. This is provided in summary form, based on information from herbarium labels interpreted by the first author's field experience. It should be noted that some species are occasionally found in an unusual habitat for one reason or another or come into flower abnormally but this has sometimes been ignored in order to make the generalisations more meaningful.

\section{Ipomoea L.}

Annual or perennial herbs, subshrubs, shrubs, lianas or small trees, white latex sometimes present, habit various but most commonly twining or sprawling, frequently trailing, less often ascending or erect; rootstock varied but at least sometimes thickened and tuberous, unknown in many species; indumentum usually of simple eglandular hairs but occasionally branched, stellate or (very rarely) T-shaped in form. Leaves alternate, without stipules, most commonly petiolate, ovate with a truncate, cordate or sagittate base, less commonly and principally in the erect species sessile or shortly petiolate, oblong, obovate or linear with a cuneate or attenuate base. Inflorescence of usually pedunculate, axillary cymes borne in the axils of the upper leaves, the cymes often compounded with secondary and tertiary peduncles, sometimes corymbose or racemose in form, occasionally aggregated into terminal panicles, very occasionally arising on small axillary branchlets; bracteoles present but often caducous and inconspicuous; calyx of 5 free sepals, these similar or not, the outer two often similar and differing from the inner two with the middle sepal somewhat intermediate in form, inner sepals commonly with scarious margins; corolla very varied in colour and form but usually conspicuous and often open for a short time (morning or night only), commonly pink, less commonly blue, red, cream or white, commonly funnel-shaped and gradually widened with a broad spreading unlobed (sometimes weakly lobed) limb, less commonly campanulate, or crateriform with a cylindrical tube, more rarely suburceolate with the limb reduced to five teeth; stamens 5 unequal, two usually distinctly longer than the other three, inserted near the base of the tube, usually included, sometimes equal, exserted; filaments usually hairy at base, glabrous above, anthers linearoblong, pollen globose, echinulate; ovary bilocular (trilocular in a few species), style 1, stigma globose, sometimes clearly bi- or trilobed. Fruit a capsule, usually glabrous, 1 - 6-seeded but mostly 4-seeded, the style persistent or not on the ripening capsule; seeds very varied in indumentum, glabrous, minutely puberulent or tomentellous or conspicuously pilose or lanate, the longer hairs often restricted to the angles of the seeds.

There are various important caveats to be considered when using the following keys and descriptions:

It is not always easy to determine the habit of a particular species. Normally climbing species may be trailing in the absence of other vegetation. A few species may be erect, trailing or twining, Ipomoea paludicola for example, while its near relative, I. procurrens, might be interpreted as decumbent or scrambling. Several species are known to have swollen tuberous or woody rootstocks and it is likely that there may be diagnostic characters in the rootstock. However, roots are unknown in most species so of little value in species delimitation. It is not always easy to determine which species are annuals but as a rough guide annual species are commonly found in flower and fruit simultaneously whereas in the perennials fruits are usually only found after the flowers have fallen - this may be the explanation for why so many species have never been collected when in fruit. The term "bract" has been avoided as, in the majority of species, the leaves perform the function of bracts as they subtend the cymes. The term has been retained, however, in the erect species where the upper leaves which subtend the cymes are reduced in size and modified in shape so they appear different from the non-flower-bearing leaves. The term "bracteole" has been used for the usually small and often caducous paired structures which are present at the inflorescence branching points and base of the pedicel. No distinction is generally made between the bracteoles occurring at the primary, secondary or ultimate branching points, but it should be noted that the uppermost are more persistent than the lower. Many species have rounded, mucronate sepals, but the mucro is somewhat caducous so specimens are found where the apex appears muticous or even retuse while in less mature flowers the mucronate tip is still present. It should be noted that the sepals are often accrescent in fruit, especially in large-fruited species such as I. calyptrata or I. alba, where they often change shape as the plant matures, thus sepals lanceolate at anthesis are ovate in fruit, presumably as a result of the expansion of the ovary into the capsule. Measurements of the sepals have been taken from open flowers. Various considerations are relevant to the corolla. Whether the corolla is hirsute or glabrous on the exterior is an important diagnostic character and is most easily seen by examining the flower buds, as, on mature flowers the hairs are deciduous or difficult to see even with a hand lens. Corolla colour is a useful character but caution is required. Occasional albino flowers occur in normally pink-flowered species 
and in several species colour changes as the flowers age, blue commonly turning to pink. Several species appear always to have lobed corollas, I. argentea and I. parasitica, for example, but this character is difficult to see on dried specimens and, in any case, it is not certain how constant it is. Capsule and consequently seeds are unknown in many species so these characters cannot be used in many cases even though they are likely to be useful. It should be noted that hairs are sometimes deciduous on old seeds so seeds may appear glabrous when, in fact, they are pilose.

\section{Key to species of Ipomoea in Bolivia}

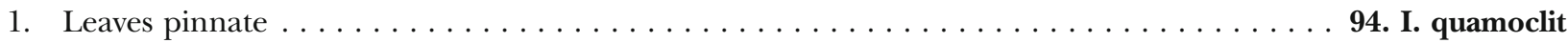

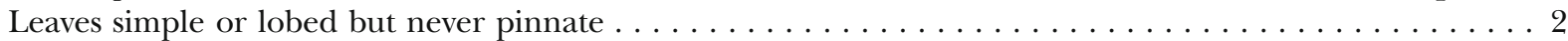

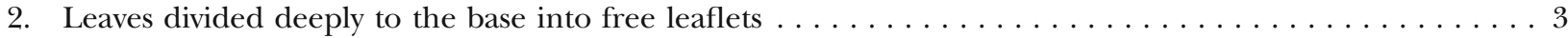
Leaves simple or lobed, but without free leaflets $\ldots \ldots \ldots \ldots \ldots \ldots \ldots \ldots$

3. Small, high altitude species with corm-like rootstock; sepals muricate. . . . . . . . . . . 100. I. plummerae Twining species at least $1 \mathrm{~m}$ high or long of middle or low altitudes; sepals smooth $\ldots \ldots \ldots$

4. Annual herb; corolla $<2.2 \mathrm{~cm}$ long; peduncles usually twisted or coiled. . . . . . . . . . . 101. I. wrightii Perennial herbs; corolla $>4 \mathrm{~cm}$ long; peduncles straight $\ldots \ldots \ldots \ldots \ldots \ldots$

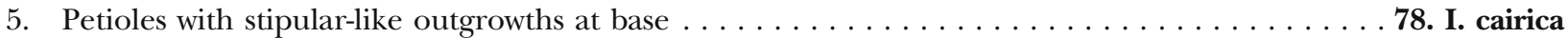

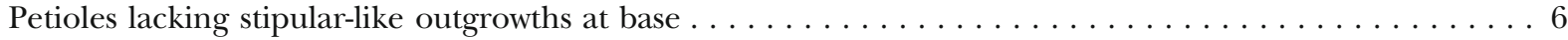

6. Sepals apiculate, $5-6 \mathrm{~mm}$ long; leaflets linear to narrowly oblong . . . . . . . . . . 102. I. subrevoluta

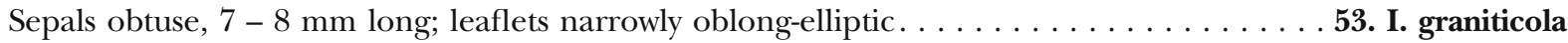

7. Leaves linear, oblong, oblanceolate, elliptic or (rarely) ovate with an attenuate to cuneate base; petioles very short $(<1 \mathrm{~cm}$ long) or absent; plants usually erect, sometimes decumbent, never climbing . . . . . . . 8 Leaves ovate to elliptic, cordate, truncate or rounded at base; petioles distinct, usually $>1 \mathrm{~cm}$ long; plants of

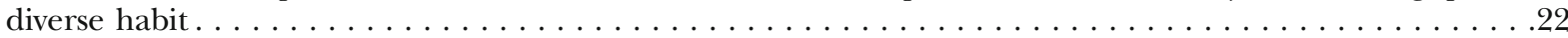

8. Small high altitude species with corm-like rootstock; leaves often bi- or trilobed; corolla $<3 \mathrm{~cm}$

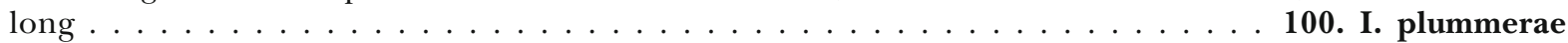
Lowland species of the cerrado biome (except I. mendozae); rootstock not corm-like; leaves never

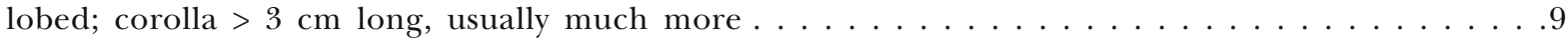

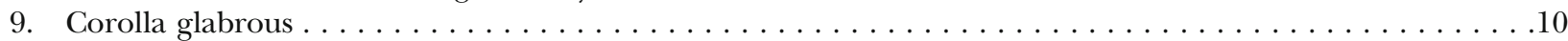

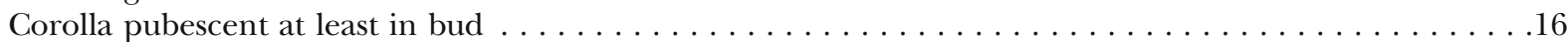

10. Outer sepals $>9 \mathrm{~mm}$ long; plant usually decumbent $\ldots \ldots \ldots \ldots \ldots \ldots \ldots$

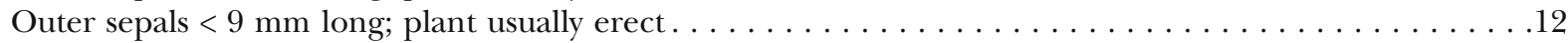

11. Sepals muricate; leaves commonly $>1.5 \mathrm{~cm}$ wide . . . . . . . . . . . . . . . . 12. I. procurrens Sepals smooth: leaves commonly $<1.5 \mathrm{~cm}$ wide $\ldots \ldots \ldots \ldots \ldots \ldots \ldots \ldots$. procumbens

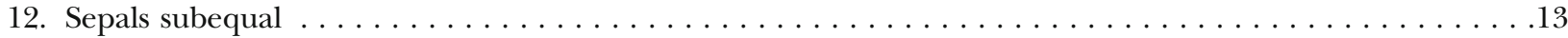

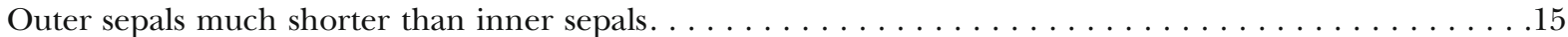


Leaves oblong, mostly $>3 \mathrm{~mm}$ wide; plant pubescent, tomentose or sericeous . . . . . . . . . . . 14

14. Leaves green, pubescent, imbricate, diminishing in size upward; corolla limb only weakly lobed ...58. I. paulistana Leaves silvery-tomentose or sericeous, not conspicuously imbricate, nor decreasing in size upwards; corolla limb

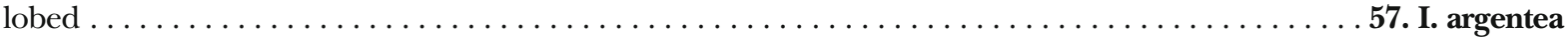

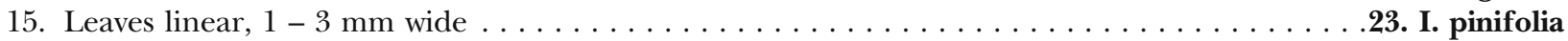



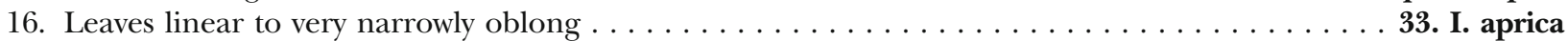
Leaves oblanceolate, obovate, elliptic or broadly oblong; if \pm ovate, then narrowed to a broadly cuneate base . . 17

17. Sepals $>12 \mathrm{~mm}$ long, finely acuminate; plant densely covered in stiff spreading hairs . . . . . . . 28. I. hirsutissima Sepals $<12 \mathrm{~mm}$ long, obtuse, sometimes mucronate but never finely acuminate; plant pubescent or softly grey

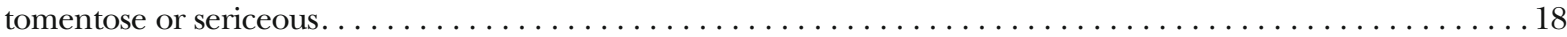

18. Leaves with petioles 0.5 - $2 \mathrm{~cm}$ long; decumbent plant of Vallegrande. . . . . . . . . . . 34. I. mendozae Leaves sessile or petioles $<0.5 \mathrm{~cm}$; erect cerrado plants $\ldots \ldots \ldots \ldots \ldots \ldots \ldots$

19. Inflorescence conspicuously branched, especially below; lower branches much exceeding subtending leaves . . . 20 Inflorescence simple or sparingly branched; cymes shorter than subtending leaves . . . . . . . . . . . . . . 21

20. Leaves oblong-obovate, abaxially grey-tomentose; sepals $7 \mathrm{~mm}$ long . . . . . . . . . . . . 30. I. haenkeana Leaves ovate to elliptic, abaxially white-floccose; sepals $8-12 \mathrm{~mm}$ long . . . . . . . . . . 31. I. virgata

21. Leaves oblong-oblanceolate; inflorescence terminal on stems . . . . . . . . . . . . . . 32. I. cuneifolia Leaves ovate to elliptic; corolla white; inflorescence axillary. . . . . . . . . . 29. I. cerradoensis 
22. Sepals with a prominent rigid awn (arista) nearly equalling the basal part of the sepal; corolla red, orange,

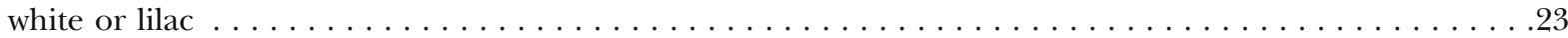
Sepals various, but if mucronate, mucro neither rigid nor nearly as long as the sepal; corolla usually pink,

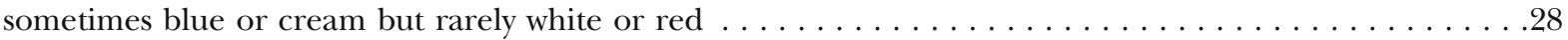

23. Corolla white or lilac, open at night or in cloudy conditions; awn $>5 \mathrm{~mm}$ long; stems commonly with fleshy

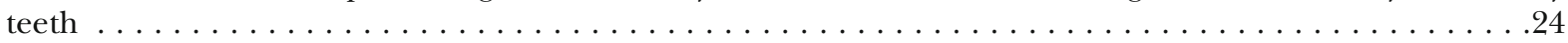
Corolla red or orange, open by day; awn $2-5 \mathrm{~mm}$ long; stems without fleshy teeth $\ldots \ldots \ldots \ldots \ldots 25$

24. Corolla white, narrowly cylindrical wth spreading limb, stamens exserted; outer sepals $15-25 \mathrm{~mm}$ long including awn $\ldots \ldots \ldots \ldots \ldots \ldots \ldots \ldots \ldots \ldots \ldots \ldots \ldots \ldots \ldots \ldots \ldots \ldots \ldots \ldots \ldots \ldots \ldots \ldots$. I. alba Corolla lilac, gradually widened above basal cylindrical tube, stamens included; outer sepals $10-14 \mathrm{~mm}$ long

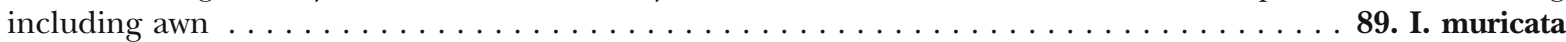

25. Corolla suburceolate, limb reduced to 5 tooth-like lobes $\ldots \ldots \ldots \ldots \ldots \ldots \ldots \ldots \ldots$ 93. I. lobata

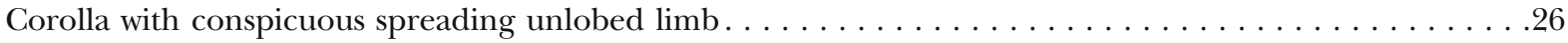

26. Outer sepals $1.5-3 \mathrm{~mm}$ long; fruiting capsule muticous, the style deciduous . . . . . . .95. I. hederifolia Outer sepals $3-4 \mathrm{~mm}$ long; fruiting capsule rostrate with a persistent style $\ldots \ldots \ldots \ldots \ldots \ldots \ldots .27$

27. Fruiting pedicels deflexed; leaves always unlobed $\ldots \ldots \ldots \ldots \ldots \ldots \ldots \ldots \ldots \ldots \ldots \ldots$ 97. I. indivisa Fruiting pedicels erect; leaves commonly lobed $\ldots \ldots \ldots \ldots \ldots \ldots \ldots \ldots \ldots \ldots \ldots$. I. rubriflora

28. Stem armed with numerous soft fleshy spines $\ldots \ldots \ldots \ldots \ldots \ldots \ldots \ldots \ldots \ldots \ldots \ldots \ldots \ldots$. I. setosa Stem without soft fleshy spines (a few usually present in $I$. parasitica $) \ldots \ldots \ldots \ldots \ldots \ldots \ldots \ldots \ldots \ldots \ldots \ldots \ldots \ldots$

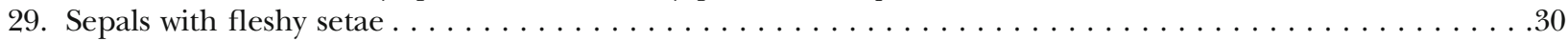

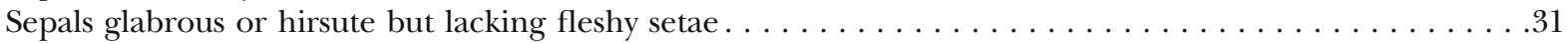

30. Outer sepals $15-25 \mathrm{~mm}$ long; leaves pubescent; peduncles $<0.5 \mathrm{~cm}$ long; corolla usually white or

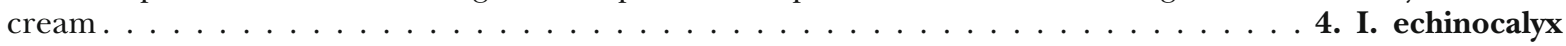
Outer sepals 12 - $14 \mathrm{~mm}$ long; leaves glabrous or puberulent; peduncles $0.5-8 \mathrm{~cm}$ long; corolla pink

3. I. crinicalyx

31. Outer sepals with a dorsal tooth-like appendage $\ldots \ldots \ldots \ldots \ldots \ldots \ldots \ldots \ldots \ldots \ldots \ldots \ldots$ 24. I. bahiensis

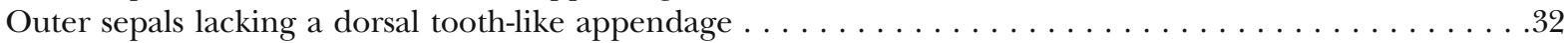

32. Sepals with $3-5$ raised, often dentate winged veins; bracteoles persistent $\ldots \ldots \ldots \ldots \ldots \ldots \ldots \ldots .33$

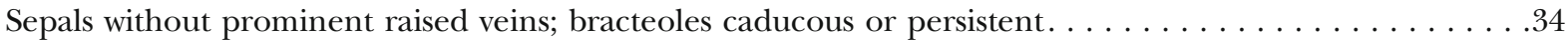

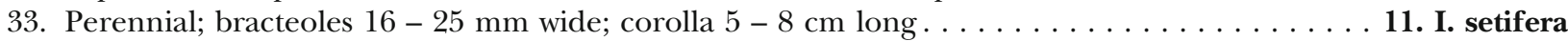

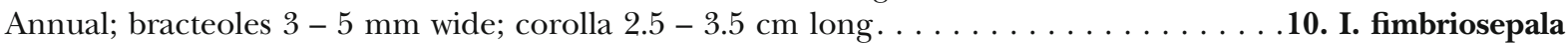

34. Sepals subequal, coriaceous, concave, usually obtuse and never distinctly acute or acuminate, usually glabrous but sometimes hirsute in lower half, $<11 \mathrm{~mm}$ long; corolla glabrous . . . . . . . . . . . . . . . 35 Sepals equal or unequal, at most weakly coriaceous, never concave: pubescent or glabrous, variable in length;

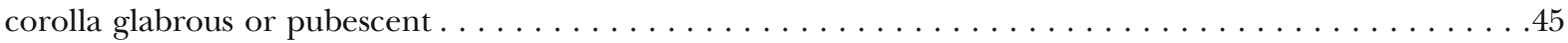

35. Indumentum of stellate hairs $\ldots \ldots \ldots \ldots \ldots \ldots \ldots \ldots \ldots \ldots \ldots \ldots \ldots \ldots \ldots \ldots \ldots \ldots \ldots$. I. bonariensis



36. Bracteoles large, foliose, concealing the calyx, persistent at least until fruit is formed . . 56. I. densibracteata

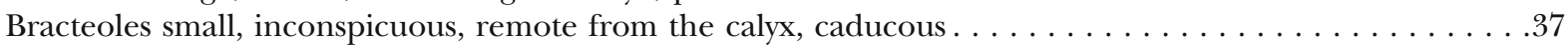

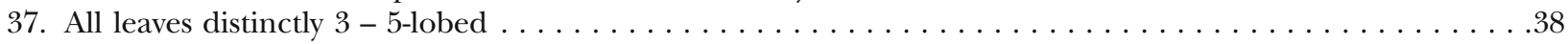
Leaves simple or with a few older leaves shallowly 3-lobed (occasionally leaves mostly absent at anthesis) . .....40

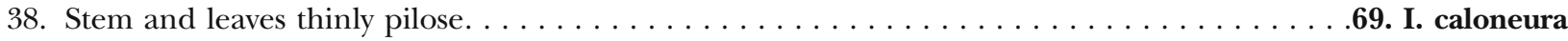

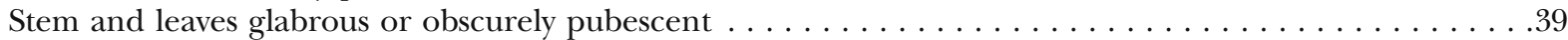

39. Leaves large, $5-14 \times 6-16 \mathrm{~cm}$; wetlands in tropical lowlands . . . . . . . mauritiana Leaves relatively small, mostly $4-6 \times 5-7 \mathrm{~cm}$; mostly dry habitats in the inter-Andean valleys and the

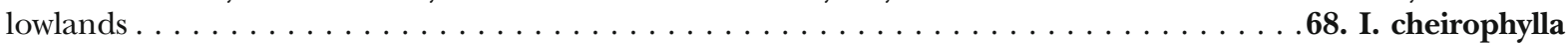


Plant densely pilose, the leaves grey-tomentose beneath, stellate hairs often mixed with simple hairs . . . .44

41. Corolla suburceolate, the limb reduced to 5 small teeth $\ldots \ldots \ldots \ldots \ldots \ldots \ldots \ldots$. $\ldots \ldots$ I. suburceolata

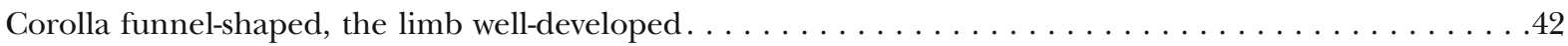

42. Leaf base truncate to weakly cordate or plant leafless when flowering $\ldots \ldots \ldots \ldots \ldots \ldots$ 62. I. schulziana

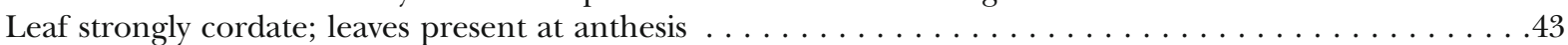

43. Peduncles and pedicels very short so flowers appear clustered in leaf axils; corolla tube white, the limb

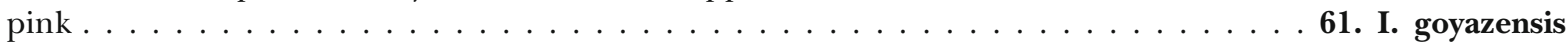
Peduncles mostly $>1.5 \mathrm{~cm}$ long so inflorescence lax; corolla uniformly pink or white on exterior . . .60. I. batatoides

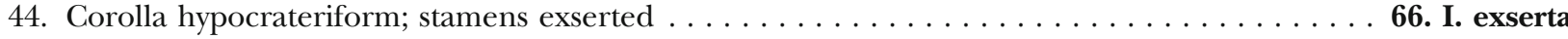
Corolla funnel-shaped; stamens included.

65. I. oranensis 
45. Corolla small, $<3 \mathrm{~cm}$ long; plant annual, rarely perennial, relatively slender $\ldots \ldots \ldots \ldots$ Corolla $>3 \mathrm{~cm}$ long, if slightly shorter, plant clearly perennial and very vigorous . . . . . . . . . 53

46. Sepals terminating in a fine hair point, hirsute or glabrous, lacking white margins; corolla pink. . . . . . .47 Sepals acute or obtuse but not terminating in a hair point, glabrous, the margin whitish; corolla pink or

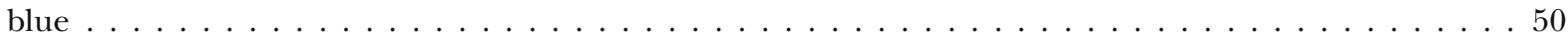

47. Outer sepals broadly oblong-elliptic, usually glabrous. $\ldots \ldots \ldots \ldots \ldots \ldots$

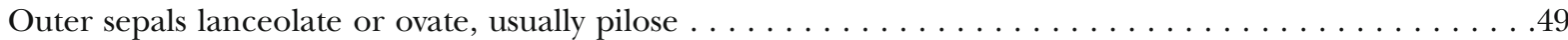

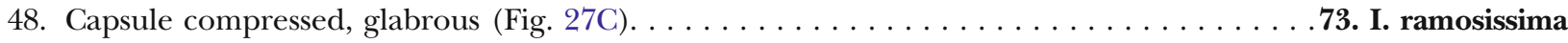

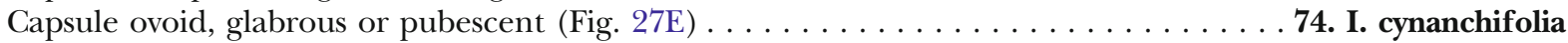

49. Ovary and capsule hirsute; sepals $9-11 \mathrm{~mm} \operatorname{long} \ldots \ldots \ldots \ldots \ldots \ldots \ldots$. . . . . . . . 72. I. grandifolia Ovary and capsule glabrous; sepals $5-6.5 \mathrm{~mm} \operatorname{long} \ldots \ldots \ldots \ldots \ldots \ldots \ldots \ldots$. . chiquitensis

50. Pedicels very short, $<5 \mathrm{~mm}$ long; seeds with abundant long hairs (lowland species) . . . . 26. I. acanthocarpa Pedicels $>5 \mathrm{~mm}$ long; seeds very shortly puberulent, often appearing glabrous $\ldots \ldots \ldots 1$

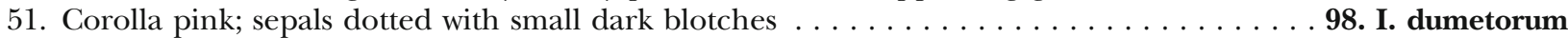
Corolla blue with a white tube; sepals not dotted with small dark blotches . . . . . . . . . . . . . .52

52. Peduncle usually passing through sinus of leaf base; sepals obtuse, verrucose, occasionally smooth ................................. aristolochiifolia Peduncle not passing through the sinus of leaf base; sepals acute, always smooth . . . . . . . 85. I. marginisepala

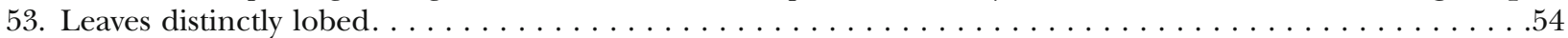

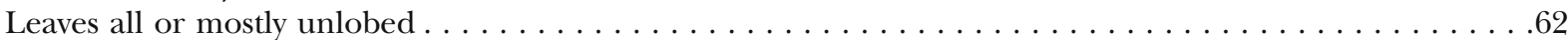



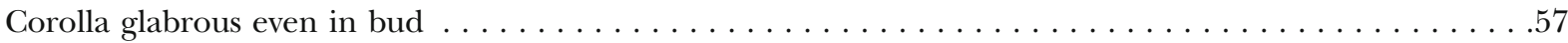

55. Leaf lobes gradually narrowed to a fine acuminate point; sepals and abaxial surface of leaves grey-

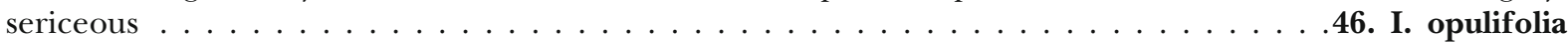
Leaf lobes rounded, mucronate or merely acute; sepals and leaves pubescent to pilose, not sericeous. .

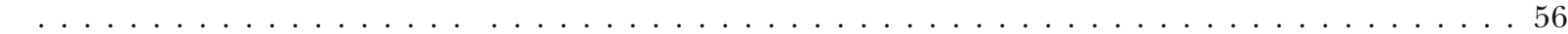

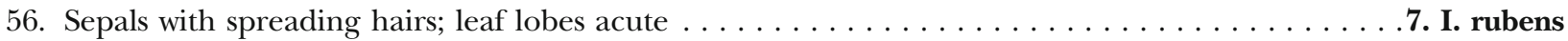
Sepals appressed-pilose; leaf lobes rounded and long-mucronate . . . . . . . . . . 35. I. mucronifolia

57. Sepals minutely puberulent, broad, obtuse; corolla pale pink . . . . . . . . . . . . 39. I. cardenasiana Sepals pubescent or pilose with spreading hairs, of varied shape; corolla blue, pink, violet or white but never pale

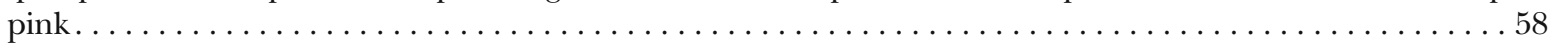

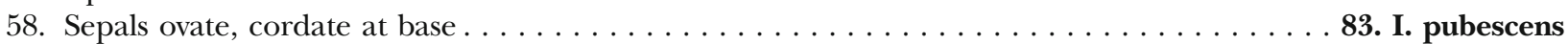
Sepals lanceolate or oblong-lanceolate, never cordate at base $\ldots \ldots \ldots \ldots \ldots$

59. Trailing plant, rooting at nodes; sepals prominently veined, terminating in a hair point. . . . .70. I. batatas Twining plant, not rooting at nodes; sepals neither prominently veined, nor terminating in a hair point . .60

60. Flowers arranged in a dense cluster, the pedicels $<7 \mathrm{~mm}$ long $\ldots \ldots \ldots \ldots$. indica Flowers in lax cymes, the pedicels up to $18 \mathrm{~mm}$ long. . . . . . . . . . . . . . . . . .61

61. Corolla pale blue; sepals 15 - $32 \mathrm{~mm}$, tapering to a long linear point, densely pilose, especially near base. . . . 82. I. nil Corolla usually pink, rarely white or blue; sepals $11-17 \mathrm{~mm}$, shortly acuminate to subobtuse, uniformly

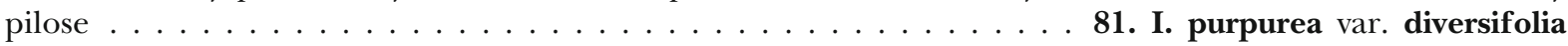

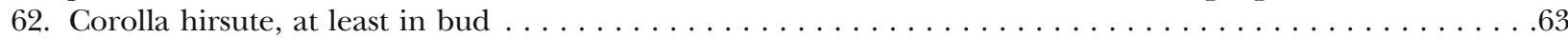

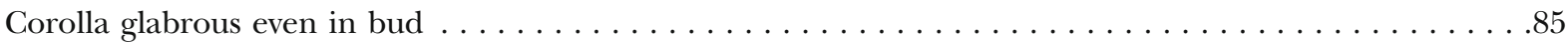

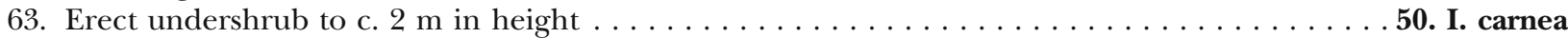

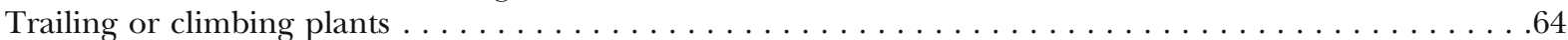

64. Bracteoles oblong-ovate or ovate, persistent, at least $5 \mathrm{~mm}$ wide. $\ldots \ldots \ldots \ldots$ Bracteoles linear or lanceolate, caducous or $<3 \mathrm{~m}$ wide $\ldots \ldots \ldots \ldots$

65. Bracteoles ovate, $7-24 \mathrm{~mm}$ wide, pale green with prominent dark veins forming an involucre round the

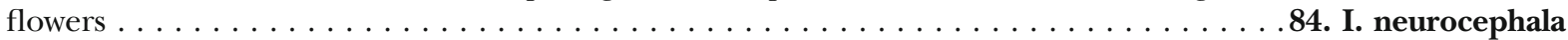
Bracteoles oblong-ovate, 5 - $13 \mathrm{~mm}$ wide, dull green without prominent veins . . . . . . . 14. I. amazonica

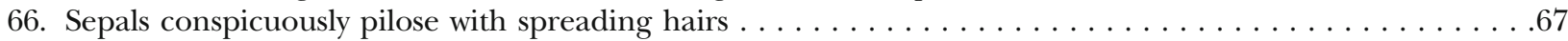
Sepals puberulent, pubescent or tomentose but not with conspicuous spreading hairs $\ldots \ldots \ldots$

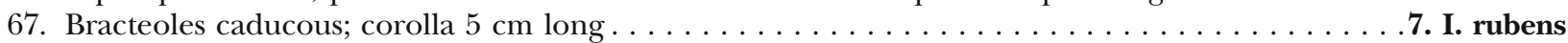

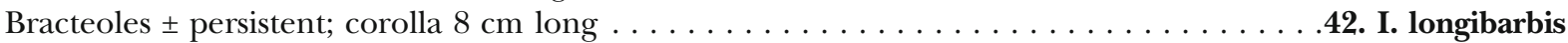

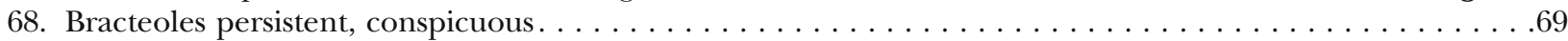



69. Leaves densely grey-tomentose abaxially; bracteoles linear or oblanceolate . . . . . . . . . . . . . . . 70 Leaves thinly pubescent on both surfaces; bracteoles lanceolate. 


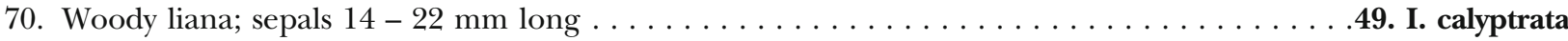

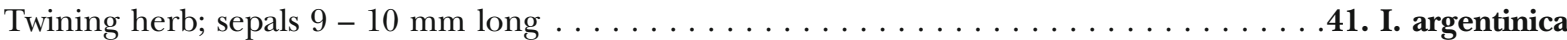

71. Leaves (white-) grey-tomentose at least on the lower surface . . . . . . . . . . . . . . . . . . . .72 Leaves glabrous to pubescent on the lower surface $\ldots \ldots \ldots \ldots \ldots \ldots \ldots$

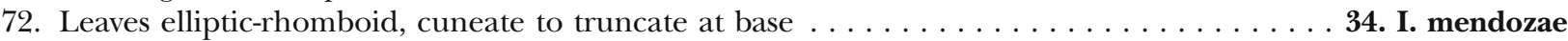

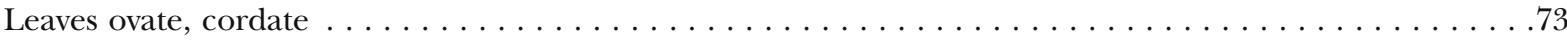

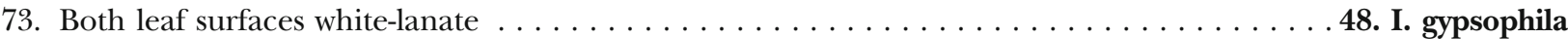
Upper leaf surface greenish, lower surface grey or white tomentose $\ldots \ldots \ldots \ldots \ldots \ldots$

74. Sepals glabrous or near-glabrous .

9. I. abutiloides

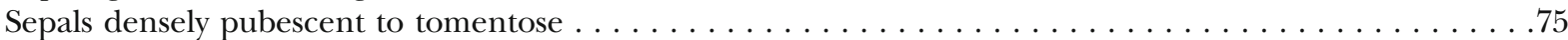

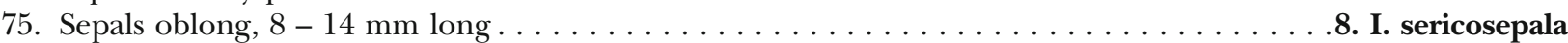
Sepals ovate, $9-11 \mathrm{~mm}$ long $\ldots \ldots \ldots \ldots \ldots \ldots \ldots \ldots \ldots \ldots \ldots$. . . hieronymi

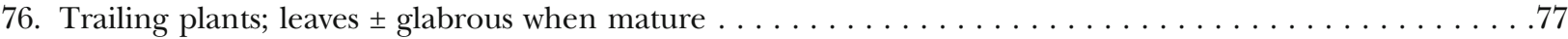
Twining/climbing plants; leaves glabrous or hairy at maturity $\ldots \ldots \ldots \ldots \ldots$

77. Seeds woolly; leaves dark green, undulate. Inter-Andean valleys

37. I. lilloana Seeds glabrous; leaves green, entire. Cerrado/Chaco transition

78. Sepals with a prominent swollen appendage; leaves glabrous 43. I. appendiculata

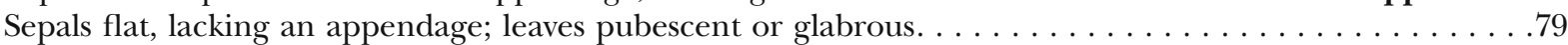

79. Sepals very unequal, lanceolate, $7-17 \mathrm{~mm} \operatorname{long} \ldots \ldots \ldots \ldots \ldots$ Sepals subequal, ovate or elliptic, $5-12 \mathrm{~mm}$ long $\ldots \ldots \ldots \ldots \ldots$

80. Inner sepals $9-12 \mathrm{~mm}$ long, longer than outer sepals; peduncles $1-5.5 \mathrm{~cm}$ long $\ldots \ldots \ldots$. . .5. I. regnellii Outer sepals $12-17 \mathrm{~mm}$ long, longer than the inner sepals; cymes long-pedunculate, peduncles $8-30 \mathrm{~cm}$ $\operatorname{long} \ldots \ldots \ldots \ldots \ldots \ldots \ldots \ldots \ldots \ldots \ldots \ldots \ldots \ldots \ldots \ldots \ldots$. magnifolia

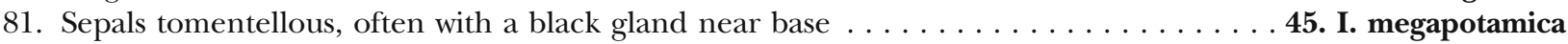
Sepals pubescent (sometimes thinly so) without a black gland near base $\ldots \ldots \ldots \ldots$

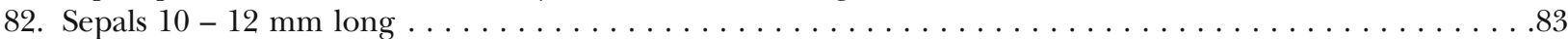



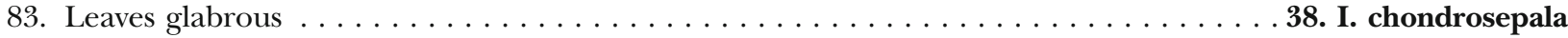
Leaves pilose on abaxial veins $\ldots \ldots \ldots \ldots \ldots \ldots \ldots \ldots \ldots \ldots \ldots \ldots \ldots \ldots \ldots \ldots \ldots \ldots$. . . 47. I. spinulifera

84. Sepals with white margins; corolla white, sometimes with pink centre, unlobed; stem with corky bark, lacking

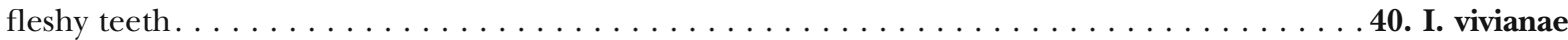
Sepals lacking white margins; corolla bluish with a white tube, lobed; stem often with fleshy teeth, never with

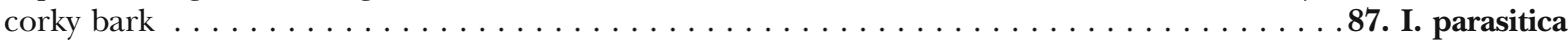

85. Sepals conspicuously unequal, the outer much shorter than the inner $\ldots \ldots \ldots$

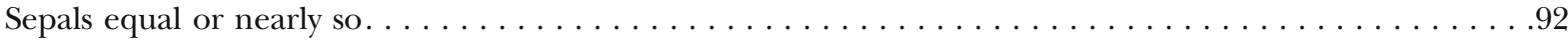

86. Sepals thinly to densely pilose; creeping perennial rooting at nodes, cultivated or escaped. . . .70. I. batatas

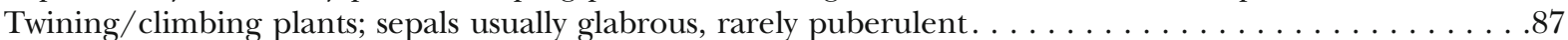

87. Sepals all $10 \mathrm{~mm}$ or less; cymes many-flowered $\ldots \ldots \ldots \ldots \ldots \ldots$ Some sepals more than $10 \mathrm{~mm}$ long; cymes 1 - 3-flowered; flowers often solitary . . . . . . . . . .90

88. Sepals lacking white margins; corolla $3-4 \mathrm{~cm}$ long.

75. I. lactifera Sepals with distinct white margins; corolla $4-7 \mathrm{~cm}$ long $\ldots \ldots \ldots \ldots \ldots$

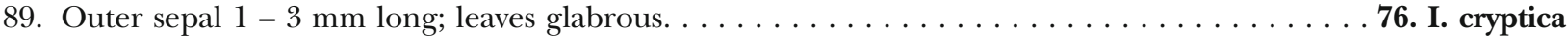

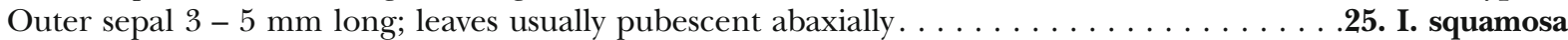

90. Corolla lobes terminating in a prominent mucro up to $5 \mathrm{~mm}$ long; all sepals $>10 \mathrm{~mm}$ long ... 21. I. mucronatoproducta Corolla lobes not terminating in a prominent mucro; shorter sepals $<9 \mathrm{~mm}$ long $\ldots \ldots \ldots 1$

91. Large-leaved plant of flooded pampa; outer sepals often muricate; corolla $7-8.5 \mathrm{~cm}$ long . . . . 13. I. paludicola Small-leaved plant of rock outcrops and dry cerrado; outer sepals smooth; corolla $4-6 \mathrm{~cm}$ long . . . 19. I. maurandioides

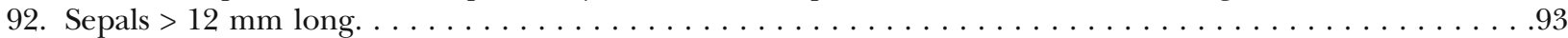

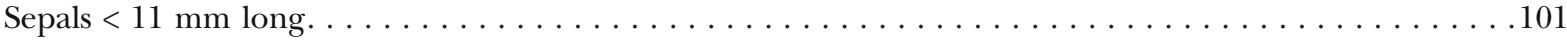

93. Flowers in clusters with persistent linear bracteoles $\ldots \ldots \ldots \ldots \ldots \ldots \ldots \ldots \ldots$. . . . . . . . . 8 . . . . . .



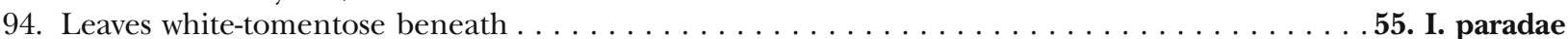
Leaves glabrous or pubescent, but not white-tomentose beneath $\ldots \ldots \ldots \ldots$

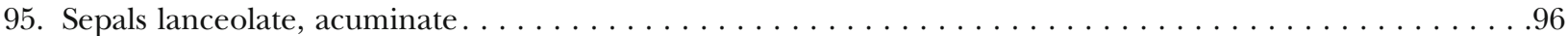

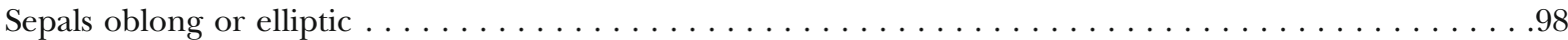

96. Sepals pubescent.

79. I. magnifolia 


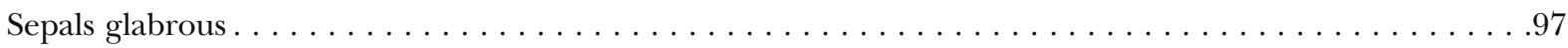

97. Plant completely glabrous; sepals prominently veined, $17-21 \mathrm{~mm}$ long; corolla pink (very dry inter-Andean valleys $\ldots \ldots \ldots \ldots \ldots \ldots \ldots \ldots \ldots \ldots \ldots \ldots \ldots \ldots \ldots \ldots \ldots \ldots \ldots \ldots \ldots$. incarnata Stem usually pilose with long hairs; sepals not prominently veined, 23 - $28 \mathrm{~mm}$ long; corolla blue. .. .2. I. clavata

98. Corolla cream or white or cream with dark centre $\ldots \ldots \ldots \ldots \ldots \ldots \ldots \ldots \ldots \ldots \ldots \ldots \ldots$

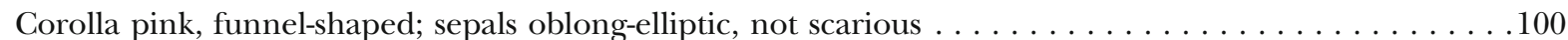

99. Corolla campanulate; liana without copious white latex; leafy when flowering . . . . . . . 1. I. corymbosa Corolla funnel-shaped; small tree or subshrub with copious white latex, usualy leafless when

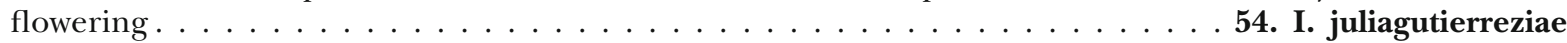

100. Sepals $10-14 \mathrm{~mm}$ wide, commonly reddish-brown; corolla $5-6 \mathrm{~cm}$, glabrous; inflorescence commonly much-

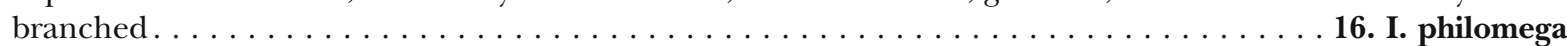
Sepals $7-8 \mathrm{~mm}$ wide, greenish; corolla $7-9.5 \mathrm{~cm}$, often pubescent in bud; inflorescence not markedly branched . . . . . . . . . . . . . . . . . . . . . . . . . . . . . 38. I. chondrosepala

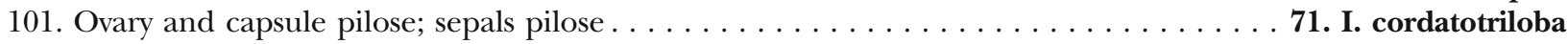
Ovary and capsule glabrous; sepals glabrous or very shortly pubescent $\ldots \ldots \ldots \ldots \ldots \ldots \ldots \ldots 2$

102. Corolla cream with a dark centre; inflorescence commonly developing into a paniculate or racemose

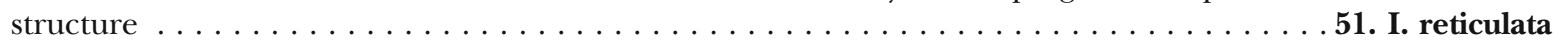



103. Leaves dentate (Yungas de Mairana) $\ldots \ldots \ldots \ldots \ldots \ldots \ldots \ldots \ldots \ldots \ldots \ldots \ldots \ldots \ldots \ldots$. I. odontophylla



104. Sepals lanceolate, acute, glabrous; corolla with a blue $\operatorname{limb} \ldots \ldots \ldots \ldots \ldots \ldots \ldots \ldots \ldots \ldots \ldots \ldots$ Ovate to oblong-elliptic, never acute; glabrous, puberulent or pubescent; corolla blue or pink . . . .. 106



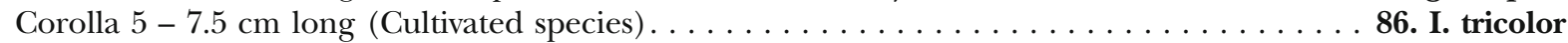

106. Corolla blue; sepals with spreading hairs; peduncle passing through sinus of leaf base (Yungas) ... . 92. I. huayllae Corolla pink; sepals glabrous or with appressed hairs; peduncle not passing through leaf sinus . . . . . 107

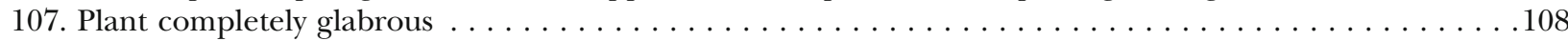

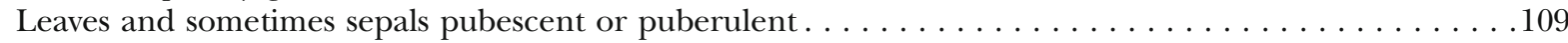

108. Corolla $2-3 \mathrm{~cm}$ long; inner sepals $5-5.5 \mathrm{~mm}$ long $\ldots \ldots \ldots \ldots \ldots \ldots \ldots \ldots \ldots \ldots \ldots \ldots$ 18. I. amnicola

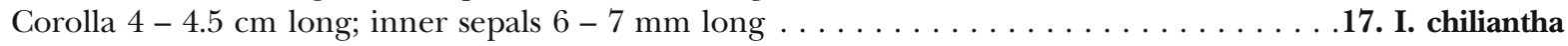

109. Stamens c. $2.5 \mathrm{~cm}$ long; leaf auricles overlapping; pedicels scurfy-puberulent; plant decumbent . . . . 52. I. tarijensis Stamens $4-5 \mathrm{~cm}$ long; leaf auricles not overlapping; pedicels pubescent; plant usually climbing . . . . .99. I. jujuyensis

\section{Supplementary keys using specific characters}

These keys provide lists of species under specific characters which may facilitate identification.

1. Monophyletic, morphologically diagnosable groups:

a. Chaco radiation group: perennials of varied habit; plant usually hairy; sepals subequal, hirsute (sometimes obscurely so); corolla hirsute in bud; seeds pilose: Species 28-48 (Ipomoea rubens, I. sericosepala, I. calyptrata and some other species might appear superficially to belong).

b. Coriaceous sepal group: perennials of varied habit; sepals subequal, coriaceous, concave, usually glabrous, occasionally hirsute near base; corolla glabrous; seeds pilose. Species $57-70$ (Ipomoea amnicola, I. chiliantha and I. reticulata might also be interpreted as having coriaceous sepals).

c. Batatas group: annual or perennial creeping or twining plants; sepals thin or papery in texture, mucronate to aristate; corolla glabrous often with dark centre; ovary and capsule glabrous or hirsute; seeds obscurely tomentellous. Species $70-75$. (Ipomoea amnicola, I. chiliantha and I cryptica might be mistakenly placed here).

d. Pharbitis group; annual or perennial twining herbs; bracteoles relatively persistent, similar in texture to sepals; stigma 3-lobed, capsule up to 6-seeded, seeds very shortly tomentellous, often appearing glabrous. Species $79-84$.

e. Quamoclit group; mostly annual twining herbs; leaves simple, lobed or pinnate; sepals with conspicuous awn; corolla red or orange, hypocrateriform or suburceolate; seeds tomentellous. Species $93-97$.

\section{Habit and indumentum.}

a. Woody lianas: I. corymbosa, I. calyptrata, I. juliagutierreziae, I. philomega and, less obviously, I. abutiloides, I. sericosepala.

b. Stem (and leaves) with stellate hairs: I. bonariensis, I. oranensis, I. exserta. 
c. Stems with long spreading hairs: I. clavata, I. hirsutissima, I. mucronifolia, I. mendozae, I. nil, I. pubescens.

d. Stems with fleshy spines: I. setosa, I. alba, I. muricata, I. parasitica.

e. Stems with minute hard spinules: I. spinulifera.

f. Stems corky: I. vivianae.

g. Erect perennials: I. procurrens (sometimes), I. paludicola (sometimes), I. pinifolia, I. squamisepala, I. hirsutissima, I. cerradoensis, I. haenkeana, I. virgata, I. cuneifolia, I. aprica, I. carnea subsp. fistulosa, I. argentea, I. schomburgkii, I. paulistana, I. bonariensis var. erecta.

h. Usually trailing perennials: I. maurandioides, I. paludicola, I. procumbens, I. psammophila, I. lilloana, I. mucronifolia, I. mendozae, I. gypsophila, I. plummerae, I. batatas.

i. Probable annuals usually found with capsules: I. fimbriosepala, I. chiquitensis (?), I. cordatotriloba, I. grandifolia, I. ramosissima, I. cynanchifolia, I. marginisepala, I. tricolor, I. purpurea, I. nil, I. neurocephala, I. aristolochiifolia, I. lobata, I. quamoclit, I. hederifolia, I. rubriflora, I. indivisa, I. dumetorum, I. wrightii.

\section{Leaves}

a. Leaves pinnate: I. quamoclit

b. Leaves linear, oblong or obovate, basally cuneate: I. procumbens, I. pinifolia, I. squamisepala, I. haenkeana, I. virgata, I. cuneifolia, I. aprica, I. argentea, I. schomburgkii, I. paulistana.

c. Leaves divided into free leaflets: I. graniticola, I. plummerae, I. cairica, I. wrightii, I. subrevoluta.

d. Leaves lobed: I. rubens (sometimes), I. cardenasiana (3lobed), I. opulifolia (3-lobed), I. mauritiana (usually 5lobed), I. cheirophylla (usually 5-lobed), I. caloneura, I. bonariensis (uncommonly), I. oranensis (rarely), I. batatas, I. cordatotriloba, I. grandifolia, I. ramosissima (rarely), I. cynanchifolia (rarely), I. indica (sometimes), I. nil (mostly shallowly 5-lobed), I. purpurea var. diversifolia, I. pubescens (mostly 5-lobed), I. hederifolia (shallowly lobed), I. rubriflora (shallowly lobed), I. lobata ( 2 - 3-lobed), plummerae forma adiantifolia.

e. Leaves white-felted on one or both surfaces: I. abutiloides, I. sericosepala, I. argentinica, I. cairica (sometimes), I. longibarbis, I. hieronymi, I. opulifolia, I. gypsophila, I. calyptrata, I. paradae, I. argentea, I. indica (rarely).

f. Leaves markedly sagittate/hastate: I. paludicola, I. maurandioides, I. mucronatoproducta, I. incarnata, I. bahiensis

g. Petioles with basal stipule-like structures: $I$. cairica, I. quamoclit.

\section{Inflorescence characters}

a. Peduncles very short: I. goyazensis, some erect species. b. Bracteoles very persistent: I. fimbriosepala, I. setifera, I. amazonica, I. hewittacea, I. argentinica, I. calyptrata, I. densibracteata, species $79-84$ especially I. neurocephala.

c. Sepals muricate or dentate: I. procurrens, I. paludicola, I. fimbriosepala, I. setifera, I. aristolochiifolia, I. plummerae.

d. Outer sepals conspicuously shorter than inner: I. paludicola, I. maurandioides, I. mucronatoproducta, I. pinifolia, I. squamisepala, I. squamosa, I. cryptica.

e. Sepals with appendages or large glands: I. bahiensis, I. appendiculata, I. megapotamica, I. hieronymi.

f. Sepals with soft spines: I. crinicalyx, I. echinocalyx, (I. setosa outside Bolivia).

g. Sepals oblong or oblong-elliptic, relatively long, obtuse: I. corymbosa, I. sericosepala, I. abutiloides, I. philomega, I. cardenasiana, I. chondrosepala, I. calyptrata, I. paradae, I. juliagutierreziae.

h. Sepals lanceolate or ovate, acuminate; I. clavata, I. incarnata, I. mucronatoproducta, I. mucronifolia, I. magnifolia, I. indica, I. nil.

i. Sepals with spreading hairs: I. rubens, I. hirsutissima, I. mucronifolia, I. mendozae, I. longibarbis, I. purpurea, I. nil, I. pubescens.

j. Sepals cordate: I. pubescens.

\section{Corolla characters}

a. Corolla white or cream with/without dark or reddish centre: (albino flowers occasionally occur in other species such as I. bahiensis and I. batatoides): I. alba, I. cerradoensis, I. virgata, I. echinocalyx, I. corymbosa, I. reticulata, I. paradae, I. juliagutierreziae, I. lactifera.

b. Corolla red or orange: I. suburceolata, species 93-97.

c. Corolla blue/lilac: I. clavata, I. marginisepala, I. tricolor, I. parasitica, I. muricata, I. indica, I. nil, I. aristolochiifolia, I. odontophylla, I. huayllae.

d. Corolla suburceolate: I. lobata, I. suburceolata.

e. Corolla deeply lobed: I. argentea, I. parasítica, I. quamoclit.

f. Corolla very small ( $<2.5 \mathrm{~cm}$ long): I. chiquitensis, I. cynanchifolia, I. grandifolia, I. ramosissima, I. dumetorum, I. aristolochiifolia, I. wrightii.

g. Corolla tube white (strongly contrasting with coloured limb): I. goyazensis, I. tricolor, I. marginsepala, I. parasitica.

h. Stamens exserted: I. suburceolata, I. exserta, species $93-$ 97 (nearly exserted in I. reticulata and I. tarijensis).

\section{Fruit characters}

Capsule and ovary hirsute: I. batatas, I. cordatotriloba, I. grandifolia, I. cynanchifolia.

Capsule held on a recurved (deflexed) pedicel: I. parasitica, I. indivisa, I. dumetorum, I. jujuyensis.

\section{Habitat}

a. Species of lowland wetlands: I. alba (often partially shaded places), I. amnicola, I. carnea, I. chiliantha, 
I. hewittacea (cerrado biome), I. mauritiana, I. paludicola (flooded pampa), I. rubens (rivers and lakes), I. schomburgkii (flooded pampa), I. setifera, I. subrevoluta (flowing streams).

b. Species of lowland rock outcrops: I. bonariensis, I. caloneura, I. chiquitensis, I. graniticola, I. maurandioides, I. sericosepala.

c. Species of cerrado: Ipomoea aprica, I. caloneura,

I. cerradoensis, I. goyazensis, I. haenkeana,

I. hewittacea, I. hirsutissima, I. maurandioides,

I. mucronatoproducta, I. paulistana, I. procumbens,

I. procurrens, I. psammophila, I. virgata.

d. Species of Chiquitano dry forest: Ipomoea abutiloides, I. hederifolia, I. ramosissima, I. reticulata.

e. Species of humid lowland forest: Ipomoea batatoides, I. cryptica, I. hederifolia, I. philomega, I. ramosissima, I. regnellii, I. reticulata, I. squamosa, I. lactifera.

f. Species of the Yungas valleys: I. alba, I. amnicola, I. aristolochiifolia, I. batatoides, I. clavata, I. dumetorum, I. echinocalyx, I. hederifolia, I. huayllae, I. indivisa, I. jujuyensis, I. magnifolia, I. nil, I. opulifolia,

I. ramosissima, I. squamosa, I. suburceolata.

g. Species of the Inter-Andean dry valleys (excluding Tarija): Ipomoea amnicola, I. aristolochiifolia, I. cheirophylla, I. dumetorum, I. lilloana, I. marginisepala, I. mendozae, I. nil, I. oranensis, I. purpurea, I. rubriflora, I. schulziana, I. sericosepala, I. juliagutierreziae.

h. Species restricted to Inter-Andean valleys in Tarija Department additional to above: I. appendiculata, I. gypsophila, I. hieronymi, I. spinulifera, I. tarijensis.

i. Species very common around Santa Cruz extending into the Andes and the Chiquitania: I. abutiloides, I. alba, I. amnicola, I. argentinica, I. chondrosepala, I. cordatotriloba, I. corymbosa, I. hederifolia, I. nil, I. ramosissima, I. regnellii, I. reticulata, I. cairica.

j. Chaco species: I. amnicola, I. bonariensis, I. crinicalyx, I. longibarbis, I. schulziana, I. sericosepala, I. vivianae, I. wrightii.

k. Weeds found around settlements: I. batatas, I. cairica, I. cordatotriloba, I. dumetorum, I. grandifolia, I. nil, I. parasitica, I. purpurea, I. quamoclit, I. ramosissima.

1. Cultivated species: Ipomoea alba, I. batatas, I. cairica, I. carnea, I. indica, I. lobata, I. purpurea, I. quamoclit, I. tricolor.

The linear sequence in which the species are ordered reflects phylogenetic relationships where possible (Williams et al. in prep.). Clades that comprise species that are collectively diagnosable are indicated at appropriate intervals in the following sequence and as these clades often comprise an unresolved polytomy the order of species within the clades is more or less arbitrary, albeit with similar species placed together. Basionyms and commonly used synonyms are cited throughout. Long disused synonyms such as some of the names in Foster (1958) have not been cited as they are listed in Jorgensen et al. (2015) and many were, in fact, misapplied anyway. When we have deviated from decisions in Austin \& Huáman (1996), this has been indicated both in the few examples of species listed for Bolivia which we have not been able to trace and when we have identified names which were not accounted for in that list.

Slightly fuller descriptions are provided of the new species. It should be noted that some details may be absent. In several cases the fruit is unknown. In a few cases it has been judged unwise to dissect the corolla in dried specimens so the style and filaments cannot be reliably described. The corolla is fragile and in none of the specimens of Ipomoea gypsophila was there more than a single corolla and this pasted to the sheet. Unsurprisingly herbarium curators are reluctant to permit the destruction of the only corolla in these circumstances. In a few cases no stigma could be found in a damaged corolla as in the case of I. huayllae.

In the comments that follow the descriptions, the abbreviations TCO, PN and ANMI refer respectively to Tierra Comunitaria de Origen, Parque Nacional (National Park) and Area Natural de Manejo Integrado, a protected area lacking the high degree of protection afforded to a national park. Where selected specimens are cited, at least one has been cited for each province where it occurs. Conservation assessments have been made following IUCN (2012) guidelines using GEOCAT but have not been applied mechanically. The reality is that most species fall into one of two categories: Least Concern (LC) or Data Deficient (DD). Large areas of Bolivia are poorly studied botanically and any species with two or three widely scattered records is likely to occur, perhaps frequently, in areas lying between known locations (see Map 6 of Ipomoea philomega for an example). Only in the case of localised species from a well-studied area can we be reasonably certain of the total distribution and conservation status of a species. Annual species are particularly difficult to assess. Species such as I. neurocephala, I. fimbriosepala and I. wrightii are impermanent, often overlooked and their real status uncertain. Several species are known only or mainly from the Noel Kempff Park. This area covers three quarters of a million hectares, is difficult of access and poorly explored botanically. There are few records of individual Ipomoea species and single records give no indication of the real frequency of the species. All benefit from both the protection of the law and the inaccessibility of the park. They all also occur in some frequency in Brazil.

1. Ipomoea corymbosa (L.) Roth ex Roem. EF Schult. (Roemer \& Schultes 1819: 232). 
Convolvulus corymbosa L. (Linnaeus 1759: 923). Type: Burman, Pl. Amer. Plum. T. 89 f. 2, lectotype, designated by Stearn (1974: $7 \mathrm{ff}$.).

Turbina corymbosa (L.) Raf. (Rafinesque 1838: 81).

Liana climbing to about $7 \mathrm{~m}$ over shrubs and small trees; stems woody, usually glabrous. Leaves petiolate, $4-10 \times 3-9 \mathrm{~cm}$, ovate, cordate with rounded auricles, narrowed to an obtuse, shortly mucronate apex, glabrous or (rarely) pubescent, abaxially paler; petioles $2-5 \mathrm{~cm}$. Inflorescence of lax compound cymes terminal on the main stem and on lateral branchlets $5-20 \mathrm{~cm}$ long; secondary peduncles $1-5 \mathrm{~cm}$, bracteoles c. $2 \mathrm{~mm}$, scale-like; pedicels $7-17 \mathrm{~mm}$, sepals slightly unequal, oblong, obtuse, nearly completely scarious, glabrous, outer $10-11 \mathrm{~mm}$, inner $11-14 \mathrm{~mm}$; corolla $2.5-3 \mathrm{~cm}$, campanulate, cream with dark centre and yellow midpetaline bands, glabrous, limb c. $1.5-2 \mathrm{~cm}$ diam. Capsule narrowly ovoid, $11-14 \times 3-4 \mathrm{~mm}$, glabrous, style persistent, seeds $1-2,4-5 \mathrm{~mm}$ diam., subglobose, tomentose. Fig. 1A.

DISTRIBUTION \& HABITAT. Widespread throughout tropical America and introduced into the Old World, this species is of uncertain status in Bolivia. It is locally frequent in disturbed bushy places usually near settlements in the moister lowlands below about $1100 \mathrm{~m}$, principally but not exclusively in the Santa Cruz region. It is particularly common in riverine scrub. Map 1.

SELECTED SPECIMENS OF 25 EXAMINED. BOLIVIA. Beni: Prov. Ballivian, Est. Biologica del Beni, Com. Totizal, $14^{\circ} 30^{\prime} \mathrm{S} 66^{\circ} 37^{\prime} \mathrm{W}, 200$ m, 8 May 1995, J. Balderrama 417 (USZ). Cochabamba: Prov. Carrasco, Valle de Sajta, 23 May 1989, Naessaeny 67 (LPB). La Paz: Prov. Tamayo, ANMI Madidi, $21 \mathrm{~km} \mathrm{~N}$ of Apolo, 14 $32^{\circ} 26^{\prime \prime S}$ 68 29'46"W, 1022 m, 4 Sept. 2004 (fr), L. Cayola et al. 886 (LPB, MA, MO, USZ). Santa Cruz: Prov. Cordillera, Gutiérrez, $22 \mathrm{~km} \mathrm{~N}$ of San Juan de Palmotellas, $17^{\circ} 09^{\prime} 58^{\prime \prime S} 63^{\circ} 20^{\prime} 27^{\prime \prime W}, 20$ July 2003, M. S. Ferrucci et al. 1828 (CTES, USZ). Prov. Florida, carretera entre Bermejo y Cuevas, $18^{\circ} 08^{\prime} \mathrm{S} 63^{\circ} 43^{\prime} \mathrm{W}$, 1400 m, 8 June 2008, J. R. I. Wood 25054 (K, LPB, USZ). Prov. Ibañez, Porongo, camino de Agua Dulce a Surutu, $17^{\circ} 48^{\prime}-52^{\prime} \mathrm{S}, 63^{\circ} 27^{\prime}-28^{\prime} \mathrm{W}, 500-650$ m, 23 July 2007, I. Linneo 1161 (MO, OXF, USZ). Prov. Ñuflo de Chávez, c. $15 \mathrm{~km}$ from Concepción along road to San Javier, 16 ${ }^{\circ} 10^{\prime} 23^{\prime \prime S} 62^{\circ} 08^{\prime} 39^{\prime \prime} \mathrm{W}, 25$ July 2014, J. R. I. Wood E D. Soto 27940 (LPB, OXF, USZ). Prov. Santiesteban, $15 \mathrm{~km} \mathrm{~N}$ of Mineros, E of Río Chané, $16^{\circ} 59^{\prime} \mathrm{S} 63^{\circ} 12^{\prime} \mathrm{W}, 225 \mathrm{~m}, 28$ Aug. 1996, M. Nee 47108 (LPB, MO, NY, USZ). Prov. Vallegrande, Entre Masicurí y Arenales, 1855'23"S 634' $55^{\prime \prime} \mathrm{W}, 597$ m, 22 Aug. 2012, G. A. Parada et al. 4927 (USZ). Prov. Warnes, Quebrada el Jipa, $17^{\circ} 29^{\prime} \mathrm{S} 63^{\circ} 08^{\prime} \mathrm{W}, 325 \mathrm{~m}, 11$ July 1994, M. Nee 45160 (K, LPB, MO, NY, USZ). CONSERVATION STATUS. Least Concern (LC).
PHENOLOGY. Flowers during the winter dry season, principally from June to September.

NOTES. A conspicuously woody liana with a campanulate corolla and oblong scarious sepals, the inflorescence often subracemose or corymbose in appearance. The ripe fruit is distinctive as the sepals are persistent, become papery and spread outwards so aiding dispersal by the wind. The seeds have hallucinogenic properties (Stearn 1976). Ipomoea corymbosa can be confused with $I$. reticulata which has similar coloured flowers and grows in similar habitats but the sepals of $I$. reticulata are elliptic, less than $8 \mathrm{~mm}$ long and it flowers earlier in the year from April to May.

2. Ipomoea clavata (G. Don) Ooststr. ex J. F. Macbr. (Macbride 1931: 3).

Calonyction clavatum G. Don (1838: 264). Type: Ecuador, Ruiz E Pavon s.n. (holotype Herb. Lambert, not found at BM, isotype MA!).

Ipomoea contrerasii L. O. Williams (1970: 189). Type: Guatemala, Petén, Arroyo Paxcaman, Uaxactun, Contreras 3640 (holotype LL, isotype K!).

Twining perennial to c. $5 \mathrm{~m}$; stems with long, white, stiff, spreading hairs. Leaves petiolate, $6-12 \times 5-10$ $\mathrm{cm}$, ovate, sometimes shallowly 3-lobed or with a single lateral lobe, shortly acuminate and mucronate, cordate with rounded auricles, margin often undulate, glabrous, thin in texture, abaxially paler, main veins prominent; petioles $4-4.5 \mathrm{~cm}$, pilose. Inflorescence of 1 (-3)-flowered, axillary, pedunculate cymes; peduncles $0.4-2.5 \mathrm{~cm}$, bracteoles $2 \mathrm{~mm}$, lanceolate, caducous, pedicels $2-4 \mathrm{~cm}$, darker than peduncle, conspicuously thickened upwards, glabrous; sepals subequal, 23 - $28 \times 10 \mathrm{~mm}$, broadly lanceolate, acuminate, glabrous, margin broad, scarious; corolla $7.5-11 \mathrm{~cm}$, glabrous, broadly funnel-shaped, the tube white, limb blue, deeply lobed. Capsule ovoid, c. $2 \mathrm{~cm}$ long, glabrous; seeds $10-13 \times 5 \mathrm{~mm}$, shortly tomentose but with long yellowish marginal hairs.

DISTRIBUTION \& HABITAT. Scattered in disturbed bushy places in areas of good rainfall at low altitudes up to just over $1000 \mathrm{~m}$ along the Andean chain from northern Bolivia to southern Mexico.

SPeCIMEnS eXAMINed. BOLIVIA. La Paz: Prov. Larecaja Muchanes, $15^{\circ} 10^{\prime} \mathrm{S} 67^{\circ} 36^{\prime} \mathrm{W}, 280 \mathrm{~m}$, I. Hinojosa 1156 (LPB). Prov. Nor Yungas, Alto Beni, carretera de Sapecho a Boopi, 450 m, 26 May 1988, R. Seidel 2455 (ARIZ, K, LPB). Prov. Tamayo, ANMI Madidi, UnapaApolo, 14³2'26"S 68²9'46"W, 1022 m, 4 Sept. 2004 (fr.), L. Cayola al. 918 (LPB); ANMI Madidi, entre Azariamas y Sipia, 14²1'19"S 68³2'17"W, 850 m, 21 May 2006, A. Fuentes $\mathcal{E}^{\circ}$ T. Miranda 10895 (CTES, LPB, MO, OXF, USZ). 

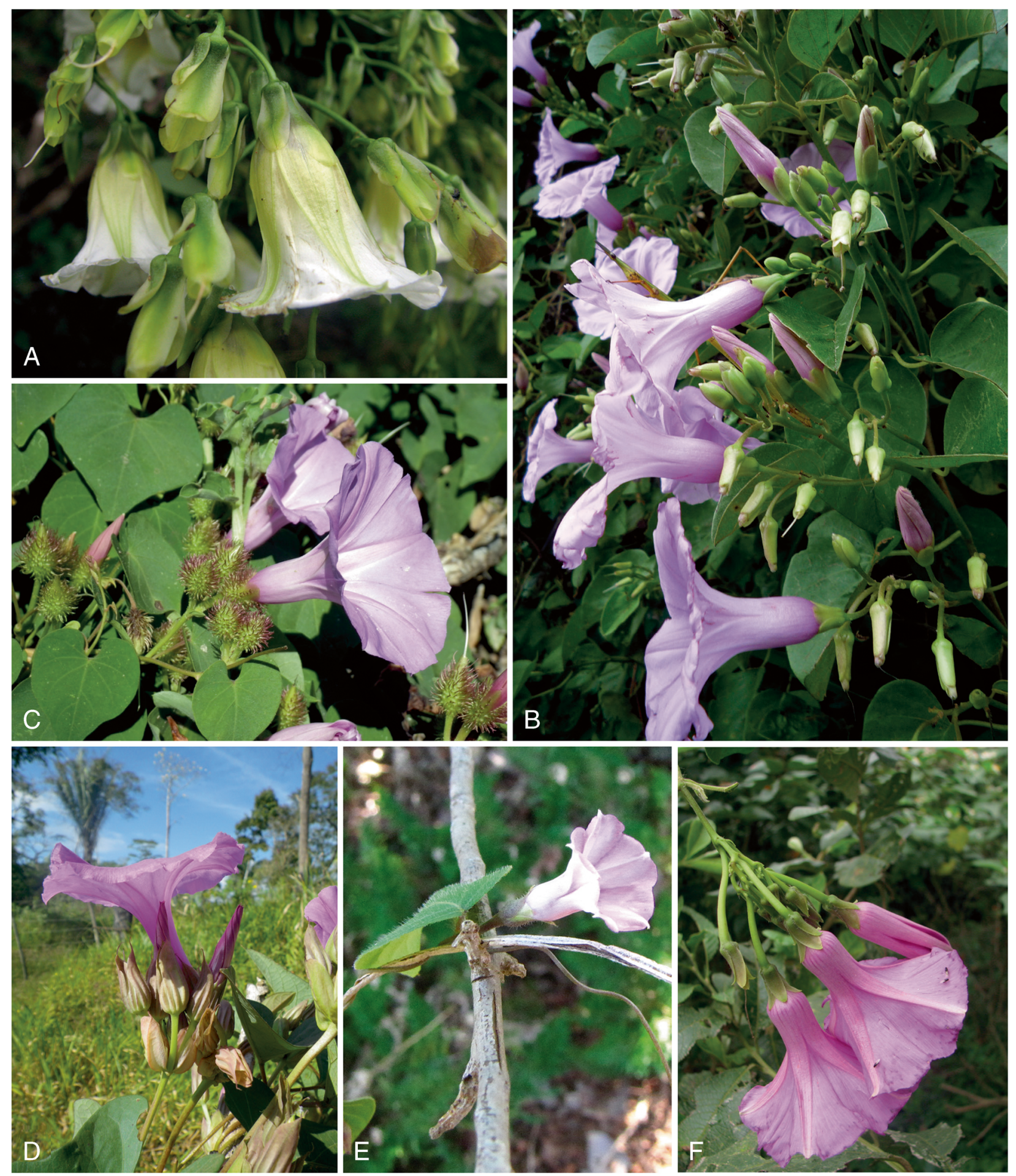

Fig. 1. A Ipomoea corymbosa; B I. abutiloides; C I. crinicalyx; D I. setifera; E I. chiquitensis; F I. regnellii. PHOTOS: A, C, E - F DANIEL SOTO; B BETH WILLIAMS; D JOHN WOOD.

CONSERVATION STATUS. Although very widely distributed in the neotropics, this species is uncommon everywhere. At the present time we have no information about the size or permanence of the populations in Bolivia or elsewhere. Based on its extent of occurrence in Bolivia it should be provisionally classified as Endangered (EN) but further investigation is needed at both national and continental levels.

PHENOLOGY. In Bolivia it is recorded in flower in May. 


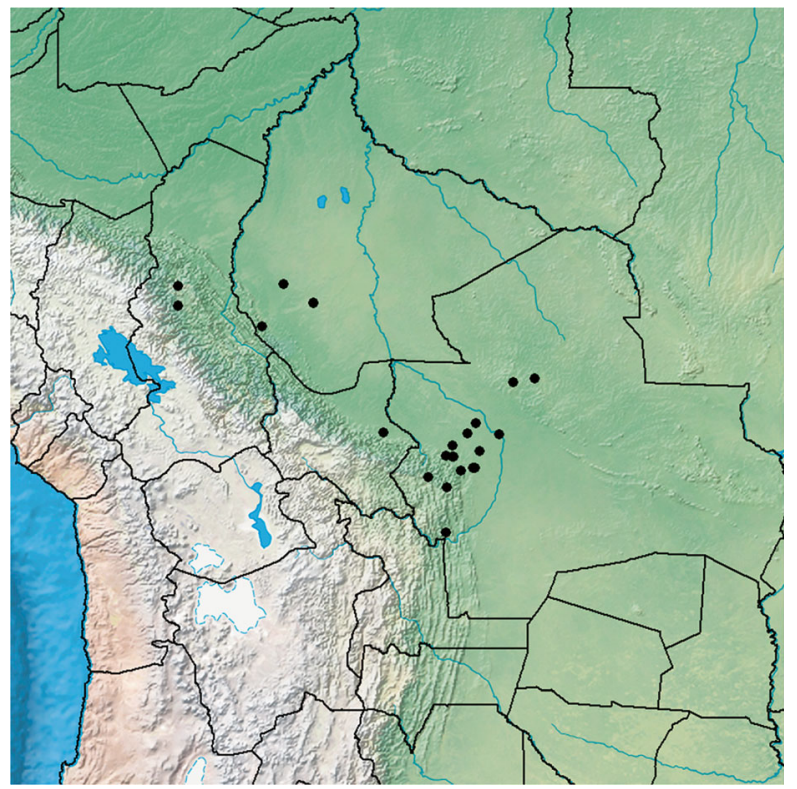

Map 1. Distribution of Ipomoea corymbosa concentration of records in the Santa Cruz area.

showing

NOTES. An unmistakeable species because of its large blue flowers and pilose stems with very long hairs.

3. Ipomoea crinicalyx S. Moore (1895: 402). Type: Brazil, Mato Grosso, S. Moore 953 (holotype BM!).

Twining perennial herb, stems glabrous or puberulent. Leaves petiolate, $3-9 \times 3-9 \mathrm{~cm}$, broadly ovate, cordate with broad sinus, acuminate, glabrous or shortly adpressed pubescent; petioles $1-6 \mathrm{~cm}$. Inflorescence of pedunculate axillary cymes; peduncles $0.5-8 \mathrm{~cm}$; bracteoles very variable sometimes small, linear, caducous, sometimes large, expanded and leaflike; secondary peduncles (if present), $2-6 \mathrm{~mm}$, pedicels $8-21 \mathrm{~mm}$; sepals slightly unequal, oblong-ovate, acute, covered in soft spines, otherwise glabrous, puberulent, or, frequently, farinose, outer $12-14 \times 4-5 \mathrm{~mm}$, inner $14-15 \times 5-6 \mathrm{~mm}$, the scarious margins and upper part spineless; corolla $5.5-8 \mathrm{~cm}$, pink, glabrous outside, limb $4-5 \mathrm{~cm}$, unlobed. Capsule ovoid, glabrous, $14-15 \times 12 \mathrm{~mm}$ with stout rostrate apex $5 \mathrm{~mm}$ long; seeds c. $5 \mathrm{~mm}$, flattened ellipsoid, minutely tomentellous with long, dense, brownish marginal hairs. Fig. 1C.

DISTRIBUTION \& HABITAT. A species with an amphitropical distribution being found in Mexico as well as in South America, where it has a typical Chaco distribution occurring in northern Argentina, southern Brazil, Paraguay and southern Bolivia. In Bolivia it is locally common and characteristic of seasonally wet Chaco forest and scrub extending into the inter-Andean valleys in Tarija, Chuquisaca and

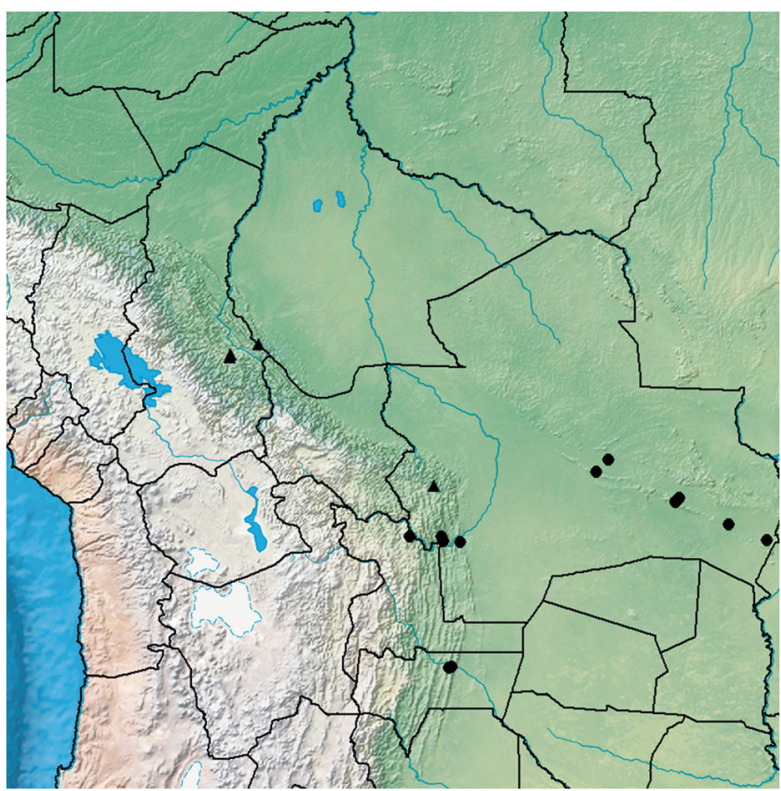

Map 2. Contrasting distributions of Ipomoea echinocalyx (A), a Yungas species, and I. crinicalyx (O), a circum-Chaco species.

Santa Cruz Departments, usually below $600 \mathrm{~m}$ but exceptionally reaching nearly $1400 \mathrm{~m}$ in Belisario Boeto Province. Map 2.

SPECIMENS eXAMINED. BOLIVIA. Chuquisaca: Prov. Boeto, bajando de Nuevo Mundo hacia Santa Rosa, en dirección al Río Grande, $18^{\circ} 55^{\prime} 37^{\prime \prime} \mathrm{S} 64^{\circ} 17^{\prime} 07^{\prime \prime} \mathrm{W}, 1353$ m, 2 March 2006, J. R. I. Wood et al. 22336 (K, LPB). Prov. Zudañez, ANMI El Palmar, Joya Charal, hacia el sector Almendras, 20 Feb. 2015, J. Gutiérrez et al. 2645 (HSB). Santa Cruz: Prov. Chiquitos, c. 25 km W of San José de Chiquitos on road to Pailón, 400 m, 12 April 1998, J. R. I. Wood Eீ F. Mamani 13495 (K, LPB, USZ); Valle de Tucavaca entre Santiago y Santo Corazón, km 20 al norte de Santiago, $18^{\circ} 14^{\prime} 37^{\prime \prime S} 59^{\circ} 29^{\prime} 10^{\prime \prime} \mathrm{W}, 225 \mathrm{~m}, 25$ April 2008, J. R. I. Wood et al. 24462 (K, LPB, UB, USZ); 20 km al oeste de San José de Chiquitos, $17^{\circ} 46^{\prime} 38^{\prime \prime} \mathrm{S}$ 6057'25"W, $261 \mathrm{~m}, 7$ April 2009, J. R. I.Wood Eं P. Pozo 26077 (K, LPB, UB, USZ); 5 km de San José de Chiquitos en el camino nuevo a Taperas, 17³4'S 6044'36"W, 267 m, 3 May 2012, J. R. I. Wood E' D. Soto 27566 (K, LPB, USZ); Santiago de Chiquitos on descent of escarpment into Tucavaca, 18 $18^{\prime} 34^{\prime \prime S} 59^{\circ} 33^{\prime} 01^{\prime \prime} \mathrm{W}, 309$ m, 20 April 2013, J. R. I. Wood E B. Williams 27900 (K, LPB, USZ). Prov. Cordillera, PN Kaa-Iya del Gran Chaco, $15 \mathrm{~km}$ E of San José, 300 m, 20 April 2001, A. Fuentes 2992 (USZ); c. $15 \mathrm{~km}$ al sur de Abapó en el camino a Camiri, $19^{\circ} 02^{\prime} \mathrm{S}$ $63^{\circ} 24^{\prime} \mathrm{W}, 600 \mathrm{~m}, 27$ April 2012, J. R. I. Wood Ẽ F. Mamani 27491 (K, LPB, OXF, USZ). Prov. Germán Busch, 51 km del Carmen Rivero Tórrez en camino a Rincón del Tigre, 18 25'11"S 58 21'24"W, 112 m, 30 March 2009, J. R. I. Wood Eं P. Pozo 25924 (K, LPB, UB, USZ); between Yacuses and Puerto Suárez, 1859'16"S 5755'39"W, 122 m, 19 April 2013, J. R. I. Wood et al. 27884 (K, LPB, OXF). Prov. Vallegrande, $4-7 \mathrm{~km}$ de Arenales, $18^{\circ} 52^{\prime}-59^{\prime} \mathrm{S}$ 
$63^{\circ} 43^{\prime}-44^{\prime} \mathrm{W}, 560-703$ m, 19 May 2010, G. A. Parada E V. Rojas 2512 (MO, OXF, USZ); ibid., camino Algodonal a Masicurí, 1900'36"S 6341'49"W, 542 m, 6 April 2011 , G. A. Parada et al. 3154 (LPB, USZ). Tarija, Prov. Gran Chaco, $15 \mathrm{~km}$ de Villamontes a Palos Blancos, $21^{\circ} 15^{\prime} 37^{\prime} \mathrm{S}, 63^{\circ} 32^{\prime} 46^{\prime \prime W}, 570 \mathrm{~m}, 26$ Nov. 2007 , M. Mendoza et al. 2674 (LPB, USZ); $10-20 \mathrm{~km}$ de Villamontes en dirección a Palos Blancos. $21^{\circ} 16^{\prime} 44^{\prime \prime} \mathrm{S}$ 6335'34"W, 605 m, 24 March 2013, J. R. I. Wood et al. 27606 (LPB, OXF, USZ).

CONSERVATION STATUS. Least Concern (LC).

PHENOLOGY. Flowers principally from March to May at the end of the rainy season.

NOTES. The presence of soft spines on the sepals makes this species unmistakeable and only likely to be confused with Ipomoea setosa and I. echinocalyx. From the former it is distinguished by the absence of soft spines everywhere except on the calyx and from I. echinocalyx by the longer peduncles, shorter sepals, less hairy leaves and pink corolla.

4. Ipomoea echinocalyx Meisn. (Meisner 1869: 223). Type: Brazil. Minas Gerais, Lagoa Anta, Warming (holotype BR!).

Twining perennial herb reaching $4 \mathrm{~m}$; stems thinly to densely pubescent. Leaves petiolate, $7-20 \times 6-15$ $\mathrm{cm}$, ovate, cordate with rounded auricles, shortly acuminate, both surfaces pubescent but abaxially more densely so and paler; petioles $5-18 \mathrm{~cm}$, pubescent. Inflorescence of 1 - 3-flowered, axillary cymes; peduncles $0-4 \mathrm{~mm}$; bracteoles deltoid, up to $8 \mathrm{~mm}$ long; pedicels $15-40 \mathrm{~mm}$, unequal in length, thinly pilose; sepals unequal, outer $15-25 \times 3$ - $4 \mathrm{~mm}$, lanceolate or narrowly ovate, acuminate, covered in soft spines, which diminish towards the apex, thinly pilose with white hairs, inner sepals 12 $16 \mathrm{~mm}$, lanceolate, terminating in a long mucro, thinly pilose but nearly spineless, margins scarious; corolla c. $7 \mathrm{~cm}$, funnel-shaped, cream or white, glabrous outside, limb slightly lobed, c. $5 \mathrm{~cm}$ diam. Capsule and seeds unknown.

DISTRIBUTION \& HABITAT. Known from Central Brazil and Bolivia and apparently always infrequent in both countries. In Bolivia it is an uncommon plant of scrub derived from moist Yungas forest in the Yungas of La Paz and the Amboró Park and grows between 500 and $1500 \mathrm{~m}$. Map 2.

SPeCimens eXamined. BoliviA. La Paz: Prov. Caranavi, Alto Corocoro, $9 \mathrm{~km}$ NE of Caranavi, $1400 \mathrm{~m}, 16$ Jan. 1984. E. Garcia 482 (LPB); W side of Serranía de Bellavista between Caranavi and Alto Beni, 1500 m, 4 May 2002, J. R. I. Wood E T. F. Daniel 18388 (HSB, K, LPB); $25 \mathrm{~km}$ de Caranavi pasando Unidad Educativa Colorados de Bolivia, 1544'08"S 67³0'13"W, 850 m, 8
May 2008, M. Mendoza 3108 (K, USZ). Prov. Sud Yungas, Corendo, 15 $30^{\prime} \mathrm{S} 66^{\circ} 59^{\prime} \mathrm{W}, 550 \mathrm{~m}, 25$ May 1994, G. Quintana et al. 1124 (LPB). Santa Gruz: Prov. Florida, PN Amboró, Río San Rafael, 10 km NE of Mairana, pasando La Yunga, $18^{\circ} 02^{\prime} 03^{\prime \prime S}$, 635'ㅇ' 03 "W, 1500 m, 3 - 10 March 1993, I. G. Vargas et al. 2132 (MO, NY, OXF).

CONSERVATION STATUS. Known from only five locations in Bolivia, four in La Paz Department and one in Santa Cruz, and unlikely to be present in much of the intervening country of the Chapare, the Bolivian populations of this species should be provisionally treated as Vulnerable (VUL) based on its area of occurrence at about $12,400 \mathrm{~km}^{2}$ until the exact state of its populations is better known. Certainly the kind of Yungas scrub it favours is vulnerable to clearance for cultivation although the Santa Cruz location lies within the boundaries of the Amboró National Park.

PHENOLOGY. Flowers towards the end of the rainy season from March to May.

NOTES. Obviously related to Ipomoea crinicalyx but distinguished by the near absence of peduncles, much longer outer sepals and white or cream flowers. Additionally I. echinocalyx is a much more hirsute plant with fewer flowers in each cyme.

5. Ipomoea regnellii Meisn. (Meisner 1869: 266). Type: Brazil, Minas Gerais, Caldas, A. F. Regnell (lectotype BR!, designated by O’Donell 1952: 236).

Twining perennial herb, stems thinly pubescent to densely pilose. Leaves petiolate, $4-15 \times 3-12 \mathrm{~cm}$, ovate, cordate with rounded auricles, shortly acuminate to an obtuse and mucronate apex, adaxially thinly puberulent to subtomentose, abaxially weakly to densely tomentose; petioles $1.5-11 \mathrm{~cm}$, thinly pubescent to tomentose. Inflorescence of shortly pedunculate axillary, many-flowered umbellate cymes, peduncles $1-5.5 \mathrm{~cm}$; bracteoles $1.5-2 \mathrm{~mm}$, lanceolate, caducous; secondary peduncles $6-8 \mathrm{~mm}$; pedicels $8-$ $30 \mathrm{~mm}$, relatively long; sepals unequal, lanceolate, obtuse and broadly mucronate, pale green, thinly to densely pubescent, outer $7-11 \times 1-3 \mathrm{~mm}$, margins often ciliate, the inner $9-12 \times 3-4 \mathrm{~mm}$, often with scarious margins; corolla $5-8 \mathrm{~cm}$, funnel-shaped, pink, densely short-pubescent, limb c. $4 \mathrm{~cm}$ diam. Capsule ellipsoid, $11-12 \times 7-8 \mathrm{~mm}$, rostrate, glabrous; seeds $6 \mathrm{~mm}$, pubescent (immature). Fig. 1F.

DISTRIBUTION \& HABITAT. Widely distributed in moist forest regions of tropical South America. In Bolivia very widely distributed at the edges of forest and in scrub derived from moist forest from the Santa Cruz area north to Pando but apparently absent from the wettest forest of the Chapare and much of Pando. It is 


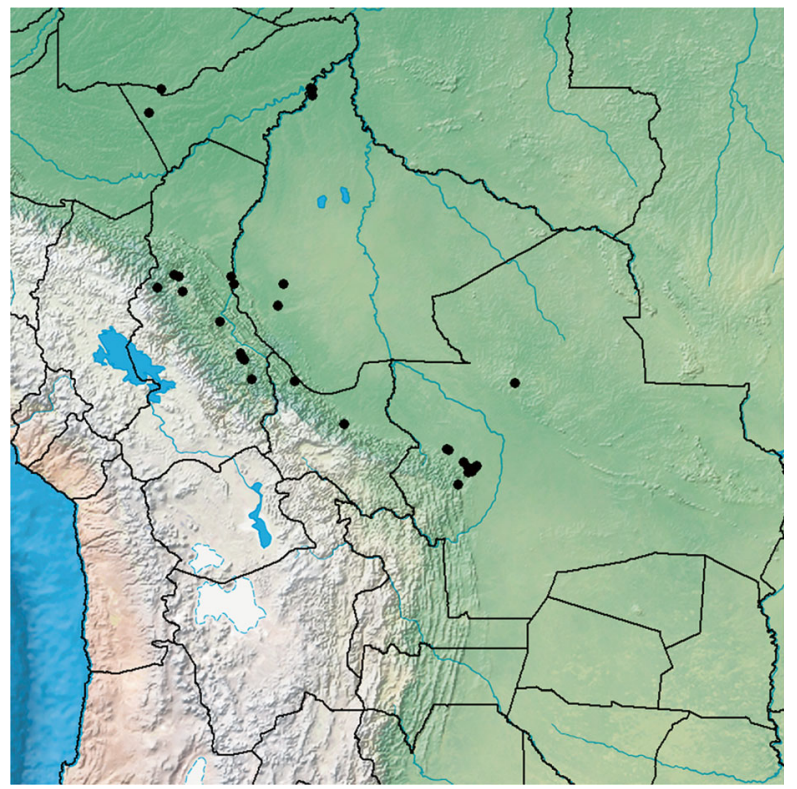

Map 3. Distribution of Ipomoea regnellii a lowland moist forest species, probably undercollected in the north of Bolivia.

possibly under-recorded because of its winter flowering pattern but is certainly locally common in some areas, notably in the foothills to the west of Santa Cruz. Map 3.

SELECTED SPECIMENS OF 32 EXAMINED. BOLIVIA. Beni: Prov. Ballivian, Rurrenabague, $14^{\circ} 30^{\prime} \mathrm{S} 67^{\circ} 30^{\prime} \mathrm{W}, 230$ m, 8 Sept. 1989, D. Williams 955 (K, LIL, LPB, MO, NY, USZ). Prov. Vaca Diaz, Riberalta, $11^{\circ} 00^{\prime} \mathrm{S} 66^{\circ} 08^{\prime} \mathrm{W}, 160$ m, 29 June 1992, A. Gentry et al. 77549 (MO). Cochabamba: Prov. Chapare, PN Isiboro-Sécure (TIPNIS), Cordillera de Mosetenes, Laguna Carachupa, 16 ${ }^{\circ} 14^{\prime} \mathrm{S} 66^{\circ} 25^{\prime} \mathrm{W}, 1300$ m, M. Kessler et al. 13263 (LPB). La Paz: Prov. Caranavi, Carrasco, camino de Caranavi a Alto Beni, $15^{\circ} 43^{\prime} 23^{\prime \prime S} 67^{\circ} 23^{\prime} 21^{\prime \prime W}, 1110$ m, 23 Sept. 2007, M. Mendoza et al. 2631, (LPB, USZ). Prov. Nor Yungas, $25 \mathrm{~km}$ NW de Abaroa, $1120 \mathrm{~m}, 8$ Aug. 1982, F. de la Puente 1647 (CIP, Lima). Prov. Sud Yungas, San Bartolome, Río Bopi, 750 - 900 m, 1 - 22 July 1939, B. Krukoff 10078 (F, GH, K, MICH, MO, NY, US). Prov. Tamayo, PN Madidi, Azariamas-Resina, 14²19'39"S 68 33'57"W, 660 m, 30 May 2005, A. AraujoM. et al. 1851 (ARIZ, MO). Pando: Prov. Madre de Dios, $2 \mathrm{~km}$ de la Com. Las Piedras, $11^{\circ} 01^{\prime} 20^{\prime \prime S} 66^{\circ} 06^{\prime} 42^{\prime \prime} \mathrm{W}, 25$ Aug. 2008, D. Rocabado Ẽ E. Calzadilla 949 (USZ). Prov. Suárez, Río Tahuamanu, proximo a las juntas con el Río Mayumanu, 11 26'08"S 6901'02"W, 7 Sept. 2000, I. Vargas et al. 5149 (F). Santa Cruz: Prov. Ibañez, Pampa de Urubó entre Santa Cruz y Porongo, 1751'22"S 6319'26"W, 479 m, 25 May 2008, J. R. I. Wood et al. 24918 (K, LPB, UB, USZ). Prov. Ichilo, Buenavista, $17^{\circ} 27^{\prime} 48^{\prime \prime S} 63^{\circ} 40^{\prime} 13^{\prime \prime W}, 373$ m, 27 July 2014, J. R. I. Wood Ẽ D. Soto 27953 (K, LPB, OXF, USZ).

CONSERVATION STATUS. Least concern (LC). Widely distributed in areas of moist forest throughout tropical
South America, this species is well adapted to survival as long as not all forest and scrub is clear-felled as in the Mennonite settlements of Eastern Bolivia. It survives well in secondary scrub and around fences in areas derived from forest and may be favoured by moderate levels of intervention.

PHENOLOGY. Flowers during the winter dry season from late May to September.

NOTES. Usually readily identified by the pubescent leaves and corolla, combined with the narrow, lanceolate, obtuse sepals.

6. Ipomoea chiquitensis J. R. I. Wood E $R$. W. Scotland, sp. nov. Type: Bolivia, Santa Cruz, Velasco, 6-10 km $\mathrm{N}$ de San Rafael en el camino a San Miguel, J. R. I. Wood Eं D. Soto 27388 (holotype USZ; isotypes K, LPB).

http:/ /www.ipni.org/urn:lsid:ipni.org:names:77148113-1

Very slender, possibly annual, twining herb reaching no more than $1 \mathrm{~m}$ in height, stems glabrous. Leaves petiolate, $2.5-5.5 \times 1.5-4.5 \mathrm{~cm}$, ovate, cordate with rounded auricles, becoming truncate upwards, apex acute and minutely mucronate, margin entire, adaxially thinly pilose, abaxially glabrous; petioles, $0.5-3 \mathrm{~cm}$ long, diminishing in length upwards, pubescent. Inflorescence of very shortly pedunculate 1 - 2-flowered cymes from the leaf axils; peduncles $3-7 \mathrm{~mm}$, elongating in fruit to $20 \mathrm{~mm}$, glabrous; bracteoles filiform, $1 \mathrm{~mm}$; pedicels $3-7 \mathrm{~mm}$, pubescent; sepals subequal, $5-6 \times 2.5 \mathrm{~mm}$ (accrescent to $6.5 \mathrm{~mm}$ ), ovate, acute terminating in an aristate point, pilose with scattered long multicellular hairs, margins slightly paler, inner sepals slightly shorter and paler, nearly glabrous; corolla $2.2 \mathrm{~cm}$ long, uniformly pink, glabrous, funnel-shaped, midpetaline bands ending in a small white tooth; stamens included, filaments slightly unequal, glabrous apart from expanded pubescent basal part, shorter filaments $5-6 \mathrm{~mm}$, longer $7-8$ $\mathrm{mm}$, anthers linear, $1.25 \times 0.25 \mathrm{~mm}$; style $11 \mathrm{~mm}$, glabrous, stigma obscurely 2-lobed. Capsule $6 \times 3$ $\mathrm{mm}$, ovoid, glabrous, rostrate, the style base persistent as a pyramidal point $1.5 \mathrm{~mm}$ long. Figs 1E, 2.

RECOGNITION. Molecular studies suggest Ipomoea chiquitensis is most closely related to I. regnellii, with which it appears to have nothing in common. It is a distinctive species readily recognised by the very small, shortly pedunculate flowers, adaxially pilose leaves and small pointed pilose sepals. The small glabrous corolla (c. $2.2 \mathrm{~cm}$ long) is only matched by $I$. dumetorum and some species in the Batatas group such as I. ramosissima but is readily distinguished from all of these by the distinctive ovate, acute sepals. 

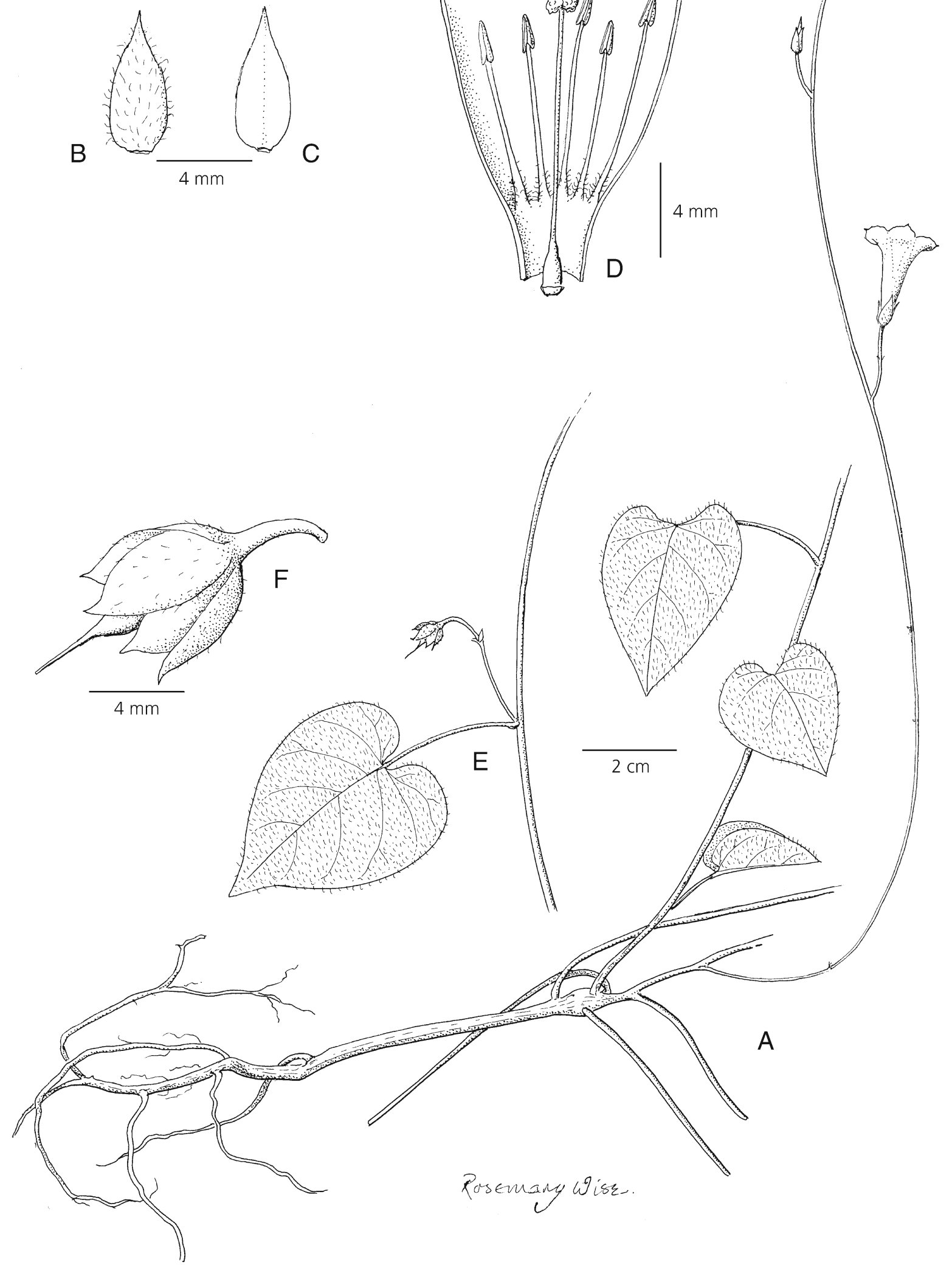

Fig. 2. Ipomoea chiquitensis. A habit; B outer sepal; C inner sepal; D corolla opened up to show stamens, ovary and style; E shoot with young fruiting inflorescence; $F$ calyx with young fruit. From Wood \& Soto 27388. DRAWN BY ROSEMARY WISE. 
DISTRIBUTION \& HABITAT. A Bolivian endemic known from a single location north of San Rafael along the road to San Miguel de Velasco. It grows on a granite platform around small islands of vegetation surrounding plants of Commiphora leptophoeos (Mart.) J. B. Gillett, these being seasonally moist, and protected from grazing by spiny bromeliads. Map 10 .

SPECIMEnS eXAMINed. BoliviA. Santa Cruz: Prov. Velasco, 6 - $10 \mathrm{~km} \mathrm{~N}$ de San Rafael en el camino a San Miguel, 16 $43^{\prime} 55^{\prime \prime S} 60^{\circ} 44^{\prime} 29^{\prime \prime} \mathrm{W}, 420$ m, 4 April 2011, J. R. I. Wood E D. Soto 27388 (holotype USZ; isotypes $\mathrm{K}, \mathrm{LPB}$ ).

CONSERVATION STATUS. Although only collected once this population has been observed carefully over two years. It is almost certainly the rarest of Bolivan species of Ipomoea, being known from a single rock platform where it is not particularly abundant. Although not of obvious economic value, the rock platform could be destroyed by road-widening or by use as a quarry or rubbish dump. For these reasons Ipomoea chiquitensis should be categorised as Critically Endangered (CR).

PHENOLOGY. Found in flower in April.

7. Ipomoea rubens Choisy (1834: 463). Type: India, Wallich 1421 (lectotype G 00227258, designated here, isolectotypes $\mathrm{G}, \mathrm{K}-\mathrm{W})$.

Ipomoea riparia G. Don (1838: 265). Type: São Tome,

Guinea, (probable holotype BM).

Ipomoea villicalyx N. E. Br. (Brown 1894: 64). Type:

Paraguay, Gibert (holotype K)

Twining perennial herb, stems tomentose, to several metres high. Leaves petiolate, $4-8 \times 3-5 \mathrm{~cm}$, ovatedeltoid, often shallowly 3-lobed, cordate with rounded auricles, apex acute, adaxially pubescent, abaxially grey-tomentose; petioles $2-4 \mathrm{~cm}$, grey-tomentose. Inflorescence of compact, axillary, pedunculate cymes; peduncles $3-12 \mathrm{~cm}$, densely woolly-pilose; bracteoles $3-7 \mathrm{~mm}$, linear, caducous; secondary peduncles (if present) $2-3 \mathrm{~mm}$; pedicels $5-17 \mathrm{~mm}$, pilose; sepals somewhat unequal, outer (8-) $10-14 \mathrm{~mm}$, accrescent to $16 \mathrm{~mm}$ in fruit, ovate-deltoid, acute (or obtuse), pilose, inner sepals $8-12 \mathrm{~mm}$, obtuse, pilose, margins scarious; corolla $4-5.5 \mathrm{~cm}$, funnel-shaped, pink, sericeous-pubescent, limb $4-5 \mathrm{~cm}$ diam. Capsule globose, $8-13 \times 11-12 \mathrm{~mm}$, enclosed by sepals, glabrous; seeds $5-6 \mathrm{~mm}$ long, pilose.

TYPIFICATION. In designating a lectotype we have chosen the best of three sheets at Geneva, where Choisy worked.

DISTRIBUTION \& HABITAT. A pantropical species originally described from India but with every appearance of being native in Bolivia although molecular studies suggest an Old World origin. In Bolivia widespread but scattered in the eastern lowlands below about $350 \mathrm{~m}$ but restricted to the Amazon watershed apart from records from the Pantanal. It is a plant with a very distinct ecology, growing beside slow-moving tropical rivers, streams and small lakes. Map 4.

SELECTED SPECIMENS OF 22 EXAMINED. BOLIVIA. Beni: Prov. Cercado, Laguna Suárez, 1452'S 6452'W, 160 m, 19 June 1996, N. Ritter E M. Ritter 3346 (BOLV, MO). Prov. Marban, PN Isibore-Sécure (TIPNIS), $16^{\circ} 00$ 'S $65^{\circ} 15^{\prime} \mathrm{W}, 200 \mathrm{~m}, 1$ June 1992, R. Seidel 6606 (LPB). Prov. Vaca Diaz, Riberalta, $11^{\circ} 00^{\prime} \mathrm{S} 66^{\circ} 04^{\prime} \mathrm{W}$, 150 m, 23 May 1987, J. Solomon 16736 (LPB, MO). Cochabamba: Prov. Carrasco, Puerto Villarroel, 1651'S 6448'W, 194 m, R. Chávez de Michel 3269 (LPB). Pando: Manuripi, Conquista, 27 March 1956, E. de la Sota 987 (LIL). Prov. Federico Roman, Río Negro, Camp. Mocú, 952'S 6542'W, 150 m, 15 July 1992, Vargas et al. 980 (LPB). Santa Cruz: Prov. Germán Busch, Laguna Cáceres, Puerto Suárez, $18^{\circ} 58^{\prime S} 57^{\circ} 47^{\prime} 30^{\prime \prime} \mathrm{W}, 80 \mathrm{~m}, 5$ May 1990, R. Frey et al. 494 (MO, USZ). Prov. Chiquitos, $4 \mathrm{~km} \mathrm{~S}$ of Robore, Colonia de Ayoreos, 20 April 1980, A. Krapovickas Ẽ A. Schinini 36509 (CTES, LIL). Prov. Nuflo de Chávez

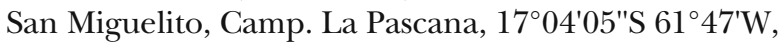
260 m, 28 March 1995, A. Fuentes 541 (LPB, USZ). Prov. Sara, $16 \mathrm{~km}$ NW of Santa Rosa del Sara, Laguna Juan Chulo, $17^{\circ} 00^{\prime} \mathrm{S} 63^{\circ} 44^{\prime} \mathrm{W}, 250 \mathrm{~m}, 9-10$ March 1996, A. Fuentes 1586 (LPB, NY, USZ). Prov. Velasco, El Refugio, en camino a El Toledo, 1446'18"S 61 02'19"W, 176 m, 21 April 2004, J. R. I. Wood E H. Huaylla 20754 (HSB, K, LPB, USZ). Prov. Warnes, Quebrada El Jipa, $17^{\circ} 29^{\prime} \mathrm{S} 63^{\circ} 08^{\prime} \mathrm{W}, 325 \mathrm{~m}, 11$ July 1994, M. Nee 45145 (LPB).

CONSERVATION STATUS. Least concern (LC).



Map 4. Distribution of Ipomoea rubens (-), a species of tropical rivers and lakes. 
PHENOLOGY. It has been found in flower in nearly every month of the year.

NOTES. The pilose sepals and grey-tomentose leaves can lead to confusion with Ipomoea longibarbis but the corolla is shorter and the bracteoles much smaller. Moreover their habitats are quite different, I. rubens growing by water whereas I. longibarbis is a plant of very dry scrub.

8. Ipomoea sericosepala J. R. I. Wood $\mathcal{E} R$. W. Scotland, nom. nov.

http:/ /www.ipni.org/urn:lsid:ipni.org:names:77148114-1

Basionym: Rivea cordata Choisy, Prodromus Systematis Naturalis 9: 326 (1845). Type: Brazil, Minas Gerais, San Francisco prope Salgado, Martius s.n. (lectotype M, designated by Austin \& Staples 1991: 272), non Ipomoea cordata L. B. Sm. \& B. G. Schub. (Smith \& Schubert 1939).

Turbina cordata (Choisy) Austin \& Staples (1983: 64). Ipomoea martii Meisn. (Meisner 1869: 258), nom. illeg. Type: as for Rivea cordata.

Liana climbing high over shrubs to $7 \mathrm{~m}$, stems whitetomentose, especially when young, latex white. Leaves petiolate, $4-8 \times 8-9 \mathrm{~cm}$, broadly ovate, apex acute and mucronate or (less commonly) obtuse or retuse, base truncate to shallowly cordate, adaxially glabrous, glabrescent or shortly pubescent, abaxially grey-sericeous with long silky hairs; petioles $1-6 \mathrm{~cm}$, tomentose. Inflorescence of pedunculate axillary cymes, these often leafy and appearing to be side branches; peduncles 3-13 $\mathrm{cm}$; bracts resembling small leaves; bracteoles c. $5 \mathrm{~mm}$, linear-lanceolate, abaxially sericeous, caducous; secondary peduncles up to $9 \mathrm{~cm}$ long; pedicels $6-32 \mathrm{~mm}$; sepals unequal, outer $8-10 \times 3-4 \mathrm{~mm}$, oblong, obtuse and sometimes mucronate, sericeous, inner $11-14 \times 6 \mathrm{~mm}$, elliptic-obovate, rounded, mucronate, sericeous, the margins broad, scarious, glabrous; corolla $5-7 \mathrm{~cm}$, funnel-shaped, pink, sericeous with long silky hairs, limb c. $5 \mathrm{~cm}$ diam., shallowly lobed. Capsule ovoid, 14-18 $\times 7$ $10 \mathrm{~mm}$, glabrous; seeds $1-2$, narrowly ellipsoid, $8-10$ $\mathrm{mm}$, tomentellous.

DISTRIBUTION \& HABITAT. Restricted to scattered locations in Brazil and Bolivia - records from Peru (Austin \& Staples 1991: 273) are errors for the very similar Ipomoea pearceana Kuntze. In Brazil it is far more common than I. abutiloides but in Bolivia, with the single exception of a population on a rock platform near San José Campamento in Velasco, this species is characteristic of the western Chaco and Serrano Chaqueño scrub and dry forest along the Río Grande Valley entering the Andes (Map 5).

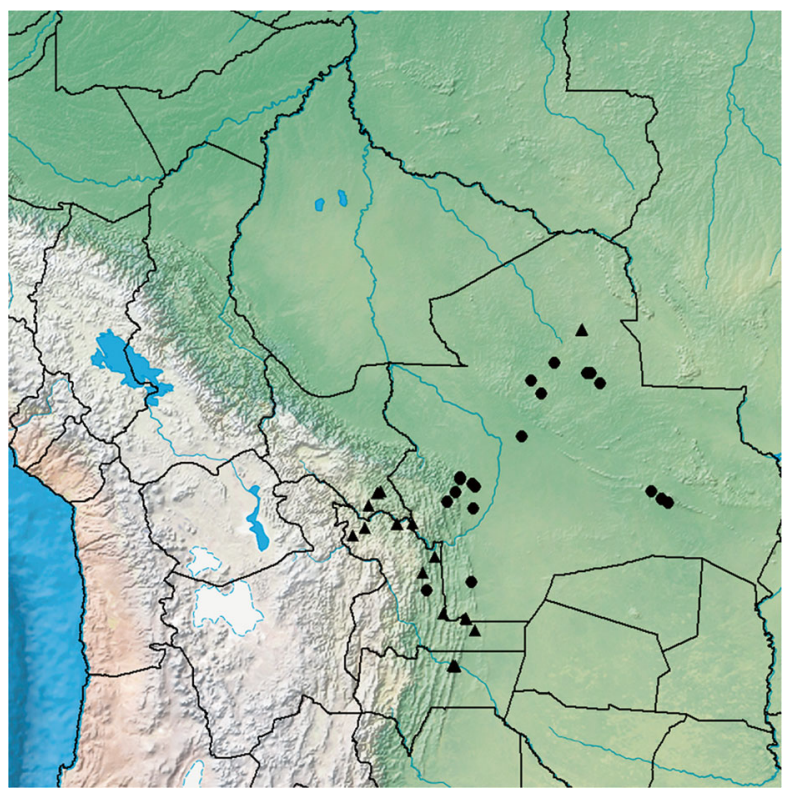

Map 5. Contrasting distributions of Ipomoea sericosepala ( $\mathbf{A})$, principally in the drier Andean foothills and valleys and I. abutiloides (-), a species of seasonally dry lowland forest.

SELECTED SPECIMENS OF 23 EXAMINED. BOLIVIA. Chuquisaca: Prov. Luis Calvo, Calvo, Muyupampa, Canton Ticucha, 19¹8'19"S 6352'46"W, 836 m, 4 June 2009, J. A. Peñaranda E J. G. Tudela, 1116 (MO, OXF). Prov. Oropeza, Com. Noctulo, 1847'03"S 6507'06"W, 1859 m, 17 Jan. 2004, J. Gutiérrez 406 (HSB, K). Prov. Tomina, between Puente Azero and Thiumayo, 19 35'22"S 6405'19"W, 1105 m, 19 Dec. 2006, J. A. Peñaranda et al. 312 (MO). Prov. Zudañez, bajando a la comunidad de Jacha Pampa del cerro, al este de Mojocoya, 18 43'48"S 64'33'03"W, 1605 m, 30 Jan. 2005, J. R. I. Wood E $H$. Huaylla 21549 (K, LPB). Cochabamba: Prov. Campero, Valle de Tunas Pampa, entre Aiquile y Lagar Pampa, $18^{\circ} 23^{\prime} 12^{\prime \prime S} 65^{\circ} 03^{\prime} 21^{\prime \prime W}, 1770$ m, 26 Jan. 2005, J. R. I. Wood E M. Mendoza 21517 (K, LPB). Santa Cruz: Prov. Cordillera, $5 \mathrm{~km}$ al norte de Boyuibe en el camino a Camiri, 20²4'66"S 6319'09"W, 910 m, 25 Nov. 2003, J. R. I. Wood et al. 20107 (HSB, K, LPB, USZ). Prov. Vallegrande, camino Pucará - Santa Rosa, bajando hacia el Río Grande, 1842'11"S 64¹7'05"W, $1361 \mathrm{~m}$, 18 Feb. 2007, J. R. I. Wood et al. 22793 (K, LPB). Prov. Velasco, $24 \mathrm{~km}$ W of San José de Campamento hacia Las Juntas, 15¹4'46"S 6114'34'W, 300 m, 1 May 1996, R. Guillén et al. 4272 (ARIZ, NY, USZ). Tarija: Prov. Gran Chaco, $5-5.7 \mathrm{~km} \mathrm{~W}$ of Villamontes on road to Tarija, 21 $15^{\prime} 28^{\prime \prime} \mathrm{S}, 63^{\circ} 30^{\prime} 40^{\prime \prime} \mathrm{W}, 400$ m, 9 Feb. 2006, M. Nee Ẽ I. Linneo 54033 (MO, NY, USZ).

CONSERVATION STATUS. Least Concern (LC).

PHENOLOGY. Flowers mainly during the rainy season from December to early May.

ETYMOLOGY. The name Ipomoea martii is illegitimate being based on the same type as Rivea cordata. Meisner chose to provide a new name when a combination 
should have been used, the name I. cordata then being available. As it is no longer available because of the existence of I. cordata L. B. Sm. \& B. G. Schub., we have provided the name $I$. sericosepala for this species, the epithet sericosepala referring to the distinctive sericeous sepals which is apparently the only character distinguishing it from $I$. abutiloides.

NOTES. Ipomoea sericosepala and I. abutiloides are similar in their liana habit, leaves grey tomentose or sericeous beneath, their oblong-elliptic sepals and their inflorescences which have a tendency to become leafy and racemose or even paniculate towards the branch tips. They are best distinguished by the sepal indumentum, I. sericosepala having sericeous sepals while those of I. abutiloides are glabrous. The two species intergrade in the Abapo area of Bolivia where their ranges overlap (Mendoza 2725, 2736).

9. Ipomoea abutiloides (Kunth) G. Don (1838: 273). Convolvulus abutiloides Kunth (1819: 106). Type: Ecuador, Guayaquil, Bonpland s.n. (holotype P00670760!).

Turbina abutiloides (Kunth) O’Donell (1950c: 505)

Liana climbing high over shrubs to $7 \mathrm{~m}$, stems whitetomentose, especially when young, roots tuberous. Leaves petiolate, $3-10 \times 3-11 \mathrm{~cm}$, broadly ovate, base truncate to subcordate, apex retuse, rounded or obtuse, adaxially pubescent, abaxially grey-tomentose; petioles (1-) $3-6(-10) \mathrm{cm}$, pubescent to tomentose. Inflorescence of axillary and terminal cymes, the later compound and often paniculate or racemose in form, sometimes distinctly leafy; peduncles $2-11 \mathrm{~cm}$, tomentose; bracteoles $2-9 \mathrm{~mm}$, linear, tomentose, soon caducuous; short (c. $5 \mathrm{~mm}$ ), secondary and tertiary peduncles often present; pedicels $5-25 \mathrm{~mm}$, tomentose; calyx narrow and \pm cylindrical, sepals subequal, $10-14 \times 4-7 \mathrm{~mm}$, oblong-obovate, obtuse to rounded, drying brown, glabrous or nearly so, inner c. $2 \mathrm{~mm}$ longer than outer, the margins broad and scarious; corolla $5-7 \mathrm{~cm}$, funnel-shaped, pink, pubescent in bud, glabrescent, limb $4-5 \mathrm{~cm}$, weakly lobed. Capsule glabrous, ovoid, $14-17 \times 6-7 \mathrm{~mm}$; seeds reported as usually solitary, $9-10 \mathrm{~mm}$ long, minutely tomentellous. Fig. $1 \mathrm{~B}$.

DISTRIBUTION \& HABITAT. In Bolivia locally abundant in Chiquitano Dry Forest and in well-developed moister chaco Forest; abundant in the Santa Cruz area and most of the Chiquitania but strangely absent elsewhere. The Bolivian population is disjunct from other, apparently mostly disjunct populations in coastal Ecuador, northern Venezuela, Bahia in Brazil, Colombia and Panama. Map 5.

SELECTED SPECIMENS OF 22 EXAMINED. BOLIVIA. Chuquisaca: Prov. Siles, between Puente Azero and Monteagudo,
1100 m, 13 March 1996, M. Serrano 1506 (HSB). Santa Cruz: Prov. Chiquitos, c. $2 \mathrm{~km}$ al $\mathrm{W}$ de Limoncito en el camino a Chochís, 18²16'35"S 5949'51"W, 484 m, 24 March 2011, J. R. I. Wood Eं M. Mendoza 27315 (K, LPB, USZ). Prov. Cordillera $1.3 \mathrm{~km}$ E of La Mora on Santa Cruz-Abapó highway, $18^{\circ} 27^{\prime} \mathrm{S} \quad 63^{\circ} 12^{\prime} \mathrm{W}, 500 \mathrm{~m}, 14$ March 1998, M. Nee 48677 (K, MO, NY, USZ); Prov. Florida, Com. Bellavista, 18¹9'55"S 6440'35"W, 1000 1100 m, 4 Aug. 2006 (fr.), D. Villarroel et al. 501 (MO, NY). Prov. Ibañez $2.5 \mathrm{~km}$ E along Brecha 5 leaving Santa Cruz-

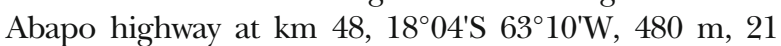
March 1998, M. Nee 48723 (NY, USZ). Prov. Nuflo de Chávez, San Andres, $10 \mathrm{~km}$ al oeste de Concepción, 16 56'35"S 62 38'08"W, 503 m, 21 March 2012, J. R. I. Wood Eं D. Soto 27516 (K, LPB, USZ). Prov. Velasco, 3 km de San Juancito cerca de una pequeña comunidad, 16²'13'25"S 6055'20"W, 386 m, 26 April 2009, J. R. I. Wood et al. 26136 (K, LPB, UB, USZ).

CONSERVATION STATUS. Least Concern (LC).

PHENOLOGY. Flowers mostly at the end of the rainy season from February to April.

NOTES. This species is distinguished from Ipomoea sericosepala by the glabrous sepals and we are unaware of other distinguishing features. The two following collections with very sparsely pubescent sepals were made where the range of the two species overlaps and merit further investigation and may be hybrids:

BolıviA. Santa Cruz, Prov. Cordillera, Abapo, c. $35 \mathrm{~km}$ hacia Camiri, $19^{\circ} 07^{\prime} 18^{\prime \prime S} 63^{\circ} 30^{\prime} 29^{\prime \prime} \mathrm{W}, 736 \mathrm{~m}, 8$ Feb. 2008, M. Mendoza et al. 2725 (USZ); Camiri, c. $6.5 \mathrm{~km}$ de Cuevo y $8.4 \mathrm{~km}$ antes del cruce Camiri, $20^{\circ} 24^{\prime} 56^{\prime \prime S} 63^{\circ} 28^{\prime} 43^{\prime \prime W}, 942 \mathrm{~m}, 9$ Feb. 2008, M. Mendoza et al. 2736 (USZ).

10. Ipomoea fimbriosepala Choisy (1845: 559). Type: Cultivated plants from Madagascar, Lindley (syntype CGE 14254) and Mauritius, Bouton s.n. (syntype G00135515).

Twining annual herb, young stems glabrous, older stems setose. Leaves petiolate, $4-9 \times 3-5 \mathrm{~cm}$, narrowly (to broadly) deltoid, base sagittate to hastate, auricles acute to obtuse, glabrous, abaxially paler; petioles $2-7.5 \mathrm{~cm}$. Inflorescence of 1 (-2)-flowered axillary, pedunculate cymes; peduncles $0.5-3.5 \mathrm{~cm}$; bracteoles $8-15 \times 3-5 \mathrm{~mm}$, ovate, acuminate to apiculate, membranous, pale green, moderately persistent; pedicels $1-2.5 \mathrm{~cm}$; outer sepals $13-20 \times 7-$ $10 \mathrm{~mm}$, ovate, apex finely mucronate, base truncate, abaxially 3-winged, the wings smooth or (especially below) dentate, inner sepals c. $5 \mathrm{~mm}$ shorter, unwinged; corolla $2.5-3.5 \mathrm{~cm}$, funnel-shaped, pink, glabrous, limb c. $5 \mathrm{~cm}$ diam., shallowly lobed, the lobes acute. Capsule 12 - $15 \times 12-14 \mathrm{~mm}$, ovoid, glabrous, enclosed by the sepals, seeds $5-6 \mathrm{~mm}$ long, minutely tomentellous. 
DISTRIBUTION \& HABITAT. Widely distributed in tropical America and tropical Africa but scattered in occurrence, the populations usually small and impermanent. In Bolivia an uncommon plant of the eastern lowlands below about $400 \mathrm{~m}$.

SPECIMENS EXAMINED. BOLIVIA. Beni: Prov. Ballivian, Espiritu, 14 March 1990, S. G. Beck 15197 (LPB); ibid., 1406'S 66 22'W, 200 m, 29 Dec. 1998, S. G. Beck 15439 (LPB); Est. Biologica del Beni, 14³0'S 66 37'W, 200 m, 14 Dec. 1994, J. Balderrama 370 (LPB, MO); 15 km $\mathrm{E}$ of San Borja hacia San Ignacio de Moxos, $14^{\circ} 55^{\prime} \mathrm{S}$ 633' W, 200 m, 17 Feb. 1995, M. Moraes Eु Oviedo 1891 (LPB). Prov. Yacumo, Bajio, $70 \mathrm{~km}$ de San Borja hacia Trinidad, $14^{\circ} 50^{\prime} \mathrm{S} 66^{\circ} 05^{\prime} \mathrm{W}, 200 \mathrm{~m}, 19 \mathrm{Feb} .1995$, M. Moraes $\mathcal{E} \sigma^{\circ}$ Oviedo 2021 (LPB). La Paz: Prov. Iturralde, Luisita, $13^{\circ} 05^{\prime} \mathrm{S} 67^{\circ} 15^{\prime} \mathrm{W}, 180 \mathrm{~m}, 29$ Aug. 1985, R. Haase 666 (LPB). Santa Cruz: Prov. Chiquitos, $2 \mathrm{~km}$ NW of Robore, $59^{\circ} 46^{\prime} \mathrm{S}, 18^{\circ} 20^{\prime} \mathrm{W}, 300$ m, 22 April 1980, A. Krapovickas $\mathcal{E}^{\circ}$ A. Schinini 36379 (CTES). Prov.Velasco, $35 \mathrm{~km}$ from Santa Rosa de la Roca towards Piso Firme, 15³9'20"S 61³1'39"W, 405 m, 5 Dec. 2010, J. R. I. Wood et al. 27081 (K, LPB, USZ). CONSERVATION STATUS. Least Concern (LC) based on its extent of occurrence but this is an annual species whose populations are few and impermanent. The record associated with Wood et al. 27081, for example, consisted of a single much branched plant. It could not be refound in succeeding years.

PHENOLOGY. An annual species mostly found in flower during the summer rainy season, often as early as December in this period.

NOTES. Similar to Ipomoea setifera in having sepals in which the veins are extended into wings, these commonly dentate; also in the relatively persistent, pale green membranous sepals but differing in being annual, the bracteoles narrower, the sepals only 3winged and the corolla much shorter. Fruiting specimens can be difficult to distinguish.

11. Ipomoea setifera Poir. (Poiret 1804: 17). Type: Guyana, Brocheton s.n. (holotype P-JU, n.v.).

Trailing or twining herb, stems often roughly hirsute with stiff hairs. Leaves petiolate, $3-9 \times 2-5 \mathrm{~cm}$, ovate-deltoid or subreniform with wide-spreading obtuse or rounded auricles, base broadly cordate, apex obtuse, emarginate and mucronate, less commonly acute or acuminate, glabrous, lower surface paler, reticulate-veined; petioles $1-6 \mathrm{~cm}$, glabrous but often with scattered tubercles. Inflorescence of pedunculate, $1-3(-5)$-flowered, axillary cymes peduncles $(0.3-) 3-5(-8) \mathrm{cm}$, sometimes tubercled; bracteoles $1.2-2 \times 0.6-1.5 \mathrm{~cm}$, ovate, longmucronate, persistent, pale green, concave, concealing the pedicel bases; pedicels $8-28 \mathrm{~mm}$; sepals unequal, glabrous, outer sepals $1.5-2 \mathrm{~cm}$, elliptic, acute, finely aristate, abaxially 5-winged, wings smooth or, often, softly tubercled, inner sepals c. $5 \mathrm{~mm}$ shorter, ovate, pale, unwinged; corolla $5.5-8 \mathrm{~cm}$, funnel-shaped, pink, glabrous, limb c. $4 \mathrm{~cm}$ diam., unlobed. Capsule ovoid, c. $12 \mathrm{~mm}$ long and wide, seeds tomentellous. Fig. 1D.

DISTRIBUTION \& HABITAT. Widely distributed in tropical America and Africa and apparently more common and more permanent everywhere than Ipomoea fimbriosepala. In Bolivia scattered in the eastern lowlands.

SPECIMENS EXAMINED. BoliviA. Beni: Prov. Vaca Diez, just N of Guayaramerin, 12 Feb. 1978, Anderson 12084 (NY). Pando: Prov. Manuripi, Arroyo Bay, 17 Oct. 1989, S. G. Beck et al. 19444 (LPB); Río Manuripi, 6 - $12 \mathrm{~km}$ from Puerto Rico, $11^{\circ} 09^{\prime} \mathrm{S}$ 67³3'W, 278 m, 18 Sept. 1996, A. Paniagua E P. F. Foster 727 (LPB); Río Manuripi, $5 \mathrm{~km}$ from Puerto Rico, $11^{\circ} 08^{\prime} \mathrm{S} 67^{\circ} 33^{\prime} \mathrm{W}, 110 \mathrm{~m}, 19$ Sept. 1996, A. Paniagua E ${ }^{\circ}$. F. Foster 739 (LPB). Santa Cruz: Prov. Germán Busch, Río Paraguay, Bahia Caceres, $19^{\circ} 00^{\prime} \mathrm{S} 57^{\circ} 41^{\prime} \mathrm{W}, 150 \mathrm{~m}, 10$ Sept. 2000, S. G. Beck 27559 (K, LPB). Prov. Guarayos, 6 - $12 \mathrm{~km} \mathrm{E} \mathrm{of}$ Ascención de los Guarayos on road to aserradero La Chonta, $15^{\circ} 45^{\prime} \mathrm{S} 63^{\circ} 01^{\prime} \mathrm{W}, 10$ Aug. 1983, M. Hopkins et al. (LPB); c. $5 \mathrm{~km}$ from Ascención along road to La Chonta, 15 $52^{\prime} 55^{\prime \prime S} 63^{\circ} 07^{\prime} 58^{\prime \prime W}, 216$ m, 23 July 2014, J. R. I. Wood E D. Soto 27932 (LPB, OXF, USZ); Com. Momene, km 280 South of Ascención de Guarayos on road to Santa Cruz, 16 06'36"S 1606'36"W, 244 m, 23 July 2014, J. R. I. Wood Ẽ D. Soto 27934 (K, LPB, OXF, USZ). Prov. Nuflo de Chávez, $30 \mathrm{~km} \mathrm{~S}$ of Concepción, 400 m, 12 Nov. 1994, T. Killeen E J J. Wellens (MO); $40 \mathrm{~km}$ al sur de Concepción sobre el camino a Lomerío, $16^{\circ} 22^{\prime} 43^{\prime \prime S} 61^{\circ} 58^{\prime} 58^{\prime \prime W}, 539 \mathrm{~m}, 30$ May 2008, J. R. I. Wood et al. 24971 (K, LPB, UB, USZ); 45 - $50 \mathrm{~km}$ al sur de Concepción sobre el camino a

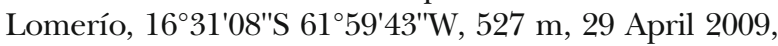
J. R. I. Wood et al. 26213 (K, LPB, USZ); between Santa Ana and Panorama on road from Lomerío to Concepción, 16 31'37"S 6159'41"W, 530 m, 11 April 2013, J. R. I. Wood et al. 27771 (K, LPB, USZ). Prov. Velasco, Río Iténez, $24 \mathrm{~km} \mathrm{~S}$ of Flor de Oro, $60^{\circ} 48^{\prime} \mathrm{S}$, $13^{\circ} 39^{\prime} \mathrm{W}, 200-400$ m, 26 May 1991, M. Peña Ẽ P. F. Foster 347 (F, LPB, USZ); Reserva Forestal Bajo Paraguá, Aserradera Moira, 14 $35^{\prime} 52^{\prime \prime} \mathrm{S}, 61^{\circ} 21^{\prime} 11^{\prime \prime W}, 180 \mathrm{~m}, 11$ May 1994, T. Killeen 6250 (ARIZ, LPB, USZ).

CONSERVATION STATUS. Least Concern (LC).

PHENOLOGY. Found in flower in most months of the year but apparently most commonly in the autumn and winter from April to August.

NOTES. Distinguished from Ipomoea fimbriosepala by the much larger corolla, perennial habit, broader bracteoles which enclose the pedicel bases, and the 5 -winged sepals.

12. Ipomoea procurrens Meisn. (Meisner 1869: 254). Type: Brazil, Minas Gerais, 1845, Widgren 302 (lectotype $\mathrm{BR}$ !, designated here, isolectotypes K!, R!, S). 
Decumbent, ascending or erect plant with xylopodium, stems somewhat woody, glabrous or, especially on young stems, shortly pubescent. Leaves very shortly petiolate, ovate or broadly oblong, apex obtuse and mucronulate, base broadly cuneate to rounded, slightly asymmetric, both surfaces usually glabrous, veins prominent abaxially; petioles $3-8 \mathrm{~mm}$. Inflorescence of pedunculate, 1 - 3-flowered cymes from upper leaf axils; peduncles $2-30 \mathrm{~mm}$, glabrous to densely pubescent, bracteoles $4-5$ $\mathrm{mm}$, narrowly deltoid; pedicels $5-20 \mathrm{~mm}$, longer than peduncles, sometimes muricate; sepals somewhat unequal, outer sepals $7-13 \mathrm{~mm}$, lanceolate to ovate, acuminate to obtuse and mucronate, muricate; inner sepals $11-18 \times 4-6 \mathrm{~mm}$, lanceolate to ovate, obtuse and mucronate; corolla $6-7 \mathrm{~cm}$, funnel-shaped, pink, glabrous, limb c. $5 \mathrm{~cm}$ diam., unlobed. Capsule and seeds not seen. Fig. 3B.

DISTRIBUTION \& HABITAT. A characteristic cerrado species of Central Brazil, Bolivia and Paraguay. In Bolivia it is restricted to the Parque Nacional Noel Kempff Mercado where it is common on the meseta but also found on the Pampas de Los Fierros. Map 9.

SPECIMENS eXAMINed. Bolivia. Santa Cruz: Prov. Velasco, PNNKM, Camp. Huanchaca 1, 13⒌'S $60^{\circ} 43^{\prime} \mathrm{W}, 800 \mathrm{~m}, 3-4$ Dec. 1987, W. W. Thomas et al. 5595 (FTG, NY); ibid., $1.5 \mathrm{~km} \mathrm{~S}$. of Camp. Huanchaca 1, $13^{\circ} 54^{\prime} 22^{\prime \prime} 60^{\circ} 48^{\prime} 52^{\prime \prime}, 450 \mathrm{~m}, 12$ May 1994, B. Mostacedo et al. 1666 (MO); ibid., 16 May 1994, B. Mostacedo et al. 1828 (USZ); Camp. (viejo) Los Fierros, $13^{\circ} 54^{\prime} 22^{\prime \prime S} 60^{\circ} 48^{\prime} 52^{\prime \prime} \mathrm{W}, 400 \mathrm{~m}$, 20 May 1994, B. Mostacedo Eै C. Cabrera 2008 (USZ); Las Gamas, $14^{\circ} 49^{\prime} \mathrm{S} 60^{\circ} 23^{\prime} \mathrm{W}, 900 \mathrm{~m}$, 28 March 1993, T. J. Killeen et al. 4825 (USZ); ibid., 14 48'05"S $60^{\circ} 23^{\prime} 42^{\prime \prime W}, 825 \mathrm{~m}, 11$ June 1994 E. Gutiérrez et al. 1418 (MO); Camp. Huanchaca 2, 14 31'27"S $60^{\circ} 44^{\prime} 40 " \mathrm{~W}, 600 \mathrm{~m}, 8$ March 1997, S. Jiménez E E E. Gutiérrez 1273 (USZ); $1 \mathrm{~km}$ SW of Camp. Huanchaca 2, $14^{\circ} 32^{\prime} \mathrm{S} 60^{\circ} 44^{\prime} \mathrm{W}, 750 \mathrm{~m}, 20$ April 2002, J. R. I. Wood et al. 18226 (K, LPB, USZ); Camp. Huanchaca 2, 14 ${ }^{\circ} 30^{\prime} 30^{\prime \prime} \mathrm{S} 60^{\circ} 40^{\prime} 59^{\prime \prime} \mathrm{W}, 725 \mathrm{~m}, 4$ Nov. 2008, J. R. I. Wood et al. 25231 (K, LPB, UB, USZ); entre las palmeras y Huanchaca 2, $14^{\circ} 31^{\prime} 55^{\prime \prime S} 60^{\circ} 44^{\prime} 24^{\prime \prime} \mathrm{W}$, 750 m, 3 Dec. 2010, J. R. I. Wood et al. 27019 (K, LPB, USZ).

CONSERVATION STATUS. Data deficient (DD) but probably Least Concern (LC). It appears to be common in the Noel Kempff National Park.

PHENOLOGY. Flowers throughout the summer rainy season from November to May.

NOTES. Although rather variable in habit and in leaf and sepal shape this species is usually recognised easily by the shortly petiolate, oblong to ovate leaves with a cuneate base and the distinctive muricate outer sepals.
13. Ipomoea paludicola J. R. I. Wood $\mathcal{E} R$. W. Scotland, nom. nov.

http://www.ipni.org/urn:lsid:ipni.org:names:77148115-1

Basionym: Ipomoea serpens Meisn. (Meisner in Martius, Flora Brasiliensis 7: 275 (1869)). Type: Brazil, Minas Gerais, Rio das Velhas, Pohl 3173 (lectotype W 0052417, designated here, isolectotype W 0052416), non L. (Linnaeus 1759).

Erect, twining or trailing herb, glabrous in all vegetative parts; rootstock stout and somewhat tuberous; stems slightly succulent, often rooting at nodes. Leaves petiolate, sagittate, often strongly so, the auricles linear to lanceolate, acuminate or less commonly, rounded, $2-4 \times 0.2-6 \mathrm{~cm}$, the blade (excluding auricles) $2.5-7.5 \times(0.1-) 1.7-1.9 \mathrm{~cm}$, lanceolate, narrowly to broadly oblong or oblong-elliptic, apex obtuse and mucronulate, green on both surfaces but somewhat darker adaxially; petioles $2-5 \mathrm{~cm}$. Inflorescence of shortly pedunculate, axillary cymes, often reduced to a single flower; peduncles $0.5-3.5 \mathrm{~cm}$; bracteoles $1-1.5 \times$ $0.2 \mathrm{~mm}$, deltoid, caducous; pedicels $8-15 \mathrm{~mm}$; sepals very unequal, outer sepals $4-7 \times 3-3.5 \mathrm{~mm}$, oblong, obtuse to rounded, mucronate, the mucro deciduous, dark green, often transversely muricate, margin scarious, inner sepals much larger, $8-14 \times 5 \mathrm{~mm}$, broadly oblong-obovate, rounded or retuse and mucronulate, the mucro deciduous, conspicuously pallid and subscarious; corolla $7-8.5$ $\mathrm{cm}$, pink, glabrous, funnel-shaped, limb $4-5 \mathrm{~cm}$ diam., unlobed; stamens included, filaments unequal, glabrous apart from the fleshy hairs on the basal expanded part, shorter filaments $10-11 \mathrm{~mm}$, longer $16-17 \mathrm{~mm}$, anthers linear, $4 \times 0.5 \mathrm{~mm}$; style $2.4-2.6 \mathrm{~cm}$, persistent, glabrous. Capsule $8 \times 8 \mathrm{~mm}$, ovoid, glabrous; seeds $4.5 \times 3 \mathrm{~mm}$, blackish, minutely puberulent. Figs 3A, 4 .

DISTRIBUTION \& HABITAT. Common in Bolivia on seasonally flooded plains in parts of the Beni, the Río Paraguá basin around the Noel Kempff Park and in Brazil in the Pantanal. It also extends along the Río Paraguay into Paraguay and occurs in Minas Gerais and Bahia states in Brazil as well as in Venezuela and north to Costa Rica. It may be more widespread than the following records suggest.

SPECIMENS EXAMINED. BoliviA. Beni/Santa Cruz: "Trinidad - Mission Guarayos", 250 m, Sept. 1926, E. Werderman 2324, (LPB, NY). Beni: Prov. Ballivian, Espiritu, zona de Río Yacuma, Tajibal de Lucumo(s), 1 Oct. 1986, S. G. Beck 2612 (LPB); ibid., 8 April 1980, S. G. Beck 3238 (FTG, LPB); ibid., 13 April 1981, S. G. Beck 5357 (LPB); ibid., 28 Aug 1986, S. G. Beck 5720 (LPB); ibid., 20 March 1990, S. G. Beck 15240 (LPB); ibid., 31 Aug. 1986, M. Sigle 3 (LPB); $10 \mathrm{~km}$ NNW of Santa Rosa on road from Rurrenabague to Riberalta, $15^{\circ} 54^{\prime} \mathrm{S} 66^{\circ} 51^{\prime} \mathrm{W}, 190 \mathrm{~m}, T$. B. Croat et al. 84605 (ARIZ, MO). Prov. Cercado, Terr. Siriano, $14^{\circ} 50^{\prime} \mathrm{S} 64^{\circ} 17^{\prime} \mathrm{W}, 160 \mathrm{~m}, 30 \mathrm{March} 1992$, Chomono 

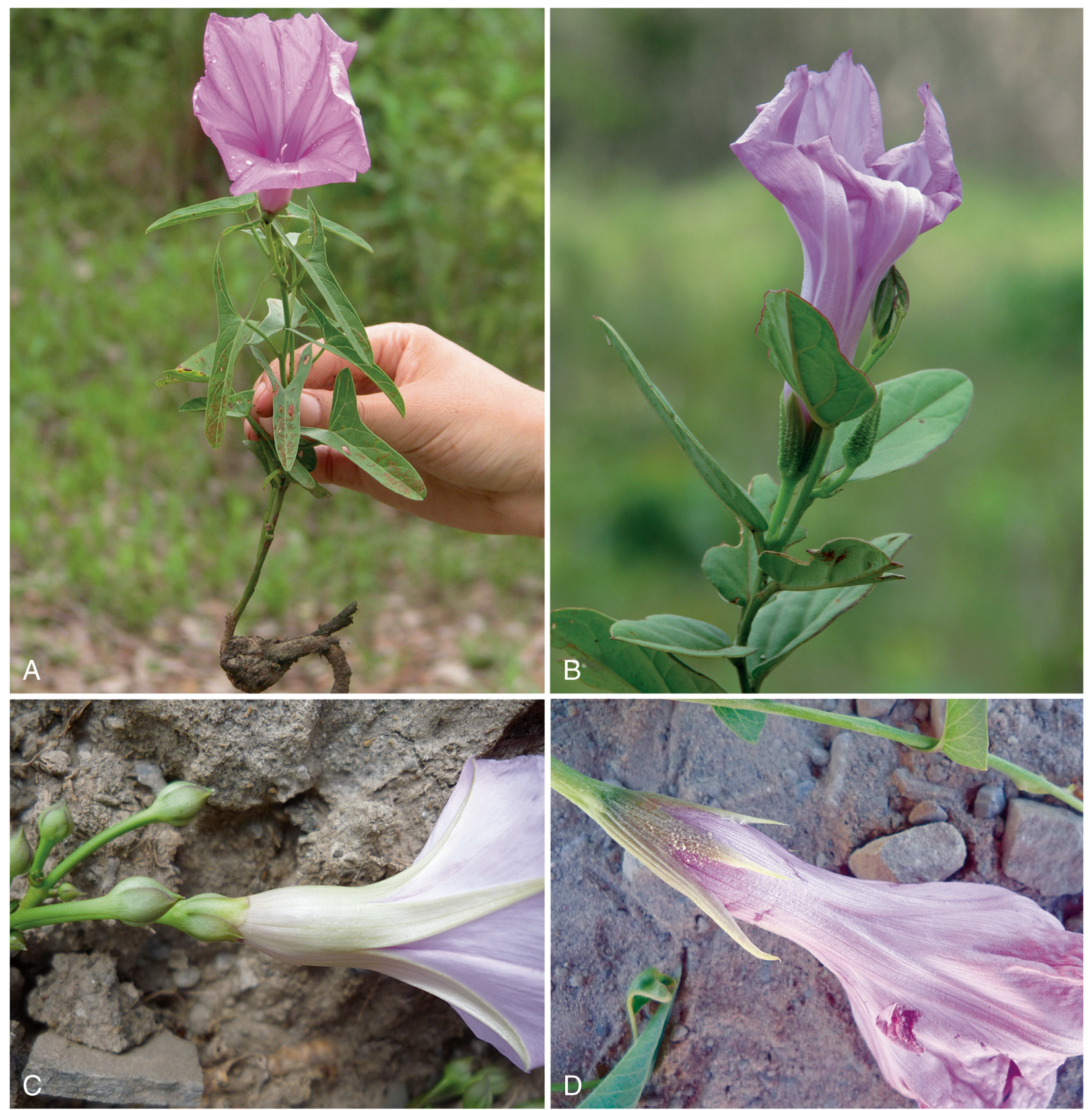

Fig. 3. A Ipomoea paludicola; B I. procurrens; C I. amnicola; D I. incarnata. PHOTOS: A, B DARWIN INITIATIVE PROJECT 16-004; C, D BETH WILLIAMS.

E Saavedra 36 (LPB); $2 \mathrm{~km}$ de Sachoere hacia Loreto, $14^{\circ} 58^{\prime} \mathrm{S} 64^{\circ} 45^{\prime} \mathrm{W}, 5$ June 1999, Orellano Ẽ S. G. Beck 236 (LPB). Prov. Yacuma, Santa Ana de Yacuma, entre San Carlos y Río Yañes, $13^{\circ} 05^{\prime} 40^{\prime \prime} \mathrm{S} 65^{\circ} 42^{\prime} 32^{\prime \prime} \mathrm{W}, 230 \mathrm{~m}$, March 2006, M. Atahuachi et al. 985 (BOLV, LPB). Santa Cruz: Prov. Velasco, El Refugio, 1447'09"S 6102'52"W, 150 m, 21 May 1994, R. Guillén Ẽ R. Choré 1446 (ARIZ, MO, USZ); El Refugio, W side of Río Paragua, 1446'18"S 61 02'19"W, 176 m, 21 April 2004, J. R. I. Wood E $H$. Huaylla 20763 (HSB, K, LPB, USZ); Cruce de Toledo al Refugio, en el camino entre San José Campamento y
Florida, 1454'41"S 61 $08^{\circ} 58^{\prime \prime W}, 175$ m, 9 Nov. 2009, J. R. I. Wood et al. 26398 (K, LPB, USZ); Pampas de El Toledo, Alto Río Paragua, 1443'22"S 6108'28"W, 354 m, 19 Jan. 2014, J. R. I. Wood E D. Soto 27913 (LPB, USZ); Campos de San Ramón, 14²10'30"S 61 23'W, 230 m, 8 10 Aug. 1995, S. R. P. Halloy et al. 4307 (NY).

BRAZIL. Sin data, Pohl 1754 (K). Amazonas, Manaos, May 1909, E. Ule 8955 (K). Bahia: 3 km de Campo Alegre de Lourdes, entrando para Remansa, 9³6'43"S 4256'49"W, 456 m, 15 June 2001, Nunes et al. 420 (HUEFS). Mato Grosso: Mun. Caceres, Pantanal, 1976, 


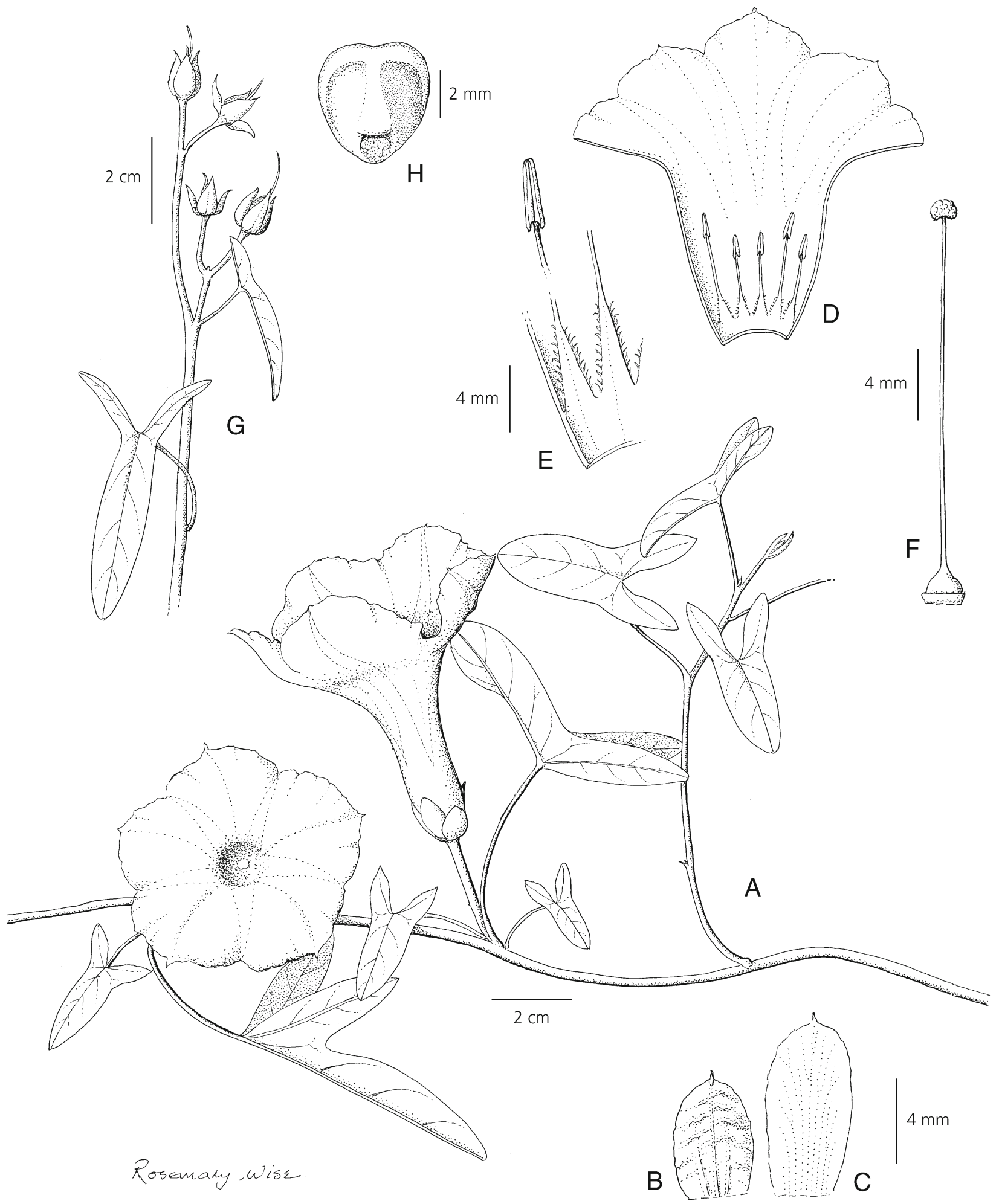

Fig. 4. Ipomoea paludicola. A habit; B outer sepal; $\mathrm{C}$ inner sepal; D corolla opened out to show stamens; $\mathrm{E}$ detail of anther and filament base; F ovary and style; G shoot with fruiting inflorescence; H seed. A - F from Wood \& Huaylla 20763, G - H from Guillén \& Choré 1446. DRAWN BY ROSEMARY WISE.

Dobreimer Ẽ Tokarnia 1255 (R). Mato Grosso do Sul: Mun. Corumbá, Estrada MT 732, a Curva de Leque, 85 m, 19 ${ }^{\circ} 11^{\prime} \mathrm{S} 57^{\circ} 01^{\prime} \mathrm{W}, 3$ March 1986, A. Pott et al. 2436 (MBM); Mun. Poconé, Estrada Transpantaneira, 105 m, 
16²9'S 56² 42'W, 18 May 1989, A. Pott et al. 4808 (MBM); Mun. Poconé, Reiro Santa Isabel, Faz. Porto Jofre, $90 \mathrm{~m}$, $18^{\circ} 49^{\prime} \mathrm{S} 56^{\circ} 47^{\prime} \mathrm{W}, 6$ Oct. 1989, A. Pott 5036 (CPAP, MBM); Mun. Corumba, Esquina do Leque, $19^{\circ} 14^{\prime} \mathrm{S} 57^{\circ} 03^{\prime} \mathrm{W}, 5$ April, 1990, A. Eं V. J. Pott 7678 (CPAP); ibid., V. J. Pott et al. 1353 (CPAP); Mun. Poconé, Vazante Pirici, Faz. Ibiranga, 16³4'S 56 55'W, 3 Aug. 1992, V. J. Pott et al. 1716 (CPAP); Mun. Poconé, km 16.9 between Poconé and Porto Cercado, 110 m, 30 May 1992, M. Schessi 2634 (FTG), Mun. Santo Antonio de Leverger, towards Barao de Melgaco, near Río Arica, 1553'S 56 03'W, 22 April 1993, V.J. Pott et al. 2061 (CPAP); Mun. Pocone, Estrada Transpantaneira, $1 \mathrm{~km}$ de Porteira do Ibama, 16 23'39"S 56 39'47"W, 29 Feb. 1996, V. J. Pott et al. 3034 (CPAP). Minas Gerais. Rio Das Velas, Pohl 2173; 2 km de Januaria, 30 Nov. 1953, Merdes Maghalães 6087 (RB); Itacarambi, 20 April 2007, O. S. Ribas E J. M. Silva 7772 (MBM); between Corrente and Cristolandia, A. Fernandes $\mathcal{E}$ Matos (RB). PARAguAY. Villa Socna, north Paraguay, between Río Apa and Río Aquidaban, 1908 - 9, K. Fiebrig 5008 (K, P). San Pedro, Distr. Lima, Estancia Carumbe, 1 Dec. 1969, T. M. Pedersen 9460 (MBM); around 25 Diciembre, 2442'07"S 56 30'31"W, 24 June 2001, E. Zardini E M. Vera 56677 (ARIZ, MO); ibid., E. Zardini E M. Vera 56716 (ARIZ, MO); ibid., E. Zardini E M. Vera 56744 (ARIZ, MO); around Rosario, 2422'39"S 5706'16"W, 25 June 2001, E. Zardini E L. Guerrero (ARIZ, MO). Paraguaria, 1901/2, Hassler 7680 (BM). Cordillera, Caacupé, $47 \mathrm{~km}$ W de Caacupé, $350 \mathrm{~m}, 19$ Oct. 1999, F. de la Puente 3599 (CIP-Lima). GUYANA. Rapununi R., Dadanawa, 249'N 59 $32^{\circ} \mathrm{W}, 120$ m, 27 Sept. 1997, M. L. Jansen-Jacobs et al. 5612 (ARIZ, P). VenezuelA. Apure: entre el Samán y el Mantecal, Est. Biológica "El Frio", Oct. - Nov. 1976, S. Castroviejo है Ginés López 142 (MA), ibid., S. Castroviejo Ẽ Ginés López 254 (MA); Bolivar: Est. Bolivar, W Sierra Imataca, El Palmar, Hac. Costa Rica, 270 m, 10 April 1988, C. Sastre et al. 8558 (P). COSTA RICA. Guanacaste, Cantón de la Cruz, de Bahia Salinas a Santa Cecilia, $11^{\circ} 02^{\prime} 20^{\prime \prime} \mathrm{N}$ 85³2'30"W, 270 m, 6 Feb. 1996, E. López Ẽ M. Segura 92 (MO, K).

\section{CONSERVATION STATUS. Least Concern (LC).}

PHENOLOGY. In Bolivia flowers mostly in the winter dry season from around May to November as water recedes from the flooded pampas.

NOTES. This species has usually been included within Ipomoea asarifolia, as in Wood et al. (2015: 524), and is clearly closely related but is easily distinguished by the sagittate rather than suborbicular, reniform leaves. It was described as $I$. serpens by Meisner as noted by O'Donell (1952: 242) but this name is illegitimate and has generally been treated as a synonym of $I$. maurandioides. Molecular studies (Williams et al. in prep.) suggest that I. paludicola is sister to I. procurrens, being more closely related to that species than to I. asarifolia. It is interesting that all three species commonly have transversely muricate sepals, although this is most obvious in I. procurrens. Various forms of I. paludicola can be encountered. Where it is growing among bushes it occurs as a climbing plant. On open flood plain it is usually trailing and rooting at the nodes, but erect flowering specimens occur during the dry season.

Amongst Bolivian plants it is distinctive for its sagittate leaves, very unequal sepals, the outer commonly muricate, and for being quite glabrous.

14. Ipomoea amazonica (D. F. Austin E Staples) J. R. I. Wood E R. W. Scotland, comb. nov.

http://www.ipni.org/urn:lsid:ipni.org:names:77148116-1

Turbina amazonica D. F. Austin \& Staples, Bull. Torrey Bot. Club 118 (3): 270 (1991). Type: Brazil, Amapá, D. F. Austin, C. E. Nauman, B. Rabelo, C. Rosário Eं M. R. Santos 7389 (holotype MG; isotypes FAU, now in FTG!, NY!, US!).

Twining perennial, stem tomentose. Leaves petiolate, 3.5 $-9 \times 3-7 \mathrm{~cm}$, ovate-deltoid, obtuse and mucronate, base cordate with narrow sinus and rounded auricles, margin slightly undulate, softly tomentose on both surfaces, abaxially grey, petioles $1-2 \mathrm{~cm}$, tomentose. Inflorescence a dense cluster of up to 10 flowers at apex of a long peduncle; peduncles $3-10 \mathrm{~cm}$, tomentose; bracteoles 5 - 13 mm long, ovate-rhomboid, tomentose, persistent; pedicels $5-10 \mathrm{~mm}$; sepals tomentellous, accrescent in fruit, unequal, outer $8-12 \times 5-8 \mathrm{~mm}$, oblong-ovate, acute, base subcordate, inner $5-8 \mathrm{~mm}$, oblong-ovate with broad chartaceous margins; corolla magenta, 5 $6 \mathrm{~cm}$ long, funnel-shaped, glabrous except for a few hairs at apex of midpetaline bands in bud, limb c. $3 \mathrm{~cm}$ diam. Capsule ovoid; seeds reported as usually one.

DISTRIBUTION \& HABITAT. A rare species of seasonally flooded areas in the Amazon basin in Bolivia and Brazil. In Bolivia it is recorded from Pando, Iturralde and The Noel Kempff National Park region. It may be more common in the Amazonian regions of both Bolivia and Brazil than the few collections suggest.

SPECIMEnS EXAMIned. BOlIVIA. La Paz: Prov. Iturralde, Pampas del Madidi, N side of Río Madidi, $15.6 \mathrm{~km} \mathrm{NE}$ of confluence with Río Inambari, $12^{\circ} 55^{\prime} 39^{\prime \prime S}$ 6747'19"W, $180 \mathrm{~m}, 26$ May 2009, B. M. Torke et al. 540 (LPB). Pando: Prov. Abuna, Río Negro, close to junction with Río Abuna, $9^{\circ} 50^{\prime} \mathrm{S} 65^{\circ} 40^{\prime} \mathrm{W}, 100 \mathrm{~m}, 8$ July 1992, A. Gentry E̋ A. Perry 77997 (LPB , MO). Prov. Federico Roman, Río Negro, tributario del Río Abuna, $9^{\circ} 52^{\prime} \mathrm{S} 65^{\circ} 42^{\prime} \mathrm{W}, 150 \mathrm{~m}, 15$ July 1992, L. Vargas et al. 980 (F). Santa Cruz: Prov. Velasco, Campos de San Ramón, $14^{\circ} 10^{\prime} 30^{\prime \prime S} 61^{\circ} 23^{\prime} \mathrm{W}, 230$ m, 9 Aug 1995, S. R. P. Halloy 
et al. 4291 (NY); PNNKM, Lago Caiman, 13³5'01"S 6056'18"W, 25 June 1998, N. Ritter et al. 4348 (MO); ibid., N. Ritter et al. 4350 (MO).

CONSERVATION STATUS. Using Geocat and based on the extent of its occurrence this species comes out as Near Threatened (NT) in Bolivia. However, given our lack of information on its known populations and the poor knowledge of the Bolivian Amazonian region in general it is best classified as Data Deficient (DD). PHENOLOGY. In Bolivia it has been found in flower from June to August during the winter dry season. NOTES. Very distinctive because of its rather small velvety leaves and oblong-cordate velvety sepals and persistent bracteoles.

15. Ipomoea procumbens Mart. ex Choisy (1845: 351). Type: Brazil, Minas Gerais, Martius 593 (holotype M-0184989!).

Prostrate (or twining) herb, glabrous or nearly so in all parts, stems somewhat woody. Leaves shortly petiolate, $4-11 \times 0.2$ $-1.5 \mathrm{~cm}$, narrowly oblong to oblong-elliptic or oblanceolate, acute, base attenuate, cuneate or broadly cuneate, petioles 5-10 $\mathrm{mm}$. Inflorescence of solitary or paired, pedunculate, axillary flowers; peduncles $0.5-3.5 \mathrm{~cm}$; bracteoles $2 \mathrm{~mm}$, scale-like, caducous; pedicels $7-12 \mathrm{~mm}$, thickened upwards; sepals unequal, scarious-margined, outer 9 - $11 \mathrm{~mm}$, ovate or oblong-ovate, acute to obtuse and mucronate, inner $12-15 \mathrm{~mm}$, oblong-elliptic, acute or obtuse; corolla $5.5-9 \mathrm{~cm}$, funnel-shaped, gradually widened from a narrow base, pink, glabrous, limb unlobed, c. $3.5 \mathrm{~cm}$ diam. Capsule and seeds not seen.

DISTRIBUTION \& HABITAT. Locally common in the cerrados of Brazil and Paraguay, this is a rare species in Bolivia known from a single collection on the meseta of Caparuch in the Noel Kempff Park, very close to the border with Brazil.

SPECIMENS EXAMINED. BOLIVIA. Santa Cruz: Prov. Velasco, PNNKM, Las Gamas, 1448'17"S, 60²3'14'W, 850 m, 17 Feb. 1997, Guardia et al. 196 (USZ).

CONSERVATION STATUS. The Bolivian population is an outlying colony from the main populations in Brazil. No information is available about the size of the Bolivian population but it lies within a protected area and faces no current, obvious threat. Without further information it can only be classified as Data Deficient (DD).

PHENOLOGY. Found in flower in February.

NOTES. Distinguished by the linear or oblong leaves which taper at the base. The corolla and sepals are similar to those of Ipomoea maurandioides.

16. Ipomoea philomega (Vell.) House (1908: 246). Convolvulus philomega Vell. (Vellozo 1825 [publ. 1829]: 74). Type: Vellozo, Fl. Flumin. 2 t. 63 (1827 [publ. 1831]), lectotype, designated by D. Austin 1982).
Ipomoea cardiosepala Meisn. (Meisner 1869: 265). Type: Brazil, Rio de Janiero, Burchell 1865 (holotype BR, isotype $\mathrm{K}$ !).

Liana to $10 \mathrm{~m}$; stems thick, woody, glabrous. Leaves petiolate, $7-13 \times 7-12 \mathrm{~cm}$, broadly ovate, shallowly cordate with rounded auricles, apex acute or shortly acuminate, shortly mucronate, adaxially glabrous, abaxially thinly pubescent, or glabrous; petioles $6-10$ $\mathrm{cm}$. Inflorescence of many-flowered, pedunculate axillary cymes, these often appearing paniculate or racemose with peduncle extended to form a central rhachis; peduncle $3-$ $20 \mathrm{~cm}$ long, stout, glabrous; bracteoles $17-19 \times 3-8 \mathrm{~mm}$, oblong to narrowly obovate, acute, deciduous; secondary peduncles $1-3 \mathrm{~cm}$; pedicels $5-30 \mathrm{~mm}$, thickened upwards; sepals subequal, glabrous or (rarely) pubescent, $12-17 \times 10-14 \mathrm{~mm}$, outer oblong-elliptic, rounded, often reddish, inner obovate with scarious margins; corolla 5-6 $\mathrm{cm}$, deep pink, glabrous, narrowly funnel-shaped with a narrow tube which is slightly constricted below limb, limb c. $4 \mathrm{~cm}$ diam., unlobed. Capsule ovoid, $13 \times 10 \mathrm{~mm}$, glabrous; seeds $6 \times 3 \mathrm{~mm}$, woolly.

DISTRIBUTION \& HABITAT. Ipomoea philomega is a plant of moist rainforest throughout the neotropics. In Bolivia it has only been found in the Chaparé region, some moist areas of the Yungas and in Pando department. It may have been undercollected because it flowers during the rains when few botanists visit these regions. Map 6 .

SPECIMENS EXAMINED. BOLIVIA. Beni: Prov. Ballivian/ Yacuma, Est. Biológica del Beni, 14³0'S 66 30'W, 17 Jan. 1995, E. Rivero 256 (K, LPB, SP). Prov. Ballivian, Misión Fatima, 240 m, 18 May 1988, S. G. Beck et al. 16643 (LPB, SP). Cochabamba: Prov. Carrasco,

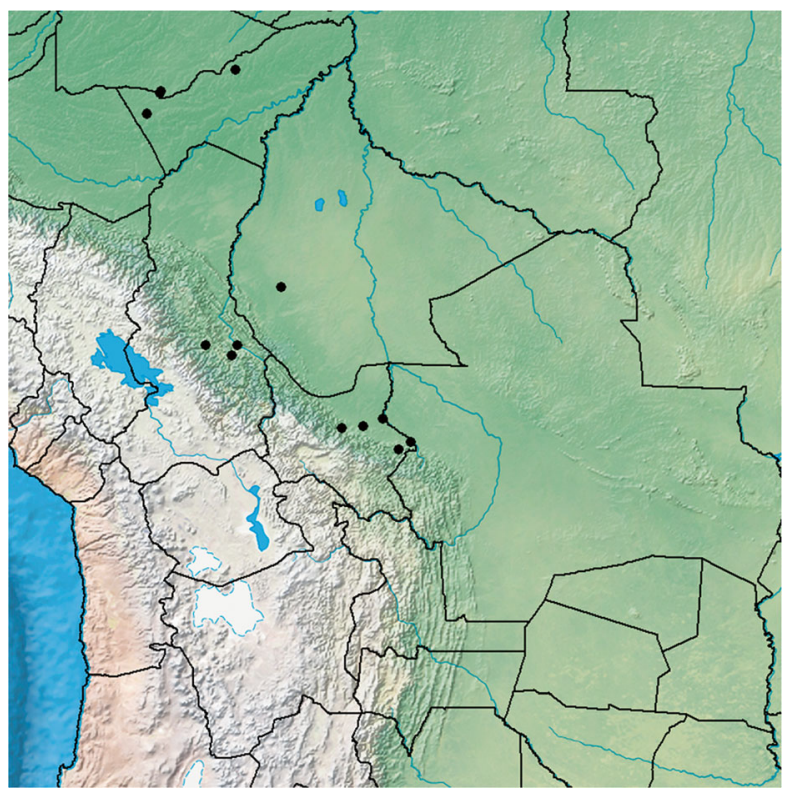

Map 6. Distribution of Ipomoea philomega (O), a lowland moist forest species, almost certainly undercollected. 
Chimore, 550 m, 10 March 1939, W. J. Eyerdam 24835 (F); Puerto Villarroel, 300 m, 30 Dec. 1982, F. Fernandez Casas 7914 (NY, MO); PN Carrasco, Camp. Colomelin, Río Ichoa, 17²4'05"S 64³1'18'W, 12 Jan. 2006 O. Colque 378 (MO, OXF, USZ); Prov. Chapare, c. $0.5 \mathrm{~km} \mathrm{E}$ of Las Avispas along road to Villa Tunari, $17^{\circ} 01^{\prime} \mathrm{S} 65^{\circ} 32^{\prime} \mathrm{W}, 250$ m, 19 Jan. 2005, J. R. I. Wood 21400 (BOLV, K, LPB). La Paz: Prov. Caranavi, Caranavi - Alto Beni, c. $1 \mathrm{~km}$ above Carrasco hacia Bellavista, 900 m, 5 May 1989, S. G. Beck 17205 (K, LPB, SP). Prov. Larejaca, Mapiri, San Carlos, 650 m, 14 Jan. 1927, O. Buchtien 1219 (LPB, US); Prov. Sud Yungas, Alto Beni, camino Sapecho-Santa Ana, 470 m, 21 May 1988, R. Seidel E̋ Schulte 2424 (K, LPB). Pando: Prov. Manuripi, Santa Rosa, 22 March 1956, E. de la Sota 925 (LIL). Prov. Suárez, Cobija, Río Acre, Jan. 1912, Ule 9703 (K); near Cobija airport, 8 Jan. 1983, F. Fernandez Casas $\mathcal{E}^{\circ}$ A. Susanna 8086 (G, MO, NY); Est. Biol. Tahuamanu, $4 \mathrm{~km} \mathrm{NW}$ de Rutina, $11^{\circ} 24^{\prime} \mathrm{S} 69^{\circ} 01^{\prime} \mathrm{W}, 280 \mathrm{~m}, 11$ March 2000, Anderson 161 (LPB). Santa Cruz: Prov. Ichilo, $1-1.5 \mathrm{~km}$ ENE of Río Ichilo bridge on road to

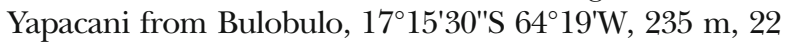
Dec. 1995, M. Nee 46450 (MO, NY, USZ).

CONSERVATION STATUS. Least Concern (LC).

PHENOLOGY. Most commonly found in flower in December and January.

NOTES. A vigorous liana reaching at least $10 \mathrm{~m}$ in height, this species is usually easily identified by its woody stems (and peduncles), abaxially pubescent leaves and relatively small corolla. The elliptic, rounded, often reddish sepals are especially distinctive. It is most likely to be confused with Ipomoea chondrosepala but the inflorescences are many-flowered, often paniculate in form, the flower buds are always glabrous, the corolla shorter and often slightly constricted below the limb and the sepals often reddish.

17. Ipomoea chiliantha Hallierf. (1899b: 50). Type: Lorentz s.n. (holotype $\mathrm{B} \uparrow$, lectotype GOET, designated here).

Twining or trailing perennial, all vegetative parts glabrous. Leaves petiolate, ovate but usually constricted in the middle to form a tapering acuminate apical portion, base cordate with rounded auricles, petioles $3-5 \mathrm{~cm}$. Inflorescence of long pedunculate, axillary cymes, sometimes compounded; peduncles $5-13 \mathrm{~cm}$, bracteoles $2-3 \mathrm{~mm}$, lanceolate, caducous, secondary peduncles $0.5-2 \mathrm{~cm}$; pedicels $1-2.5 \mathrm{~cm}$; sepals unequal, outer $5 \mathrm{~mm}$ long, elliptic, obtuse and mucronulate, inner $6-7 \mathrm{~mm}$, broadly ovate-elliptic, rounded, scarious-margined; corolla $4-5.5 \mathrm{~cm}$, funnelshaped, pink, darker in the centre, glabrous, limb 3 $3.5 \mathrm{~cm}$ diam. Capsule $7 \times 6 \mathrm{~mm}$, ovoid, shortly rostrate, glabrous; seeds (immature), pubescent on the angles.

TYPIFICATION. Three syntypes were given by Hallier, Lorentz s.n. (B, GOET), Balansa 1067 (G) and Hassler
1856 (G). As Hallier worked at Berlin we would assume that the description was based primarily on the Lorentz collection in Berlin. This was destroyed in 1943 so we have selected the duplicate of this at Göttingen (GOET) as lectotype. This is not a very good specimen but the sheet is annotated by Hallier. The Paris specimen of Balansa 1067 is excellent.

DISTRIBUTION \& HABITAT. This species seems to prefer seasonally flooded swampy ground both in Bolivia and Paraguay. It appeared in enormous abundance in ditches and on roadsides in the swampy area east of Yacuses after the construction of the new road but with the growth of grasses and shrubs it has now disappeared.

SPECIMENS EXAMINed. BoliviA. Beni: Prov. Cercado, $2 \mathrm{~km}$ below Puerto Varodor on Río Mamoré, $14^{\circ} 50^{\prime} \mathrm{S}$ $65^{\circ} 01^{\prime} \mathrm{W}, 150 \mathrm{~m}, 30$ Oct. 1998, Maldonado et al. 58 (LPB). Santa Cruz: Prov. Chiquitos, between Quimome and El Tinto, 1741'09"S 61 ${ }^{\circ} 23^{\prime} 30^{\prime \prime} \mathrm{W}, 274$ m, 21 April 2013, J. R. I. Wood E B. Williams (K, LPB, OXF, USZ). Prov. Germán Busch, carretera nueva, entre Yacuses y Puerto Suárez, 1900'09"S 5804'40"W, 99 m, 24 Nov. 2008, J. R. I. Wood E D. Villarroel 25541 (K, LPB, UB, USZ). Prov. Ñuflo de Chávez, Pascana Ministro, $50 \mathrm{~km}$ E of Cuatro Cañadas y $30 \mathrm{~km}$ SE of San Miguelito, $17^{\circ} 05^{\prime} \mathrm{S} 61^{\circ} 47^{\prime} \mathrm{W}, 300 \mathrm{~m}, 12$ June 1995, J. R. Abbott 16966 (BOLV, HSB, LPB, MO, USZ); Puente San Miguelito, $17^{\circ} 01^{\prime} \mathrm{S} 61^{\circ} 51^{\prime} \mathrm{W}, 273 \mathrm{~m}, 10$ April 2013, J. R. I. Wood et al. 27743 (K, LPB, OXF, USZ).

CONSERVATION STATUS. Based on its extent of occurrence in Bolivia this species might be considered Near Threatened (NT), but it occurs in neighbouring countries and may well be under-recorded. It should be provisionally classified as Data Deficient (DD) but will probably prove to be Least Concern (C).

PHENOLOGY. Has been found in flower in many different seasons.

NOTES. Ipomoea chiliantha differs from I. amnicola in the $4-5.5 \mathrm{~cm}$ corolla, less concave outer sepals and slightly longer inner sepals usually $6-7 \mathrm{~mm}$ in length. The longer peduncles may not be significant.

Ipomoea chiliantha has the appearance of a largeflowered I. amnicola and intermediates occur particularly in the Corumbá region. Parada 947 (USZ, MO, OXF) from Carmen Rivero Tórrez is an example from Bolivia but the intermediates appear more commonly in the Brazilian pantanal.

18. Ipomoea amnicola Morong in Morong \& Britton (1892: 170). Type: Paraguay, banks of the Pilcomayo, T. Morong 974 (holotype NY!, isotype R!).

Somewhat succulent twining perennial, completely glabrous in all parts. Leaves petiolate, $2-8(-12) \times 2-8$ $(-10) \mathrm{cm}$, ovate, sometimes broadly so, distinctly narrowed to an acuminate apex, base cordate with 
rounded auricles, abaxially slightly glaucous, petioles $1-10 \mathrm{~cm}$. Inflorescence of rather dense, many-flowered, pedunculate simple or compound cymes; peduncles 1 $5 \mathrm{~cm}$; bracteoles $1-2 \mathrm{~mm}$, ovate, caducous; secondary peduncles $5-15 \mathrm{~mm}$; pedicels $0.8-2 \mathrm{~cm}$; sepals slightly unequal, coriaceous, glabrous, outer $4-5 \mathrm{~mm}$ long, elliptic, concave, obtuse and shortly mucronate, inner 5 - $5.5 \mathrm{~mm}$ long, obovate, rounded, with broad scarious margins; corolla $2-3 \mathrm{~cm}$, pale lilac with dark centre, glabrous, funnel-shaped, the limb $2.5-3 \mathrm{~cm}$ diam., unlobed. Capsule ovoid, $9-12 \times 6 \mathrm{~mm}$, glabrous, seeds reddish brown, tomentose. Fig. 3C.

DISTRIBUTION \& HABITAT. A species with an amphitropical distribution being found in the southern United States and from Colombia south to Argentina in South America. In Bolivia it is most common in the Chaco and, when found elsewhere, is an indicator of chaco-like conditions in the dry inter-Andean valleys both in the Río Grande catchment area and in the Yungas of La Paz. It is a plant of scrub sometimes festooning bushes preferring areas which may be seasonally wet but dry most of the year. Map 7 .

SELECTED SPECIMENS OF 33 EXAMINED. BOLIVIA. Chuquisaca: Prov. Luis Calvo, $100 \mathrm{~km} \mathrm{E}$ of Boyuibe, 19 June 1992, B. Mostacedo E T. J. Killeen 354 (LPB, NY, USZ). Prov. Oropeza, Hac. Charobamba, 1475 m, 23 June 1989, Muñoz 172 (HSB, LPB). Prov. Zudañez, $10-15 \mathrm{~km}$ del Puente Inca hacia Zudañez, camino de Pasorapa a Mojocollo, 1843'34"S 61³1'34"W, 1353 m, 31 March 2013, J. R. I. Wood et al. 27724 (K, LPB, USZ). Cochabamba: Prov. Campero, Quinori-Vallegrande near confluence of Río Mizque and Río Grande, 30 Jan. 1993,

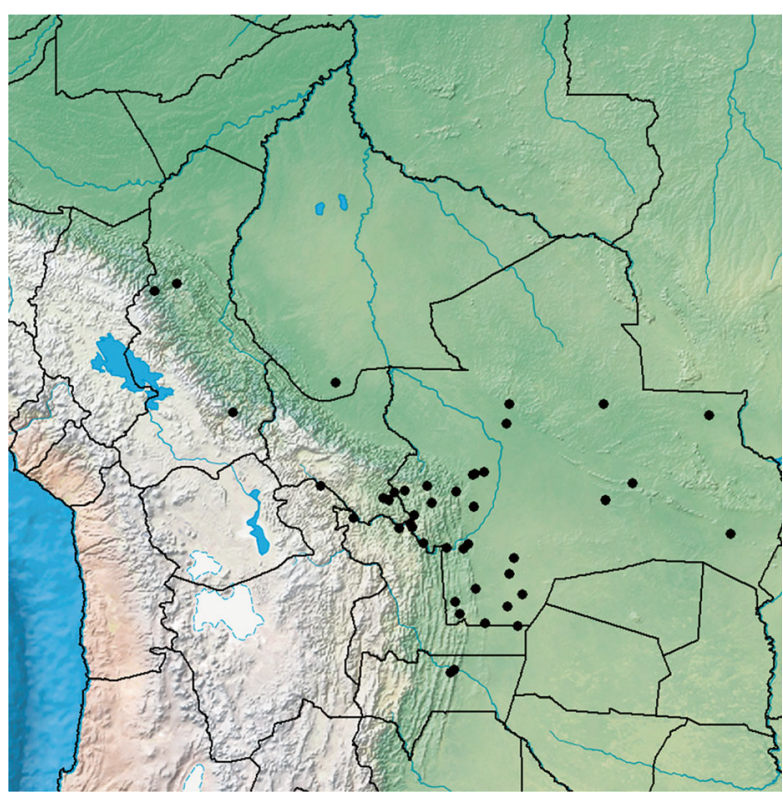

Map 7. Distribution of Ipomoea amnicola (O), essentially a Chaco species which also occurs in the drier inter-Andean valleys.
E. Saravia 630 (MO). La Paz: Prov. Sud Yungas, valle del Río Chungamayu, 1340 m, 1 May, 1995, S. G. Beck 22444 (K, LPB). Prov. Tamayo, ANMI Madidi, Machariapo, $14^{\circ} 29^{\prime} 41^{\prime S}$ 6 68 52'54"W, 1820 m, 3 July 2005, A. Araujo-M. 2869 (LPB). Potosi: Prov. Charcas, by Río Caine Bridge on road from Anzaldo to Torotoro, $17^{\circ} 58^{\prime} 21^{\prime \prime S} 65^{\circ} 55^{\prime} 10^{\prime \prime} \mathrm{W}$, 2058 m, 25 March 2007, J. R. I. Wood et al. 23244 (K, LPB). Santa Cruz: Prov. Germán Busch, Carmen Rivero TórrezCarmen Viejo, $18^{\circ} 49^{\prime} 22^{\prime \prime S} 58^{\circ} 37^{\prime} 14^{\prime \prime} \mathrm{W}, 162 \mathrm{~m}, 14$ May 2008, G. A. Parada 947 (MO, OXF, USZ). Prov. Caballero, $0.5 \mathrm{~km} \mathrm{E}$ of La Palisada on road from Comarapa to Mairana, $18^{\circ} 04^{\prime} \mathrm{S} 64^{\circ} 26^{\prime} \mathrm{W}, 1500 \mathrm{~m}, 9$ March 2005, J. R. I. Wood Eं A. Haigh 21839 (K, LPB). Prov. Chiquitos, $20 \mathrm{~km}$ al Oeste de San José de Chiquitos, $17^{\circ} 46^{\prime} 38^{\prime \prime S} 60^{\circ} 57^{\prime} 25^{\prime \prime} \mathrm{W}, 261 \mathrm{~m}, 7$ April 2009, J. R. I. Wood E P. Pozo 26078 (K, LPB, UB, USZ). Prov. Cordillera, $11 \mathrm{~km}$ N of La Mora on Abapo road, $18^{\circ} 21^{\prime} \mathrm{S} 63^{\circ} 12^{\prime} \mathrm{W}, 550$ m, 19 April 1998, M. Nee 49098 (MO, NY, USZ). Prov. Florida, c. $0.5 \mathrm{~km}$ de Hierba Buena, sobre la carretera a Mairana, lado de un río, $17^{\circ} 58^{\prime} 55^{\prime \prime} \mathrm{S}, 64^{\circ} 01^{\prime} 36^{\prime \prime} \mathrm{W}, 2155 \mathrm{~m}$, 11 April 2003, J. R. I. Wood 19654 (BOLV, K, LPB, USZ). Prov. Ibañez, city of Santa Cruz, $17^{\circ} 46^{\prime} \mathrm{S} 63^{\circ} 11^{\prime} \mathrm{W}, 420 \mathrm{~m}$, 29 May 1998, M. Nee 49480 (LPB, MO, NY, USZ). Prov. Nuflo de Chávez, c. $10 \mathrm{~km}$ N of San Julian on road to San Ramón, 16 51'43"S 62 36'39'W, 244 m, 26 July 2014, J. R. I. Wood E D. Soto 27947 (K, LPB, OXF, USZ). Prov. Ángel Sandoval, $57 \mathrm{~km}$ al S de Las Petas sobre el camino a Candelaria, $16^{\circ} 43^{\prime} 06^{\prime \prime} \mathrm{S} 59^{\circ} 00^{\prime} 12^{\prime \prime} \mathrm{W}, 120 \mathrm{~m}, 12$ May 2008, J. R. I. Wood et al. 24870 (K, LPB, UB, USZ). Prov. Vallegrande, Río Grande, $2 \mathrm{~km}$ de la junta de Nancahuasa, $19^{\circ} 04^{\prime} 43^{\prime \prime S} 63^{\circ} 40^{\prime} 33^{\prime \prime W}, 507$ m, 22 Aug. 2012, G. A. Parada et al. 4866 (USZ). Tarija: Prov. Gran Chaco, $41 \mathrm{~km}$ E of Palos Blancos hacia Villamontes, $21^{\circ} 17^{\prime} 60^{\prime S} \mathrm{~S} 63^{\circ} 36^{\prime} 54^{\prime \prime} \mathrm{W}, 17$ July 2003, M. S. Ferrucci et al. 1752 (CTES, USZ).

CONSERVATION STATUS. Least concern.

PHENOLOGY. Usually flowering at the end of the summer rains and the beginning of the winter dry season from March to July.

NOTES. In the field Ipomoea amnicola is usually easily recognised by the relatively small corolla which is pale pink with a dark pink centre. The leaves are quite glabrous, usually somewhat glaucous and slightly fleshy. It is not a very easy plant to dry successfully so leaves are often deciduous on herbarium specimens.

19. Ipomoea maurandioides Meisn. (Meisner 1869: 275). Type: Brazil, Rio Grande do Sul, Porto Alegre, Sello 3619 (B十, image $\mathrm{F}$ !).

Trailing or twining herb from central tap root, stems glabrous to thinly pubescent. Leaves petiolate, $3-5 \times 1-5$ $\mathrm{cm}$, narrowly ovate-deltoid, acute, sagittate or cordate, the auricles acute to obtuse (rarely rounded), green on both surfaces, glabrous (rarely thinly pubescent); petioles $1-2$ $(-3.5) \mathrm{cm}$. Inflorescence of solitary, axillary, pedunculate 
flowers (rarely in 2 - 3-flowered cymes); peduncles 0.5 4.5; bracteoles minute, c. $1 \mathrm{~mm}$ long, deltoid, caducous; secondary peduncles (if present) $7-17 \mathrm{~mm}$; pedicels 5 - $21 \mathrm{~mm}$; sepals unequal, glabrous, outer 5 - $8 \mathrm{~mm}$, broadly oblong-lanceolate or oblong-ovate, obtuse, greenish-scarious, 3-veined; inner 9-12 mm, oblong-oblanceolate, rounded and often mucronulate, with broad scarious margins. Corolla $4-6 \mathrm{~cm}$, pink, funnel-shaped, glabrous, limb $3.5-4 \mathrm{~cm}$ diam., unlobed. Capsule $12 \times 6 \mathrm{~mm}$, ovoid, glabrous; seeds $6 \times 2.5 \mathrm{~mm}$, blackish, tomentellous. Figs 5A, $6 \mathrm{H}-\mathrm{M}$.

DISTRIBUTION \& HABITAT. Widely distributed in the cerrado biome of Brazil, Paraguay and Bolivia. In Bolivia
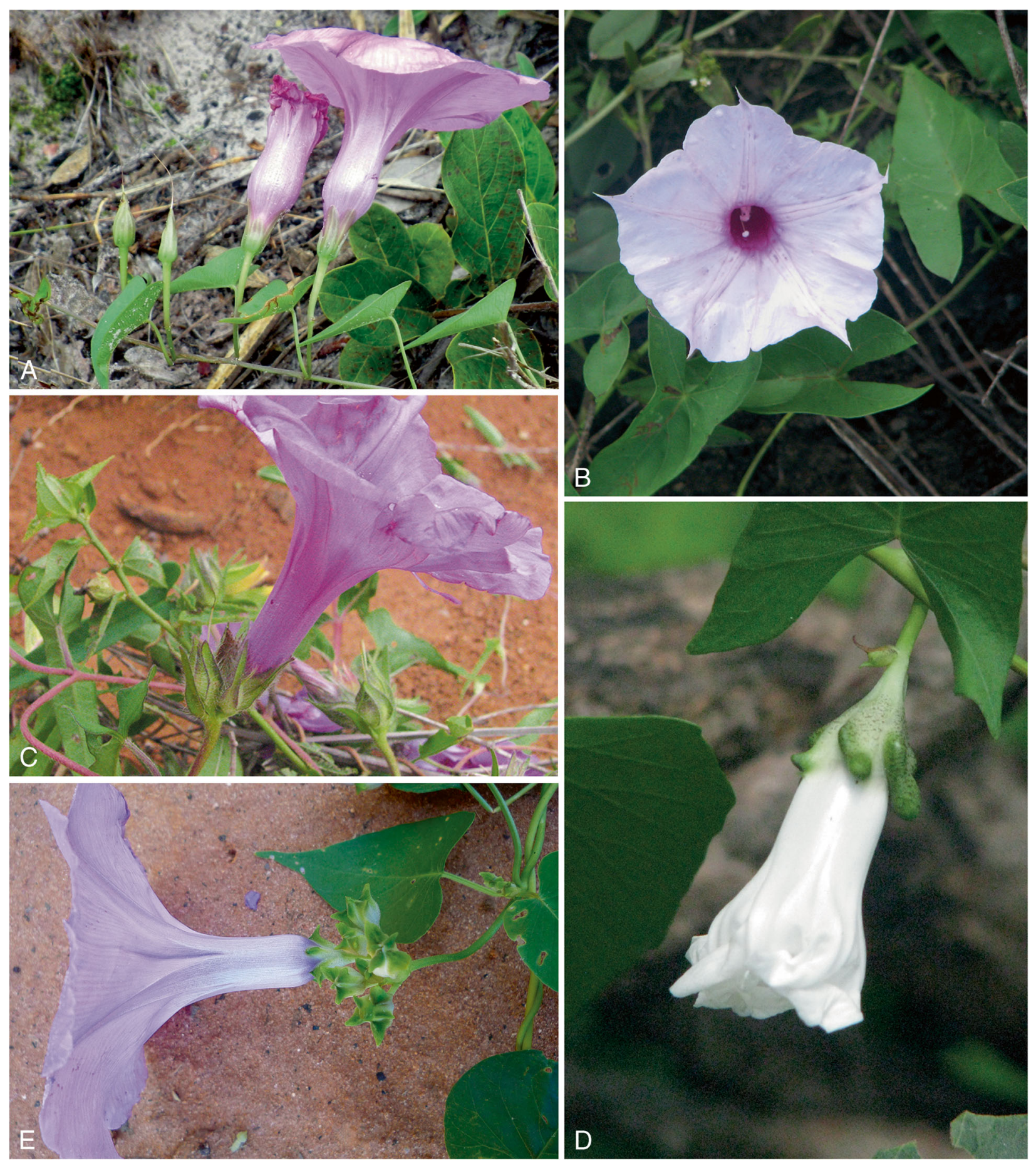

Fig. 5. A Ipomoea maurandioides; B I. mucronatoproducta; C I. hewittacea; D, E I. bahiensis. PHOTOS: A JOHN WOOD; B DARWIN INITIATIVE PROJECT 16-004; C - D DANIEL SOTO; E BETH WILLIAMS. 

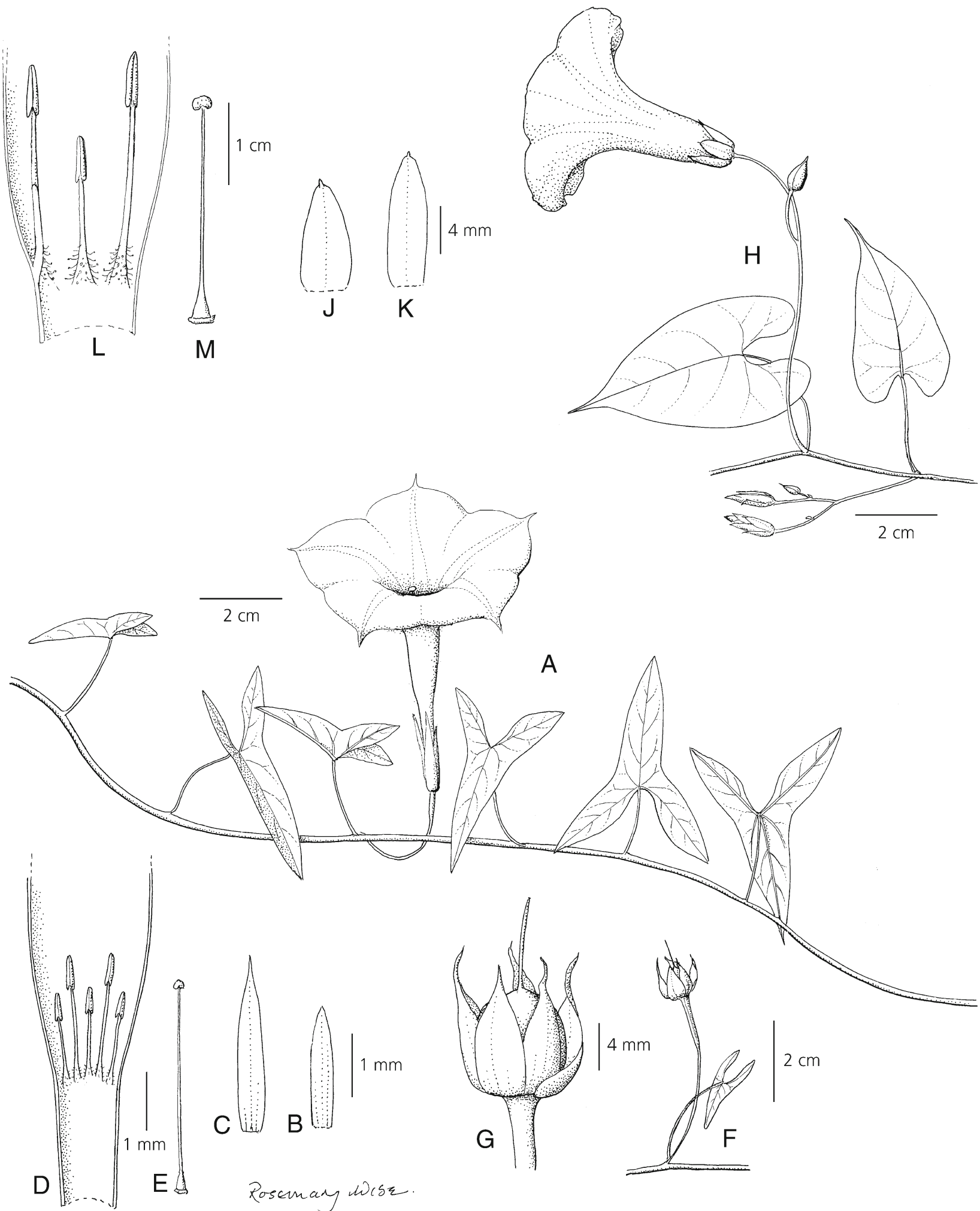

A
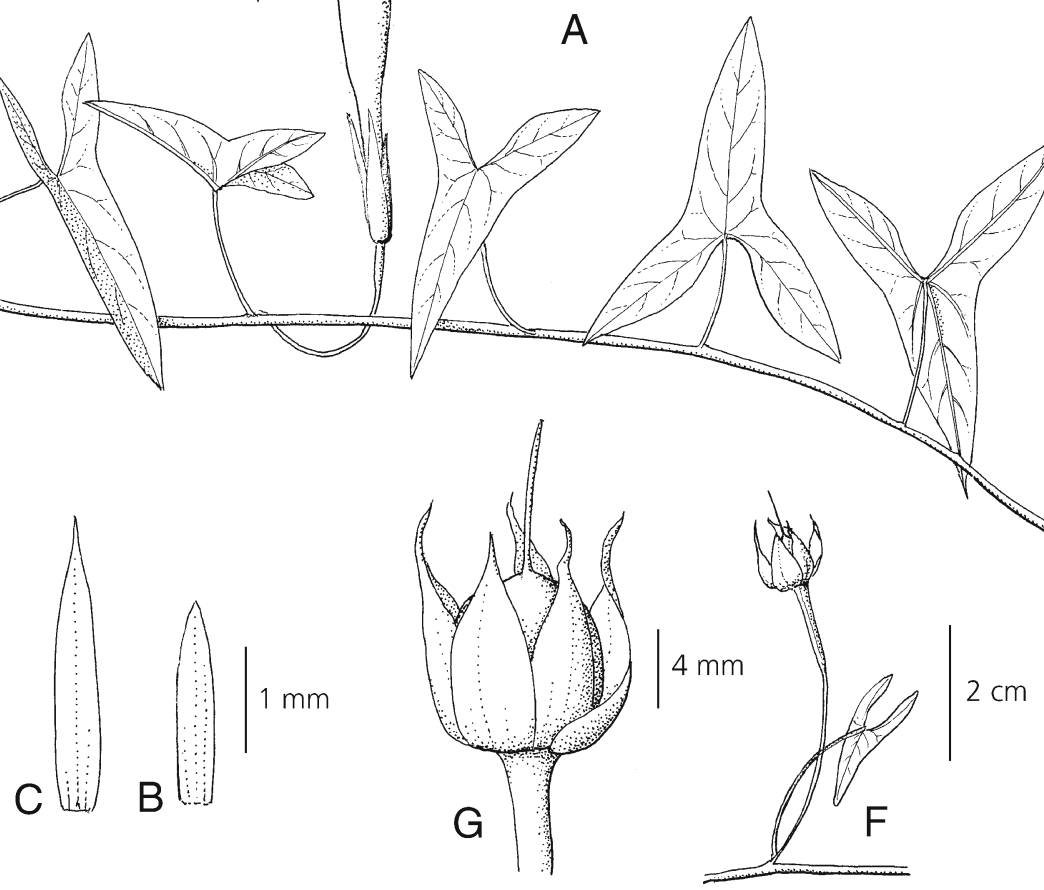

Rosemang wise.

Fig. 6. A - G Ipomoea mucronatoproducta. A habit; B outer sepal; C inner sepal; D corolla opened out to show stamens; E ovary and style; F shoot with young fruiting inflorescence; G calyx with young fruit. H - M I. maurandioides. H habit; J outer sepal; K inner sepal; L section of corolla showing 3 stamens; M ovary and style. A - G from Wood \& Villarroel 25474; H - M from Wood \& Williams 27842. DRAWN BY ROSEMARY WISE. 




Map 8. Distribution of Ipomoea maurandioides (O), a characteristic species of the cerrado biome in Bolivia favouring rock outcrops.

locally abundant in open, dry sandy and rocky cerrado and campo rupestre in the Chiquitania up to $900 \mathrm{~m}$; it is especially characteristic of rock outcrops. Map 8.

SELECTED SPECIMENS OF 30 EXAMINED. BOLIVIA. Santa Cruz: Prov. Germán Busch, km 65 - 70 desde Carmen Rivero Tórrez en camino a Rincón del Tigre, $18^{\circ} 16^{\prime} 25^{\prime \prime} \mathrm{S} 58^{\circ} 14^{\prime} 30^{\prime \prime} \mathrm{W}, 344 \mathrm{~m}, 1$ July 2009, D. Soto $\mathcal{E}^{\circ}$ I. Linneo 1303 (K, LPB, USZ). Prov. Chiquitos, Santiago de Chiquitos, meseta de Motacú, $18^{\circ} 16^{\prime} 36^{\prime \prime} \mathrm{S}$ $59^{\circ} 41^{\prime} 30^{\prime \prime} \mathrm{W}, 900 \mathrm{~m}, 26$ Nov. 2008, J. R. I. Wood E D. Villarroel 25571 (K, LPB, USZ, UB); entre Quimome y El Tinto, entrando la serranía del oeste, $17^{\circ} 35^{\prime} 44^{\prime \prime S}$ $61^{\circ} 26^{\prime} 21^{\prime \prime W}, 289$ m, 5 Oct. 2008, J. R. I. Wood E P. Pozo 25056 (K, LPB, UB, USZ). Prov. Cordillera, $50 \mathrm{~km} \mathrm{~S}$ of Robore, 300 m, 28 Aug 1997, A. Fuentes $\mathcal{E}$ G. Navarro 2086 (LPB, USZ). Prov. Ángel Sandoval, $2 \mathrm{~km}$ de las Petas sobre el camino hacia Candelaria, $16^{\circ} 24^{\prime} 05^{\prime \prime S}$ $59^{\circ} 10^{\prime} 41$ 'W, 185, 11 May 2006, J. R. I. Wood et al. 24826 (K, LPB, UB, USZ). Prov. Velasco, $160 \mathrm{~km}$ de Santa Rosa de la Roca a Piso Firme en la laja al lado del cruce a Florida, $14^{\circ} 36^{\prime} 27^{\prime \prime S} 61^{\circ} 29^{\prime} 31^{\prime \prime W}$, 271 m, 22 April 2004, J. R. I. Wood E H. Huaylla 20780 (HSB, K, LPB, USZ); $10 \mathrm{~km}$ de San Rafael hacia San José de Chiquitos, 16 $52^{\prime} 22^{\prime \prime S}$ $60^{\circ} 39^{\prime} 03 " \mathrm{~W}, 335 \mathrm{~m}, 3$ Dec. 2007, M. Atahuachi et al. 1435 (BOLV, LPB).

\section{CONSERVATION STATUS. Least concern.}

PHENOLOGY. Found in flower in most months of the year but predominantly in the rainy season.

NOTES. Found in many herbaria under the name Ipomoea serpens Meisn. but this is a later homonym of I. serpens L. (1759) and, in any case, the type material represents $I$. paludicola. It is a relatively slender plant, not unlike a robust specimen of Convolvulus arvensis L., often trailing and growing around rocks, and recognised by its habit combined with the very unequal sepals, the inner sepals rounded and much longer than the ribbed outer sepals. The following variety can also be recognised:

Ipomoea maurandioides var. subtomentosa (Chodat $\mathcal{E}$ Hassl.) J. R. I. Wood $\mathcal{E} R$ R. W. Scotland, comb. et stat. nov.

http:/ /www.ipni.org/urn:lsid:ipni.org:names:77148117-1

Basionym: Ipomoea serpens Meisn. var. subtomentosa Chodat \& Hassl., Bull. Herb. Boiss. Ser. 2, 5: 694 (Chodat \& Hassler 1905). Type: Paraguay, E. Hassler 6109 (holotype G, isotype BM000089475!).

Ipomoea subtomentosa (Chodat \& Hassl.) O'Donell (1953: 239).

Differs from var. maurandioides in the minutely pubescent leaves, petioles, stems and peduncles, and (reportedly) in the more rounded capsules. A few Bolivian specimens are \pm pubescent and resemble the type and other collections from Paraguay determined by O'Donell as Ipomoea subtomentosa but they are never as hirsute as some Brazilian examples, such as Harley 21280 (K) or Sano et al. 14538 (K). They do not seem to be anything more than minor variants of $I$. maurandioides.

SPECIMENS eXAMINed. BoliviA. Santa Cruz: Prov. Chiquitos, entre San José and Roboré, $300 \mathrm{~m}$, Feb. 1954, M. Cardenas 4456 (LIL); Valle de la Luna, Serranía de San José, 17 $31^{\circ} 28^{\prime \prime S} 60^{\circ} 27^{\prime} 35^{\prime \prime}$, $505 \mathrm{~m}, 1$ March 2007, J. R. I. Wood et al. 22871 (HSB, K, LPB).

20. Ipomoea incarnata (Vahl) Choisy (1845: 359). Convolvulus incarnatus Vahl (1798: 12). Type: Curaçao, von Rohr (lectotype C10009675, designated here).

Creeping (rarely twining) perennial herb, stems glabrous. Leaves petiolate, $3.5-6 \times 1-2 \mathrm{~cm}$, deltoid, acute and apiculate, base sagittate with wide-spreading, usually acute auricles, both surfaces glabrous, abaxially paler, somewhat reticulate; petioles $1-3 \mathrm{~cm}$. Inflorescence of $1(-2)$ shortly pedunculate flowers; peduncles $0.6-1.7 \mathrm{~cm}$; bracteoles minute, filiform, caducous; pedicels $2.2-4 \mathrm{~cm}$, prominently nerved; sepals subequal, $17-21 \times 4-5 \mathrm{~mm}$, lanceolate, acuminate to a fine aristate point, glabrous, chartaceous, veins prominent, inner sepals with scarious margins; corolla $7-8 \mathrm{~cm}$ long, funnel-shaped, pink, glabrous, limb $6-7 \mathrm{~cm}$ diam. Capsule ovoid, $9-10 \mathrm{~mm}$ long, glabrous; seeds $4-5 \mathrm{~mm}$ long, shortly pubescent. Fig. 3D. 
TYPIFICATION. There are two syntypes at $\mathrm{C}$ which appear to be duplicates of the same collection. The more complete is here designated as lectotype.

DISTRIBUTION \& HABITAT. In Bolivia it is known from only two locations in very dry areas of the interAndean valleys between 600 and $1500 \mathrm{~m}$ where it grows in open xerophytic bushland on rocky ground. This species is an indicator of arid conditions as suggested by its somewhat disjunct distribution in South America being common only in the caatinga region of NE Brazil, coastal Peru, the Galapagos Islands, the Guajira region of Colombia and adjacent parts of coastal Venezuela.

SPECIMENS eXAMINED. BOLIVIA. Cochabamba: Prov. Campero, c. $3 \mathrm{~km}$ E of Peña Colorada, by large sandstone bluff overlooking Río Mizque, $18^{\circ} 09^{\prime} \mathrm{S}, 64^{\circ} 50^{\prime} \mathrm{W}, 1500 \mathrm{~m}$, 5 March 2004, J. R. I. Wood 20382 (BOLV, K, LPB); 6 km de Peña Colorada sobre el camino a Saipina, 1500 m, 30 March 2013, J. R. I. Wood et al. 27708 (K, LPB, USZ). Tarija: Prov. Gran Chaco, $1 \mathrm{~km}$ W of Pilcomayo gorge along road from Villamontes to Palos Blancos, $600 \mathrm{~m}, 20$ Jan. 2001, J. R. I. Wood Eं D. J. Goyder 16883 (K, LPB); 5 $10 \mathrm{~km}$ from Villamontes towards Palos Blancos, 21 13'49"S 633' $34^{\prime \prime} \mathrm{W}, 442 \mathrm{~m}, 24$ March 2013, J. R. I. Wood et al. 27597 (LPB, OXF, USZ).

CONSERVATION STATUS. Within Bolivia this species is unlikely to be found in many more places and so should be classified as Endangered (EN) nationally, although neither location is threatened with habitat change. However this species is common elsewhere in South America and is clearly under no threat at continental level. PHENOLOGY. Flowers after significant summer rain from January to April.

NOTES. Easily recognised by the lanceolate, finely acute, elongate sepals which are very prominently veined. Fig. 3D.

21. Ipomoea mucronatoproducta J. R. I. Wood $\mathcal{E} R$. W. Scotland, sp. nov. Type: Bolivia, Santa Cruz, Prov. Germán Busch, Rincón del Tigre, portón de la entrada a la Misión, sobre el camino hacia Carmen Rivero Tórrez, J. R. I. Wood E D. Villarroel 25474 (holotype USZ; isotypes $\mathrm{K}, \mathrm{LPB}, \mathrm{UB}$ ).

http:/ /www.ipni.org/urn:lsid:ipni.org:names:77148118-1

Glabrous trailing herb, probably perennial, stems to 1.5 $\mathrm{m}$ long. Leaves petiolate, narrowly deltoid, $1.5-3.2 \times$ $0.4-1 \mathrm{~cm}$ (measured above intersection with petiole), apex obtuse and minutely mucronate, base strongly sagittate, the auricles deltoid, lanceolate, acute, basally asymmetric, $1-2.5 \times 0.2-0.6 \mathrm{~cm}$ so leaves sometimes appearing 3-lobed, both surfaces glabrous; petioles $1.1-2.7 \mathrm{~cm}$. Inflorescence of solitary or paired, axillary, pedunculate flowers; peduncles $2.6-4 \mathrm{~cm}$; bracteoles $2-3 \times 1 \mathrm{~mm}$, ovate, acuminate, caducous; secondary peduncles (when present) $10 \mathrm{~mm}$, pedicels
6 - $16 \mathrm{~mm}$, thickened upwards; sepals unequal, oblong-lanceolate, acuminate to a fine aristate point, outer shorter, $11-12 \times 2-2.5 \mathrm{~mm}$, inner $15-16$ $\mathrm{mm}$; corolla $7-8 \mathrm{~cm}$, narrowly funnel-shaped with a long narrow basal tube, glabrous, tube deep pink inside, limb 5-6 cm diam., pale pink, unlobed, the midpetaline bands terminating in a fine point 5 $6 \mathrm{~mm}$ long; stamens included, filaments unequal, glabrous apart from the pubescent basal expanded part, shorter filaments $10 \mathrm{~mm}$, longer $15 \mathrm{~mm}$; anthers linear, $3.5 \times 0.5 \mathrm{~mm}$; style $2.5 \mathrm{~cm}$, glabrous, stigma obscurely bilobed. Capsule (immature) ovoid, $7 \times 6 \mathrm{~mm}$, glabrous; seeds not known. Figs 5B, 6A - G.

RECOGNITION. Ipomoea mucronatoproducta sometimes grows with and is similar in habit and leaf shape to I. maurandioides. In the field it is readily distinguished by the corolla lobes which terminate in a long fine point $5-6 \mathrm{~mm}$ in length. Herbarium specimens are best identified by the finely acuminate sepals, the inner ones reaching $15 \mathrm{~mm}$ in length.

DISTRIBUTION \& HABITAT. In Bolivia only known from a small area of seasonally damp cerrado on compacted soil at Rincón del Tigre where it grows in association with Abildgardia ovata (Burm. f.) Kral, Arachis glabrata Benth., Elionurus muticus (Spreng.) Kuntze, Mimosa xanthocentra Mart., Panicum exiguum Merz, Ruellia hygrophila Mart. and a number of endemic species including Stenandrium villarroelii J. R. I. Wood and an as yet undescribed species of Croton. It appears to be a characteristic species of seasonally flooded campo around the Pantanal with several records from Mato Grosso do Sul.

SPeCimens eXAMined. BoliviA. Santa Cruz, Prov. Germán Busch, Rincón del Tigre, portón de la entrada a la Misión, sobre el camino hacia Carmen Rivero Tórrez, 18²'12"S 58¹1'31"W, 208 m, 21 Nov. 2008, J. R. I. Wood E D. Villarroel 25474 (K, LPB, UB, USZ); ibid., $18^{\circ} 11^{\prime} 56^{\prime \prime} \mathrm{S} 58^{\circ} 11^{\prime} 24^{\prime \prime} \mathrm{W}, 201 \mathrm{~m}, 20$ March 2011, J. R. I. Wood et al. 27242 (K, LPB, USZ); camino del Portón [de La Misión, Rincón del Tigre] a La Gaiba, $18^{\circ} 09^{\prime} 24^{\prime \prime S} 58^{\circ} 09^{\prime} 52^{\prime \prime W}, 181$ m, 11 July 2012 , M. Atahuachi et al. 1887(LPB). BRAZIL. Mato Grosso: $68 \mathrm{~km}$ W of Jardim, 27 June 1977, A. Krapovickas $\mathcal{E}^{2}$ A. Schinini 327519 (FTG). Mato Grosso do Sul: Mun. Corumbá, Porto Esperança, 18 Nov. 1945, B. Lutz s.n. (R); Mun. Corumbá, Invernada, Faz. Acurizal, 19³8'S $57^{\circ} 10^{\prime} \mathrm{W}, 90$ m, 19 Oct. 1987, A. Pott et al. 3642 (CPAP); Mun. Miranda, Est. Caiman, 19 $50^{\prime} 25^{\prime \prime S} 56^{\circ} 22^{\prime} 08^{\prime \prime} \mathrm{W}$, 95 m, 5 April 1998, A. Pott et al. 7944 (CPAP); Mun. Bonito, Lagoa das Pedras, 21 ${ }^{\circ} 15^{\prime} \mathrm{S} 56^{\circ} 33^{\prime} \mathrm{W}, 23$ March 2000, V. J. Pott et al. 4156 (CPAP); Mun. Bela Vista, Rod. BR-267, proximo do trevo para Bela Vista, 16 Nov. 2002, G. Hatschbach et al. 74293 (MBM).

CONSERVATION StATUS. Data deficient (DD). Based on the extent of its known occurrence in Bolivia this species would be classified as critically endangered 
(CR) but given the extent of its occurrence in Mato Grosso do Sul and our inadequate knowledge of the flora of the Pantanal in Bolivia there is every reason to expect that careful search will reveal additional populations.

PHENOLOGY. Found in flower almost throughout the year except in the driest periods.

NOTES. Molecular studies using ITS confirm a close relationship with Ipomoea maurandioides and, more surprisingly with $I$. incarnata. Less surprisingly it shows a close relationship with an undescribed Brazilian species, which has similar sepals but lacks the apiculate corolla lobes. However, these studies confirm the distinctness of all four species. Some of the the Brazilian material of I. mucronatoproducta is tentatively identified as the corollas are not well-preserved. However the Hatschbach and Lutz colections unmistakeably belong to this species.

22. Ipomoea squamisepala O'Donell (1950b: 453). Ipomoea angulata Mart. ex Choisy (1845: 371), non I. angulata Lam. (Lamarck 1793). Type: Brazil, Pohl 1646 (holotype M).

Erect undershrub from a xylopodium to c. $1 \mathrm{~m}$, stems very woody, somewhat ridged, glabrous; plant drying blackish. Leaves shortly petiolate, $(2-) 4-6 \times(0.2-)$ $0.5-1.5(-3) \mathrm{cm}$. linear-oblong, oblong-elliptic or oblanceolate, obtuse to acute and apiculate, cuneate at base, glabrous; petioles $0-5 \mathrm{~mm}$, poorly defined. Inflorescence racemose, terminal, typically elongate to $40 \mathrm{~cm}$, sometimes branched but sometimes much reduced, often dense, formed of shortly pedunculate cymes from the upper leaf axils; peduncles $0-1.5 \mathrm{~cm}$, erect; bracteoles fugacious (not seen); secondary peduncles c. $2 \mathrm{~cm}$, often rhachis-like, pedicels $3-8 \mathrm{~mm}$; sepals very unequal, obovate-elliptic, rigid, glabrous, outer $2-4 \times$ $2 \mathrm{~mm}$ long, obtuse, white-margined, inner $5-7 \times 3-4$ $\mathrm{mm}$, rounded, margins scarious; corolla $2-4 \mathrm{~cm}$, funnelshaped, white or lilac, glabrous, limb c. $2.5-3 \mathrm{~cm}$ diam. Capsule and seeds not seen.

DISTRIBUTION \& HABITAT. A typical cerrado species, common in Brazil but known only from a single location near Santo Corazón in Bolivia.

SPECIMENS EXAMINED. BoliviA. Santa Cruz: Prov. Ángel Sandoval, $30 \mathrm{~km}$ W of Santo Corazón, Serranía Bella Boca, 1757'53"S 5901'33"W, 750 m, 25 April 1997, A. Fuentes et al. 1776 (ARIZ, BOLV, MO, USZ).

CONSERVATION STATUS. Although only known from a single isolated population this plant grows within a protected area (ANMI San Matías) which consists of a vast tract of inaccessible country. From the air many peaks with cerrado vegetation are clearly visible and this species may turn out to be locally frequent. It is certainly common in parts of Brazil. Without further information it can only be classified as Data Deficient (DD) at the present time.

PHENOLOGY. Found in flower in April.

NOTES. An erect subshrub with white or pale lilac flowers, the leaves at least $0.5 \mathrm{~cm}$ wide and the sepals very unequal.

23. Ipomoea pinifolia Meisn. (Meisner 1869: 250). Type: Brazil, Burchell 6700-7 (lectotype BR 0000005837731!, designated here, isolectotype $\mathrm{K}$ !).

Wiry perennial of cerrado, occasionally leafless, rootstock a xylopodium, stems glabrous, woody, often simple and erect to $1.5 \mathrm{~m}$ but sometimes branched and then branches spreading or twining apically. Leaves sessile, very variable in length $2-14 \times 0.1$ $0.3 \mathrm{~cm}$, linear-filiform, acute, glabrous. Inflorescence of 1 (-5)-flowered axillary cymes from the upper leaf axils, sometimes clustered apically but more commonly forming a long narrow raceme-like inflorescence up to $30 \mathrm{~cm}$ long; peduncles $0-8(-21) \mathrm{mm}$, bracteoles caducous, scale-like, secondary peduncles (if present) up to $4 \mathrm{~mm}$; pedicels $7-10(-15) \mathrm{mm}$; sepals coriaceous, concave, very unequal, outermost $2-6 \mathrm{~mm}$, elliptic to suborbicular, obtuse to rounded, often minutely mucronate, inner $7-12 \mathrm{~mm}$, oblong to elliptic, obtuse to rounded, margins broad, scarious; corolla 3 $4.5 \mathrm{~mm}$, glabrous, pink, gradually widened from base, the limb $3-3.5 \mathrm{~cm}$ diam., undulate, the midpetaline bands ending in teeth. Capsule glabrous, seeds reported to be pilose.

TYPIFICATION. Of the two original syntypes, Burchell 6700-7 and Pohl s.n., only the Burchell collection is present in Martius' herbarium in Brussels so we have selected this as lectotype; there is an isolectotype at $\mathrm{K}$. DISTRIBUTION \& HABITAT. A characteristic species of the cerrado, which is common in central Brazil. In Bolivia it is only known between 400 and $800 \mathrm{~m}$ from around Camp. Huanchaca 1 towards the north of the Serranía de Huanchaca and on the mesesta above Los Fierros in the Noel Kempff Park.

SPECIMEnS eXAMINed. BoliviA. Santa Cruz: Prov. Velasco, PNNKM, Pista Noel Kempff (Huanchaca 1), $13^{\circ} 54^{\prime} 22^{\prime \prime S} 60^{\circ} 48^{\prime} 52^{\prime \prime W}, 400$ m, 16 May 1994, B. Mostacedo et al. 1858 (MO, USZ); ibid., near Camp. Huanchaca 1, 135' 19 "S 6048'47"W, 650 m, 18 May 1994, L. Arroyo et al. 700 (MO); ibid., meseta de Caparuch, de regreso por Los Fierros, 14\%33'35"S $60^{\circ} 45^{\prime} 50^{\prime \prime W}, 800 \mathrm{~m}, 10 \mathrm{March} 1997$, S. Jiménez Ẽ E. Gutiérrez 1385 (FTG, MO).

CONSERVATION STATUS. The Bolivian population is an outlying colony from the main populations in Brazil. No information is available about the size of the Bolivian population but it lies within a protected area 
and faces no current, obvious threat. Without further information it can only be classified as Data Deficient (DD).

PHENOLOGY. The only collections were made in May. NOTES. In habit, very unequal sepals and form of inflorescence resembling a linear-leaved form of Ipomoea squamisepala but differing additionally in the larger pink corolla and larger inner sepals.

Species 24 - 27. These four species form a well-resolved clade apparently lacking distinctive morphological characters. The only obvious common characters lie in the relatively short pedicels seen in all species and the tendency to have a subglobose capsule.

24. Ipomoea bahiensis Willd. ex Roem. EF Schultz (Roemer \& Schultes 1819: 769). Type: Brazil, T. Hoffmannsegg s.n. (holotype B-W 03753-010).

Ipomoea salzmannii Choisy (1838: 59). Type: Salzmann Ẽ Blanchet 2683 (isotype M-0184904).

Trailing or climbing perennial herb to $1.5 \mathrm{~cm}$, stems glabrous. Leaves petiolate, $3-8 \times 0.8-5.5 \mathrm{~cm}$, ovatedeltoid, acuminate and mucronate, base cordate with rounded to acute auricles, glabrous or puberulent, abaxially pale green; petioles $0.5-2 \mathrm{~cm}$. Inflorescence of few-flowered, dense, pedunculate axillary cymes; peduncles $0.5-4(-12) \mathrm{cm}$ long, often very short, puberulent or glabrous; bracteoles $1.5-6 \times 0.5-$ $1.5 \mathrm{~mm}$, ovate, acute, scarious except for green midrib, caducous; pedicels $3-7 \mathrm{~mm}$; sepals unequal, somewhat variable in structure, glabrous, fleshy, white or pale green with darker spots and green apex, abaxially often with a prominent toothlike appendage; outer sepals $6-7 \times 3 \mathrm{~mm}$, obovate or elliptic, obtuse, inner $9-10 \times 4 \mathrm{~mm}$, suborbicularobovate, rounded to truncate with prominent angles, margin scarious; corolla $4-5.5 \mathrm{~cm}$, white, lilac or pink, glabrous, funnel-shaped, limb c. $4 \mathrm{~cm}$ diam., unlobed. Capsule subglobose, $7-8 \mathrm{~mm}$, shortly rostrate, glabrous; seeds lanate. Fig. 5D - E.

DISTRIBUTION \& HABITAT. Ipomoea bahiensis is widespread in eastern Bolivia and Brazil, occurring in the cerrado biome, but is more typical of disturbed bushy places than cerrado proper.

SPECIMENS EXAMINED. BoliviA. Santa Cruz: Prov. Ángel Sandoval, Santo Corazón aeropista, 1756'59"S 6449'30"W, 400 m, 3 May 1997, A. Fuentes E C. Cabrera 1903 (USZ). Prov. Chiquitos, 2 km NW of Robore, $18^{\circ} 20^{\prime} \mathrm{S} 59^{\circ} 46^{\prime} \mathrm{W}$, 22 April 1980, A. Krapovockas E A. Schinini 36391 (LIL); $2 \mathrm{~km}$ de Taperas en el camino a San Juan, 1754'03"S 60²1'01"W, 419 m, 5 March 2011, J. R. I. Wood E D. Soto 27138 (K, LPB, USZ); ibid., $17^{\circ} 54^{\prime} 06^{\prime \prime S} 60^{\circ} 21^{\prime} 05^{\prime \prime} \mathrm{W}, 406 \mathrm{~m}, 18$ April
2013, J. R. I. Wood et al. 27877 (LPB, OXF, USZ); cumbre del camino, $3 \mathrm{~km}$ de Santiago de Chiquitos hacia Santo Corazón, 18¹9'12"S 59³4'11"W, $701 \mathrm{~m}$, 31 March 2011, J. R. I.Wood E D. Soto 27327 (K, LPB, USZ) — form with white corolla. Prov. Germán Busch, between Carmen Rivero Tórrez and Santa Ana de Chiquitos, 1840'53"S 5852'08"W, 181 m, 19 April 2013, J. R. I. Wood et al. 27893 (K, LPB, USZ). Prov. Nuflo de Chávez, $2.5 \mathrm{~km} \mathrm{~S}$ de Concepción en el camino a Lomerío, $15^{\circ} 52^{\prime} 38^{\prime \prime S} 61^{\circ} 50^{\prime} 47^{\prime \prime} \mathrm{W}, 500$ m, 29 April 2009, J. R. I. Wood et al. 26205 (K, LPB, UB, USZ). Prov. Velasco, Puente Uruguayito, Concepción-Santa Rosa de la Roca, 1552'30"S 6150'39"W, 350 m, 18 April 2004, J. R. I. Wood Eं H. Huaylla (K, LPB, USZ); $40 \mathrm{~km}$ de Santa Rosa de la Roca en el camino a Piso Firme, $15^{\circ} 36^{\prime} 12^{\prime \prime S} 61^{\circ} 31^{\prime} 03$ "W, 363 m, 13 April 2013, J. R. I. Wood et al. 27797 (LPB, OXF, USZ); between Santa Rosa de la Roca and Carmen Ruiz, 16 $00^{\prime} 52^{\prime \prime S}$ 61 $12^{\prime} 11^{\prime \prime W}, 334 \mathrm{~m}, 14$ April 2013, J. R. I.Wood et al. 27821 (LPB, OXF, USZ); 5 km from San Ignacio on road to San Matías, $16^{\circ} 21^{\prime} 40^{\prime \prime S} 60^{\circ} 55^{\prime} 01^{\prime \prime W}, 426 \mathrm{~m}, 15$ April 2013, J. R. I. Wood Ẽ B. Williams 27841 (K, LPB, USZ).

CONSERVATION STATUS. Least Concern (LC). A weedy species, abundant locally in Brazil, and quite frequent in the Chiquitania region of eastern Bolivia.

PHENOLOGY. In Bolivia flowers at the end of the summer rains from March to May.

NOTES. Ipomoea bahiensis has unique sepals. These are fleshy, very pale, spotted near the base and with prominent green tips, these often with a distinct tooth-like appendage. The exact structure appears to be rather variable and difficult to describe accurately even with the aid of photographs showing details. The compact, shortly pedunculate cymes are also distinctive.

25. Ipomoea squamosa Choisy (1845: 376). Type: Brazil, Para, Martius 76 (holotype P, n.v., isotype M).

Convolvulus mattogrossensis Kuntze (1898: 214). Type: Brazil, Mato Grosso, Villa Maria, O. Kuntze s.n. (isotype NY!).

Ipomoea mattogrossensis (Kuntze) K. Schum. (Schumann 1900: 383).

Twining perennial herb or small liana, stems glabrous to thinly pubescent. Leaves petiolate, ovate, shortly acuminate, cordate with rounded to obtuse auricles, glabrous except on the veins to subtomentose (var. villosa Ooststr.) on both surfaces, abaxially paler, prominently veined; petioles $3-6(-12) \mathrm{cm}$, usually pubescent. Inflorescence of many-flowered pedunculate axillary cymes, the cymes often dense with shortly pedicellate, undeveloped flowers on the lateral branches; peduncles $4-12 \mathrm{~cm}$, straight, usually pubescent; bracteoles $2-3 \mathrm{~mm}$, ovate, caducous; secondary peduncles $4-16 \mathrm{~mm}$; pedicels 
4 - $15 \mathrm{~mm}$, noticeably more slender than peduncles, glabrous; sepals unequal, glabrous, scariousmargined, accrescent in fruit, at anthesis outer 4 $6 \times 3-5 \mathrm{~mm}$, obovate to suborbicular, obtuse, inner $7-10 \times 5-8 \mathrm{~mm}$, obovate to broadly elliptic, rounded, often nearly completely scarious; corolla 5.5 $6.5 \mathrm{~cm}$, funnel-shaped, pink with dark centre, glabrous, limb 4.5 cm diam., undulate. Capsule 10 - 12×10-12 $\mathrm{mm}$, broadly ovoid to subglobose, rostrate, glabrous; seeds woolly with long hairs.

DISTRIBUTION \& HABITAT. Widely distributed in the neotropics but characteristic of moist lowland forest so in Bolivia restricted to moister areas of the Amazon watershed.

SPECIMEnS eXamined. BoliviA. Beni: Prov. Cercado, W side of entrance to Trinidad airport, $14^{\circ} 49^{\prime} 24^{\prime \prime S}$ 64 55'12"W, 157 m, 26 Nov. 2007, M. Atahuachi et al. 1371, (BOLV); Prov. Yacuma/Ballivian, Est. Biologica de Beni, Com. Tierra Santa, 66 $37^{\circ} \mathrm{S}$ 1430'W, 200 m, 14 Sept. 1994, E. Rivero 152 (CTES, LPB, SP, USZ). La Paz: Prov. Iturralde, camino a Ixiamas, Arroyo Huri-Huapo, $14^{\circ} 03$ 'S 6755'W, 365 m, 15 Oct. 1995 L. Vargas et al. 1327 (LPB, MO). Prov. Larecaja, Charopampa, Mapiri, 570 m, Nov. 1907, O. Buchtien 1963 (US); 43 km from Guanai towards Mapiri, $15^{\circ} 26^{\prime} \mathrm{S} 68^{\circ} 04^{\prime} \mathrm{W}, 730$ m, 8 Aug. 2004, S. G. Beck 29480 (K, LPB) [var. villosa]. Prov. Sud Yungas, below Espia, Río Bopi, 950 m, 5 Aug. 1921, C. White 625 (NY). Pando: Prov. Suárez, $4 \mathrm{~km} \mathrm{NW}$ of Cobija hacia abajo Virtude, $11^{\circ} 01^{\prime} 10^{\prime \prime S} 68^{\circ} 48^{\prime} 19^{\prime \prime} \mathrm{W}, 200 \mathrm{~m}, 30$ Aug. 2007, M. Mendoza $\mathcal{E}$ Rivadeneira 2598 p.p. (K, US). Santa Cruz: Prov. Velasco, $5-7 \mathrm{~km} \mathrm{~S}$ of Río Iténez and $15 \mathrm{~km}$ SE of Flor de Oro, senda a antena, $13^{\circ} 36^{\prime} \mathrm{S} 60^{\circ} 54^{\prime} \mathrm{W}, 530 \mathrm{~m}, 17$ Aug. 1992, M. Toledo 87 (NY, USZ); PNNKM, camino entre Los Fierros and Aserradero Moira, 14 33'S 6053'W, 225 m, 1 July 1993, M. Saldias et al. 2907 (ARIZ, BOLV, MO, USZ); PNNKM, Bajo Paraguá, Concesión Moira, $13^{\circ} 40^{\prime} \mathrm{S} 61^{\circ} 20^{\prime} \mathrm{W}, 250$ - $350 \mathrm{~m}, 18$ June 1994, T. J. Killeen Eं J. Wellens 6631 (ARIZ, MO, USZ); PNNKM, Reserva Forestal Bajo Paraguá, $14^{\circ} 00^{\prime} 11^{\prime S} 61^{\circ} 10^{\prime} 11^{\prime \prime W}, 250 \mathrm{~m}$, 28 July 1995, T. J. Killeen et al. 7580 (MO, USZ); PNNKM, Arroyo Las Londras, camino al Aserradero Choré, 14 24'18"S $61^{\circ} 08^{\prime} 40 " \mathrm{~W}, 150 \mathrm{~m}$, 22 July 1996, L. Arroyo Ẽ Peña 1326 (FTG, LPB, MO, USZ).

CONSERVATION STATUS. Least Concern (LC).

PHENOLOGY. Flowers principally during the dry season from June to November.

NOTES. The unequal scarious-margined sepals distinguish this species from all similar species except Ipomoea cryptica with which it has been confused so some records identified as I. squamosa in different herbaria have been deleted from the citations above. The two species are extraordinarily similar although not closely related. In Bolivia, the leaves of I. squamosa are always with a few hairs at least on the veins beneath, the corolla is slightly larger $(5.5-6.5 \mathrm{~cm}$ in length) and the outer sepals are at least half the length of the inner sepals.

26. Ipomoea acanthocarpa (Choisy) Aschers. EF Schweinf. (Ascherson \& Schweinfurth 1867: 277).

Calonyction acanthocarpum Choisy (1845: 346). Type: Sudan, Kordofan, T. Kotschy 269 (isotype K!).

Ipomoea piurensis O'Donell (1953: 382), synon. nov. Type: Peru, O. Haught 142 (holotype US!).

Glabrous twining herb. Leaves petiolate, $2-11 \times 1.5-$ $8 \mathrm{~cm}$, ovate-deltoid, shortly and often abruptly acuminate or acute, cordate, auricles rounded to acute, often with a distinct tooth and sometimes shallowly bilobed, abaxially with prominent venation, petioles $1-8 \mathrm{~cm}$. Inflorescence of few-flowered, somewhat congested, pedunculate cymes; peduncle $1-6 \mathrm{~cm}$, often stout and somewhat swollen upwards, sometimes warty, bracteoles $2-3 \mathrm{~mm}$, scale-like, caducous; pedicels $2-5 \mathrm{~mm}$, sometimes warty; sepals slightly unequal, $5-10 \times 3.5-7 \mathrm{~mm}$, the margins white, outer ovate, acute to mucronate, usually conspicuously warty, inner obtuse and mucronate, smooth, slightly larger; corolla $2-3 \mathrm{~cm}$, funnel-shaped, pink or white, glabrous, limb c. $2.5 \mathrm{~cm}$ diam., the midpetaline bands terminating in mucros. Capsule $9-10 \mathrm{~mm}$, subglobose, with prominent persistent style, glabrous; seeds $5.5 \mathrm{~mm}$ long, grey, long-pilose.

DISTRIBUTION \& HABITAT. In Africa this species is widely distributed across the Sahel region from Senegal and Sierra Leone east to Sudan and Ethiopia. In South America it extends in a belt from Peru and Ecuador eastwards to Guyana and northeastern Brazil where it is especially common. In Bolivia it is known from a single collection with no exact details of its habitat.

SPECIMens Seen. BOliviA. Pando: Prov. Manuripi, Conquista, 27 March 1956, E. de la Sota 977 (LIL).

CONSERVATION STATUS. Data Deficient (DD). This is only known in Bolivia from a single old record from a poorly studied part of the country.

PHENOLOGY. Collected in flower in March.

NOTE. We have formally united Ipomoea piurensis with the African I. acanthocarpa as this is the older name. The two are not separable morphologically and we have found no molecular evidence to retain them as separate species. I. acanthocarpa appears to be of American origin and has colonised Africa by longdistance dispersal. The name "acanthocarpa" presumably refers to the spine-like rostrate apex of the capsule.

This species is sometimes confused with Ipomoea dumetorum because of the lateral tooth which is often 
present near the base of the leaf and because of the white-margined sepals which are characteristic of both species. However, I. acanthocarpa is a lowland species, its sepals lack the dark spots of I. dumetorum and the inflorescence is rather compact with very short pedicels. The seeds are long pilose, not minutely tomentellous.

27. Ipomoea hewittacea (Kuntze) J. R. I. Wood E R.W. Scotland, comb. nov.

http://www.ipni.org/urn:Isid:ipni.org:names:77148119-1

Basionym: Convolvulus hewittaceus Kuntze, Revisio Generum plantarum Vol. 3: 213 (1898). Type: Brazil, Mato Grosso, O. Kuntze s.n. (holotype B†, isotype NY!).

Jacquemontia hewittacea (Kuntze) K. Schum. (Schumann 1900: 383).

Ipomoea piresii O’Donell (1952: 229), synon. nov. Type: Brazil, Maranhão, Pires $\mathcal{E}$ Black 1989 (holotype LIL!, isotypes P!, US!).

Perennial twining herb to $2 \mathrm{~m}$, stem scabrous, pubescent, the hairs swollen at base. Leaves shortly petiolate, $2-6 \times 1.5-4 \mathrm{~cm}$, lanceolate to narrowly ovate, slightly constricted above base, acute, base sagittate with narrow sinus and ovate, sometimes shallowly bifurcate, acute auricles, both surfaces thinly pubescent but pubescence denser on veins and margins, abaxially paler; petioles $1-3 \mathrm{~cm}$, pubescent. Inflorescence of pedunculate clusters of 3-4 flowers; peduncles 3-4.5 $\mathrm{cm}$, pubescent; bracteoles $15-21 \times 2-4 \mathrm{~mm}$, lanceolate, acute or subacute, persistent; secondary peduncles and pedicels absent or very short so bracteoles \pm appressed to the calyx; sepals unequal, acuminate, densely pilose and ciliate, outer $13-14 \times 4-$ $5 \mathrm{~mm}$, ovate, inner $10-11 \times 2-3 \mathrm{~mm}$, lanceolate; corolla $4-7 \mathrm{~cm}$ long, funnel-shaped, pink, pilose on midpetaline bands, limb $4-6 \mathrm{~cm}$ diam., undulate. Capsule globose, $7-8 \times 7-8 \mathrm{~mm}$, glabrous; seeds $4.5 \times 3$ $\mathrm{mm}$, obovoid, minutely scabrous. Fig. 5C.

DISTRIBUTION \& HABITAT. An uncommon species of swampy grassland in Bolivia and Brazil, more frequently collected in Bolivia than in Brazil. In Bolivia found in scattered locations below $400 \mathrm{~m}$ in Velasco and Ángel Sandoval provinces

SPECIMENS EXAMINED. BoliviA. Santa Cruz: Prov. Ángel Sandoval, $2 \mathrm{~km}$ de Las Petas sobre el camino hacia Candelaria, $16^{\circ} 24^{\prime} 05^{\prime \prime S} 59^{\circ} 10^{\prime} 41^{\prime \prime} \mathrm{W}, 185 \mathrm{~m}, 11$ May 2008, J. R. I. Wood et al. 24825 (K, LPB, UB, USZ). Prov. Velasco, El Refugio, $14^{\circ} 41^{\prime} \mathrm{S} 60^{\circ} 56^{\prime} \mathrm{W}, 250$ m, 12 Oct. 1994, T. Killeen E् R. Guillén 6699 (MO); ibid., 1444'36"S 61 01'12" W, 150 m, 23 Jan. 1995, R. Guillén Eं V. Roca 2993 (MO); ibid., lado occidental del Río Paragua, 1446'18"S 6102'19"W, 176 m, 21
April 2004, J. R. I. Wood Ẽ H. Huaylla 20756 (HSB, K, LPB, USZ); camino entre El Refugio y El Toledo, $14^{\circ} 46^{\prime} 35^{\prime \prime S} 61^{\circ} 02^{\prime} 50^{\prime \prime} \mathrm{W}, 166 \mathrm{~m}, 8$ Nov. 2009, J. R. $I$. Wood et al. 26374 (K, LPB, UB, USZ); $20-30 \mathrm{~km} \mathrm{~N}$ of Santa Rosa de la Roca hacia Piso Firme, $15^{\circ} 44^{\prime} 32^{\prime \prime S}$ 61 30'53"W, $371 \mathrm{~m}, 13$ April 2013, J. R. I. Wood et al. 27809 (K, LPB, USZ); $15 \mathrm{~km} \mathrm{~N}$ of Santa Rosa de la Roca hacia Piso Firme, $15^{\circ} 46^{\prime} 05^{\prime \prime S} 61^{\circ} 29^{\prime} 24^{\prime \prime} \mathrm{W}, 344$ m, 13 April 2013, J. R. I. Wood et al. 27814 (K, LPB, OXF, USZ); $4 \mathrm{~km} \mathrm{~W}$ of Santa Rosa de la Roca en el camino hacia Concepción, 155ㄴ'S 61 ${ }^{\circ} 29^{\prime} 50^{\prime \prime} \mathrm{W}, 367 \mathrm{~m}, 21 \mathrm{Jan}$. 2014, J. R. I. Wood E D. Soto 27918 (LPB, OXF, USZ).

CONSERVATION STATUS. Using Geocat this species should be provisionally categorised as Vulnerable (VUL) in Bolivia based on an extent of occurrence of about $19,570 \mathrm{~km}^{2}$. None of the observed populations are large although none face any specific threat and there could be many additional populations in poorly known areas of eastern Bolivia. However this species appears to be uncommon also in Brazil so this categorisation may well prove to be correct.

PHENOLOGY. Flowers throughout most of the year except in the driest periods.

NOTES. A very distinctive species because of the subcapitate inflorescence with persistent lanceolate bracteoles, densely pilose sepals, sagittate leaves and globose capsule.

Species 28 - 48. These 21 species are part of a wellresolved clade centred on the Chaco and extending to Argentina, Brazil and Bolivia as well as Paraguay. It constitutes the largest radiation in South American Ipomoea and probably consists of $>50$ species in total. The species share a hirsute corolla and soft, (non-coriaceous), usually hairy sepals. The fruit of many species is unknown but it seems the seeds are very variable, some having long hairs on the margins whereas others are minutely tomentellous or even glabrous. It is unsurprising that this clade is particularly rich in endemic and new species while at the same time presenting problems of species delimitation.

28. Ipomoea hirsutissima Gardner (1842a: t. 471). Type: Brazil, Gardner 3355 (holotype K!, isotype P!).

Ipomoea chrysotricha Meisn. var. boliviana Meisn. (Meisner 1869: 243). Type: Bolivia, Santiago de Chiquitos, A. D’Orbigny 928 (P03878901!, lectotype designated here).

Erect herb to about $40 \mathrm{~cm}$ with a large woody tuberous root, the whole plant densely pilose with rather stiff white hairs swollen at the base. Leaves subsessile, $3-8 \times 1-3.5 \mathrm{~cm}$, oblong - obcuneate, 
obtuse, base cuneate, both surfaces pilose, green; petioles $0-2 \mathrm{~mm}$. Inflorescence of solitary (rarely paired), pedunculate axillary flowers arising from the upper leaf axils; peduncles $1-4 \mathrm{~cm}$; bracteoles $10-25 \times 1-1.5 \mathrm{~mm}$, linear-lanceolate, finely acuminate, caducous; pedicels $3-6 \mathrm{~mm}$; sepals slightly unequal, narrowly ovate, acuminate, pilose, $13-16 \times 4 \mathrm{~mm}$, inner sepals similar but with broad, glabrous margins; corolla $6-7 \mathrm{~cm}$ long, funnelshaped, gradually widened from base, pink, pilose, the hairs with dark bases, limb c. 5 cm diam., shallowly lobed. Capsule $12 \times 5 \mathrm{~mm}$, narrowly ovoid, glabrous; seeds $7 \times 2-3 \mathrm{~mm}$, dark brown, glabrous except for shortly pilose angles. Fig. $7 \mathrm{~B}$.

DISTRIBUTION \& HABITAT. A typical plant of the cerrados of Brazil, Paraguay and Bolivia but nowhere very frequent. In Bolivia it is known from three locations in the south of the Chiquitania but is only common around Santiago de Chiquitos. It appears to have subtly different ecological requirements from other cerrado species such as Ipomoea haenkeana or those of the Noel Kempff Park such as I. procurrens.

SPeCimens examined. Bolivia. Santa Cruz. Prov. Chiquitos, Santiago de Chiquitos, D'Orbigny s.n. (P); ibid., 1928, Bourke-Borrows s.n. (K); ibid., near airstrip, $18^{\circ} 20^{\prime} \mathrm{S} 59^{\circ} 35^{\prime} \mathrm{W}, 600 \mathrm{~m}, 1$ Nov. 1991, A. Gentry Eं $P$. F. Foster 75469 (MO); ibid., 2 - $3 \mathrm{~km} \mathrm{~S}$ of Santiago on road to Roboré, 600 m, 24 Oct. 2001, J. R. I. Wood Ẽ E. Guzmán 17405 (K, LPB, USZ); ibid; at edge of village along trail to El Arco, 18 20'39"S 59 35 31"W, $640 \mathrm{~m}$, 14 Nov. 2002, J. R. I. Wood E M. Mendoza 18515 (K, LPB, USZ); ibid., at edge of village on road to Roboré, $18^{\circ} 20^{\prime} 45^{\prime \prime S} 59^{\circ} 36^{\prime} 25^{\prime \prime} \mathrm{W}, 607$ m, 9 Oct. 2007, J. R. I. Wood Ẽ D. Soto 23437 (K, LPB, UB, USZ); ibid., camino al Arco, 18²0'28"S 59³4'35"W, 708 m, 9 Sept. 2009, D. Soto Ẽ I. Linneo 1276 (USZ). Prov. Germán Busch, Cerro Mutún, 19¹1'04"S 5752'07"W, 730 m, 17 - 20 Oct. 1994, I. G. Vargas et al. 3240 (NY); ibid., $19^{\circ} 12^{\prime} 56^{\prime \prime S} 57^{\circ} 51^{\prime} 61^{\prime \prime} \mathrm{W}, 500$ - 700 m, I. G. Vargas et al. 3287 (NY); Entrando $1-2 \mathrm{~km}$ hacia Santa Rosa de Bocaina en km 70 del camino entre Carmen Rivero Tórrez y Rincón del Tigre, 18²7'56"S 58¹7'03"W, 208 m, 21 Nov. 2008, J. R. I. Wood E D. Villarroel 25482 (USZ).

CONSERVATION STATUS. Using Geocat this species would be classified as Vulnerable (VU) based on its extent of occurrence. However, this is almost certainly an underestimate of the threat. The species is known from three places. Near Santa Rosa de Bocaina only one plant was found; there are no recent records from Cerro Mutún despite several visits during the Darwin Initiative Project 16-004 and it may have become extinct here as a consequence of extensive mining activities; at Santiago de Chiquitos it is still relatively frequent in the cerrados on the plains below the mesetas but these are being rapidly destroyed for housing developments and for "improved" pasture and, unlike Ipomoea psammophila, this species is rare on the mesetas in this area. It should therefore be classified as Endangered (EN) in Bolivia and might even be critically so in the not distant future. Fortunately it also occurs in Brazil and Paraguay but may face similar threats there.

PHENOLOGY. Flowering is stimulated by burning and this species comes into flower as early as September and continues until about January. This is a typical pattern of many cerrado species at Santiago.

NOTES. A very distinct species because of its erect habit, subsessile leaves and stiff spreading hairs which cover almost all parts of the plant including the corolla.

29. Ipomoea cerradoensis J. R. I. Wood E $R$. W. Scotland, sp. nov. Type: Bolivia, Santa Cruz, Prov. Velasco, Parque Nacional Noel Kempff Mercado, la meseta, camino al Camp. Huanchaca 2, J. R. I. Wood, D. Villarroel $\mathcal{E}^{2}$ M. Mendoza 27017 (holotype K, isotypes USZ, LPB).

http:/ /www.ipni.org/urn:lsid:ipni.org:names:77148120-1

Erect or ascending herb to $50 \mathrm{~cm}$, rootstock a woody xylopodium, stem adpressed pubescent. Leaves shortly petiolate, $3-6 \times 1-3.5 \mathrm{~cm}$, ovate to elliptic, base broadly cuneate to rounded, apex obtuse to rounded, minutely mucronate, margin entire, both surfaces densely pubescent with slightly asperous hairs, abaxially paler with prominent dull red veins; petiole $2-5 \mathrm{~mm}$, pubescent. Inflorescence of shortly pedunculate axillary cymes, commonly reduced to $1-2$ flowers; peduncles $1-15 \mathrm{~mm}$, pubescent; bracteoles $2-3 \times 1 \mathrm{~mm}$, oblong-lanceolate, caducous; pedicels $2-4 \mathrm{~mm}$, pubescent; sepals subequal, outer $6-7 \times 4-5 \mathrm{~mm}$, ovate, acute to obtuse, mucronulate, pubescent, inner $6 \times 4-5 \mathrm{~mm}$, ovatesuborbicular, obtuse, mucronulate, pubescent, margin narrow, scarious; corolla pubescent in bud, somewhat glabrescent, white (rarely very pale pink), 5 $6 \mathrm{~cm}$ long, funnel-shaped, limb c. $3 \mathrm{~cm}$ wide, indistinctly lobed; stamens included, filaments unequal, glabrous apart from the pubescent basal expanded part, shorter filaments $8-9 \mathrm{~mm}$, longer $12-14 \mathrm{~mm}$; anthers linear, $3.5 \times 0.5 \mathrm{~mm}$; style 2.3 $\mathrm{cm}$, glabrous, stigma obscurely bilobed, ovary glabrous. Capsule and seeds not seen. Figs 7C, 8 .

RECOGNITION. A relatively distinct cerrado species belonging to the Chaco radiation with the characteristically shortly petiolate leaves of an erect or ascending species. It is similar to Ipomoea hirsutissima and I. aurifera Dammer in habit but is distinguished by the pubescent indumentum, ovate leaves and sepals and shortly pedicellate white flowers borne in small axillary cymes. 

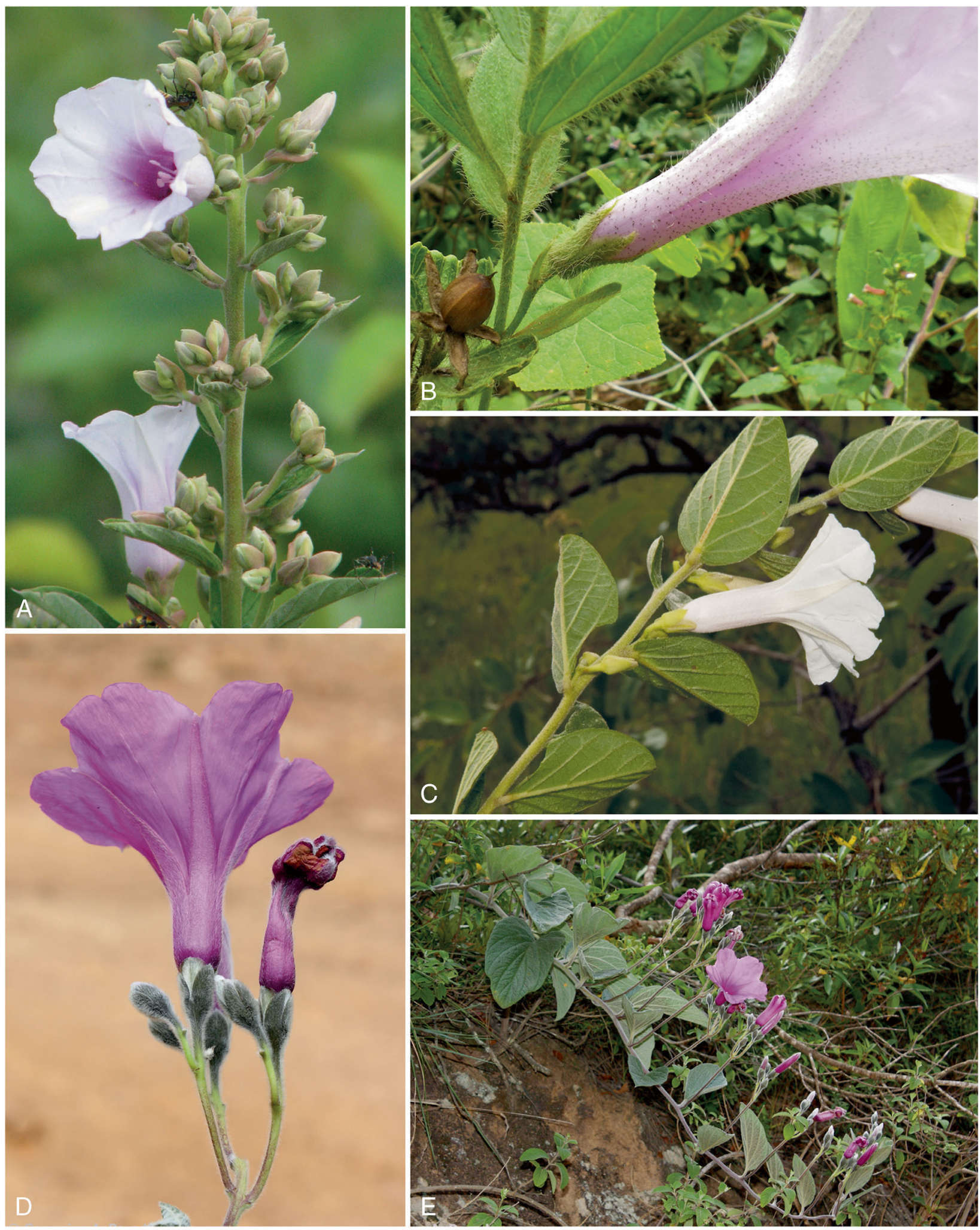

Fig. 7. A Ipomoea haenkeana; B I. hirsutissima; C I. cerradoensis; D - E I. mendozae. PHOTOS: A, C DARWIN INITIATIVE PROJECT 16-004; B JOHN WOOD, D - E ALEXANDER PARADA. 


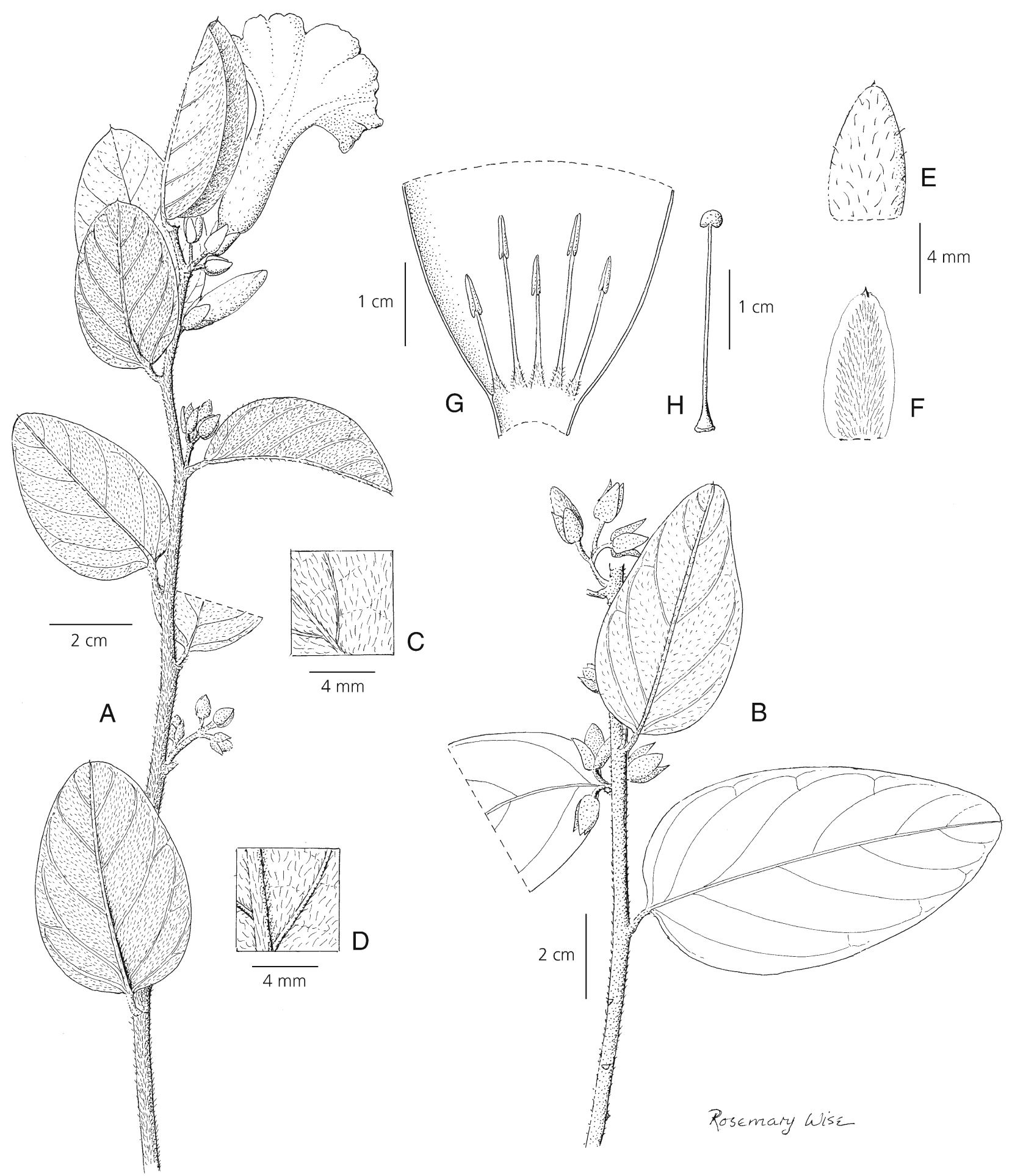

Fig. 8. Ipomoea cerradoensis. A habit; B habit; C adaxial leaf surface; D abaxial leaf surface; E outer sepal; F inner sepal; G corolla opened out to show stamens; H ovary and style. A, C - H from Wood et al. 27017; B from Irwin \& Soderstrom 7399. DRAWN BY ROSEMARY WISE.

DISTRIBUTION \& HABITAT. Open cerrado (campo sujo) with scattered shrubs, often near rock outcrops on the serranias and chapadas of the Precambrian shield of Bolivia and Brazil between 700 and 1000 m. In Bolivia apparently uncommon on the meseta in the PN Noel Kempff Mercado.

SPECIMEnS eXAmined. BoliviA. Santa Cruz: Velasco, PNNKM, la meseta, cerca del Camp. Huanchaca 2, 
14³1'28"S 6044'19"W 710 m, 5 Nov. 2008, J. R. I. Wood et al. 25258 (USZ); ibid.; camino a Camp. Huanchaca 2, 14 $31^{\prime} 55^{\prime \prime S} 60^{\circ} 44^{\prime} 24^{\prime \prime W}, 750$ m, 3 Dec. 2010, J. R. I. Wood et al. 27017 (K, LPB, UB, USZ); PNNKM, Camp. Las Gamas, 1449'24"S 60²3'10"W, 920 m, 6 Nov. 1993, R. Guillén E $T$. Centurión 859 (MO, USZ). BRAZIL. Goías: Serra do Caiapó, $50 \mathrm{~km}$ S of Caiaponia on road to Jataí, 17²12'S $51^{\circ} 47^{\prime} \mathrm{W}, 800$ - 1000 m, 26 Oct. 1964, H. S. Irwin $\mathcal{F}^{2}$ T. R. Soderstrom 7399 (NY); Chapada de Veadeiros, $41 \mathrm{~km} \mathrm{~N}$ of Veadeiros, 1000 m, 17 March 1969, H. S. Irwin et al. 24544 (NY); Goiania, estrada velha para Guapo, 16 Dec. 1975, A. Luna Peixoto et al. 746 (RB); Cavalcante, left margin of Rio São Félix, 1331'45"S 4803'13"W, 29 Nov. 2001, G. Pereira-Silva et al. 5772 (CEN). Minas Gerais: Selviria, Fazenda de Ensino e Pesquisa de UNESP - "Campus" de Ilha Solteira, 1 Nov. 1991, O. Tiritan E M. Paiva 436 (RB). Rondonia: $4 \mathrm{~km}$ de Vilhena, $12^{\circ} 45^{\prime} \mathrm{S}, 60^{\circ} 10^{\prime} \mathrm{W}, 30$ Oct. 1979, M. G. Veira et al. 783 (US).

CONSERVATION STATUS. The Bolivian populations are outlying colonies of a widely distributed species in the Brazilian cerrado biome. No information is available about the size of either Bolivian population but they lie in different parts of the Noel Kempff Mercado National Park within a protected area and face no current, obvious threat. Without further information this species can only be classified as Data Deficient (DD) both in Bolivia and Brazil. PHENOLOGY. Flowers principally at the onset of rain from October to early December.

NOTE. The Rondonia collection, Veira et al. 783, is somewhat anomalous having slightly larger sepals and pink flowers (according to the collection label). In habit and other details it fits Ipomoea cerradoensis and is probably correctly placed here unless further collections from Rondonia prove otherwise.

30. Ipomoea haenkeana Choisy (1845: 358). Type: Bolivia, "Cochabamba", T. Haenke (holotype BR006973261 ex Herb. Mart).

Erect perennial to $2 \mathrm{~m}$, branched towards the apex, stems woody, tomentellous. Leaves subsessile, mostly $3-6 \times 2-4 \mathrm{~cm}$, oblong-obovate, apex rounded and apiculate, base rounded to truncate, slightly asymmetric, adaxially dark green and thinly pilose to subglabrous, abaxially grey-tomentose, petioles $0-4$ $\mathrm{mm}$. Inflorescence of shortly pedunculate cymes from the uppermost leaf axils forming a terminal panicle of raceme-like branches; peduncles $1-3 \mathrm{~cm}$; bracteoles $9-12 \times 1-2 \mathrm{~mm}$, lanceolate, acute, 土persistent; pedicels $2-5 \mathrm{~mm}$ (so cymes very dense); sepals subequal, $7-9 \times 3-4 \mathrm{~mm}$, oblong-ovate, acuminate to shortly apiculate, grey-sericeous; corolla $3.5-4 \mathrm{~cm}$, funnel-shaped, pale pink with a darker centre, pubescent outside, the limb $2.5-3.5 \mathrm{~cm}$ in diam. Capsule and seeds not known. Fig. 7A.
DISTRIBUTION \& HABITAT. Apparently restricted to Santa Cruz Department in Bolivia and adjacent areas of Brazil but extending through Mato Grosso to Minas Gerais. In Bolivia it is a locally common plant of cerrados on lowland plain below $700 \mathrm{~m}$ in the Chiquitania and on the cerrado-like formations west of the Río Piraí but is unexpectedly absent from the mesetas in the Chiquitania. The cited type locality of "Cochabamba" must be an error as Ipomoea haenkeana can never have grown there, the error presumably arising from the fact that Haenke was resident in the Cochabamba area. Map 9.

SELECTED SPECIMENS OF 24 EXAMINED. BOLIVIA. Santa Cruz: Prov. Chiquitos, c. $2-3 \mathrm{~km} \mathrm{~N}$ of Santiago de Chiquitos, W of the road to Santo Corazón, 550 m, 30 March 2002, J. R. I. Wood 17972 (K, LPB, USZ). Prov. Florida, Laguna Volcanes, $2 \mathrm{~km} \mathrm{NW}$ of Bermejo, $18^{\circ} 07^{\prime} \mathrm{S} 63^{\circ} 37^{\prime} \mathrm{W}, 1000$ m, 3 - 4 April 1994, A. Fuentes 348 (LPB, NY, USZ). Prov. Guarayos, $3 \mathrm{~km} \mathrm{~W}$ of Ascension de Guarayos, $15^{\circ} 43^{\prime} \mathrm{S} 63^{\circ} 06^{\prime} \mathrm{W}, 250 \mathrm{~m}, 27$ April 1977, A. Krapovickas $\mathcal{E}^{\circ}$ A. Schinini 31838 (CTES, FTG). Prov. Ichilo, Buenavista, 400 m, 15 April 1921, J. Steinbach 5583 (F, GH, LPB, NY). Prov. Ibañez, Laguna Capibara, $17^{\circ} 47^{\prime} 57^{\prime \prime S} 63^{\circ} 16^{\prime} 25^{\prime \prime} \mathrm{W}, 430$ m, 16 Feb. 1997, A. Fuentes 1743 (LPB, USZ). Prov. Nuflo de Chávez, Rancho Puesto Nuevo, $40 \mathrm{~km} \mathrm{~S}$ of Concepción, $16^{\circ} 25^{\prime} \mathrm{S}, 62^{\circ} 00^{\prime} \mathrm{W}, 700 \mathrm{~m}, 1 \mathrm{March} 1987$, T. J. Killeen 2345 (F, LPB, MO, NY, USZ). Prov. Sara, $9 \mathrm{~km}$ NW of Río Piraí Bridge at La Bélgica, 17³1'06 $63^{\circ} 16^{\prime} 03,370 \mathrm{~m}, 21$ April 2003, M. Nee $\mathcal{E} \sigma^{2}$ M. Sundue 52213 (LPB, NY, USZ). Prov. Ángel Sandoval, San Matias, $16^{\circ} 21^{\prime} \mathrm{S} 58^{\circ} 26^{\prime} \mathrm{W}, 170 \mathrm{~m}, 17$ April 1980,

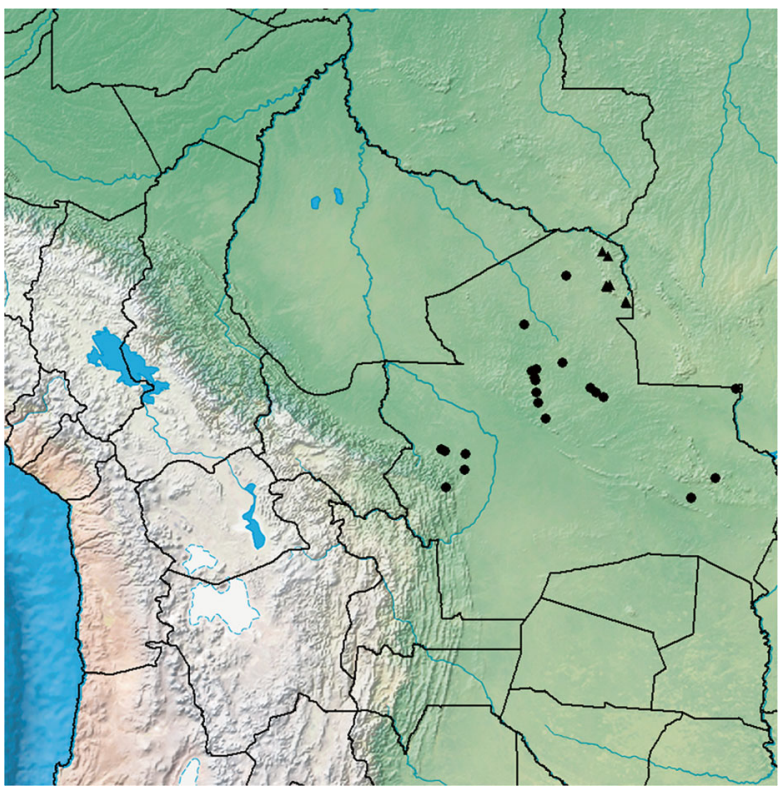

Map 9. Contrasting distributions of two cerrado species: Ipomoea procurrens ( $\mathbf{\Delta}$ ) which is, like many others, restricted to the PN Noel Kempff Mercado and I. haenkeana widespread on the more accessible low-lying cerrados. 
A. Krapovickas $\mathcal{E}$ A. Schinini 36185 (G, LIL); Santo Corazón, aeropista, 460 m, 3 May 1997, A. Fuentes $\mathcal{E}{ }^{2}$ C. Cabrera 1872 (USZ). Prov. Velasco, Reserva Forestal Bajo Paraguá, 1552'S 61 ²8'W, 350 m, 21 March 1994, R. Guillén et al. 1065 (ARIZ, BOLV, USZ); aprox. $5 \mathrm{~km}$ al este del Recreo hacia San Ignacio, $16^{\circ} 20^{\prime} \mathrm{S} 61^{\circ} 02^{\prime} \mathrm{W}$, 426 m, 9 May 2008, J. R. I. Wood et al. 24788 (K, LPB, UB, USZ).

CONSERVATION STATUS. Widely distributed in Santa Cruz Department this species should be classified provisionally as Least Concern (LC). However, the cerrados are being destroyed both in Bolivia and Brazil and the cerrados on lowland plain favoured by Ipomoea haenkeana are particularly vulnerable as they are easily altered by the sowing of imported grasses and the addition of fertilisers. The status of I. haenkeana, therefore, needs to be reviewed regularly and may merit revision to Vulnerable (VUL) in the not too distant future.

PHENOLOGY. Flowers towards the end of the rainy season from February to May.

NOTES. Almost unmistakeable because of its erect shrubby habit, grey, tomentose indumentum and distinct oblong-oblanceolate leaves. It is most likely to be confused with Ipomoea cuneifolia which has narrower leaves and a much shorter, more compact, unbranched terminal inflorescence.

31. Ipomoea virgata Meisn. (Meisner 1869: 241). Type: Brazil, Minas Gerais, Regnell III 192 (lectotype BR 0000005305797!, designated here, isolectotype, K000612808!)

Ascending or erect undershrub from a woody xylopodium, stems woody, somewhat lanate. Leaves sessile, $3-7 \times 2.5-5 \mathrm{~cm}$, broadly ovate to narrowly elliptic, obtuse and apiculate, broadly cuneate at base, adaxially pubescent, abaxially whitish-floccose. Inflorescence of lax axillary cymes, forming an elongate terminal raceme, often somewhat compound below with branches to $7 \mathrm{~cm}$ in length; peduncles $1-4.5 \mathrm{~cm}$, villous; bracteoles lanceolate, acuminate, caducous; pedicels $5-8 \mathrm{~mm}$; sepals subequal, $8-12 \mathrm{~mm}$, ovate, acute, grey-tomentose; corolla $3-6 \mathrm{~cm}$, subcampanulate to broadly funnel-shaped, white(?), densely pilose with appressed hairs, limb $2.5-3.5 \mathrm{~cm}$ diam. Capsule (immature) $6-7 \times 3-4 \mathrm{~mm}$, narrowly ovoid, glabrous.

TYPIFICATION. Various collections are cited by Meisner for his alpha variety paniculata which should be taken as the type variety. We have designated Regnell III 192 (BR) from Martius' herbarium as lectotype as this carries Meisner's annotation which the Lund collection at BR does not. Another hand has added the locality "Villa do Caxu" to the label of this specimen. There is a good isolectotype at Kew.
DISTRIBUTION \& HABITAT. Apparently uncommon in both the cerrados of Brazil and Bolivia; in Bolivia only known from a single collection from the Noel Kempff Park, apparently growing by the path to the meseta.

SPECIMENS eXAMINed. BoliviA. Santa Cruz: Prov. Velasco, PNNKM, Camp. Huanchaca 2, camino hacia la pista, 14 $31^{\prime} 27^{\prime \prime S}, 60^{\circ} 44^{\prime} 40^{\prime \prime} \mathrm{W}, 600$ m, 8 March 1997, S. Jiménez Ẽ E. Gutiérrez 1274 (USZ).

CONSERVATION STATUS. The Bolivian population is an outlying colony from the main populations in Brazil. No information is available about the size of the Bolivian population but it lies within a protected area and faces no current, obvious threat. Without further information it can only be classified as Data Deficient (DD).

PHENOLOGY. Found in flower in March during the summer rainy season.

NOTES. A little known species distinguished from Ipomoea haenkeana by its more woolly indumentum, ovate leaves and longer sepals.

32. Ipomoea cuneifolia Meisn. (Meisner 1869: 245). Type: Brazil, Goiás, 17 Jan. 1829, Burchell 8501-2 (holotype BR 0000006972578!, isotype K000612804!, barcode ambiguously placed).

Erect undershrub to $1.5 \mathrm{~m}$, stem woody, hispid-pilose with multicellular hairs, roots tuberous. Leaves subsessile, 3-6 $\times 1.2-2 \mathrm{~cm}$ oblong-oblanceolate, apex rounded and mucronate, base cuneate and slightly asymmetric, adaxially densely grey-pubescent, abaxially hispidhirsute and gland-dotted, petioles $0-5 \mathrm{~mm}$. Inflorescence terminal, simple, short to somewhat elongate, formed of shortly pedunculate cymes from the uppermost leaf axils; peduncles $0.5-1 \mathrm{~cm}$, diminishing in size upwards; bracteoles up to $6 \times 2$ $\mathrm{mm}$, linear-lanceolate, caducous; pedicels $3-5 \mathrm{~mm}$ so cymes congested; sepals similar, 5 - $7 \mathrm{~mm}$, ovateelliptic, obtuse, grey-tomentellous, slightly accrescent in fruit; corolla $4 \mathrm{~cm}$, funnel-shaped, pink, appressed pilose, limb c. $3 \mathrm{~cm}$ diam., shallowly lobed. Capsule c. $10 \times 6 \mathrm{~mm}$, narrowly ovoid, glabrous; seeds woolly.

DISTRIBUTION \& HABITAT. Scattered through the cerrados of central Brazil, this species is only known from cerrado or campo humedo near Flora de Oro in the Noel Kempff Mercado National Park very close to the Brazilian border.

SPECIMENS EXAMINED. BOLIVIA. Santa Cruz: Prov. Velasco, PNNKM, Flor de Oro, 1333'03"S 61 03'31"W, 200 m, 25 May 1994, E. Gutiérrez 1144 (ARIZ, USZ); ibid., 1333'S 6100' 30"W, 190 m, 20 June 1991, M. Nee 41113 (NY); ibid., margen del Río Iténez, 200 m, M. Peña et al. 88 (FTG).

CONSERVATION STATUS. The Bolivian population is an outlying colony from the main populations in Brazil. No information is available about the size of the Bolivian 
population but it lies within a protected area and faces no current, obvious threat. Without further information it can only be classified as Data Deficient (DD).

PHENOLOGY. Found in flower in Bolivia at the end of the summer rainy season.

NOTES. Close to Ipomoea haenkeana but leaves $<2 \mathrm{~cm}$ wide, densely pubescent adaxially and inflorescence simple, side branches absent or very short.

33. Ipomoea aprica House (1908: 243).

Ipomoea angustifolia Choisy (1845: 355), non I. angustifolia Jacq. (Jacquin 1788). Type: Pohl in Herb. Mart. (holotype M-0184918; isotype K000612793).

Erect undershrub from a xylopodium to c. $75 \mathrm{~cm}$, stems strigose, woody, not usually branched. Leaves sessile, rather numerous, $1.5-12 \times 0.2-0.5 \mathrm{~cm}$, linear to narrowly oblong, base cuneate, apex acute and mucronate, adpressed pubescent. Inflorescence terminal, usually short (c. $5 \mathrm{~cm}$ long) with a distinct rhachis, somewhat compact; flowers solitary from the upper leaf axils or in very shortly pedunculate cymes; peduncles $0-5 \mathrm{~cm}$, pubescent; bracteoles c. $2 \mathrm{~mm}$, lanceolate, fugacious; pedicels $3-10 \mathrm{~mm}$, pubescence more spreading than on peduncles; sepals subequal, $4-6 \mathrm{~mm}$ (accrescent to $7 \mathrm{~mm}$ in fruit), ovate to suborbicular, obtuse to subacute, tomentose, the inner c. $1 \mathrm{~mm}$ longer, rounded with wide, glabrous, scarious margins; corolla $4-4.5 \mathrm{~cm}$, funnel-shaped, pink, adpressed pilose, limb $2.5-3 \mathrm{~cm}$ diam. Capsule ovoid, 5 $7 \mathrm{~mm}$ long, glabrous, shortly rostrate; seeds not seen.

DISTRIBUTION \& HABITAT. A characteristic cerrado species which is quite common in Brazil but much rarer in Paraguay and Bolivia, where it is only known from $500-850 \mathrm{~m}$ in two separate locations on the meseta of the Serranía de Huanchaca of the Noel Kempff Park.

SPECIMENS EXAMINED. BOLIVIA. Santa Cruz: Prov. Velasco, PNNKM, Huanchaca 1, 135' $41^{\prime \prime S ~ 6048 ' 46 " W, ~} 500$ m, $28 \mathrm{Jan} .1997$, A. Soto et al. 415 (FTG, MO, USZ); PNNKM, Las Gamas, 1448'17"S, 60²3'14"W, 850 m, 25 Feb. 1997, Y. Uslar et al. 657 (USZ).

CONSERVATION STATUS. The Bolivian populations are outlying colonies from the main populations in Brazil. No information is available about the size of either but they lie at opposite ends of the Noel Kempff Mercado National Park within a protected area and face no current, obvious threat. Without further information this species can only be classified as Data Deficient (DD).

PHENOLOGY. In Bolivia it has only been collected in January and February at the height of the summer rainy season.
NOTES. This species might be confused with Ipomoea schomburgkii because of its linear leaves but both the corolla and sepals are hirsute. From I. pinifolia, it is distinguished by the subequal sepals and hirsute corolla and sepals.

34. Ipomoea mendozae J. R. I. Wood Ev R. W. Scotland, sp. nov. Type: Bolivia, Santa Cruz, Prov. Vallegrande, Guadelupe, $350 \mathrm{~m}$ de la represa sobre senda a La Estancia Collana, M. Mendoza E E. Calzadilla 416 (holotype USZ; isotype $\mathrm{K}$ ).

http:/ /www.ipni.org/urn:lsid:ipni.org:names:77148121-1

Perennial herb, stems decumbent or ascending, $0.5-1.5$ $\mathrm{m}$ long, relatively stout and slightly woody, densely white-tomentose. Leaves petiolate, $5-11.5 \times 2.5-7 \mathrm{~cm}$, ovate to subrhomboid, acute and shortly mucronulate, base truncate to broadly cuneate, adaxially grey-green, densely pubescent with long hairs, abaxially greytomentose; petioles $0.5-2 \mathrm{~cm}$, tomentose. Inflorescence subterminal formed of pedunculate $1-3(-5)$-flowered cymes from the upper leaf axils; bracts similar to the leaves but smaller, diminishing in size upwards, peduncles $6-12 \mathrm{~cm}$, white-tomentose; secondary peduncles $1-1.5 \mathrm{~cm}$, bracteoles $5-8 \mathrm{~mm}$, linear to filiform; pedicels $5-12 \mathrm{~mm}$, tomentose; sepals subequal, $8-10 \times 3-4 \mathrm{~mm}$, ovate-elliptic, obtuse, outer densely tomentose, the inner similar but with scarious, glabrous margins; corolla $5.5-8 \mathrm{~cm}$ long, pink, funnel-shaped, in bud tomentose on exterior, at maturity somewhat glabrescent but with pubescent midpetaline bands, limb $5.5-6 \mathrm{~cm}$ wide, shallowly lobed; stamens included, filaments slightly unequal, glabrous apart from the hirsute expanded basal part, the hairs short, spreading, fleshy, shorter filaments c. 20 $\mathrm{mm}$, longer c. $25 \mathrm{~mm}$, anthers $4 \times 0.5 \mathrm{~mm}$; style c. $25 \mathrm{~mm}$ long, glabrous, stigma obscurely lobed, ovary glabrous. Capsule and seeds not seen. Figs 7D - E, 9.

RECOGNITION. Although clearly recognisable as part of the radiation of species centred on the Chaco because of its pilose corolla and subequal, tomentose sepals, this species lacks obvious close relatives. The combination of scrambling habit, ovate-subrhomboid, discolourous, tomentose leaves, subterminal inflorescence with 1 - 5-flowered cymes and ovate sepals 8 $10 \mathrm{~mm}$ long serve to distinguish it from all species known to us.

DISTRIBUTION \& HABITAT. Endemic to the Vallegrande area in the Bolivian inter-Andean valleys where it grows in open grassy scrubland on hillsides from 1900 to $2200(-2500) \mathrm{m}$. Map 10.

SPeCimens examined. BoliviA. Santa Cruz: Prov. Vallegrande, $5 \mathrm{~km}$ SW of Vallegrande, $18^{\circ} 31^{\prime} \mathrm{S} 64^{\circ} 08^{\prime} \mathrm{W}$, 2500 m, 10 Jan. 1989, I. Vargas 33 (NY); between 


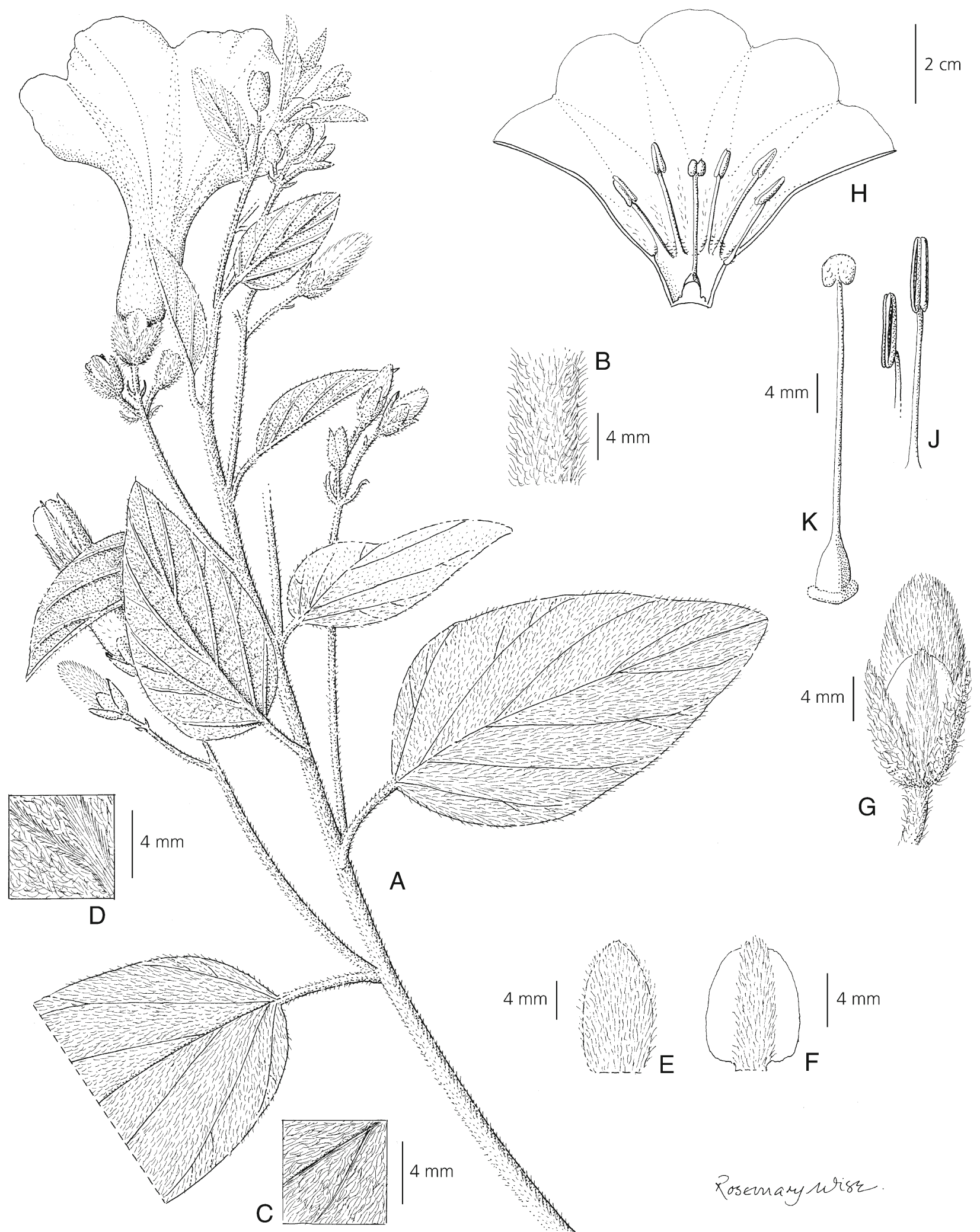

Fig. 9. Ipomoea mendozae. A habit; B portion of stem showing indumentum; C adaxial leaf surface; D abaxial leaf surface; E outer sepal; F inner sepal; G calyx with flower bud; H corolla opened out to show stamens; J anthers; K ovary and style. From Mendoza \& Calzadilla 416. DRAWN BY ROSEMARY WISE. 


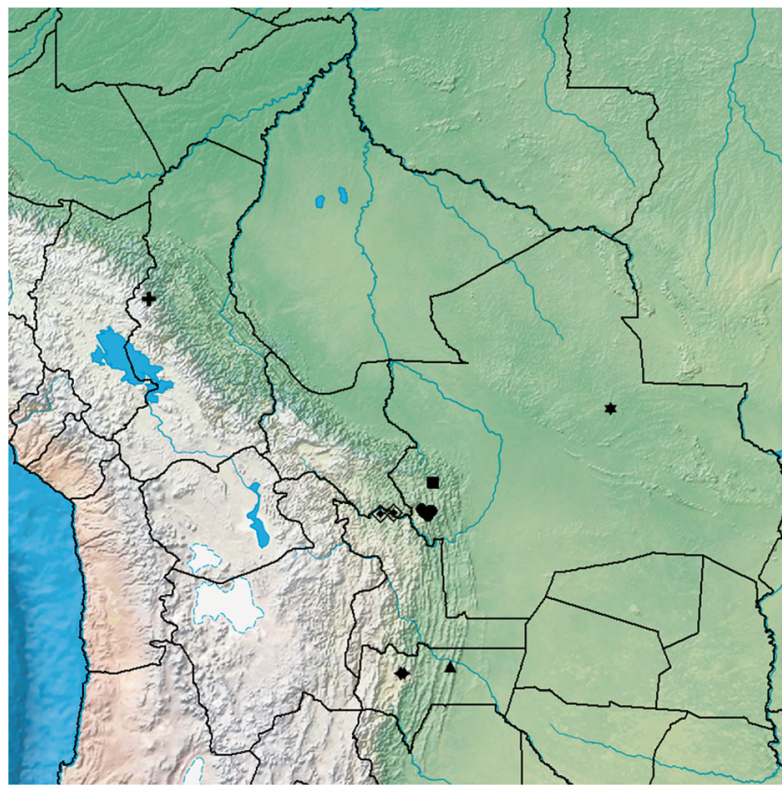

Map 10. Distribution of eight pinpoint endemics: Ipomoea chiquitensis ( being the only example from the eastern lowlands, the others being Andean, concentrated in the south of Bolivia: I. huayllae (廿), I. odontophylla ( $\square$ ), I. mendozae (0), I. juliagutierreziae $(\diamond)$, I. tarijensis $(\bullet)$ and I. appendiculata (A).

Mataralcito and El Palmar on road to Tierras Nuevas, 18³2'30"S 63 57'W, 2150 m, 29 Dec. 1988, M. Nee et al. 37406 (NY); Guadelupe, $350 \mathrm{~m}$ de la represa sobre senda

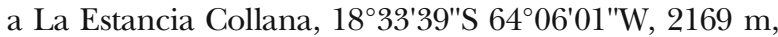
18 Jan. 2003, M. Mendoza E E E. Calzadilla 416 (K, USZ); bajando a Piraimiri en camino de Vallegrande a Piraimiri, 18 37'41"S 6400'41"W, 1908 m, 4 March 2005, J. R. I. Wood et al. 21743 (LPB); camino Vallegrande-Postrervalle, 18 32'39"S 6358'40"W, 1964 m, 1 Feb. 2013, G. A. Parada et al. 5326 (USZ).

CONSERVATION STATUS. Using Geocat this species has an area of occupancy of a little over $112 \mathrm{~km}^{2}$ and it should be classified as Endangered (EN). There are only six known locations in a relatively well-studied area and at least one of these consisted of a single plant so, although population sizes are not accurately known they may be very small. On the positive side there are no obvious direct threats to these populations but the plant does not grow on roadsides or similar disturbed habitats and so could be vulnerable to habitat change.

PHENOLOGY. Flowers during the summer rains from late December to March.

ETYMOLOGY. This species is named after Moises Mendoza, one of the younger generation of Bolivian botanists, who has an outstanding eye for unusual plants and is a very promising taxonomist. Amongst many plants he has found is the species described above.

NOTES. This appears to be a rather isolated species morphologically. The subterminal inflorescence suggests it is essentially erect or ascending in habit as indicated by most field notes. However it is unlike most erect species in South America in its broad leaves and Andean habitat. Broad leaves are a feature of many trailing species (Ipomoea psammophila described in this paper being a good example) from the lowlands but these have obviously axillary inflorescences and differ in a range of other characters.

35. Ipomoea mucronifolia J. R. I. Wood E $R$. W. Scotland, sp. nov. Type: Bolivia, Santa Cruz, Prov. Chiquitos, entre Limoncito y Roboré, J. R. I. Wood E̊ P. Pozo 25064 (holotype USZ, isotypes K, LPB).

http://www.ipni.org/urn:lsid:ipni.org:names:77148122-1

Trailing perennial; stem densely villous, glabrescent when old. Leaves petiolate, mostly $4-8 \times 4-8 \mathrm{~cm}$, shallowly cordate with the base broadly cuneate, auricles rounded, $3(-5)$-lobed, the 4 th and 5 th lobes often poorly developed, lobes broadly ovate, elliptic or obovate, often overlapping, acute or obtuse and strongly mucronate wth mucro $2-3 \mathrm{~mm}$ long, densely grey appressed-pilose on both surfaces but abaxially paler; petioles $2.5-7 \mathrm{~cm}$, softly pilose. Inflorescence of pedunculate, (2 -) 3-flowered, axillary cymes; peduncles $5.5-14 \mathrm{~cm}$, pilose; bracteoles $3-7 \times 1 \mathrm{~mm}$, lanceolate, scarious, pilose, somewhat persistent; secondary peduncles $0.6-1.8 \mathrm{~cm}$; pedicels $0.6-1.2 \mathrm{~cm}$, pilose; sepals minutely gland-dotted on the exterior, dissimilar, outer $12-14 \times 4 \mathrm{~mm}$, broadly lanceolate, shortly acuminate, adpressed-pilose; inner $13-14 \times 5$ $\mathrm{mm}$, oblong-obovate, rounded to acute, the central region pubescent, marginal part broad, glabrous, margin sparsely ciliate; corolla $5.5-6 \mathrm{~cm}$ long, pink, funnelshaped, the limb c. $5 \mathrm{~cm}$ diam., distinctly lobed with ovate acute lobes, densely pilose in bud but somewhat glabrescent, the midpetaline bands thinly pilose on open corollas; stamens included, filaments unequal, glabrous except for pubescent basal expanded part, shorter filaments $10 \mathrm{~mm}$, longer $16 \mathrm{~mm}$, anthers $5.5 \times 1$ $\mathrm{mm}$, linear; style $19 \mathrm{~mm}$, glabrous, stigma distinctly bilobed, ovary glabrous. Capsule and seeds not seen. Fig. 10 .

RECOGNITION. Ipomoea mucronifolia is part of the radiation of species centred on the Chaco and is somewhat similar to I. pseudocalystegia Hassl. in its palmately-lobed, softly hirsute, strongly mucronate leaves, combined with the lanceolate, acuminate sepals. It differs in the smaller, more deeply divided, less silvery leaves, the inflorescence of 3flowered cymes (flowers not solitary), shorter bracteoles (up to $7 \mathrm{~mm}$ long, not $>20 \mathrm{~mm}$ ) and corolla $<6 \mathrm{~cm}$ in length. 


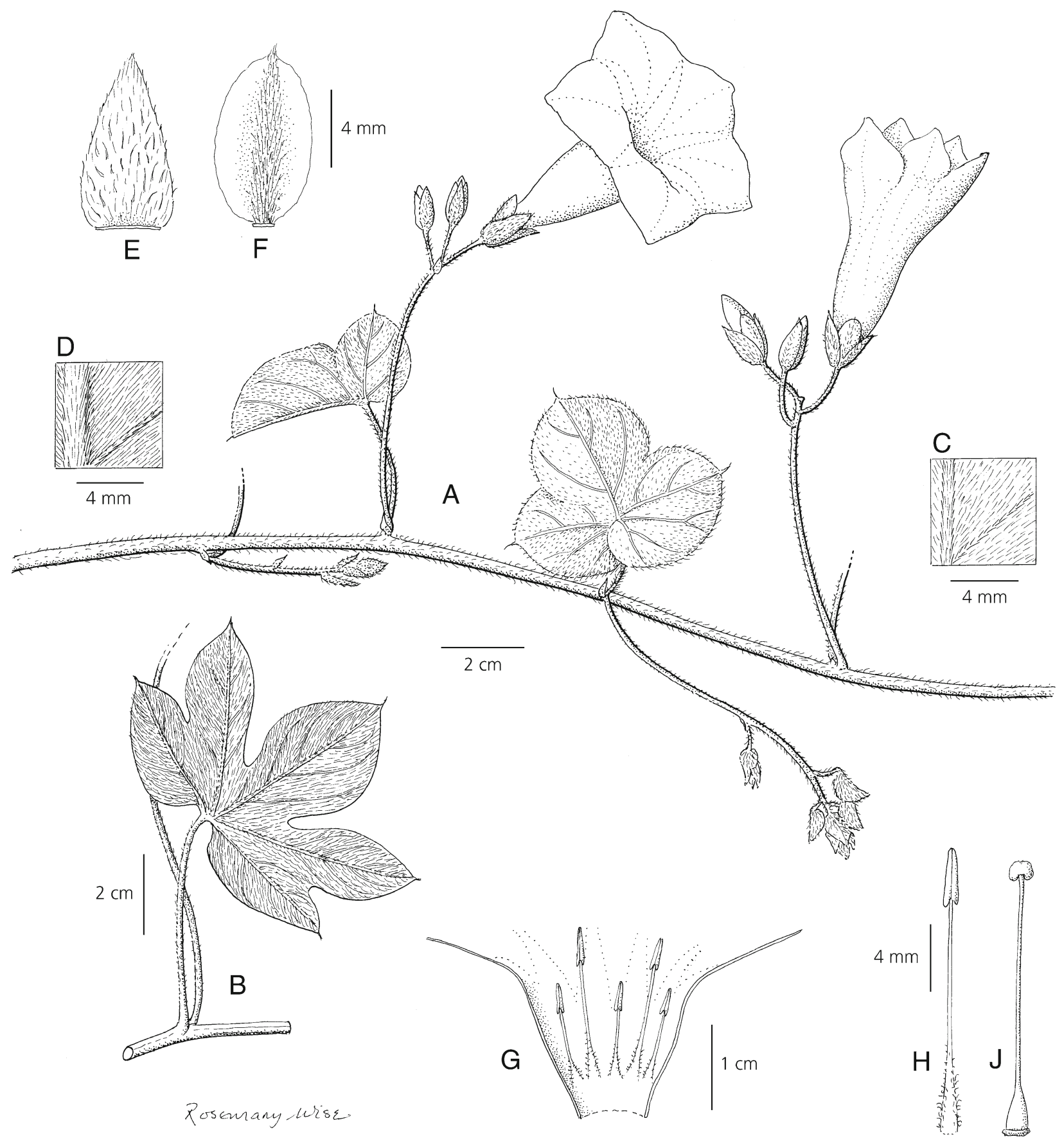

Fig. 10. Ipomoea mucronifolia. A habit; B leaf; C adaxial leaf surface; D abaxial leaf surface; E outer sepal; $F$ inner sepal; $G$ corolla opened out to show stamens; H stamen; J ovary and style. A, C - J from Wood \& Pozo 25064; B from Fuentes \& Navarro 2319. DRAWN BY ROSEMARY WISE.

DISTRIBUTION \& HABITAT. A Bolivian endemic species collected twice in somewhat degraded bushland derived from dry forest with Chaco influence near Roboré around $250 \mathrm{~m}$. The data is so limited that it is difficult to generalise about the real ecology and flowering period of this species.

SPeCimens examined. BoliviA. Santa Cruz: Prov. Chiquitos, entre Limoncito y Roboré, $18^{\circ} 16^{\prime} 29^{\prime \prime S}$
5950'16"W, 252 m, 5 Oct. 2008, J. R. I. Wood E $P$. Pozo 25064 (K, LPB, USZ); Prov. Cordillera, PN Kaa-Iya del Gran Chaco, Estancia el Cañon, 1901'15"S 60¹6'23"W, 250 m, 15 Feb. 1998, A. Fuentes $\mathcal{E} G$. Navarro 2319 (MO, NY, USZ).

CONSERVATION STATUS. Although collcted in two separate locations, the population in the Limoncito location was very small and attempts to refind this species have 
been unsuccessful. Clearly further search at the right season may result in the discovery of other populations in the extensive, but little-known Chaco south of Roboré so this species should be treated as Data Deficient (DD). However, this may well need to be revised to Critically Endangered (CR) if searches prove unsuccessful.

PHENOLOGY. Collected in flower in October and February.

ETYMOLOGY. The name "mucronifolia" refers to the prominent mucronate tips of the leaf lobes.

NOTES. The two collections of this species are slightly different. Fuentes E Navarro 2319 being more densely pilose and with more obviously acuminate sepals but they coincide in other features. Without further collections it is impossible to know the full range of morphological variation.

36. Ipomoea psammophila J. R. I. Wood E $R$. W. Scotland, sp. nov. Type: Bolivia, Santa Cruz, Prov. Chiquitos, entrando hacia Motacú por San Juanama, near Santiago de Chiquitos, J. R. I. Wood, D. Soto, P. Pozo, W. Hawthorne E $\mathcal{E}$ D. Villarroel 25122 (holotype USZ, isotypes $\mathrm{K}, \mathrm{LPB}, \mathrm{UB})$.

http://www.ipni.org/urn:lsid:ipni.org:names:77148123-1

Vigorous trailing perennial; rootstock, woody, forked; stems angled, obscurely bifariously puberulent, glabrescent. Leaves shortly petiolate, ovate, elliptic to suborbicular, apex emarginate and mucronate, obtuse or rounded, base truncate to very shallowly cordate, margin entire, green and glabrous on both surfaces, petioles $3-9 \mathrm{~mm}$, glabrous to pubescent. Inflorescence of $(1-2-) 3(-5)$-flowered axillary cymes; peduncles $1.5-9 \mathrm{~cm}$, glabrous to very thinly pubescent; secondary peduncles (when present) $7-8 \mathrm{~mm}$; bracteoles $1.5 \times 0.5 \mathrm{~mm}$, lanceolate, obtuse, caducous leaving a semi-circular scar; pedicels $3-10 \mathrm{~mm}$, pubescent; sepals subequal, 11 $12 \mathrm{~mm}$ long, outer sepals narrowly ovate, obtuse to subacute, puberulent to pubescent, inner sepals ovate-elliptic, thinly to densely pubescent, c. $1 \mathrm{~mm}$ longer, margins scarious; corolla $5-7 \mathrm{~cm}$, pink, funnel-shaped, in bud pubescent, limb c. $7 \mathrm{~cm}$ wide, shallowly lobed; stamens included, filaments unequal, glabrous apart from the pubescent expanded basal part, shorter $12-13 \mathrm{~mm}$, longer 20 $21 \mathrm{~mm}$; anthers linear, $4 \times 0.5 \mathrm{~mm}$; style $1.7 \mathrm{~cm}$, glabrous, stigma subglobose. Capsule $13 \times 10 \mathrm{~mm}$, ovoid, rostrate with mucro $1.5 \mathrm{~mm}$ long, glabrous; seeds $7 \times 3.5$ $\mathrm{mm}$, oblong, brown, glabrous, minutely scaly on margin. Figs 11B, 12.

RECOGNITION. This species resembles Ipomoea nitida Griseb., particularly forms from Corrientes Province in
Argentina, but the leaves are glabrous or obscurely pubescent, their base cordate to truncate, rather than truncate to cuneate, the petioles very short $(0.3-0.9 \mathrm{~cm}$, not $2-4 \mathrm{~cm})$, the cymes usually $1-$ 3-flowered (not up to 7-flowered) and the sepals green, pubescent, rather than grey-tomentellous, 11 $12 \mathrm{~mm}$ (not $7-9 \mathrm{~mm}$ ) long. The glabrous seeds may also be distinctive.

DISTRIBUTION \& HABITAT. A Bolivian endemic species which is locally common around Santiago de Chiquitos and present but, less abundantly, south of Taperas along the old road to Roboré. It grows in cerrado on sandy soil both on the mesetas around Santiago and on more low lying cerrados. Map 15.

SPECIMENS eXAmined. BoliviA. Santa Cruz: Prov. Chiquitos, meseta de la Serranía de Santiago, $18^{\circ} 19^{\prime} 25^{\prime \prime S} 59^{\circ} 34^{\prime} 14^{\prime \prime} \mathrm{W}, 850 \mathrm{~m}, 26$ Nov. 1999, R. Guillén et al. 4799 (MO, USZ); $5 \mathrm{~km} \mathrm{E}$ of Taperas on old road to Chochís, $400 \mathrm{~m}, 28$ Dec. 1999, J. R. I. Wood E D. J. Goyder 15668 (K, LPB); $1 \mathrm{~km}$ from Santiago de Chiquitos along road to Roboré, $18^{\circ} 20^{\prime} \mathrm{S} 59^{\circ} 36^{\prime} \mathrm{W}, 650 \mathrm{~m}, 24 \mathrm{Jan}$. 2001, J. R. I. Wood E D. J. Goyder 16928 (K, LPB, USZ); ibid., 4 Dec. 2003, J. R. I.Wood et al. 20171 (BOLV, $\mathrm{K}, \mathrm{LPB}, \mathrm{USZ}$ ); On the serranía near el Arco, Santiago de Chiquitos, $18^{\circ} 20^{\prime} \mathrm{S} 59^{\circ} 33^{\prime} \mathrm{W}, 700 \mathrm{~m}, 15$ April 2004, J. R. I. Wood 20691 (BOLV, K, LPB, USZ); TCO Santa Teresita, $18^{\circ} 20^{\prime} \mathrm{S} 60^{\circ} 30^{\prime} \mathrm{W}$ (approx.), 402 m, 17 Dec. 2004, J. B. Alchorn et al. 58 (USZ); camino viejo de Taperas a Roboré, c. $4 \mathrm{~km}$ de Taperas, $18^{\circ} 02^{\prime} 31^{\prime \prime} \mathrm{S} 60^{\circ} 24^{\prime} 34^{\prime \prime} \mathrm{W}, 502 \mathrm{~m}, 17$ Oct. 2007, J. R. I. Wood et al. 23578 (K, LPB, UB, USZ); medio kilometro de la plaza de Santiago sobre camino a Roboré, $18^{\circ} 20^{\prime} 27^{\prime \prime} \mathrm{S} 59^{\circ} 36^{\prime} 15^{\prime \prime} \mathrm{W}, 617$ m, 22 Oct. 2007, J. R. I. Wood et al. 23674 (K, LPB, UB, USZ); entrando hacia Motacú por San Juanama, $18^{\circ} 19^{\prime} 01^{\prime \prime S} 59^{\circ} 13^{\prime} 43^{\prime \prime} \mathrm{W}, 660 \mathrm{~m}, 15$ Oct. 2008, J. R. I. Wood et al. 25122 (K, LPB, UB, USZ); entering $0.5 \mathrm{~km}$ from San Juanama from Roboré-Santiago road, $18^{\circ} 19^{\prime} 13^{\prime \prime S} 59^{\circ} 37^{\prime} 38^{\prime \prime} \mathrm{W}, 647$ m, 21 April 2013, J. R. I. Wood E B. Williams 27903 (LPB, OXF, USZ); Santiago de Chiquitos, between cemetery and old airfield, $18^{\circ} 21^{\prime} 05^{\prime \prime S} 59^{\circ} 38^{\prime} 08^{\prime \prime} \mathrm{W}$, 590 m, 11 Jan. 2014, J. R. I. Wood 27910 (K, LPB, OXF, USZ).

CONSERVATION STATUS. Using Geocat this species has an area of occurrence of about $1,050 \mathrm{~km}^{2}$ and should be classified as Endangered (EN). Since it is only known from two separate areas in a relatively well-studied region it seems unlikely that this classification will need to be revised. The populations near Taperas are relatively small, although others are more likely to be found in this area. Those near Santiago de Chiquitos are more threatened. Already populations in the area of San Juanama near Santiago have been destroyed by 

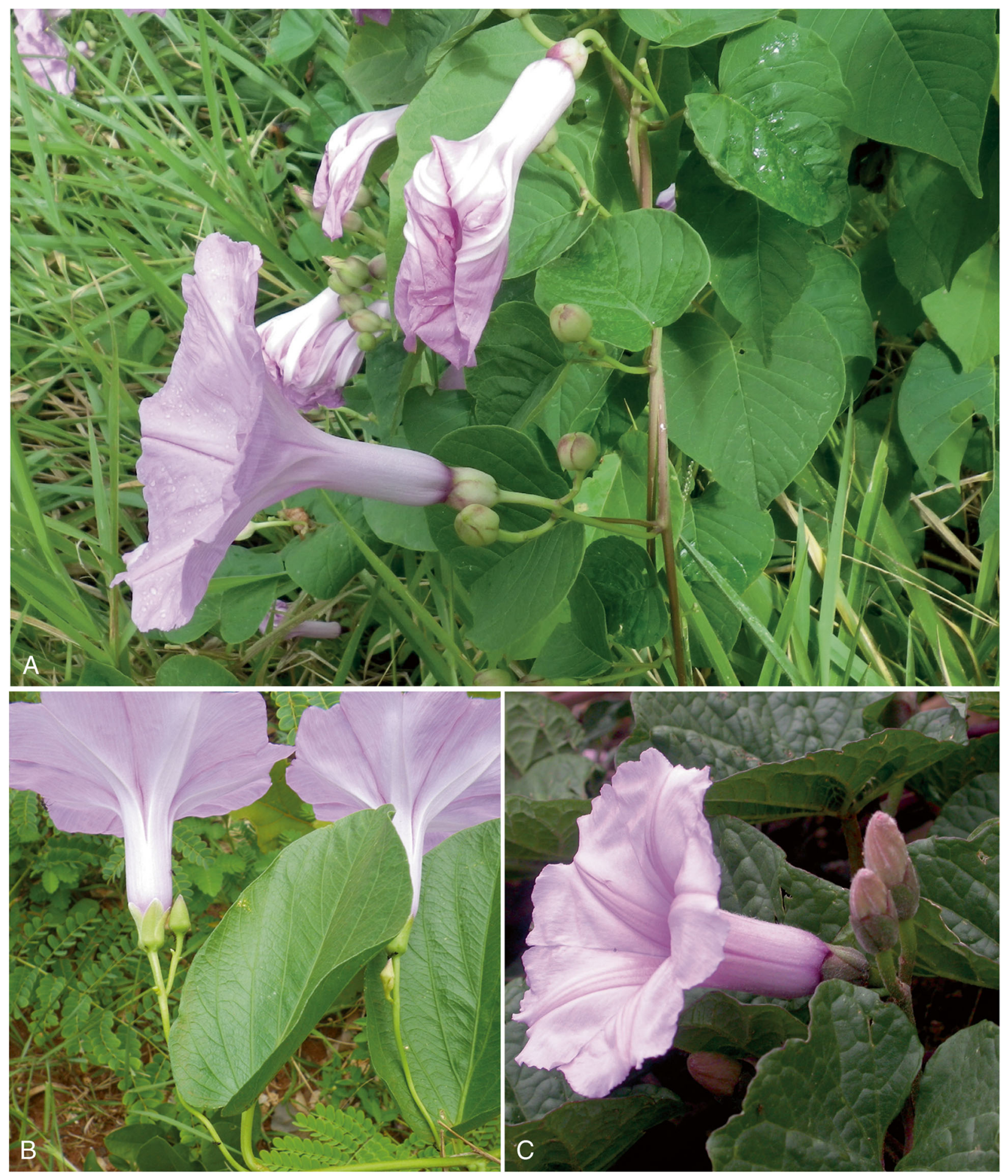

Fig. 11. A Ipomoea chondrosepala; B I. psammophila; C I. lilloana. PHOTOS: A - B JOHN WOOD; C DARWIN INITIATIVE PROJECT 162/11/010.

conversion of cerrado to seeded pasture and others are threatened by urbanisation around Santiago. Fortunately the populations on the mesetas of the region are likely to be immune from the ravages of development.
PHENOLOGY. Can be found in flower throughout the summer rainy season but most intensively from October to January.

ETYMOLOGY. The epithet psammophila meaning sandloving refers to its preference for sandy habitats. 


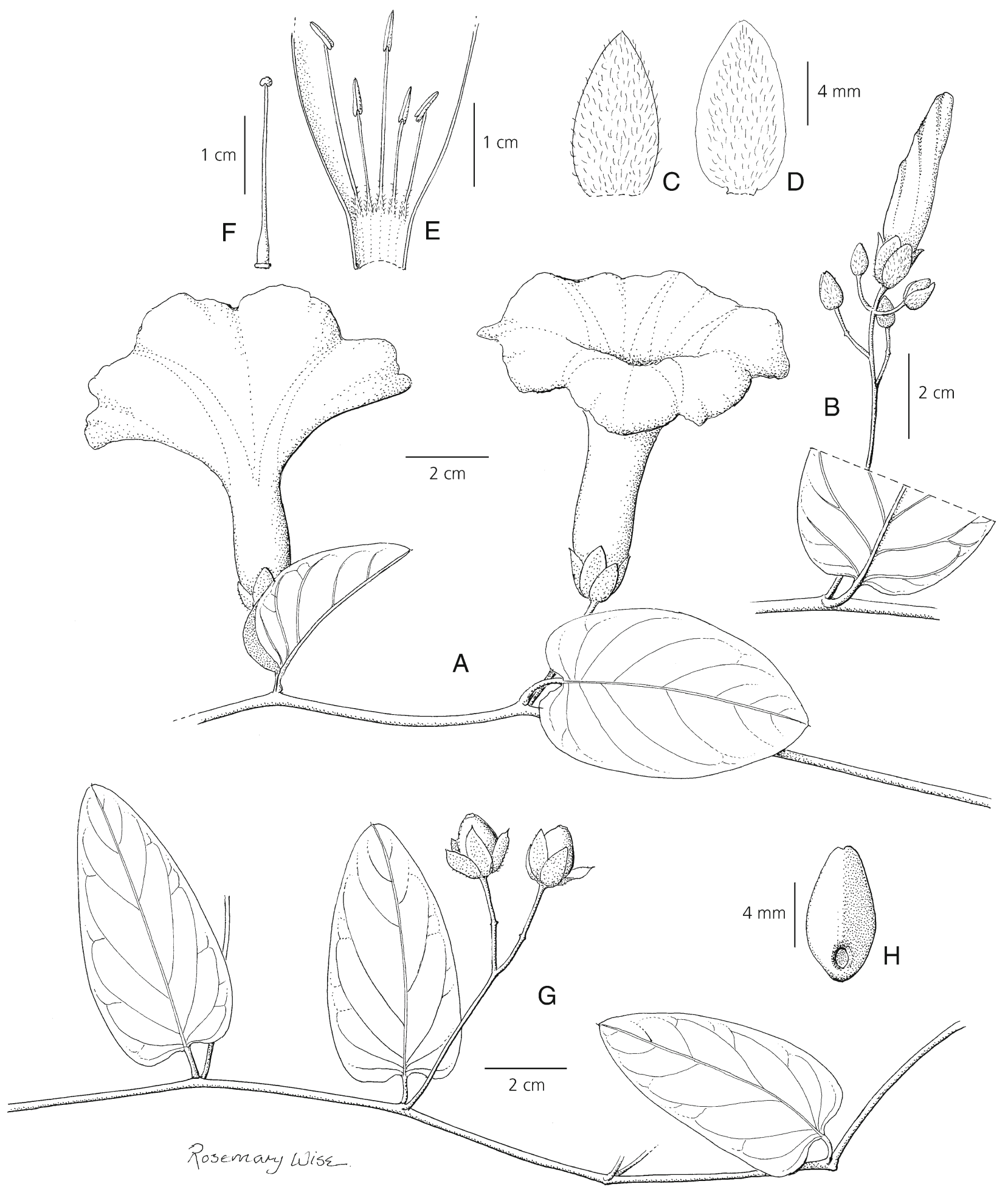

Fig. 12. Ipomoea psammophila. A habit; B flowering shoot; C outer sepal; D inner sepal; E corolla opened out to show stamens; $F$ ovary and style; G habit showing fruiting inflorescence with capsule; H seed. A, C - F from Wood 20691; B from Wood et al. 23578; G - H from Wood 27910. DRAWN BY ROSEMARY WISE.

NOTES. Within the Bolivian context this is a very distinctive species on account of its trailing habit, shortly petiolate, glabrous to thinly pubescent, ovate to suborbicular leaves. In the wider context of the Chaco region it is part of a complex of species which includes Ipomoea uruguayensis 
Meisn. and I. chodatiana O'Donell as well as I. nitida.

37. Ipomoea lilloana O'Donell (1948: 182). Type: Argentina, Salta, Dep. Campo Santo, Juramento, C. O'Donell 4910 (holotype LIL!).

Trailing perennial herb, stems sparsely pubescent, somewhat stout and slightly fleshy, up to $2 \mathrm{~m}$ long, rootstock stout, tuberous. Leaves petiolate, $3-7 \times 3-$ $7 \mathrm{~cm}$, ovate-deltoid, ovate or suborbicular, obtuse to acute, base broadly cordate to subtruncate, the margin undulate to dentate, white-canescent when young but when mature adaxially dark green and glabrous, abaxially puberulent especially on the veins; petioles $1.5-3.5 \mathrm{~cm}$, thinly pubescent. Inflorescence of shortly pedunculate 1-3-flowered cymes; peduncles $1-7.5 \mathrm{~cm}$; bracteoles not known, fugacious; pedicels $5-10 \mathrm{~mm}$; sepals slightly unequal, $8-10 \times 6-7 \mathrm{~mm}$ at anthesis but accrescent to $13 \mathrm{~mm}$ in fruit, ovate-elliptic, pubescent, outer sepals subacute, inner sepals slightly longer, scarious-margined, obtuse to rounded, sometimes mucronate; corolla $4-7 \mathrm{~cm}$, funnel-shaped, pink, densely adpressed pilose, limb $5-6.5 \mathrm{~cm}$ diam., unlobed. Capsule $1.5 \times 0.8 \mathrm{~mm}$, ovoid, acute to rostrate, glabrous; seeds $9 \times$ $4 \mathrm{~mm}$, densely woolly. Fig. 11C.

DISTRIBUTION \& HABITAT. Although described from Argentina this species is more common in Bolivia where it is found in scattered localities between about $1600 \mathrm{~m}$ and $2600 \mathrm{~m}$ in the inter-Andean dry valleys. It is usually found in small populations on open stony slopes and is nowhere common.

SPECIMENS EXAMINED. BOLIVIA. Chuquisaca: Prov. Oropeza, c. $20 \mathrm{~km}$ above Puente Arce towards Chuquichuqui, 1600 m, 27 Dec. 1995, J. R. I. Wood 10252 (HSB, K, LPB). Cochabamba: Prov. Campero, Pasorapa, en el camino a Com. Kinori, $18^{\circ} 13^{\prime} 44^{\prime \prime} \mathrm{S}$ $64^{\circ} 19^{\prime} 13 " \mathrm{~W}, 2388 \mathrm{~m}, 25$ March 2003, J. R. I. Wood et al. 19483 (K, LPB); 35 - $40 \mathrm{~km}$ de Aiquile hacia Lagar Pampa, 18²0'55"S 6505'29"W, 2456 m, 26 Jan. 2005, J. R. I. Wood E M. Mendoza 21515 (BOLV, K, LPB, OXF, USZ); c. $15 \mathrm{~km} \mathrm{~N}$ of Omereque along road to Totora, $17^{\circ} 58^{\prime} 30^{\prime \prime} \mathrm{S} 64^{\circ} 59^{\prime} 16^{\prime \prime} \mathrm{W}, 2252 \mathrm{~m}, 24$ Nov. 2006, J. R. I. Wood E N. P. Taylor 22521 (K, LPB); Prov. Carrasco, Totora, Huerto Molino, 2200 m, Jan. 1951, M. Cardenas 4674 (LIL); Prov. Mizque, on ridge 10 $15 \mathrm{~km} \mathrm{~N}$ of Río Mizque on road from Aiquile to Totora, 2600 m, 21 Feb. 1998, J. R. I. Wood 13026 (K, LPB). Santa Cruz: Prov. Caballero, $3 \mathrm{~km} \mathrm{NE}$ of Abra de Quine, $18^{\circ} 04^{\prime} \mathrm{S} 64^{\circ} 19^{\prime} 30^{\prime \prime} \mathrm{W}, 2100 \mathrm{~m}, 31$ Dec. 1995, M. Nee 46632 (NY, USZ). Tarija: Prov. Gran Chaco, Palos Blancos, c. 1985, M. Lewis s.n. (F). Prov. O'Connor, pasando Puente Aruma sobre el Río Pilaya, hacia Timboy, $\left.20^{\circ} 54^{\prime} 55^{\prime \prime S} 64^{\circ} 06^{\prime} 41^{\prime \prime}\right), 1683 \mathrm{~m}$, 30 Dec. 2005, M. Serrano et al. 7114 (HSB).
CONSERVATION STATUS. Including its limited presence in Argentina this species has a considerable area of occurrence at slightly over $135,000 \mathrm{~km}^{2}$ and should be classified as Least Concern (LC) on this basis. However, the scattered records reflect what is probably a genuine distribution pattern, Ipomoea lilloana only occuring in small populations in scattered locations. Although there is no clear threat to its habitat, it is difficult to predict its presence and it is certainly absent from many places where it might be expected. It merits careful study to discover the full extent of its distribution and to understand why its populations are so small. It may eventually need reclassifying as Vulnerable (VUL).

PHENOLOGY. Flowers soon after substantial rain between November and May.

NOTES. Readily identified by its trailing habit, stout stem, thinly pubescent, undulate leaves, pubescent sepals and corolla. Although the leaves are variable in shape, there is no other similar species in the interAndean valleys.

38. Ipomoea chondrosepala Hallierf. (Hallier 1899b: 49). Type: Paraguay, Villa Rica, Balansa 1072 (lectotype P, designated here, isolectoypes $\mathrm{G}, \mathrm{K}$ ).

Liana reaching $6 \mathrm{~m}$, stems glabrous. Leaves petiolate, $6-11 \times 4-9 \mathrm{~cm}$, ovate, base broadly cordate to subtruncate, apex very shortly acuminate, margin often denticulate near base, both surfaces glabrous, veins prominent abaxially; petioles $3-6 \mathrm{~cm}$. Inflorescence of few-flowered, pedunculate, axillary cymes; peduncles straight, $3-10 \mathrm{~cm}$; bracteoles caducous; secondary peduncles $2-2.5 \mathrm{~cm}$; pedicels $1-3 \mathrm{~cm}$; sepals somewhat unequal, broadly oblong, rounded to retuse (sometimes mucronulate), glabrous, margins scarious, outer sepals $10-12 \times 6 \mathrm{~mm}$; inner sepals $12-16 \times 7-8 \mathrm{~mm}$; corolla $6-9.5 \mathrm{~cm}$ long, funnelshaped, pink, in Bolivia usually pubescent in bud and at tips of midpetaline bands, sometimes completely glabrous, limb $3-4 \mathrm{~cm}$ diam., weakly lobed. Capsule $15-16 \times 11-12 \mathrm{~mm}$, ovoid, glabrous; seeds $6 \times 3.5 \mathrm{~mm}$, woolly. Fig. 11A.

TYPIFICATION. Hallier cited two types, Balansa 1072 and Hassler 742. The Berlin duplicates he presumably saw were destroyed in 1943 and none of the specimens we have seen at $\mathrm{G}, \mathrm{K}$ and $\mathrm{P}$ are annotated by him. We have selected the Paris specimen of Balansa 1072 as lectotype as it is the best specimen we have seen. Paris seems to have received the top set of Balansa's collections.

DISTRIBUTION \& HABITAT. Found in scattered localities in Bolivia, southern Brazil and Paraguay. In Bolivia it grows in disturbed bushy ground along the Andean foothills up to about $1100 \mathrm{~m}$ north to Ballivian 
province in the Beni, avoiding the very humid Chapare region and perhaps most common on the Chaco fringes.

SPECIMENS SEEN. BOLIVIA. Beni: Prov. Ballivian, Misión Fatima, S de San Borja, Río Maniqui con Río Chimane, 240 m, 28 May 1988, S. G. Beck et al. 16643 (F, LPB). Chuquisaca: Prov. Luis Calvo, Vaca Guzman, pie de Serranía de Incahuasi hacia Com. Arrayan, $19^{\circ} 52^{\prime} 47^{\prime \prime S} 63^{\circ} 44^{\prime} 16^{\prime \prime W}, 1020$ m, 17 Feb. 2006, A. Lliully E Portal 725 (HSB, MO, OXF). Cochabamba: Prov. Chapare, Espiritu Santo, 1891, M. Bang 1278 (GH, K, MO, NY, US). La Paz: Prov. Sud Yungas, Alto Beni, Sapecho-Santa Ana, 470 m, 21 May 1988, R. Seidel E Schulte 2424 (LPB). Santa Cruz: Prov. Cordillera, Camiri, 800 m, Feb. 1951, M. Cardenas 4734 (LIL); c. $4 \mathrm{~km}$ del camino principal de Abapó entrando a la Com. Morocco, 18 52'01"S 6322'52"W, 487 m, 24 April 2012, J. R. I. Wood Ẽ F. Mamani 27477 (K, LPB, OXF, USZ); entre Abapó y Laguna Tatarenda, en el camino de Santa Cruz a Camiri, $19^{\circ} 03^{\prime} 13^{\prime \prime S}$ 6328'01"W, 786 m, 23 March 2013, J. R. I. Wood et al. 27590 (K, LPB, USZ); camino entre Ipati y Lagunillas, en dirección a Muyupampa, 1947'22"S 6339'38"W, 1070 m, 29 March 2013, J. R. I. Wood et al. 27637 (K, LPB, OXF, USZ). Prov. Ibañez, La Angostura on Santa Cruz-Samaipata highway, $18^{\circ} 10^{\prime} \mathrm{S}, 63^{\circ} 31^{\prime} \mathrm{W}, 775 \mathrm{~m}, 20$ April 2002, M. Nee E $M$. Sundue 52209 (MO, NY); Reserva Arubaí, $8 \mathrm{~km}$ de Terebinto, $17^{\circ} 41^{\prime} \mathrm{S} 63^{\circ} 25^{\prime} \mathrm{W}$, 225 m, 25 May 2006, D. Villarroel $\mathcal{E}$ I. Linneo s.n. (USZ). Prov. Ichilo, Buenavista, $450 \mathrm{~m}$, June 1915, J. Steinbach 1424 (LIL); ibid., 10 May 1916, J. Steinbach 2733 (LIL); trail along Río Yapacani towards Camp. Mataracu, $17^{\circ} 32^{\prime} \mathrm{S} 63^{\circ} 52^{\prime} \mathrm{W}, 350 \mathrm{~m}, 31$ May 1998, M. Nee Eं L. Bohs 49535 (MO, NY, US, USZ); vic. Hotel Flora y Fauna, $5 \mathrm{~km} \mathrm{SE}$ of Buenavista, 17³0'36"S 6338'57"W, 385 m, 24 April 2005, M. Nee 52914 (MO, NY); c. 2 km del centro de Buena Vista en el camino a Yapacani, 17²1'11"S 6340'24"W, 398 m, 4 April 2013, J. R. I. Wood E B. Williams 27735 (K, LPB, USZ). Prov. Nuflo de Chávez, $3-5 \mathrm{~km} \mathrm{E}$ of Monte Verde, $15^{\circ} 15-30^{\prime} \mathrm{S} 62^{\circ} 15-30$ 'W, 250 m, 25 May 1993, M. Saldias et al. 2555 (FTG, MO). Tarija: Prov. Gran Chaco, Yacunda, camino hacia Campo Largo, 2201'16"S 6357'27"W, $650 \mathrm{~m}$, F. Zenteno et al. 4454 (LPB); ibid., Palos Blancos, $2 \mathrm{~km}$ towards Villamontes, $21^{\circ} 25^{\prime} 05^{\prime \prime S} 63^{\circ} 45^{\prime} 49^{\prime \prime} \mathrm{W}, 734 \mathrm{~m}, 26$ Nov. 2007, M. Mendoza 2662a (K).

CONSERVATION STATUS. Based on its extent of occurrence this species should be classified as Least Concern (LC), but it should be noted that individual populations are small and it may be less common than its range would suggest.

PHENOLOGY. Most commonly found in flower in the February - June period.

NOTES. Not always easily distinguished from Ipomoea philomega but the leaves are always glabrous, the inflorescence is few-flowered, and the corolla is larger $(6-9.5 \mathrm{~cm})$, gradually widened from the base and often pubescent at the tips of the midpetaline bands.

It has been suggested that this species is conspecific with Ipomoea pandurata (L.) G. Mey. from the United States but, although somewhat similar morphologically, molecular studies using ITS give no support for this. Additionally I. chondrosepala has a longer corolla and the leaves are always ovate and unlobed, rather than deltoid and often lobed.

The protologue indicates that the corolla is glabrous externally and this is confirmed by examination of the lectotype collection. Recent collections from Paraguay, for example B. Jiménez Ė M. Peña 1237 (BM, CTES) also have glabrous corollas but in Bolivia the corolla seems always to be pubescent on the midpetaline bands in bud although no other differences have been observed apart from a slightly larger corolla.

39. Ipomoea cardenasiana O'Donell (1950a: 375). Type: Brazil, Mato Grosso, Urucúm, M. Cardenas 4448 (holotype LIL!).

Vigorous twining perennial to $3 \mathrm{~m}$; stems stout, glabrous. Leaves petiolate, $4-10 \times 3-8 \mathrm{~cm}$, mostly 3-lobed to half way with acute lobes but some leaves ovate with one or two marginal teeth, base broadly cordate, apex shortly acuminate and mucronate, adaxially glabrous apart from veins pubescent near base, abaxially paler, pubescent especially on the veins; petioles $2-5 \mathrm{~cm}$. Inflorescence of pedunculate, axillary cymes; peduncles $2-5 \mathrm{~cm}$, stout, glabrous; bracteoles c. $5 \mathrm{~mm}$ long, oblong, mucronate, papery, caducous; secondary and tertiary peduncles $0.8-1.5 \mathrm{~cm}$; pedicels $5-10 \mathrm{~mm}$, pubescent; sepals slightly unequal, outer $15-20 \times 10-12 \mathrm{~mm}$, ovate, narrowed to an obtuse apex, minutely puberulent, pale green; inner sepals 18 $22 \times 12 \mathrm{~mm}$, elliptic, acuminate to an obtuse apex, sericeous, pallid; corolla $7-9 \mathrm{~cm}$ long, funnel-shaped, pale pink, pubescent in bud, glabrescent later, limb $5 \mathrm{~cm}$ diam., very shallowly lobed. Capsule ovoid, $15 \times 10 \mathrm{~mm}$, glabrous, brown, enclosed by sepals; seeds $11 \times 6 \mathrm{~mm}$ (possibly immature), brown, pilose with very long marginal hairs. Fig. 13A.

DISTRIBUTION \& HABITAT. Although this species is not endemic - its distribution straddles the border with Brazil — it is effectively a pinpoint endemic to the Corumbá-Puerto Suárez area where it is locally common on scrubby roadsides around $100-$ $150 \mathrm{~m}$.

SPecimens examined. BoliviA. Santa Cruz: Prov. Germán Busch, camino entre Puerto Suárez y Cerro Mutún, 19¹0'27"S 5754'32"W, 150 m, 28 March 2009, J. R. I. Wood E D. Villarroel 25902 (K, LPB, UB, USZ); 

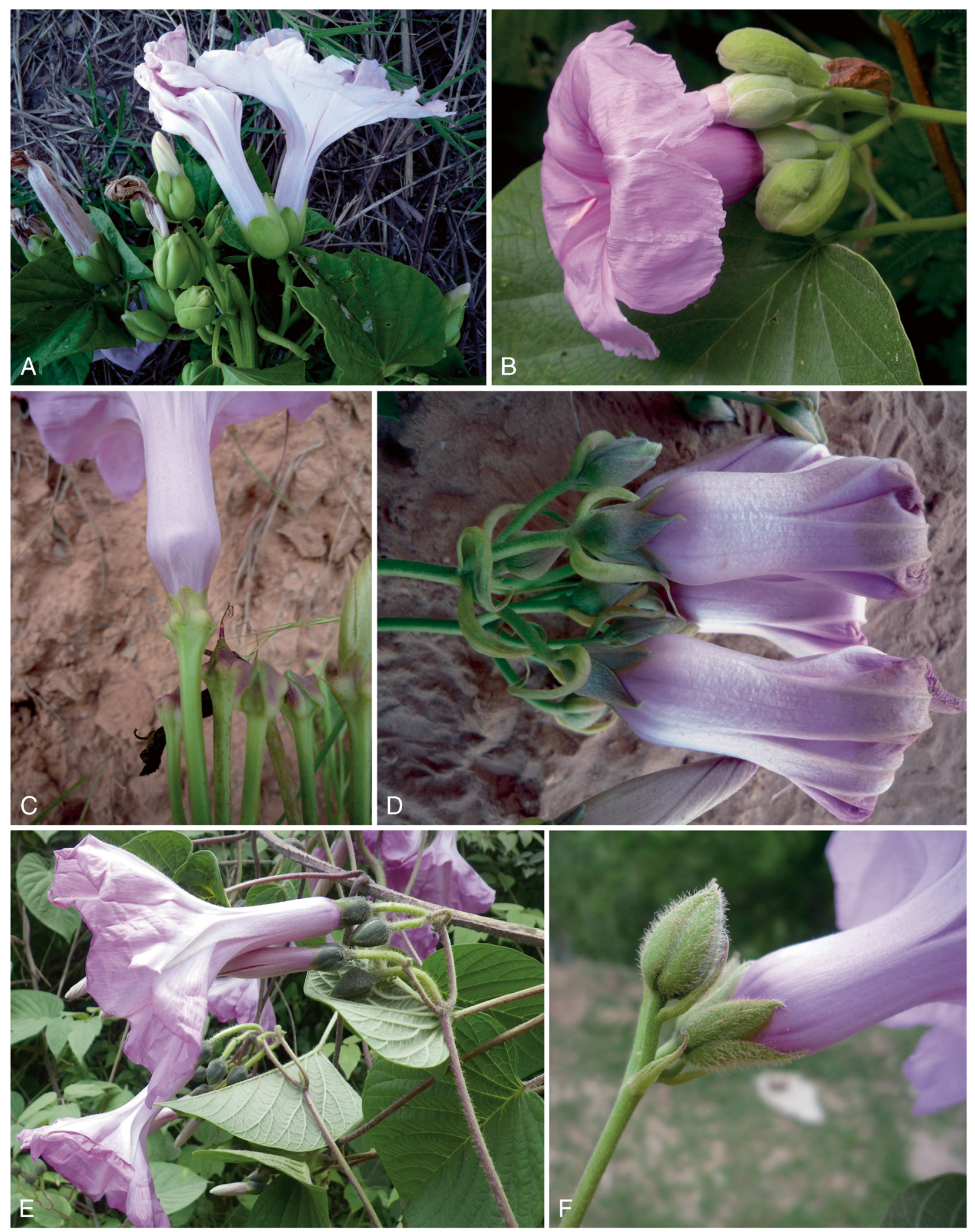

Fig. 13. A Ipomoea cardenasiana; B I. calyptrata; C I. appendiculata; D I. argentinica; E I. spinulifera; F I. longibarbis. PHotos: A, C D, F BETH WILLIAMS; B DARWIN INITIATIVE PROJECT 162/11/010; E JOHN WOOD. 
near Matacucito village between Yacuses and Puerto Suárez, 1859'13"S 5750'09"W, 139 m, 19 April 2013, J. R. I. Wood et al. 27885 (K, LPB, USZ); $10 \mathrm{~km} \mathrm{~W}$ of Puerto Suárez on road to Carmen Rivero Tórrez, 18 59'20"S 5752'09"W, $130 \mathrm{~m}, 19$ April 2013, J. R. I. Wood et al. 27887 (K, LPB, USZ).

CONSERVATION STATUS. A narrowly endemic species to the Corumbá-Puerto Suárez region. Its exact range in Brazil is not known but its range is so restricted that it should be categorised as Endangered (EN). Fortunately it seems to thrive on roadsides so is obviously tolerant of disturbance.

PHENOLOGY. It has been collected in flower in March and April.

NOTES. A very distinctive species because of its large corolla, acutely 3-lobed leaves and large pale green sepals.

40. Ipomoea vivianae Krapov. (Krapovickas 2009: 57). Type: Argentina, Salta, Dep. Rivadavia, Pluma del Pato, 13 Feb. 2005, V. Solis Neffa, J. G. Seijo, J. G. Grabiele $\mathcal{E}$ W. Reynoso 1985 (holotype CTES!, isotypes LIL!, SI).

Twining perennial to at least $3 \mathrm{~m}$, stems glabrous or sparsely pubescent when young, becoming woody with corky bark when old. Leaves petiolate, $2-4 \times$ $2.5-5.5 \mathrm{~cm}$, broadly ovate to subreniform, abruptly acuminate, shallowly cordate, glabrous or very thinly pubescent, abaxially somewhat paler; petioles $2-4 \mathrm{~cm}$, slender. Inflorescence of shortly pedunculate axillary cymes, often raceme-like on short side branches; peduncles short, $1-2 \mathrm{~cm}$, commonly somewhat woody; bracteoles $2 \mathrm{~mm}$, caducous; secondary peduncles 5 $10 \mathrm{~mm}$; pedicels 10 - $16 \mathrm{~mm}$; sepals subequal, outer $6-8 \times 3-4 \mathrm{~mm}$, ovate-elliptic, subacute, thinly pubescent, inner sepals c. $1 \mathrm{~mm}$ longer, rounded, the central part pubescent but with glabrous scarious margins; corolla $4-5 \mathrm{~cm}$, funnel-shaped, white, sometimes with pink centre, pubescent in bud and on midpetaline bands, limb $3-4 \mathrm{~cm}$ diam., unlobed. Capsule ovoid, $8 \times 6 \mathrm{~mm}$, glabrous, rostrate, the style base persistent; seeds $5 \mathrm{~mm}$ long, long-pilose.

DISTRIBUTION \& HABITAT. A Chaco species found in northern Argentina, Paraguay and Bolivia. In Bolivia it is apparently rare but may have been overlooked.

SPeCimens eXAmined. BOliviA. Santa Cruz: Prov. Cordillera, Est. Cerro Colorado, 10 Dec. 1993, G. Navarro 2122 (MO, USZ); cruce del camino San JoséSalinas con el gaseoducto $17^{\circ} 56^{\prime} 08^{\prime \prime S} 60^{\circ} 47^{\prime} 29^{\prime \prime W}, 230 \mathrm{~m}$, 26 Aug. 1997, A. Fuentes E G. Navarro 2016 (NY); PN KaaIya, $58 \mathrm{~km} \mathrm{~W}$ of Camp. San José on the gaseoducto, $18^{\circ} 27^{\prime} 31^{\prime \prime S}, 61^{\circ} 22^{\prime} 53^{\prime \prime} \mathrm{W}, 230 \mathrm{~m}, 13$ June 1998, A. Fuentes $\mathcal{E}^{\circ}$ G. Navarro 2418 (BOLV, LPB, MO, NY, USZ). Tarija:
Gran Chaco, Mun. Villamontes, Puesto El Pelicano, 16 June 2010, P. Zuñiga et al. 175 (HSB).

A. Gentry et al. 75199 (LPB, MO, NY, USZ) from Curuyuqui, Río Parapeti, (1845'56"S 62¹3'59"W) may also belong here but is sterile.

CONSERVATION STATUS. Data deficient. A recently described and poorly known species found in three countries. Although there are few records from Bolivia, the Chaco is extensive and largely unexplored botanically so this species may prove to be more common than the few records suggest.

PHENOLOGY. Found in flower in Bolivia from June to August during the winter dry season.

NOTES. This species resembles Ipomoea chiliantha and I. amnicola in habit and leaf shape but is distinguished by its white flowers, pubescent corolla and sepals, and by the corky bark on old stems. Although Krapovickas (2009: 59) compared it to I. lilloana O'Donell and both species belong to the Chaco radiation, they do not appear to be closely related.

41. Ipomoea argentinica Peter (1891: 30). Type: Argentina, Salta, pasaje del Río Juramento, Lorentz $\mathcal{E}^{\circ}$ Hieronymus 285 (lectotype GOET 005548!, designated by O’Donell (1959b: 110), isolectotype US!).

Twining or, less commonly, trailing perennial, roots with small tubers, stems densely pubescent. Leaves petiolate, mostly $2-8 \times 3-10 \mathrm{~cm}$, broadly ovate to suborbicular, shallowly cordate to \pm truncate with rounded auricles, apex acute and apiculate, adaxially green and appressed pilose, abaxially grey, tomentose with long, appressed hairs; petioles $1-8 \mathrm{~cm}$. Inflorescence of dense pedunculate cymes; peduncles $4-7(-11) \mathrm{cm}$, usually grey-tomentellous; bracteoles $1.2-2 \times 0.1-0.3 \mathrm{~cm}$ long, linear-lanceolate, longacuminate, grey-tomentose, persistent; secondary peduncles $0.3-4 \mathrm{~cm}$; pedicels $0-10 \mathrm{~mm}$, often very short, tomentellous; sepals subequal, $9-10 \times 4-5 \mathrm{~mm}$, broadly lanceolate, acute to acuminate, silvery-sericeous, the inner ovate with scarious, glabrous margins; corolla $5-7 \mathrm{~cm}$, pale pink, adpressed-pilose, funnelshaped, limb 3-4 cm diam., undulate to very shallowly lobed. Capsule ovoid, $8-9 \times 7 \mathrm{~mm}$, glabrous; seeds $6-$ 7 mm long, long-pilose. Figs 13D, 14J - P.

DISTRIBUTION \& HABITAT. A species of the western Chaco in northern Argentina, western Paraguay and SE Bolivia. It is a lowland species of roadsides and disturbed bushy habitats, not found above $600 \mathrm{~m}$. It is particularly common around the city of Santa Cruz and its distribution in Bolivia is broadly similar to that of Ipomoea reticulata and I. abutiloides. Map 11.

SELECTED SPECIMENS OF 26 eXAMINED. BOLIVIA. Santa Cruz: Prov. Chiquitos, Tres Cruces, 17³6'12"S 62 14'01"W, 290 m, 21 April 2013, J. R. I. Wood $\mathcal{E}^{2} B$. 


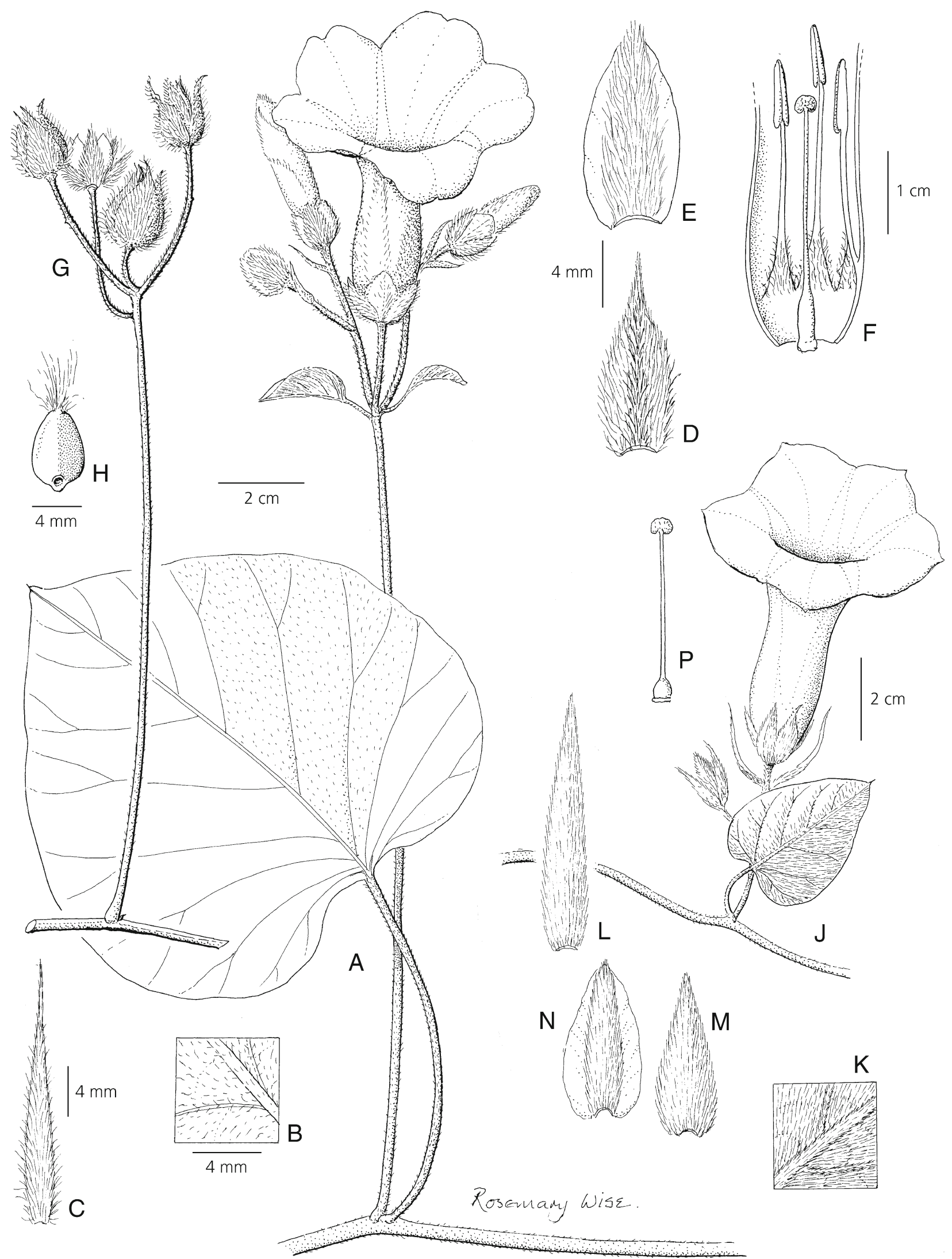

Fig. 14. A-H /pomoea longibarbis. A habit; B abaxial leaf surface; C bracteole; D outer sepal; $E$ inner sepal; F section of corolla showing 3 stamens, ovary and style; $\mathrm{G}$ fruiting inflorescence; $\mathrm{H}$ seed. J - P /pomoea argentinica J inflorescence; K abaxial leaf surface; L bracteole; M outer sepal; $\mathrm{N}$ inner sepal; P ovary and style. A - F from Nee \& Linneo 54148; G - H from Killeen et al. 4199; J - P from Wood \& Mamani 27502. DRAWNBY ROSEMARY WISE. 


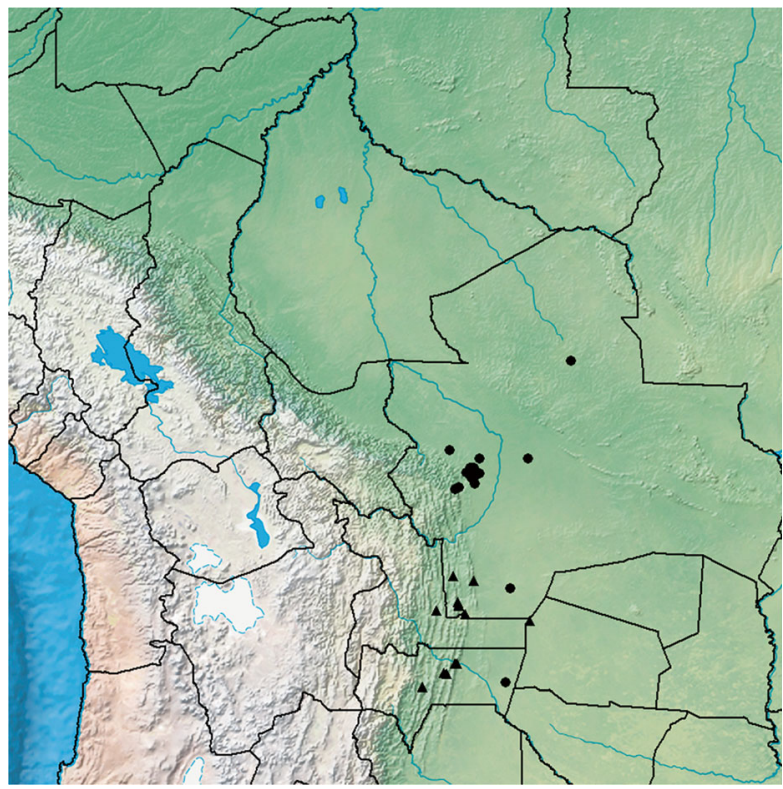

Map 11. Contrasting distributions of Ipomoea argentinica centred on the Santa Cruz area and I. longibarbis ( $\mathbf{A})$, an endemic of the western Chaco.

Williams 27908 (K, LPB, OXF, USZ). Prov. Cordillera, Cordillera, Estación Perforación, 1955'S, 62³3'W, 400 m, 23 March 2001, A. Fuentes 2869 (USZ). Prov. Florida, c. $2 \mathrm{~km}$ above La Angostura on road to Samaipata, $18^{\circ} 10^{\prime} 03^{\prime \prime S} 63^{\circ} 31^{\prime} 32^{\prime \prime W}, 643 \mathrm{~m}, 30$ March 2008, J. R. I. Wood et al. 24101 (K, LPB, UB, USZ). Prov. Ibañez, $13 \mathrm{~km}$ SW of Santa Cruz on highway to Samaipata, $17^{\circ} 52^{\prime} \mathrm{S}, 63^{\circ} 16^{\prime} \mathrm{W}, 450 \mathrm{~m}, 18$ April 1998, M. Nee 49033 (CTES, LPB, MO, NY, USZ). Prov. Ichilo, Buenavista, 450 m, April 1915, J. Steinbach 1272 (LIL). Prov. Sara, $9 \mathrm{~km}$ NW of bridge over Río Piraí at La Bélgica, 17³1'06"S 6316'03"W, 370 m, 21 April 2003, M. Nee Ẽ M. A. Sundue 52222, (LPB, MO, NY, USZ). Prov. Velasco, about $4 \mathrm{~km} \mathrm{~N}$ of Santa Rosa de la Roca on the road to Piso Firme, $15^{\circ} 52^{\prime} 09^{\prime \prime S}$ 61 27'33"W, 380 m, 13 April 2013, J. R. I. Wood et al. 27791 (K, LPB, OXF, USZ). Tarija: Prov. Gran Chaco, Res. Nat. Corbalan, 21 $36^{\prime} 25^{\prime \prime} \mathrm{S}, 62^{\circ} 27^{\prime} 46^{\prime \prime} \mathrm{W}, 267$ m, 10 May 2008, Abrahamczck s.n. (LPB)

CONSERVATION STATUS. Least Concern (LC).

PHENOLOGY. Flowers towards the end of the summer rainy season, principally from March to June.

NOTES. Distinguished from all similar species (Ipomoea hieronymi, I. longibarbis, I. megapotamica) by the very long, persistent bracteoles, which persist until corollas have fallen, those immediately below the calyx being particularly persistent. Additionally, it can be separated from I. longibarbis by the adpressed, \pm sericeous hairs of the sepals and from I. hieronymi by the more acuminate sepals. It has been treated as a synonym of the Brazilian I. sericophylla Meisn. (Staples et al. 2012: 674) but differs in the much longer, persistent bracteoles, much less dense abaxial leaf indumentum and longer sepals.
42. Ipomoea longibarbis J. R. I. Wood E R. W. Scotland, sp. nov. Type: Bolivia, Santa Cruz, Prov. Cordillera, Pie de la Muela del Diablo, Boyuibe-Camiri, J. R. I. Wood, D. Villarroel E B. Williams 27633 (holotype USZ; isotypes $\mathrm{K}, \mathrm{LPB}, \mathrm{OXF}$ ).

http:/ /www.ipni.org/urn:lsid:ipni.org:names:77148124-1

Robust twining perennial usually $2-5 \mathrm{~m}$ high, stems pubescent, somewhat woody. Leaves petiolate, $4-13 \times$ 3 - $12 \mathrm{~cm}$, ovate, acute or shortly acuminate, terminating in a fine hair point, base shallowly cordate to truncate, margin slightly undulate, adaxially green, thinly adpressed-pubescent, abaxially grey, densely pubescent; petioles $3-10 \mathrm{~cm}$, pubescent. Inflorescence of pedunculate axillary cymes with $1-8$ flowers, somewhat dense; peduncle $4.5-26 \mathrm{~cm}$, usually rather stout, pubescent; lower bracteoles $2-2.5 \times 0.2-0.8 \mathrm{~cm}$, oblong to oblong-elliptic; secondary peduncles $1.5-4 \mathrm{~cm}$; upper bracteoles $9-18 \times 1 \mathrm{~mm}$, linear-lanceolate, terminating in a long fine point, pubescent, somewhat persistent; pedicels $2-10 \mathrm{~mm}$, pubescent; sepals slightly unequal, outer $11-16 \times 6-7 \mathrm{~mm}$, ovate, acuminate to a fine point, grey-pilose with conspicuous spreading hairs, inner ovate-elliptic, acute, silvery-pilose with hairs weakly spreading; corolla $8 \mathrm{~cm}$ long, uniformly pink, silky pubescent on the exterior, funnel-shaped, widening above middle, limb $5 \mathrm{~cm}$ diam., shallowly-lobed; stamens included, filaments unequal, glabrous apart from pubescent expanded basal part, shorter filaments $12 \mathrm{~mm}$, longer $15 \mathrm{~mm}$, anthers linear, $3.5 \times 0.5 \mathrm{~mm}$; style $19 \mathrm{~mm}$, glabrous, stigma obscurely bilobed. Capsule $10-$ $11 \times 10 \mathrm{~mm}$, ovoid, glabrous, seeds $7 \times 3-3.5 \mathrm{~mm}$, brown, glabrous apart from the $10 \mathrm{~mm}$ long white marginal hairs. Figs 13F, 14A - H.

RECOGNITION. A species of the Chaco radiation similar to Ipomoea argentinica in habit and leaf indumentum but differing in the laxer inflorescence with longer peduncles, broader outer sepals with conspicuous spreading hairs and less persistent bracteoles. Herbarium specimens resemble $I$. rubens very closely in facies and indumentum but molecular studies indicate there is no close affinity. I. longibarbis is a plant of dry habitats, not stream banks.

DISTRIBUTION \& HABITAT. Endemic to Bolivia. It grows in dry chaco scrub woodland along the Andean foothills from Camiri south to the Villamontes area, between 500 and $1500 \mathrm{~m}$, largely replacing Ipomoea argentinica in this region. Map 11.

SPeCimens examined. BoliviA. Santa Cruz: Prov. Cordillera, $2.2 \mathrm{~km}$ SE of Salinas by turn-off to Charagua, $20^{\circ} 14^{\prime} 23^{\prime \prime} \mathrm{S}, 63^{\circ} 27^{\prime} 19^{\prime \prime} \mathrm{W}, 915$ m, 13 Feb. 2006, M. Nee Eं I. Linneo 54148 (MO, NY, USZ); Camiri-Santa Cruz, $19^{\circ} 42^{\prime} 08^{\prime \prime S} 63^{\circ} 33^{\prime} 54^{\prime \prime W}, 1067$ m, 16 March 2007, M. Atahuachi et al. 1133 (BOLV, LPB); $19 \mathrm{~km} \mathrm{~S}$ of Camiri towards Villamontes, $20^{\circ} 10^{\prime} 45^{\prime \prime} \mathrm{S} 63^{\circ} 28^{\prime} 43^{\prime \prime} \mathrm{W}, 821$ m, 9 Feb. 2008, M. Mendoza et al. 2728 (K, LPB, USZ); 
$19 \mathrm{~km} \mathrm{~S}$ of Camiri towards Villamontes, 20¹0'38"S 6328'42" W, 879 m, 10 Feb. 2008, M. Mendoza et al. 2762 (K, USZ); $24 \mathrm{~km} \mathrm{~S}$ of Camiri towards Villamontes, $20^{\circ} 13^{\prime} 05^{\prime \prime S} 63^{\circ} 27^{\prime} 53^{\prime \prime W}, 879$ m, 10 Feb. 2008, M. Mendoza et al. 2765 (K, LPB, USZ); Charagua, Com. San Francisco, 651 m, 2 April 2011 Estrada E Severiche 319 (HSB); Pie de la Muela del Diablo, Boyuibe-Camiri, 20²3'41"S 6321'07"W, 994 m, 25 March 2013, J. R. I. Wood et al. 27633 (LPB, OXF, USZ). Chuquisaca: Prov. Calvo, $80 \mathrm{~km} \mathrm{E}$ of Boyuibe, Camp. Texaco, 20 $30^{\prime} \mathrm{S}$ $62^{\circ} 10^{\prime} \mathrm{W}, 500 \mathrm{~m}, 19$ June 1992, T. Killeen et al. 4199 (MO). Prov. Siles, Monteagudo-Rosario del Ingre, 20¹9'21"S 6351'32"W, 25 March 1996, M. Serrano 2087 (HSB). Tarija: Prov. Gran Chaco, cerca de Villamontes, March 1952, M. Cardenas 4950 (LIL); $44.5 \mathrm{~km} \mathrm{~W}$ of upper bridge over Río Pilcomayo and $17.7 \mathrm{~km}$ NE of Palos Blancos, 21 ${ }^{\circ} 27^{\prime} \mathrm{S} 63^{\circ} 40^{\prime} 45^{\prime \prime} \mathrm{W}, 815$ m, 21 March 2007 M. Nee E R. Flores 54816 (MO, NY, USZ); Cañon del Río Pilcamayo, $5 \mathrm{~km}$ de Villamontes hacia Palos Blancos, 21 16'02"S 6331'16"W, 405 m, 24 March 2013, J. R. I. Wood et al. 27593 (K, LPB, OXF, USZ); 6 - $7 \mathrm{~km}$ E of Palos Blancos towards Villamontes, 21 ${ }^{\circ} 26^{\prime} 17^{\prime \prime S} 63^{\circ} 43^{\prime} 13$ 'W, 850 m, 24 March 2013, J. R. I. Wood et al. 27622 (K, LPB, USZ). Prov. O'Connor, Alta de Soledad, 21 40'52"S 6406'36"W, $1510 \mathrm{~m}, 3$ March 2006, F. Zenteno et al. 4357 (LPB).

CONSERVATION STATUS. Using Geocat this species should be provisionally classified as Near Threatened (NT), based on its extent of occurrence of little more than $21,000 \mathrm{~km}^{2}$. However, it is plant of open scrub in little danger of clearance and is any case tolerant of disturbance, so no direct threat seems likely. Little is known about the number or size of different populations and a final assessment should await the completion of a detailed study PHENOLOGY. Flowers towards the end of the summer rainy season, principally from February to April, so somewhat earlier than Ipomoea argentinica.

43. Ipomoea appendiculata J. R. I. Wood E $R$. W. Scotland, sp. nov. Type: Bolivia, Tarija, Prov. Gran Chaco, 10 - $20 \mathrm{~km}$ from Villamontes towards Palos Blancos, J. R. I. Wood, D. Villarroel E B. Williams 27607 (holotype USZ; isotypes K, LPB, OXF).

http://www.ipni.org/urn:lsid:ipni.org:names:77148125-1

Vigorous liana climbing over other plants to c. $3 \mathrm{~m}$, stems woody, pale brown, glabrous. Leaves petiolate, slightly succulent and often transversely folded, $5-7 \times$ $4-5 \mathrm{~cm}$, broadly ovate, shallowly cordate with rounded auricles, shortly acuminate to a mucronate apex, margin entire, both surfaces pale green and glabrous; petioles $2-3.5 \mathrm{~cm}$, glabrous. Inflorescence of shortly pedunculate axillary cymes with up to five flowers; peduncles 2 - $3.5 \mathrm{~cm}$, rigid, glabrous; bracteoles $2-4 \times 1 \mathrm{~mm}$, lanceolate, boat-shaped, scurfy puberulent, caducous; secondary and tertiary peduncles $1-2.5 \mathrm{~cm}$; pedicels $(1-) 2.2-3 \mathrm{~cm}$, straight, glabrous below, upwards thickened, scurfy puberulent; sepals subequal, $5-6 \times 3 \mathrm{~mm}$, puberulent, each with two swollen glabrous appendages on each side towards the base, outer sepals acute and mucronate, inner sepals obtuse, minutely mucronate, margins scarious, glabrous; corolla uniformly pink, puberulent in bud, glabrescent at anthesis, $6.5-7 \mathrm{~cm}$ long, funnel-shaped, limb $5 \mathrm{~cm}$ wide, undulate but not lobed; stamens included, filaments slightly unequal, glabrous apart from bearded basal part, shorter filaments $12-14 \mathrm{~mm}$, longer c. $16 \mathrm{~mm}$, anthers linear, $5 \times 0.5 \mathrm{~mm}$; style $3.5 \mathrm{~cm}$, ovary glabrous. Capsule ovoid, $6 \times 7 \mathrm{~mm}$, glabrous; seeds $1.6 \times 1 \mathrm{~mm}$. ovoid, obtuse, brown, glabrous. Figs 13C, 15 .

RECOGNITION. This species shows some similarity to Ipomoea amnicola Morong in the somewhat succulent leaves, these often being deciduous on herbarium specimens, and also to I. tarijensis O'Donell in the commonly folded leaves. However it is more closely related to $I$. hieronymi and $I$. megapotamica but is distinguished by the glabrous leaves. The $5-6 \mathrm{~mm}$ long sepals are shorter than those of I. hieronymi and lack the dark glands sometimes found in that species and in I. megapotamica. The distinctive swollen appendages on the dorsal surface of the sepals immediately separates this species from all others known to us. DISTRIBUTION \& HABITAT. Endemic to southern Bolivia where it grows in chaco scrub in the Andean foothills on a steep stony slope at $600 \mathrm{~m}$. Map 10 .

SPECIMENS EXAMINED. BOliviA. Tarija: Prov. Gran Chaco, 10 - $20 \mathrm{~km}$ from Villamontes towards Palos Blancos, $21^{\circ} 18^{\prime} 50^{\prime \prime S} 63^{\circ} 36^{\prime} 44^{\prime \prime} \mathrm{W}, 631 \mathrm{~m}, 24$ March 2013, J. R. I. Wood et al. 27607 (K, LPB, OXF, USZ).

CONSERVATION STATUS. This species is only known from a single collection and should be categorised provisionally as Data deficient (DD). There is no obvious reason why there might not be other populations in this area but the plant is obviously rare and may turn out to be endangered but this is uncertain without extensive exploration in the vicinity of the type location.

PHENOLOGY. Found in flower in March.

ETYMOLOGY. This species is named "appendiculata" because of the prominent outgrowths on the sepals.

44. Ipomoea hieronymi (Kuntze) O'Donell (1948: 171). Murucoa hieronymi Kuntze (1898: 217). Type: Argentina, Salta. San José, Lorentz Ẽ Hieronymus 220 (holotype $\mathrm{B} \uparrow$, isotypes GOET!, CORD!).

Argyreia megapotamica Griseb. (Grisebach 1879: 263), non Ipomoea megapotamica Choisy (1845). Type: Argentina, Cordoba, Ascochinga, Lorentz s.n. (possible lectotype, fide O'Donell 1948: 179, CORD n.v.). 


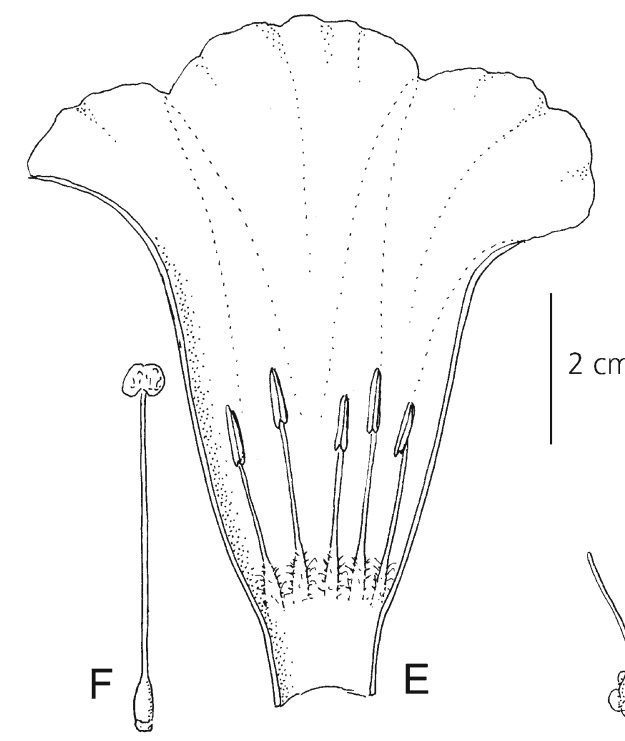

C
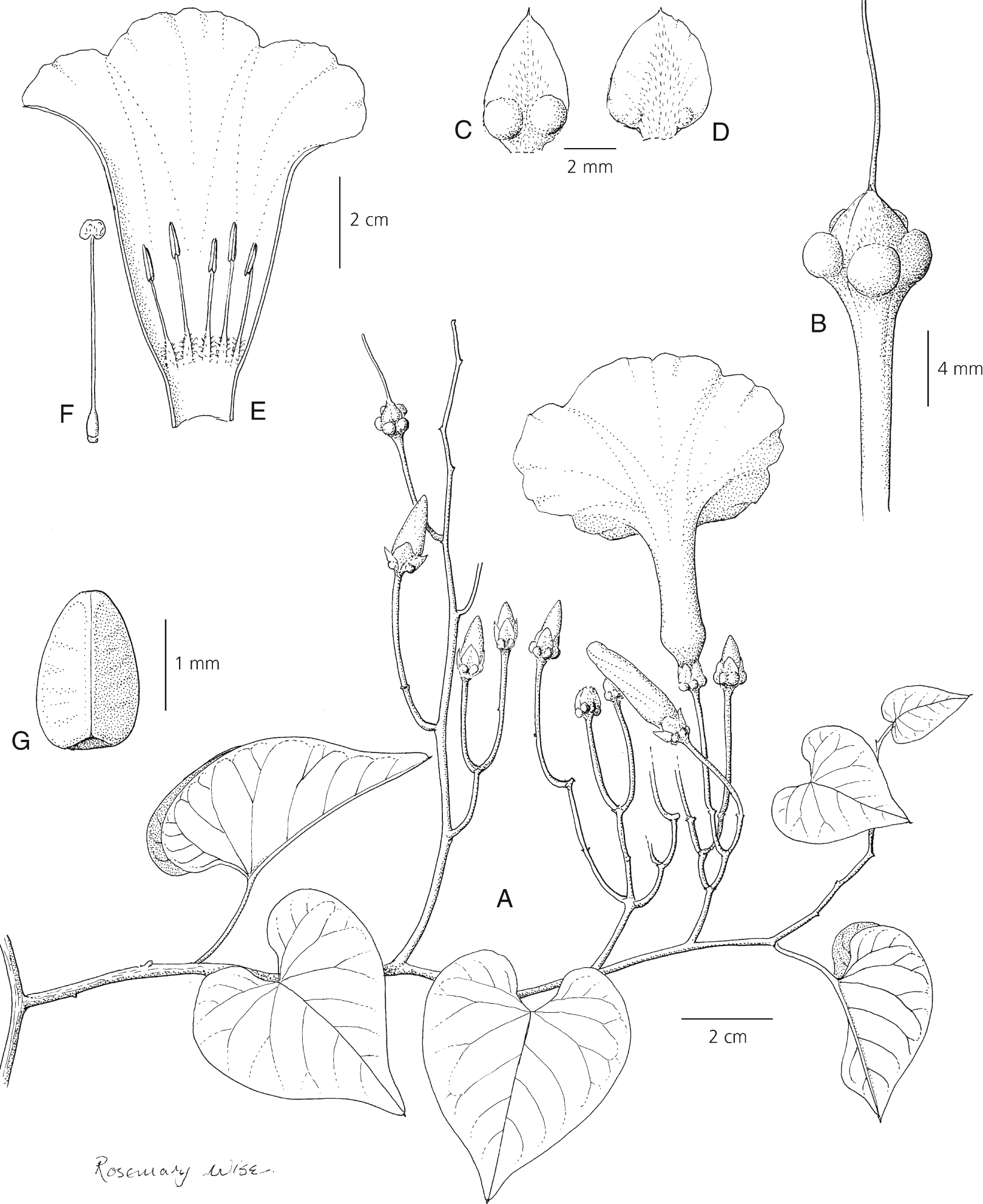

Fig. 15. Ipomoea appendiculata. A habit; B immature fruit showing appendages; C outer sepal; D inner sepal; E corolla opened out to show stamens; F ovary and style; $\mathrm{G}$ seed. From Wood et al. 27633. DRAWN BY ROSEMARY WISE.

Ipomoea kurtziana O’Donell (1948: 179), nom. nov., based on Argyreia megapotamica Griseb.
Ipomoea hieronymi var. kurtziana (O’Donell) O’Donell (1959b: 163). 
Vigorous perennial or liana, stems pubescent to tomentellous. Leaves petiolate, $4-10(-15) \times 4-10$ $(-15) \mathrm{cm}$, ovate, cordate with rounded auricles, apex rounded and mucronate to acute or very shortly acuminate, adaxially dark green and densely puberulent, abaxially white-tomentose; petioles $2-11 \mathrm{~cm}$, densely puberulent or tomentose. Inflorescence of longpedunculate axillary cymes, usually 3 - 5-flowered; peduncles $3-20 \mathrm{~cm}$, tomentose, bracteoles $5 \mathrm{~mm}$ long, ovate, caducous; secondary peduncles mostly 6 - $10 \mathrm{~mm}$; pedicels 5 - $12 \mathrm{~mm}$, tomentose; sepals subequal, $9-11 \times 6-7 \mathrm{~mm}$, ovate, grey-tomentose, often with a dark gland at base, acute to obtuse, inner slightly shorter with scarious margins; corolla $4.5-7 \mathrm{~cm}$, funnel-shaped, pink, tomentellous, limb c. $4 \mathrm{~cm}$ diam. Capsule ovoid, 8 - $10 \mathrm{~mm}$ long, glabrous, seeds $7-8 \mathrm{~mm}$ long, glabrous except sericeous angles.

DISTRIBUTION \& HABITAT. Common in the Andean region of northwestern Argentina extending into the south of Bolivia. It is found from around 700 to 2000 $\mathrm{m}$ in scattered locations by roadsides and along forest margins.

SPECIMENS eXAMINed. BoliviA. Chuquisaca: Prov. Calvo, $31 \mathrm{~km}$ SW de Cuevo, Estancia Morocuapira, 9 Feb. 2008, M. Mendoza et al. 2739 (USZ). Tarija: Prov. Cercado, Tarija, 2000 m, 25 Jan. 1904, K. Fiebrig 2655 (BM, NY, P). Prov. Gran Chaco, Serranía San Alberto, Pozo Petrolero SAL X, 16 Jan. 2001, R. Chávez E $R$. Meneses 2954 (LPB); Palos Blacos, 21 2'05"S 6345'49"W, 734 m, 7 Feb. 2008, M. Mendoza et al. 2898 (USZ). Prov. O'Connor, Cuesta de San Simon, $21^{\circ} 25^{\prime} \mathrm{S} 64^{\circ} 05^{\prime} \mathrm{W}, 30$ April 1983, A. Krapovickas $\mathcal{E}$ A. Schinini 39036 (LPB); Reserva Nacional Tariquía, Com. Salinas, $21^{\circ} 48^{\prime} 24^{\prime} \mathrm{S} 64^{\circ} 23^{\prime} 05^{\circ} \mathrm{W}, 932 \mathrm{~m}, 4$ Feb. 2006, M. Serrano et al. 7609 (LPB); camino a

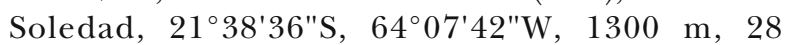
Feb. 2006, F. Zenteno et al. 4218 (LPB); región de Soledad, sendera de la escuela, $21^{\circ} 40^{\prime} \mathrm{S} 64^{\circ} 04^{\prime} \mathrm{W}, 1200 \mathrm{~m}$, 1 March 2006, S. G. Beck et al. 31879 (LPB).

CONSERVATION STATUS. This is a common species in northwestern Argentina and the Bolivian records represent a northern extension. Within Bolivia it might be considered vulnerable based on its extent of occurrence but there are no observed threats and no information about population sizes. It should be provisionally classified as Data Deficient (DD).

PHENOLOGY. In Bolivia found in flower from January to April during the summer rainy season.

NOTES. This species resembles Ipomoea argentinica and similar species in having leaves abaxially whitetomentose. It is close to I. megapotamica, the sepals often with a dark gland near the base but differs in the tomentose leaves and longer sepals, which are about $10 \mathrm{~mm}$ in length.
45. Ipomoea megapotamica Choisy (1845: 375). Type: "Uruguay" (possibly South Brazil fide O'Donell 1948: 182), Otto s.n. (syntype B, not found, presumably destroyed in 1943), neotype: Brazil, Mato Grosso do Sul, Terrenos, G. Hatschbach 23711 (NY0101991, designated here, isoneotypes F, MBM).

Ipomoea subalata Hassl. (Hassler 1911: 157), synon. nov.

Type: Paraguay, San Luis, K. Fiebrig 4485 p.p. (holotype G00175183, isotype G00175182).

Twining perennial herb reaching $2 \mathrm{~m}$, stems thinly pubescent to subglabrous. Leaves petiolate, $4-10 \times 4-$ $10 \mathrm{~cm}$, broadly ovate, cordate, acute and apiculate, minutely scabridulous to thinly appressed pubescent on both surfaces, abaxially paler, often dark gland-dotted; petioles $2.5-5 \mathrm{~cm}$. Inflorescence of long pedunculate, manyflowered, lax, compound cymes; peduncles $2.5-20 \mathrm{~cm}$, glabrous to puberulent; bracteoles linear, $3-4 \mathrm{~mm}$, caducous; secondary peduncles $1-5.5 \mathrm{~cm}$; tertiary peduncles $1-1.5 \mathrm{~cm}$; quaternary peduncles $0.5-1 \mathrm{~cm}$; pedicels $3-5 \mathrm{~mm}$ long, puberulent; sepals $6-7 \mathrm{~mm}$, ovate, acute, the apex erect (slightly bent backwards), concave, tomentellous, often dotted with dark glands; corolla $4.5-6 \mathrm{~cm}$, pale pink with a darker centre, pubescent, funnel-shaped, limb 3-4 cm diam., unlobed. Capsule glabrous, style persistent in fruit; seeds not seen.

TYPIFICATION. Choisy cited two collections following the description, Otto s.n. from Uruguay and Lund s.n. from San Carlos in Brazil. The Otto collection is missing and was probably destroyed in Berlin in 1943. The Lund specimen is still extant at Geneva (G00135880) but it cannot be treated as a syntype nor should it be selected as a lectotype as Choisy expressly treated it as resembling but differing from the type collection mentioning specifically its nondichotomous branching and shorter, glabrous sepals, annotating it "affin. Ip. Megapotamica Chois." In order to fix the identity of this species we are designating Hatschbach 23711 (NY) as a neotype. This coincides with the current interpretation of this species in Brazil and shows the rather distinctive dichotomous (actually cymose) branching to which Choisy referred.

DISTRIBUTION \& HABITAT. Found around the north and east of the Chaco in Bolivia, Paraguay and Brazil and, like a number of Chaco species, also present in NE Brazil. In Bolivia it has been mostly found at low altitudes along the line of the new road from Santa Cruz to Brazil and was notably more common immediately following its construction but became less common in subsequent years.

SPECIMENS eXAMINed. BoliviA. Santa Cruz: Prov. Chiquitos, village of San José de Chiquitos, $17^{\circ} 50^{\prime} 07^{\prime \prime S}$ 6044'19"W, 294 m, 1 March 2007, J. R. I. Wood et al. 22862 (HSB, K, LPB, USZ); entre San José y Taperas, 1802'27"S, 60²4'38"W, 498 m, 6 March 2011, J. R. I. Wood E D. Soto 27172 (K, LPB, USZ). Prov. Germán 
Busch, $4 \mathrm{~km}$ de Puerto Suárez en el camino a Cerro Mutún, 1901'56"S 5749'38"W, 219 m, 23 Nov. 2008, J. R. I .Wood E D. Villarroel 25516 (K, LPB, UB, USZ); $1 \mathrm{~km}$ al E de Candelaria sobre la carretera a Puerto Suárez, 18³7'34"S 58 59'01"W, 171 m, 19 March 2011, J. R. I. Wood et al. 27231 (K, LPB, USZ); 3 km del Portón de la Misión del Rincón del Tigre sobre el camino a Carmen Rivero Tórrez, 18¹3'27"S 58¹2'40"W, 222 m, 21 March 2011, J. R. I. Wood et al. 27269 (K, LPB, USZ). Tarija: Prov. Gran Chaco, $2.2 \mathrm{~km}$ from Palos Blancos to Villamontes, $21^{\circ} 25^{\prime} 05^{\prime \prime} \mathrm{S} 63^{\circ} 45^{\prime} 49^{\prime \prime} \mathrm{W}, 734$ m, 17 Feb. 2008, M. Mendoza et al. 2899 (K, USZ); 5 - $8 \mathrm{~km}$ antes de llegar a Palos Blancos sobre el camino Villamontes-Palos Blancos, 21 25'20"S 634' $53^{\circ} \mathrm{W}, 772 \mathrm{~m}, 24$ March 2013, J. R. I. Wood et al. 27617 (LPB, OXF, USZ).

CONSERVATION STATUS. Least Concern (LC).

PHENOLOGY. It has been found in flower mostly in March and seems to stop flowering somewhat abruptly after the end of the rains.

NOTES. Differs from Ipomoea hieronymi in the shorter sepals, sparsely pubescent leaves and distinctly dichotomously branched, compound inflorescences. The sepals, pedicels and, sometimes, the leaves are glanddotted. This species is also close to I. opulifolia but it is almost always easily distinguished by the entire (rarely very shallowly lobed) leaves which are relatively small and sparsely pubescent beneath.

Ipomoea subalata is a synonym of I. megapotamica. The type collection (Fiebrig 4485) is mixed as noted by Hassler (1911: 157). Only two sheets G00175183 and G00175182 belong to I. subalata. Of these the former constitutes the holotype as it originates from Hassler's personal herbarium, which is specified as the depository of the type. The latter is an isotype, even though the word "TYPUS" on a red label is affixed to the sheet in Geneva.

46. Ipomoea opulifolia Rusby (1899: 150). Type: Bolivia, H. H. Rusby 1999 (holotype NY).

Vigorous species $3-4 \mathrm{~m}$ high, stems relatively stout, adpressed pilose. Leaves petiolate, $5-14 \times 4-16 \mathrm{~cm}$, 3lobed, cut to about half way, apex shortly acuminate and mucronate, base broadly cuneate to subtruncate with rounded auricles, central lobe slightly narrowed to base, adaxially punctate with hair bases and scattered hairs, abaxially softly adpressed silvery-grey pilose, usually gland-dotted; petioles $2-11 \mathrm{~cm}$, pubescent. Inflorescence of lax pedunculate, axillary cymes; peduncles $2-10 \mathrm{~cm}$, densely pubescent; bracteoles $2 \mathrm{~mm}$, scale-like, silverypilose, caducous; secondary peduncles $1.5 \mathrm{~cm}$; pedicels 7 - $8 \mathrm{~mm}$, densely silvery-pilose; sepals slightly unequal, sericeous, outer $10-11 \times 4-6 \mathrm{~mm}$, ovate, acute, greysericeous, the inner sepals c. $6 \mathrm{~mm}$ wide. oblong-elliptic, rounded to truncate, the margin scarious and glabrous; corolla $7-8 \mathrm{~cm}$ long, funnel-shaped, mauve, sericeous, limb c. $4 \mathrm{~cm}$ diam. Capsule and seeds not known.
DISTRIBUTION \& HABITAT. Endemic to Bolivia. This is a species of moist forest and forest relics in the Andean foothills below $700 \mathrm{~m}$ from Alto Madidi near the Peruvian border south to the Chapare region. Its occurrence in Peru might be expected. Map 15.

SPECIMENS EXAMINED. BOLIVIA. Beni: Prov. Ballivian, Espiritu, 200 m, 13 April 1981, S. G. Beck 5371 (FTG, LPB); Est Biol. de Beni, $40 \mathrm{~km}$ E of San Borja, 14 $50^{\prime} \mathrm{S}$ 66 40 'W, 200 m, 16 April 1991, T. J. Killeen 2836 (MO, USZ); ibid., $14^{\circ} 30^{\prime} \mathrm{S} 66^{\circ} 37^{\prime} \mathrm{W}, 200 \mathrm{~m}, 25$ April 1995, E. Rivero 357 (ARIZ, LPB); c. $10 \mathrm{~km} \mathrm{E} \mathrm{of} \mathrm{Quiquibey}$ bridge on road from Caranavi to Yacumo, $600 \mathrm{~m}, 23$ April 2000, J. R. I. Wood 16278 (HSB, K, LPB, USZ). Prov. Yacuma, Est. Biologica del Beni, Estancia el Porvenir, 14³0'S 66 30'W, 190 m, 26 April 1995, E. Gutiérrez et al. 1567 (FTG, MO, USZ). Beni/La Paz: Río Beni, above Rurrenabague, $14^{\circ} 35^{\prime} \mathrm{S} 67^{\circ} 35^{\prime} \mathrm{W}, 320$ m, 12 May 1990, D. Daly et al. 6418 (FTG, USZ). Cochabamba: Prov. Chapare, Territorio Indigena Parque Nacional IsiboroSécure, Com. San Antonio, 16 202'S 655' W, 240 m, 17 April 2004, E. Thomas 699 (BOLV, K, LPB). La Paz: Prov. Iturralde, Alto Madidi, 68 $46^{\prime} \mathrm{S} 13^{\circ} 35^{\prime} \mathrm{W}, 370 \mathrm{~m}, 26$ May 1990, A. Gentry E S. Estensoro 70653 (LPB, MO, $\mathrm{SP})$; Com. Buenavista, $14^{\circ} 22^{\prime} \mathrm{S} 67^{\circ} 33^{\prime} \mathrm{W}, 180 \mathrm{~m}, 8$ May 1995, De Walt E Serrato 370/74 (LPB, MO); PN Madidi, Río Eslabón, 14 24'S 6757'W, 450 m, 22 April 1997, A. Paniagua 1107 (ARIZ, MO); San Buenaventura, $14^{\circ} 26^{\prime} 20^{\prime \prime S} 67^{\circ} 32^{\prime} 11^{\prime \prime} \mathrm{W}, 190$ m, 13 April 2002, A. Fuentes 4387 (BOLV, LPB, MO, USZ); $6 \mathrm{~km}$ de Ixiamas hacia Rurrenabague, $13^{\circ} 49^{\prime} 20^{\prime \prime} \mathrm{W} 68^{\circ} 04^{\prime} 01^{\prime \prime} \mathrm{W}, 258 \mathrm{~m}, 13$ May 2008, M. Mendoza et al. 3150 (K, USZ). Prov. Larecaja, Guanai, c. 700 m, May 1886, H. Rusby 1999 (MICH, NY).

CONSERVATION STATUS. This species should be provisionally classified as Least Concern (LC) as its extent of occupancy exceeds 48,765 $\mathrm{km}^{2}$. However little information is available about the size of individual populations or the effect of forest clearance so this may need revision when further information becomes available. PHENOLOGY. All collections have been made in April and May at the end of the rainy season.

NOTES. This species is morphologically close to Ipomoea megapotamica differing in the acutely 3-lobed leaves and the silvery-grey appressed pilose abaxial surface of the leaves.

47. Ipomoea spinulifera $J . R$. I. Wood $\mathcal{E} R$. W. Scotland, sp. nov. Type: Bolivia, Tarija, Prov. O'Connor, on descent from Caneletas to Narvaez, on road from Tarija to Entre Rios, J. R. I. Wood 27923 (holotype LPB; isotypes $\mathrm{K}, \mathrm{LPB}, \mathrm{OXF}$ ).

http:/ /www.ipni.org/urn:lsid:ipni.org:names:77148126-1

Very vigorous liana-like perennial to $5 \mathrm{~m}$; stems relatively stout, thinly pilose with long white hairs, spinulose 
with short triangular spines on angles. Leaves petiolate, $9-11 \times 8-10 \mathrm{~cm}$, ovate, base cordate with rounded auricles, apex acute to shortly mucronate, margin entire, adaxially green, glabrous, abaxially paler, veins pilose and highlighted with whitish hairs, intercostal regions glabrous; petioles $5-9 \mathrm{~cm}$, thinly pilose. Inflorescence of long-pedunculate, lax, compound cymes comprising 5 - 10 flowers; primary peduncles very long, $17-21 \mathrm{~cm}$, thinly pilose and with a few scattered stalked glands and spinules; secondary peduncles $3-3.5 \mathrm{~cm}$, pilose; tertiary peduncles $2-3 \mathrm{~cm}$; bracteoles $1.5 \times$ $0.5 \mathrm{~mm}$, oblong, caducous; pedicels $12-23 \mathrm{~mm}$, densely white-pilose, bearded below flower; outer sepals $10-11 \times 7 \mathrm{~mm}$, ovate, obtuse to retuse, dark green when fresh, pubescent at centre near base, glabrous upwards and at margins, the scarious margins thin; inner sepals $10-11 \times 8 \mathrm{~mm}$, broadly elliptic, glabrous except near base, scarious margins broad; corolla $7.5-9 \mathrm{~cm}$ long, gradually widened from base, pink, in bud pubescent, limb c. $5 \mathrm{~cm}$ wide, undulate to weakly lobed; stamens included, filaments unequal, glabrous apart from the pubescent basal expanded part, shorter filaments $16-17 \mathrm{~mm}$, longer 22 - $23 \mathrm{~mm}$; anthers linear, $5 \times 0.5 \mathrm{~mm}$; style 3.2 $\mathrm{cm}$, glabrous, ovary glabrous. Capsule and seeds not seen. Figs 13E, 16.

RECOGNITION. Ipomoea spinulifera clearly belongs to the radiation of species centred on the Chaco and appears to be related to I. hieronymi (Kuntze) O'Donell but is distinguished by the dark green, near glabrous sepals, very large corolla $7.5-9 \mathrm{~cm}$ long and spinulose stems.

DISTRIBUTION \& HABITAT. Appears to be endemic to the Narvaez region of O'Connor Province in Tarija, where it is locally common. It grows in scrub and forest relics derived from former moist Tucuman-Bolivian forest.

SPECIMEnS EXAMINED. BOliviA. Tarija: Prov. Arce, Padcaya, Camp. Los Pinos, PN Tariquia, 21 55'13"S 642ㄴ'50"W, 1600 m, 6 March 2005, M. Serrano et al. 6038 (ARIZ, MO). Prov. O’Connor, Com. Narvaez, $21^{\circ} 24^{\prime} 59^{\prime \prime S}, 64^{\circ} 16^{\prime} 57^{\prime \prime W}, 1822 \mathrm{~m}, 15$ Jan. 2008, J. Villalobos et al. 1307 (HSB, MO, OXF); on descent from Caneletas to Narvaez, on road from Tarija to Entre Rios, $21^{\circ} 26^{\prime} \mathrm{S} 64^{\circ} 18^{\prime} \mathrm{W}, 2100 \mathrm{~m}, 3$ Feb. 2014, J. $R$. I. Wood 27923 (K, LPB, USZ); Narvaez valley, between Tarija and Entre Rios, 21 ${ }^{\circ} 27^{\prime} \mathrm{S} 64^{\circ} 17^{\prime} \mathrm{W}, 2000 \mathrm{~m}, 3$ Feb. 2014, J. R. I. Wood 27924 (K, LPB, OXF, USZ).

CONSERVATION STATUS. Data Deficient (DD). This species has not been carefully studied in the field but it does appear to be restricted to the area around Narvaez in the south of Bolivia. It is almost certainly threatened in some way because of the very local distribution of its known populations. Unless extensive populations are found away from the roadsides where it is currently known a categorisation of Critically endangered (CR) may be necessary.
PHENOLOGY. It has been collected in January and February.

ETYMOLOGY. The epithet "spinulifera" refers to the small spines present on the mature stems, these being an unusual feature in Ipomoea.

NOTES. M. A. Negritto et al. 502 (MA, CORD, n.v.) from an unspecified location in Prov. Arce in Tarija Department appears to be intermediate between this species and Ipomoea jujuyensis. It was identified by the collectors as I. lilloana to which it would key following O'Donell's (1959b) key to Argentinian species of Ipomoea because of the pubescent midpetaline bands which are clearly visible on the buds but it is not I. lilloana. The somewhat truncate calyx and large corolla suggests an affinity with I. spinulifera but the leaves are very thinly pubescent and the pedicels glabrous. More collections are needed to clarify its status.

48. Ipomoea gypsophila $J$. R. I. Wood $\mathcal{E}^{2} R$. W. Scotland, sp. nov. Type: Bolivia, Tarija, Prov. Aniceto Arce Ruiz, La Merced, $30 \mathrm{~km}$ de Padcaya hacia Bermejo, S. G. Beck, R. Kiesling E D. Metzing 22139 (holotype LPB; isotypes SI n.v., K (leaves only)).

http://www.ipni.org/urn:Isid:ipni.org:names:77148127-1

Stout trailing or weakly ascending plant, stems lanate. Leaves petiolate, $7-10 \times 6-10 \mathrm{~cm}$, ovate, base cordate with rounded overlapping auricles, apex acute, adaxially appressed white-villous, abaxially densely white lanatetomentose, petiole $3-6 \mathrm{~cm}$. Flowers $1(-3)$ in pedunculate, axillary cymes; peduncles $5-7 \mathrm{~cm}$, lanate, straight or nearly so, bracteoles $2-3 \mathrm{~mm}$, lanceolate, somewhat persistent; pedicels $8 \mathrm{~mm}$; sepals subequal, $15 \times 5 \mathrm{~mm}$, oblong-lanceolate to oblong-ovate, obtuse, lanate; corolla $7-8 \mathrm{~cm}$, funnel-shaped, uniformly pink, tomentose at base and on midpetaline bands, limb c. $5 \mathrm{~cm}$ diam. Capsule and seeds not seen. Fig. 17.

RECOGNITION. This species bears a superficial resemblance to Ipomoea descolei O'Donell from Corrientes and Misiones in Argentina but is Andean in distribution and immediately distinguished by the indumentum of the corolla, sepals, stem and peduncles which is appressed, not spreading. The leaves are not strongly reticulate beneath, are white on both surfaces (not dark green above) whereas the flowers are usually solitary (cymes not 2-8-flowered), and the peduncles shorter reaching only $7 \mathrm{~cm}$ (not $5-20 \mathrm{~cm}$ as in I. descolei). Amongst species known from Bolivia it is quite distinct.

DISTRIBUTION \& HABITAT. Endemic to Bolivia, occurring only in Tarija Department. It is a plant of open rocky slopes.

SPECIMENS EXAMINED. BOLIVIA. Tarija: Prov. Aniceto Arce Ruiz, La Merced, $30 \mathrm{~km}$ de Padcaya hacia 


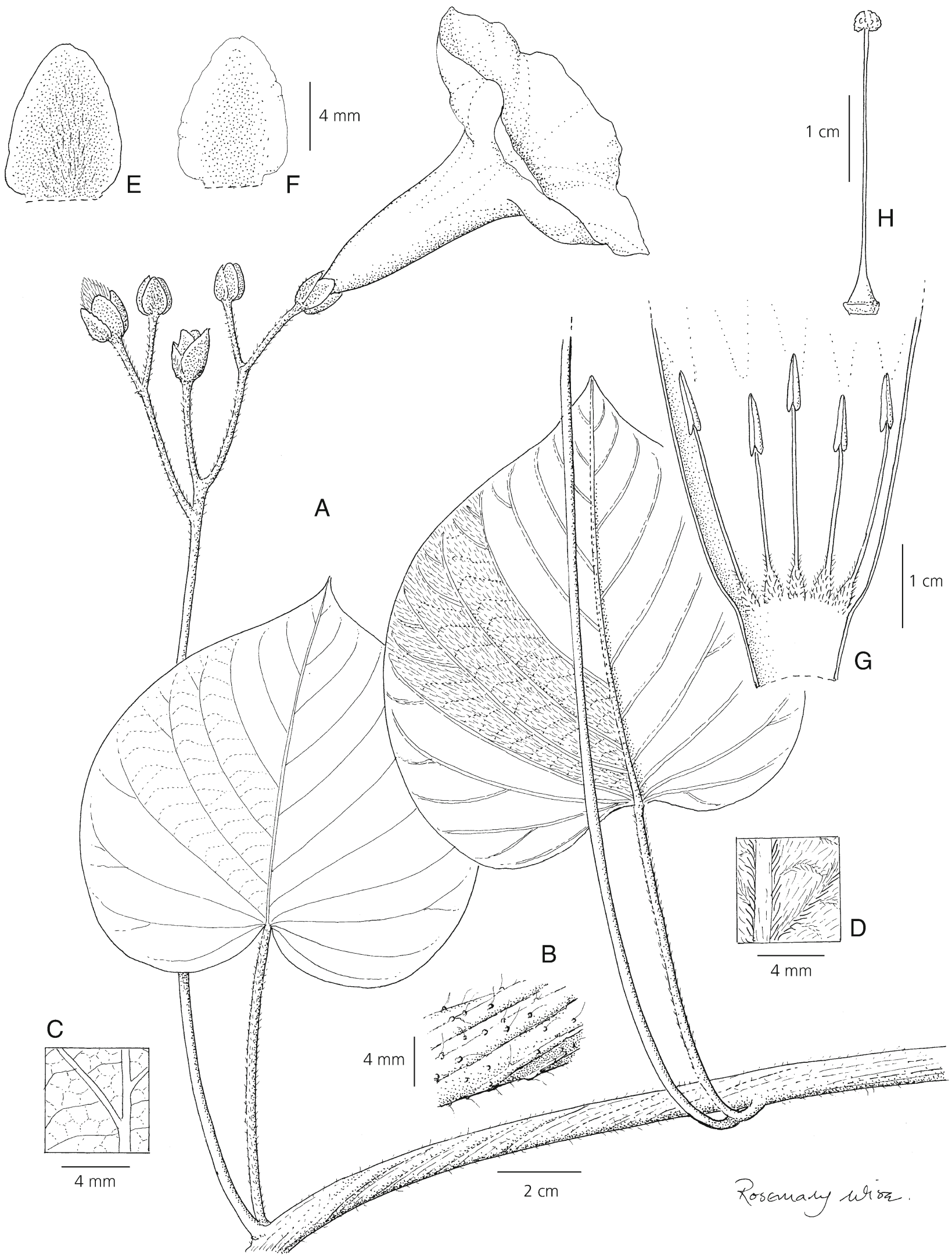

Fig. 16. Ipomoea spinulifera. A habit; B section of stem showing spinules; C adaxial leaf surface; D abaxial leaf surface; E outer sepal; F inner sepal; G corolla opened out to show stamens; H ovary and style. A - B from Villalobos et al. 1307; C - H from Wood 27923. DRAWN BY ROSEMARY WISE. 

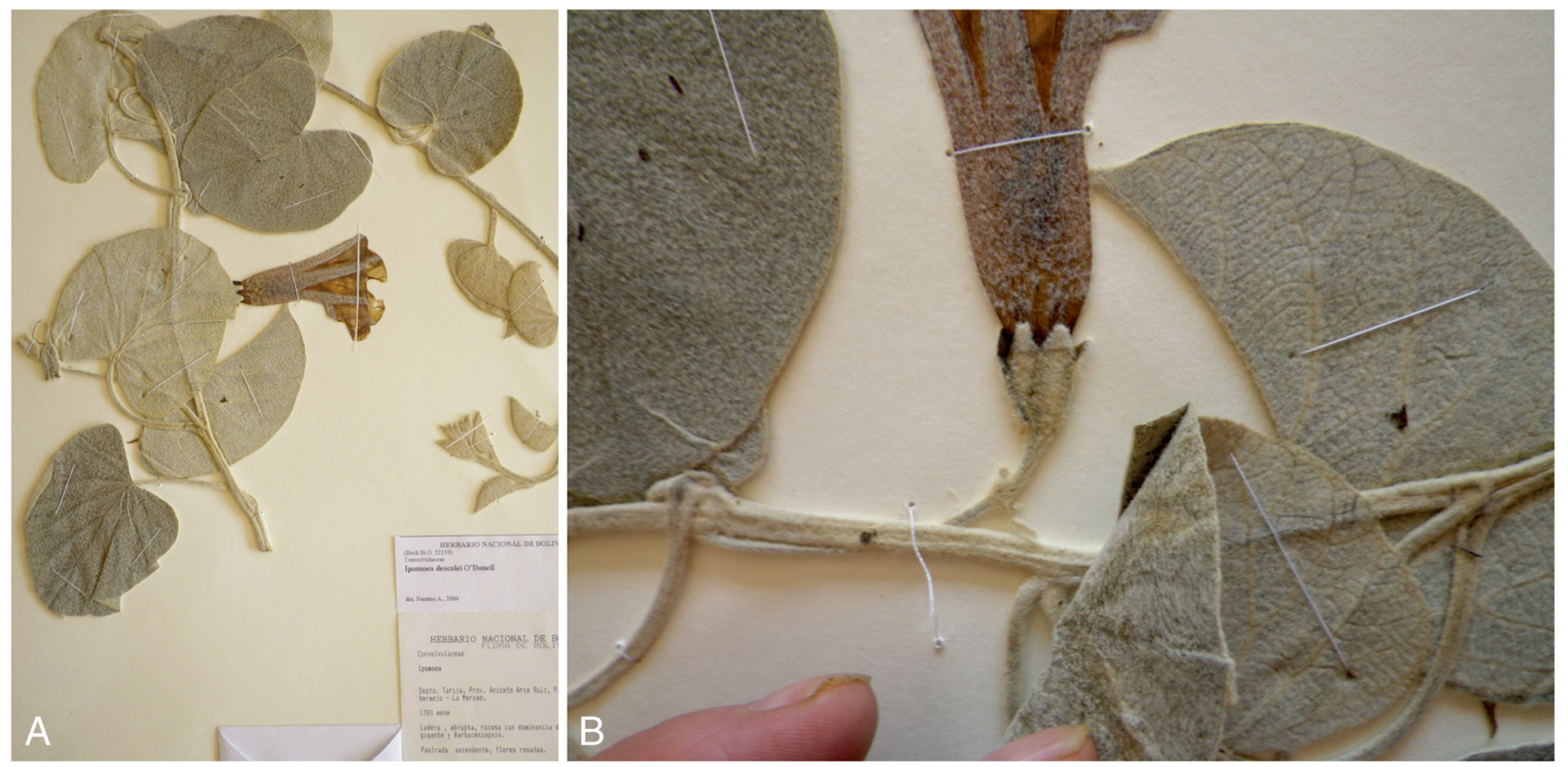

Fig. 17. Ipomoea gypsophila herbarium specimen (Beck et al. 22139) A habit; B close up showing characteristic indumentum and sepals.

Bermejo, 1700 m, 13 Nov. 1993, S. G. Beck et al. 22139 (LPB, OXF, SI). Prov. Cercado, Yesera, 2300 m, 28 Jan. 1953, T. Meyer 17334 (LIL); ibid., T. Meyer 17981 (LIL), cerca Yesera, 2050 m, 15 Jan. 1986, E. Bastian 416 (LPB).

CONSERVATION Status. Data Deficient (DD). This species is clearly very rare and might be considered to be Critically Endangered (CR) based on its extent of occurrence. However we have no information about population sizes and Yesera is an imprecise area and the three collections from this location may represent three populations or the same population. While this species is clearly endangered in a general sense, it is impossible to categorise the threat precisely without more information. PHENOLOGY. Found in flower at the onset of the rainy season in early summer from November to January.

ETYMOLOGY. The epithet gypsophila is based on the location, Yesera, where three of the four collections were made. Whether or not this species favours places with high levels of gypsum (yeso) is not known.

49. Ipomoea calyptrata Dammer (1897: 40). Type: Brazil, Minas Gerais, near Arrasnaby, Glaziou 15265 (holotype $\mathrm{B} \uparrow$, isotypes K000612835, P03878984, R).

Vigorous liana-like climber reaching $5 \mathrm{~m}$, stems woody, subtomentose. Leaves petiolate, large, $4-16 \times 5-14 \mathrm{~cm}$, ovate to subreniform, apex rounded or retuse, mucronulate, base shallowly cordate to subtruncate, margin slightly undulate. adaxially grey-tomentellous, abaxially white tomentose with conspicuous venation; petioles $1.5-5 \mathrm{~cm}$, tomentose. Inflorescence of fewflowered pedunculate, axillary cymes; peduncles 3 -
$5 \mathrm{~cm}$, tomentose; bracteoles $20 \times 4 \mathrm{~mm}$, oblanceolate, abaxially grey-tomentose, adpressed to calyx; secondary peduncles $10-15 \mathrm{~mm}$; pedicels $2-7 \mathrm{~mm}$, tomentose; sepals subequal, $1.4-2.2 \times 0.8-1.4 \mathrm{~cm}$, oblong-obovate, rounded, densely white tomentose; corolla $6-7 \mathrm{~cm}$ long, pink, funnel-shaped, densely sericeous, limb $7 \mathrm{~cm}$ diam., unlobed. Capsule $2 \times 1.5 \mathrm{~cm}$, ovoid, glabrous; seeds pilose with long white hairs. Fig. 13B.

DISTRIBUTION \& HABITAT. A rare plant of Brazil and Bolivia. In Bolivia it is characteristic of very dry forest between 1400 and $2000 \mathrm{~m}$ on the slopes of the Río Grande and its tributaries. Although large and conspicuous, there are few collections and it is clearly rare with a very restricted distribution.

SPeCIMEnS eXAmined. BoliviA. Chuquisaca: Prov. Belisario Boeto, c. $10 \mathrm{~km}$ bajando de Nuevo Mundo hacia Río Grande, 1855'59"S 64²16'53"W, 1555 m, 23 March 2004, J. R. I. Wood et al. 20496 (BOLV, HSB, K, LPB); camino entre Villa Serrano y Río Grande, 18 56'16"S 64¹6'49"W, 1603 m, 27 March 2013, J. R. I. Wood et al. 27659 (K, LPB, OXF, USZ). Santa Cruz: Prov. Caballero, Saipina, Est. Buena Vista. $18^{\circ} 03^{\prime} 18^{\prime \prime S}$ 64³9'44"W, 2000 m, 18 Feb. 1995, J. Balcazar 354 (LPB, MO, OXF, USZ). Prov. Florida, dirt road from Mairana to Alto Mairana, $18^{\circ} 08^{\prime} \mathrm{S} 64^{\circ} 00^{\prime} 30^{\prime \prime} \mathrm{W}, 1475 \mathrm{~m}$, 8 May 1998, M. Nee 49257 (NY, USZ); Alto Mairana, un poco arriba de la Com. Todos Santos, $18^{\circ} 07^{\prime} 52^{\prime \prime S}$ 6400'14"W, 1417 m, 23 Jan. 2005, J. R. I. Wood et al. 21446 (K, LPB, USZ). Prov. Vallegrande, bajando de Pucará a Santa Rosa en el Río Grande, 1841'37"S 64 $15^{\prime} 41^{\prime \prime W}, 1745 \mathrm{~m}, 25$ Jan. 2006, J. R. I.Wood E $M$. Mendoza 21472 (K, LPB, USZ); ibid., 1841'41"S 
64 16'07"W, 1759 m, 27 March 2013, J. R. I. Wood et al. 27668 (K, LPB, USZ).

CONSERVATION STATUS. Within Bolivia using Geocat this species comes out as Endangered (EN) in terms of its extent of occurrence at $3500 \mathrm{~km}^{2}$. There are only four distinct populations and none of these is large and as its liana habit suggests it is dependent on the existence of mature dry forest it faces a very real threat within Bolivia from the removal of large trees. Clearly other populations may be found as the areas which it favours are not easily accessible for botanical exploration but these are not likely to be numerous or large. We have no information about populations in Brazil but it is rare there.

PHENOLOGY. Flowers from January to May during the rainy season.

NOTES. A very distinctive species because of its liana habit, persistent bracteoles appressed to the calyx, large tomentellous sepals and pink flowers. The whole plant is subtomentose with whitish hairs.

50. Ipomoea carnea Jacq. (Jacquin 1760: 13). Type: Jacquin, Stirp. Amer. Hort. Pl. t. 18 (1763), lectotype designated by Austin (1977: 237).

Erect (subsp. fistulosa) or climbing (subsp. carnea) undershrub to $4 \mathrm{~m}$, often growing in clumps, stems stout, hollow, canescent when young, becoming glabrous. Leaves petiolate, $8-20(-30) \times 3-10(-12) \mathrm{cm}$, ovate or elongateovate-deltoid, base cordate to subtruncate with rounded auricles, apex acuminate to long-acuminate, both surfaces canescent when young, glabrescent, veins prominent abaxially; petioles $3-8 \mathrm{~cm}$. Inflorescence of longpedunculate axillary, somewhat compact cymes; peduncles 2-12 cm; bracteoles $3-4 \mathrm{~mm}$, ovate or elliptic, caducous; secondary peduncles $3-7 \mathrm{~mm}$; pedicels $5-15$ $\mathrm{mm}$, puberulent; sepals subequal, $5-6 \times 7-8 \mathrm{~mm}$, ovate to suborbicular, rounded, tomentellous, margins scarious; corolla $6-7 \mathrm{~cm}$, funnel-shaped, pink, tomentellous in bud, \pm glabrescent, limb $4.5-5 \mathrm{~cm}$ diam., shallowly lobed. Capsule $18 \times 10 \mathrm{~mm}$, ellipsoid, glabrous; seeds $10-11 \times 3-$ $4 \mathrm{~mm}$, woolly with very long hairs.

Two subspecies are widely recognised:

subsp. carnea

This is characterised by its climbing habit and ovate, shortly acuminate leaves.

It is recorded as present in Bolivia by Austin \& Huáman (1996: 6) but no specimen has been traced and the record was presumably based on erroneous information.

subsp. fistulosa (Mart. ex Choisy) D. F. Austin (1977: 237). Ipomoea fistulosa Mart. ex Choisy (1845: 349). Type: Brazil, C. F. Martius 2398 (lectotype M, designated by D. F. Austin 1977: 237).
This is characterised by its erect habit and elongate, long-acuminate leaves.

DISTRIBUTION \& HABITAT. Very common in open swamp and also fairly frequent on roadsides and in ditches in the tropical lowlands of eastern Bolivia but absent from forested regions and not recorded from Pando or the Chapare. It is also widely cultivated as an ornamental plant in gardens up to at least $1000 \mathrm{~m}$ and it is not always easy to decide whether a population is spontaneous or planted. It seems incontrovertible that it is native in swamp where it sometimes very abundant.

SELECTED SPECIMENS OF 62 EXAMINED. BOLIVIA, Beni: Prov. Ballivian, Espiritu, 13 April 1981, S. G. Beck 5348 (LPB). Prov. Cercado, Laguna Suárez, 1452'S, 645' $\mathrm{\circ}$, $160 \mathrm{~m}, 18$ June 1996, N. Ritter $\mathcal{E}^{\circ}$ M. Ritter 3335 (BOLV, MO). Prov. Iténez, El Cairo, $13^{\circ} 44^{\prime} \mathrm{S}$ $63^{\circ} 42^{\prime} \mathrm{W}, 150$ m, 7 July 2005, C. Chumacero 667 (LPB). Prov. Mamoré, $104 \mathrm{~km}$ N of Trinidad en camino a San Joaquin, 200 m, 5 Nov. 1993, M. Moraes et al. 1523 (LPB, USZ). Prov. Moxos, PN Isiboro Sécure (TIPNIS), Com. San José de Patrocinio, $15^{\circ} 27^{\prime} \mathrm{S}$ 65으'W, 200 m, 30 Jan. 1996, E. Gutiérrez et al. 1861 (BOLV). Santa Gruz: Prov. Germán Busch, Puerto Busch, 2005'55"S 5804'01"W, 122 m, 11 May 1997, M. Toledo et al. 591 (USZ). Prov. Cordillera, Laguna Camatindi, $11.5 \mathrm{~km} \mathrm{~N}$ of Boyube on dirt road to Charagua, 20²1'56"S 63¹6'37"W, 800 m, 17 April 2007, M. Nee Eं S. R. Hill 55090 (LPB, MO, NY, USZ). Prov. Ibañez Barrio Los Cusis, Santa Cruz, $17^{\circ} 45^{\prime} \mathrm{S}$ $63^{\circ} 05^{\prime} \mathrm{W}, 380 \mathrm{~m}, 12$ Oct. 1996, M. Saldias E $Y$. Roca 4932 (NY, USZ). Prov. Ichilo, Yapacani, 1892, O. Kuntze s.n. (NY). Prov. Nuflo de Chávez, c. $5 \mathrm{~km} \mathrm{~S}$ of San Ramón along the road to San Julian, $16^{\circ} 04^{\prime} 34^{\prime \prime S}$ 62 42'43"W, 265 m, 23 April, 2004, J. R. I. Wood Eं $H$. Huaylla 20803 (HSB, K, LPB, USZ). Prov. Ángel Sandoval, Laguna La Gaiba, $17^{\circ} 49^{\prime} \mathrm{S} 57^{\circ} 42^{\prime} \mathrm{W}, 90 \mathrm{~m}$, 14 July 1998, N. Ritter et al. 4531 (BOLV, MO, USZ). Prov. Santieseban, c. $5 \mathrm{~km}$ al oeste de Portachuelo en

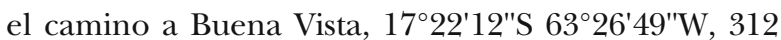
m, 4 April 2013, J. R. I. Wood E B. Williams 27736 (LPB, OXF, USZ). Prov. Velasco, PNNKM, Bahia Toledo, 14²' $53^{\prime}$ "S 61 07'32"W, 210 m, 7 Sept. 1995, N. Ritter E P. F. Foster 2391 (MO, USZ). Prov. Warnes $13 \mathrm{~km}$ NE of Warnes on road to La Esperanza, $17^{\circ} 25^{\prime} \mathrm{S}$ $63^{\circ} 04^{\prime} \mathrm{W}, 300 \mathrm{~m}, 11$ July 1994, M. Nee 45170 (LPB, MO, NY, USZ).

Apart from the Kuntze collection there are no records from Chiquitos, Guarayos, Ichilo and Santiestaban Provinces, although this species must be common in all four provinces.

CONSERVATION STATUS. Least concern (LC).

PHENOLOGY. It has been found in flower throughout the year.

NOTES. Immediately recognised by the tall erect habit combined with the cordate leaves. The sepals are unexpectedly small. 
51. Ipomoea reticulata O'Donell (1953: 389). Type: Colombia, Norte de Santander, J. Cuatrecasas 13321 (holotype LIL!, isotype F).

Ipomoea peredoi O’Donell (1960: 44), synon. nov. Type: Bolivia, Santa Cruz, I. Peredo s.n. (holotype LIL 158045 !).

Weak liana to $3 \mathrm{~m}$, stems woody, glabrous to minutely scabridulous, dotted with black glands. Leaves petiolate, $4-9 \times 3-6 \mathrm{~cm}$, ovate to suborbicular, cordate with rounded auricles, shortly acuminate, usually glabrous but sometimes scabridulous-puberulent, abaxially often minutely black-punctate; petioles 2.5 $5 \mathrm{~cm}$, scabridulous. Inflorescence of pedunculate axillary cymes, these often developing into a raceme or panicle like structure $5-10 \mathrm{~cm}$ long; peduncles 1 $4.5 \mathrm{~cm}$, sometimes extended into a rhachis up to $3 \mathrm{~cm}$ long; secondary peduncles $0.5-1.8 \mathrm{~cm}$ long; bracteoles scale-like, caducous; pedicels very variable in length. 5 $15 \mathrm{~mm}$ long, glabrous; sepals subequal, $5-7 \times 3-5 \mathrm{~mm}$, elliptic, obtuse, scarious-margined, inner obovate with very broad scarious margins; corolla $2.3-3.5 \mathrm{~cm}$, creamywhite with greenish midpetaline bands and (sometimes a dull violet centre), campanulate, glabrous, limb $2.5 \mathrm{~cm}$ diam., undulate; stamens held at corolla mouth. Capsule ovoid, $10-12 \times 7-8 \mathrm{~mm}$, glabrous; seeds $5 \mathrm{~mm}$ long, pilose. Fig. 18D.

DISTRIBUTION \& HABITAT. Widely distributed in tropical America from southern Mexico south to Bolivia and Paraguay but usually in rainforest or in moister areas of seasonally dry forest. In Bolivia it is principally a plant of the Andean foothills of the Amboró and Carrasco National Parks but is also common in Chiquitano Dry Forest. Map 12.

SELECTED SPECIMENS OF 35 EXAMINED. BOLIVIA. Beni: Prov. Ballivian, Beni, Ballivian, Est. Biologica del Beni, Com. Totaizal, 14³0'S 66³7'W, 200 m, 8 May 1995, J. Balderrama 517 (LPB, NY). Chuquisaca: Prov. Luis Calvo, Serranía del Iñao, 19³5'36"S 6353'19"W, 1530 m, 14 April 2003, A. Carretero et al. 867 (HSB, MO). Cochabamba: Prov. Carrasco, PN Carrasco, Entre Rios, Camp. Colomelin, Río Ichoa, 17²3'05"S 64³1'18"W, 340 m, 4 April 2006, O. Colque Ẽ L. Mendoza 472 (MO, OXF, USZ). Prov. Chapare, al lado del puente sobre el Río Espiritu Santo, aproximadamente $20 \mathrm{~km}$ sobre el camino Villa Tunari-Cochabamba cerca del lugar "El Chocolatal", 1959'52"S, 65³5'54"W, 486 m, 4 April 2013, J. R. I. Wood Eं B. Williams 27732 (K, LPB, USZ). La Paz: Prov. Larecaja, Guanai, 650 m, May 1886, H. H. Rusby 1995 (MICH, NY). Santa Cruz: Prov. Florida, Amboró Park, La Playa, 15 - $20 \mathrm{~km} \mathrm{~N}$ of Santa Rosa de Lima, 1746'05"S 64²13'05"W, 1300 - 1400 m, 7 - 8 April 1993, I. G. Vargas et al. 2170 (MO, NY). Prov. Guarayos, Guarayos, aserradero La Chonta, $15^{\circ} 45^{\prime} \mathrm{S} 62^{\circ} 60^{\prime} \mathrm{W}, 300 \mathrm{~m}, 25$ April 1999, M. Toledo $\mathcal{E}^{\circ}$ J. Justiniano 996 (MO, USZ). Prov. Ichilo, c. $1 \mathrm{~km}$ al este del Puente Río Ichilo, en el camino de Villa

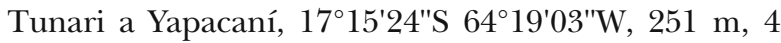
April 2013, J. R. I. Wood E B. Williams 27734 (K, LPB, OXF, USZ). Prov. Ibañez, Jardín Botánico de Santa Cruz on road to Cotoca, $17^{\circ} 47^{\prime} \mathrm{S} 63^{\circ} 04^{\prime} \mathrm{W}, 375 \mathrm{~m}, 5$ June 1998, M. Nee E L. Bohs (CTES, MO, NY, USZ). Prov. Nuflo de Chávez, c. 4 km N of San Javier on road to hot springs, $550 \mathrm{~m}$, 29 March 1999, J. R. I. Wood 14767 (K, LPB, USZ). Prov. Velasco, Asseradero Moiri, Bajo Paraguá, 1435'52"S 61 21 '11"W, 180 m, 11 May 1994, T. J. Killeen 6252 (ARIZ, MO, OXF). Tarija: Prov. Arce, at junction of road to Sidras at Com. Emboroza, 22 $16^{\prime} \mathrm{S} 64^{\circ} 33^{\prime} \mathrm{W}, 900$ m, 25 April 1983 (fr.), J. Solomon 10069 (MO).

CONSERVATION STATUS. Least Concern (LC).

PHENOLOGY. Flowers principally in April and May

NOTES. Usually easily identified by the small flattish sepals and short, campanulate, cream corolla but sometimes difficult to distinguish herbarium specimens from Ipomoea batatoides which also commonly has leaves abaxially gland-dotted. However in $I$. batatoides the corolla is much larger and usually pink and the sepals are coriaceous and concave, without broad scarious margins. It is similar in flower colour and tendency to produce raceme-like inflorescences to $I$. corymbosa but for differences with that species see under I. corymbosa.

In southern Brazil Ipomoea reticulata is largely replaced by I. saopaulista O'Donell, which differs in its larger corollas. Intermediates between the two are reported from Goiás.

52. Ipomoea tarijensis O'Donell (1960: 53). Type: Bolivia, Tarija, 1904, K. Fiebrig 2655A (holotype BM!, isotypes $\mathrm{K}$ !, $\mathrm{P}$ !).

Trailing herb, stems up to $2 \mathrm{~m}$ long, thinly pubescent. Leaves petiolate, $5-11 \times 5-11 \mathrm{~cm}$, ovate to suborbicular, narrowly cordate with rounded, overlapping auricles, apex shortly acuminate, adaxially almost glabrous, abaxially bluish-grey with prominent, raised veins, scurfy-pubescent; petioles $3-6 \mathrm{~cm}$, thinly pubescent. Inflorescence of long-pedunculate, $1-3(-5)$ flowered, axillary cymes, peduncles $7-15 \mathrm{~cm}$, straight; bracteoles caducous; secondary peduncles $0.5-1.6 \mathrm{~cm}$; pedicels $0.5-2.5 \mathrm{~cm}$, scurfy-pubescent, slightly widened below calyx, often fracturing at summit; sepals subequal, $7-9 \times 4-5 \mathrm{~mm}$, broadly oblong, obtuse, thinly scurfy-puberulent, margins scarious, glabrous, inner c. $1 \mathrm{~mm}$ longer and broader with broad scarious margins; corolla $4.5-5 \mathrm{~cm}$ long, shortly funnel-shaped being flared from just above basal tube, glabrous, pale pink, limb c. $5 \mathrm{~cm}$ in diam., distinctly lobed with rounded lobes, stamens held at corolla mouth. Capsule ovoid, $2 \mathrm{~cm}$ long, shortly rostrate, glabrous; seeds $6 \mathrm{~mm}$ long, densely lanate. Figs $18 \mathrm{~A}-\mathrm{C}$. 

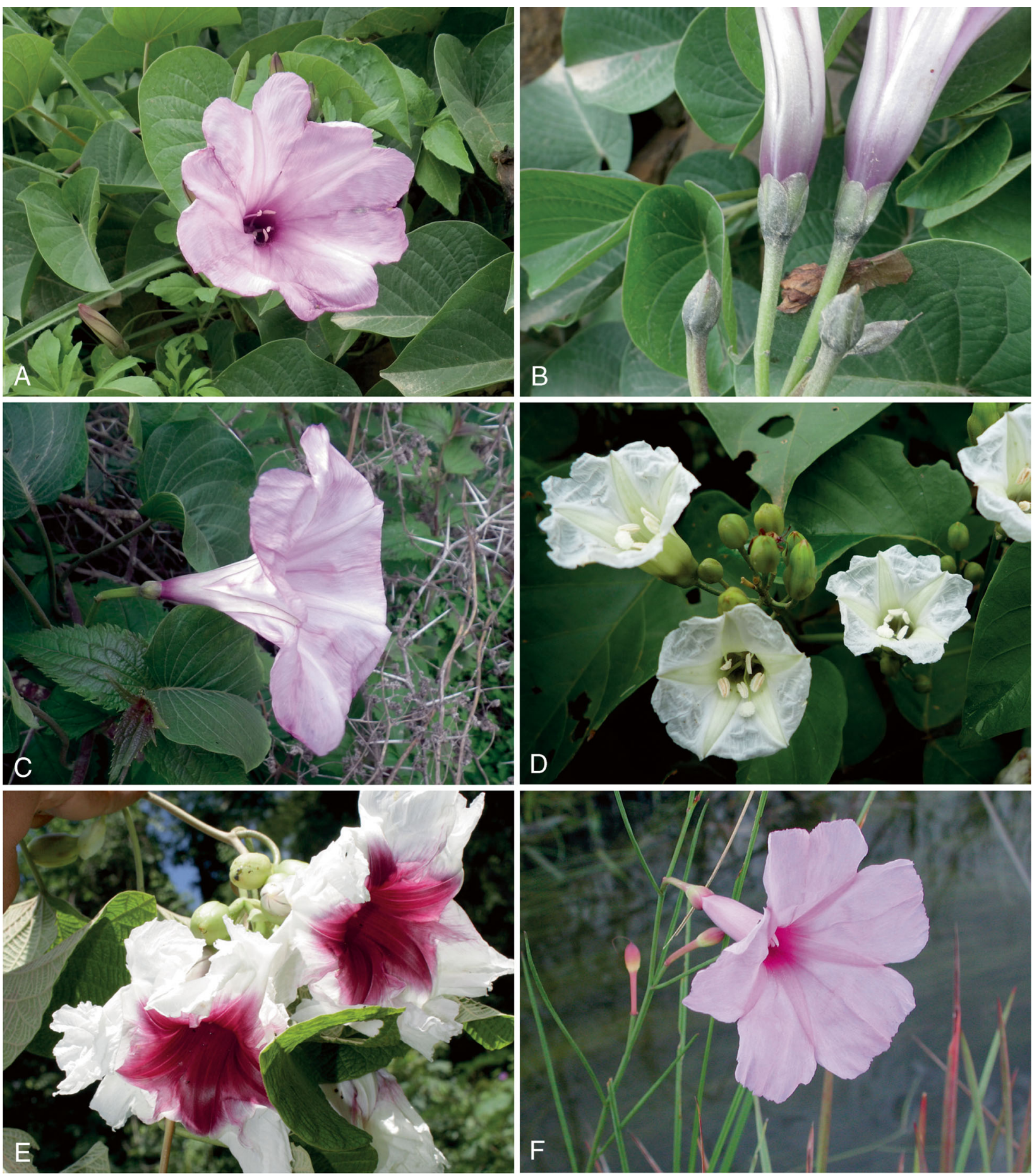

Fig. 18. A - C. Ipomoea tarijensis; D I. reticulata; E I. paradae F. I. schomburgkii. PHOTOS: A - C JOHN WOOD; D BETH WILLIAMS; E ALEXANDER PARADA; F LOUISE EMMONS.

DISTRIBUTION \& HABITAT. A Bolivian endemic with its principal population on the Cuesta del Condor on the borders of Cercado and O'Connor provinces in Tarija Department. It grows on open stony banks, in abandoned fields and in scrubby gullies around $2500 \mathrm{~m}$. Map 10 .

SPECIMENS EXAMINED. BOLIVIA. Tarija: Prov. Cercado, km 31, Tarija-Entre Rios, c. 2500 m, 19 March 1966,
W. J. Badcock 777 (K); on first, small pass c. $20 \mathrm{~km} \mathrm{E}$ of Tarija on road to Entre Rios, $2300 \mathrm{~m}, 6$ March 2000, J. R. I. Wood 15954 (K, LPB); km 34 on road from Tarija to Entre Rios (main population on Cuesta del Condor, $\mathrm{km} 43$ - 48), 21 ${ }^{\circ} 27^{\prime} \mathrm{S}$ $64^{\circ} 29^{\prime} \mathrm{W}, 2500 \mathrm{~m}, 3$ Feb. 2014, J. R. I. Wood 27920 (K, LPB, OXF, USZ). Prov. O'Connor, $46 \mathrm{~km} \mathrm{~W}$ of 


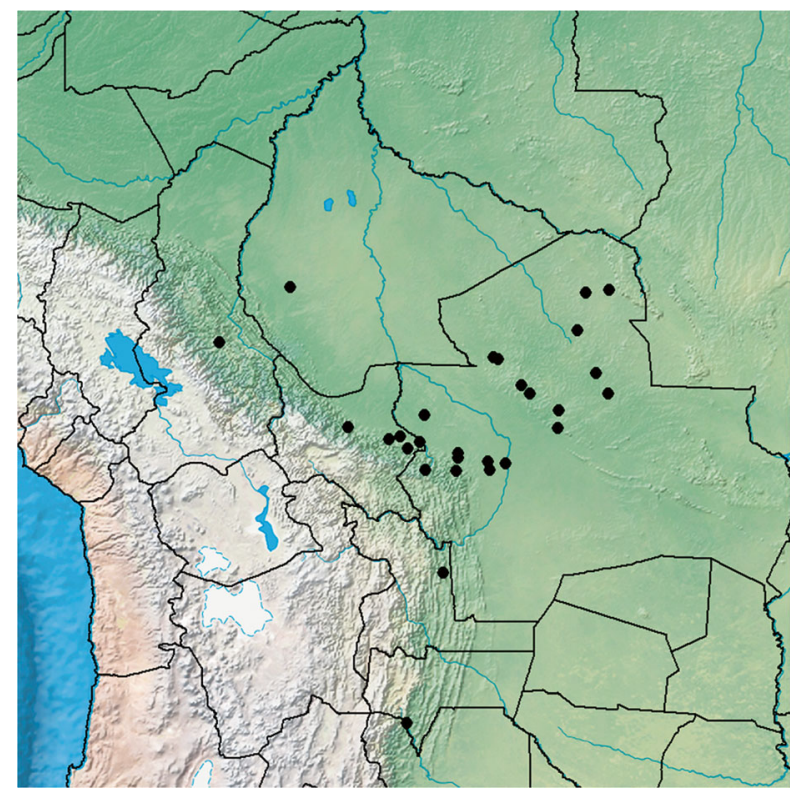

Map 12. Distribution of Ipomoea reticulata (๑), a lowland forest species most common around Santa Cruz.

Tarija hacia Palos Blancos, 2640 m, 14 Nov. 1993, S. G. Beck et al. 22202 (LPB, SI).

CONSERVATION STATUS. Although the extent of occurrence of this species suggests a classification of Critically Endangered, a provisional Endangered (EN) seems more appropriate until the populations can be properly evaluated. Although very local, Ipomoea tarijensis is quite common over several kilometres and is at home in derelict fields and scrubby gullies near the road so it seems well able to adapt to habitat change.

PHENOLOGY. Flowers after significant rain between November and March.

NOTES. O'Donell compared this species with Ipomoea jujuyensis and I. lilloana. From the latter it is easily distinguished by the glabrous buds; from the former it is less easily distinguished by the trailing habit, oblong rather than elliptic sepals, the overlapping leaf auricles, the short stamens $(2.5 \mathrm{~cm}$, not $4-5 \mathrm{~cm}$ long $)$ and the long hairs on the seeds.

The stamens of Ipomoea tarijensis are visible at the mouth of the corolla but are unusually short, a character it shares with I. reticulata. Molecular studies suggest these two and I. saopaulista form a single clade.

53. Ipomoea graniticola J. R. I. Wood $\mathcal{E} R$ R. W. Scotland, sp. nov. Type: Bolivia, Santa Cruz, Nuflo de Chávez, El Cerrito, J. R. I. Wood, D. Villarroel Ẽ S. Renvoize 25750 (holotype USZ; isotypes K, LPB, UB).

http://www.ipni.org/urn:lsid:ipni.org:names:77148128-1

Twining perennial to $2 \mathrm{~m}$, completely glabrous in all vegetative parts; stems slender. Leaves petiolate, divided into 5 separate leaflets, base \pm truncate, leaflets $1.2-3 \times 0.2$ $-0.6 \mathrm{~cm}$, attenuate at both ends, apex acute, the basal pair narrowly oblong, the remaining three narrowly oblongelliptic; petiole $1.2-1.5 \mathrm{~cm}$, commonly straight. Inflorescence of 1 - 2-flowered, axillary, pedunculate cymes, peduncles slender, $2.5-5 \mathrm{~cm}$, secondary peduncles c. $1.5 \mathrm{~cm}$; bracteoles $1.5 \times 0.5 \mathrm{~mm}$, strap-shaped, obtuse, early caducous; pedicels $1.1-2 \mathrm{~mm}$; sepals equal, $7-8 \times 3.5$ $\mathrm{mm}$, broadly oblong, rounded, margins broad, scarious; corolla $6-7 \mathrm{~cm}$, pink, glabrous, funnel-shaped, limb $5-6$ $\mathrm{cm}$, unlobed, stamens included, filaments glabrous except glandular base, shorter $7-8 \mathrm{~mm}$ long, longer very unequal, $12-18 \mathrm{~mm}$, anthers linear, $5-6 \times 1 \mathrm{~mm}$, anthers $5 \times 0.75 \mathrm{~mm}$; ovary glabrous; style $3 \mathrm{~cm}$, glabrous; stigma obscurely bilobed. Capsule $8 \times 6 \mathrm{~mm}$, obovoid, conspicuously 5-lobed, glabrous; seeds $4.5 \times 3 \mathrm{~mm}$, \pm ovoid, pale brown, with deciduous white marginal hairs c. $3 \mathrm{~mm}$ in length. Fig. 19A - H, 30C.

RECOGNITION. This species is related to Ipomoea rosea Choisy from NE Brazil differing principally in the absence of a tooth-like appendage on the abaxial surface of the sepal. It has been confused with I. subrevoluta but differs in the larger obtuse to rounded sepals and grows in a quite different habitat.

DISTRIBUTION \& HABITAT. Known from two locations, one in Bolivia, one in Brazil. In Bolivia it is found around the community of $\mathrm{El}$ Cerrito in the Lomerío region of Nuflo de Chávez Province of Santa Cruz Department. Here it is locally common and characteristic of islands of vegetation on granite rock domes where it grows amongst spiny Bromeliaceae, especially Deuterocohnia meziana Kuntze ex Mez and over small trees of Commiphora leptophoeos (Mart.) J. B. Gillett. In Brazil it is found in Mato Grosso where it is recorded as growing on quartzite rocks.

SPECIMENS eXAMined. BoliviA. Santa Gruz: Prov. Nuflo de Chávez, El Cerrito, Lomerío, 16³4'58"S 61 53 '54"W, $439 \mathrm{~m}, 31$ May 2008, J. R. I. Wood et al. 24991 (K, LPB, UB, USZ); ibid., 6³4'57"S 61 ${ }^{\circ} 49^{\prime} 54^{\prime \prime} \mathrm{W}$, 447 m, 17 March 2009, J. R. I. Wood et al. 25750 (K, LPB, UB, USZ); ibid., $16^{\circ} 35^{\prime} 38^{\prime \prime} \mathrm{S}, 61^{\circ} 52^{\prime} 54^{\prime \prime} \mathrm{W}, 451 \mathrm{~m}, 11$ April 2013, J. R. I. Wood et al. 27763 (LPB, OXF, USZ). BRAZIL.

Mato Grosso, right side of Río Juruena, S. João da Barra, on quartzite rocks, 10 June 1977 (fr.), N. A. Rosa Eं M. R. Santos 2089 (MG, MO!, RB213038!).

CONSERVATION STATUS. This species was evaluated in Mamani et al. (2010: 135) as Endangered (EN) under the name Ipomoea rosea. There is no reason to change this classification.

PHENOLOGY. Found in flower towards the end of the summer rainy season from March to May.

ETYMOLOGY. The name "graniticola" refers to the species preferred habitat - islands of vegetation on granite domes and platforms. 


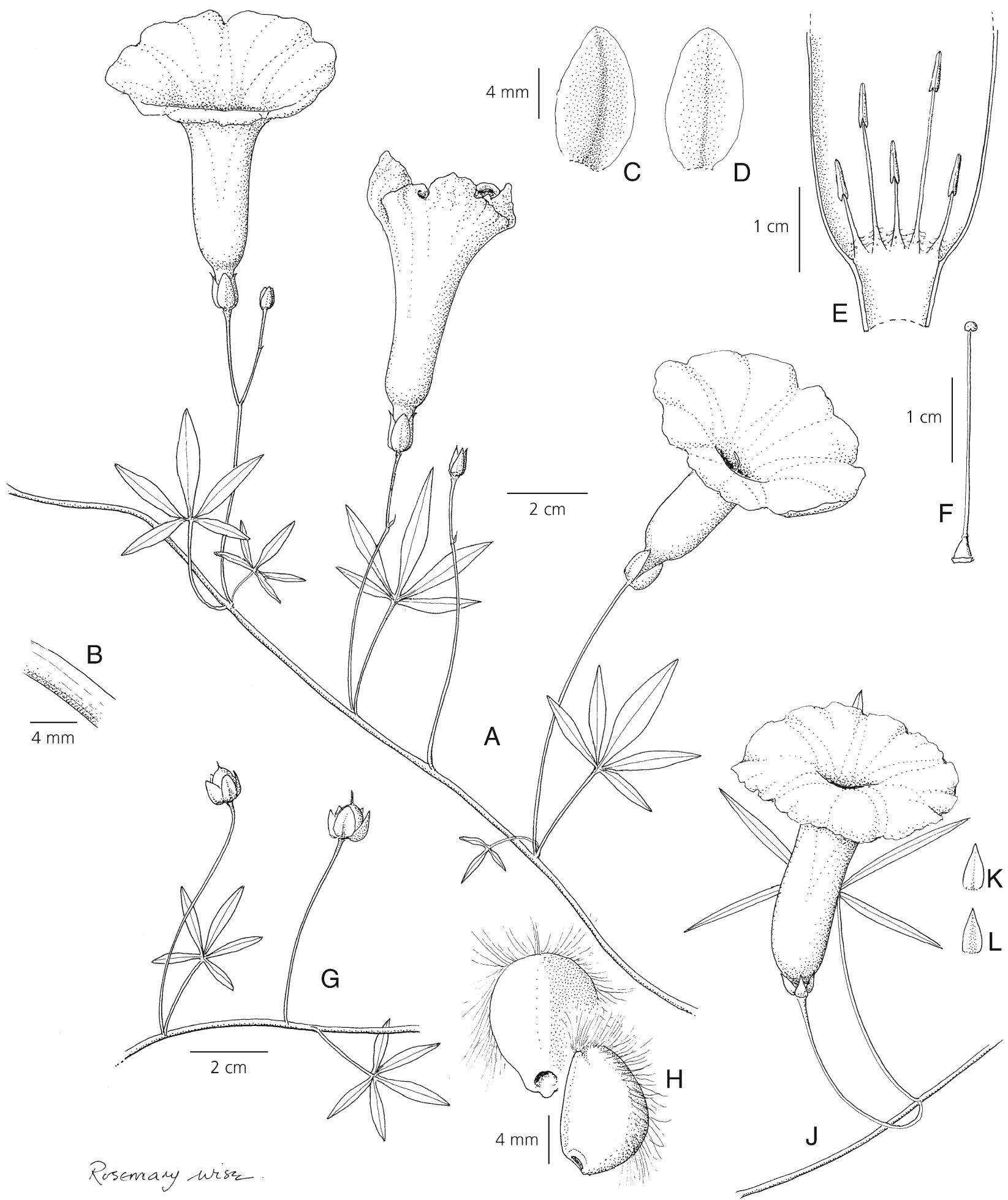

Fig. 19. A - H Ipomoea graniticola. A habit; B stem; C outer sepal; D inner sepal; E corolla opened out to show stamens; F ovary and style; $\mathrm{G}$ shoot with fruiting inflorescence showing capsules; $\mathrm{H}$ seeds. J - L I. subrevoluta. J inflorescence; K outer sepal; L inner sepal. A - F from Wood et al. 27763; G - H from Wood et al. 24991; J - L from Wood et al. 27790. DRAWN BY ROSEMARY WISE.

54. Ipomoea juliagutierreziae $J . R$. I. Wood $\mathcal{E}^{2} R$. W. Scotland, sp. nov. Type: Bolivia, Chuquisaca, Prov. Zudañez, Joya Charal, ANMI El Palmar, una hora de la comunidad en el sector denominado Almendras, "ladera expuesta al cerro Mojocoya con presencia de Harrisia, Capparis y Caesalpinia, suelo rocoso con musgos secos en el suelo. Especie creciendo sobre ramas de Leguminosa", $18^{\circ} 35^{\prime} 20^{\prime \prime S} 64^{\circ} 50^{\prime} 14^{\prime \prime} \mathrm{W}, 1610 \mathrm{~m}$, 
J. Gutiérrez, L. Carrillo, N. Paucar E゚ S. Peres-Cortez 2588 (holotype HSB; isotype fragment OXF).

http:/ /www.ipni.org/urn:lsid:ipni.org:names:77148129-1

Liana with white latex to $3.5 \mathrm{~m}$, stems glabrous with pale brown bark. Leaves not present when plant flowering, petiolate, $4-5.5 \times 2.5-4.5 \mathrm{~cm}$, ovate, apex usually acute to shortly acuminate but occasionally rounded, minutely mucronate, base shallowly cordate to subtruncate, glabrous, abaxially paler, with prominent reddish-brown lateral veins, petioles $1-3 \mathrm{~cm}$, very slender, glabrous. Inflorescence on raceme-like side branches at least $9 \mathrm{~cm}$ long; peduncles short, $3 \mathrm{~mm}$, woody, glabrous, bracteoles, not seen; secondary peduncles $2 \mathrm{~mm}$; pedicels c. $7 \mathrm{~mm}$, widened upwards, glabrous, sepals subequal, $11-12 \times 9 \mathrm{~mm}$, broadly elliptic, rounded, glabrous, the margins scarious; corolla $5.5-6 \mathrm{~cm}$ long when pressed, shortly funnelshaped, the tube c. $3 \mathrm{~cm}$ long, c. $2 \mathrm{~cm}$ wide at mouth, white with dark red throat, limb $6.5-6.7 \mathrm{~cm}$ diam., unlobed; longer stamens held at corolla mouth, shorter included, anthers $4.5 \mathrm{~mm}$; style held at corolla mouth, c. $2.2 \mathrm{~cm}$, strongly bilobed, each lobe subglobose. Capsule (immature) ovoid, c. $15 \mathrm{~mm}$ long, glabrous; seeds (immature) pilose on the margins. Fig. 20.

RECOGNITION. This new species belongs to the Arborescens group of species (McPherson 1981) hitherto represented in South America by three species, Ipomoea pauciflora M. Martens \& Galeotti, I. wolcottiana Rose and I. pulcherrima Ooststr. From the last two I. juliagutierreziae is distinguished by its completely glabrous stems, leaves, sepals and corolla. From I. pauciflora it is distinguished by its liana (not tree-like) habit, obtuse to rounded (not acute) outer sepals and bilobed stigma, each lobe subglobose, $1.25 \times 1.25 \mathrm{~mm}$ (not ellipsoid to cylindrical, $2 \times 1 \mathrm{~mm}$ ). Additionally the leaves and corolla are notably smaller than in typical I. pauciflora. Most significantly molecular sequencing using ITS shows the new species is sister to the clade to which belong all other species we have sequenced of the Arborescens group including material of I. pauciflora from both Mexico and Peru.

TYPIFICATION. The first collection of this species was of a leafless flowering shoot with immature fruits (Gutiérrez et al. 22390). A subsequent collection from the same plant (Gutiérrez et al. 2588) consisted of leaves attached to a branchlet. This material has been selected as holotype as the molecular sequence confirming the distinction of this species was made from this leaf material. The description is of course, a composite based on both collections and the photographs.

DISTRIBUTION \& HABITAT. This species is endemic to Bolivia where it is known from xerophytic bushland and dry forest with Bougainvillea spp., Ruprechtia apetala Wedd., Anadenanthera colubrina (Vell.) Brenan and
Cactaceae spp. at two localities in the Río Grande Valley. It has been found between 1250 and $1600 \mathrm{~m}$ and the soil is reported to be stony. The Río Grande valley is a major centre of endemic species, mostly discovered in recent years, including Bonamia riograndina J. R. I. Wood, Espostoa guentheri (Kupper) Buxb. ex Eggli, Gaya woodii Krapov., Gomphrena stellata Ortuño \& Borsch, Justicia aequilabris subsp. riograndina Wassh. \& J. R. I. Wood, Matelea sartago-diaboli Goyder, Myrocarpus emarginatus A. L. B. Sartori \& A. M. G. Azevedo, Salvia graciliramulosa Epling \& Játiva and Senegalia riograndensis (Atahuachi \& L. Rico) Seigler \& Ebinger. Map 10.

SPECIMENS EXAMINed. Bolivia. Chuquisaca: Prov. Zudañez, Joya Charal, ANMI El Palmar, una hora de la comunidad en el sector denominado Almendras, $18^{\circ} 35^{\prime} 20^{\prime \prime} \mathrm{S} 64^{\circ} 50^{\prime} 14^{\prime \prime} \mathrm{W}, 1610 \mathrm{~m}, 18$ July 2014 , fls only J. Gutiérrez al. 2239 (HSB); ibid., Dec. 2014, lvs only, J. Gutiérrez et al. 2588 (HSB, OXF). Cochabamba: Prov. Campero, Pasorapa, sendero hacia El Angosto,

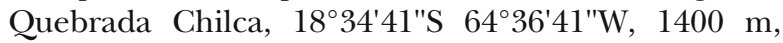
July 2013, N. de la Barra s.n. (photo).

CONSERVATION StATUS. Data deficient (DD). The populations of this species have only recently been discovered and are poorly known. It would be premature to categorise this species but it seems likely to be a very local species with a small number of individual plants so will almost certainly need to be categorised as at least Threatened (EN) because of the size of its populations although it faces no obvious threats apart from possible grazing as a result of the presence of cattle in the area.

PHENOLOGY. Found in flower in July at the height of the winter dry season when the plant is leafless.

EPONYMY. This species is named for Julia Gutiérrez Romero currently responsible for the Herbario del Sur de Bolivia (HSB) and long-time colleague of the first author. As part of a project to investigate the plants of the ANMI El Palmar she discovered the new species and sent photos and other information on which the description is based.

NOTES. This is the only representative of the Arborescens group of species occurring in Bolivia, the record of Ipomoea pauciflora M. Martens \& Galeotti subsp. vargasiana in Austin \& Huáman (1996) being presumably an error as we have been unable to trace any collection or literature reference.

55. Ipomoea paradae $J$. R. I. Wood $\mathcal{E} R$. W. Scotland sp. nov. Type: Bolivia, Santa Cruz, Vallegrande, camino Algodonal a Masicurí, G. A. Parada, M. Betancur E $Y$. Inturion 3151 (holotype USZ; isotypes $\mathrm{K}, \mathrm{MO}$ ).

http://www.ipni.org/urn:lsid:ipni.org:names:77148130-1

Liana reaching at least $5 \mathrm{~m}$ in height, stems woody, glabrous, obscurely ridged, bark pale brown. Leaves 

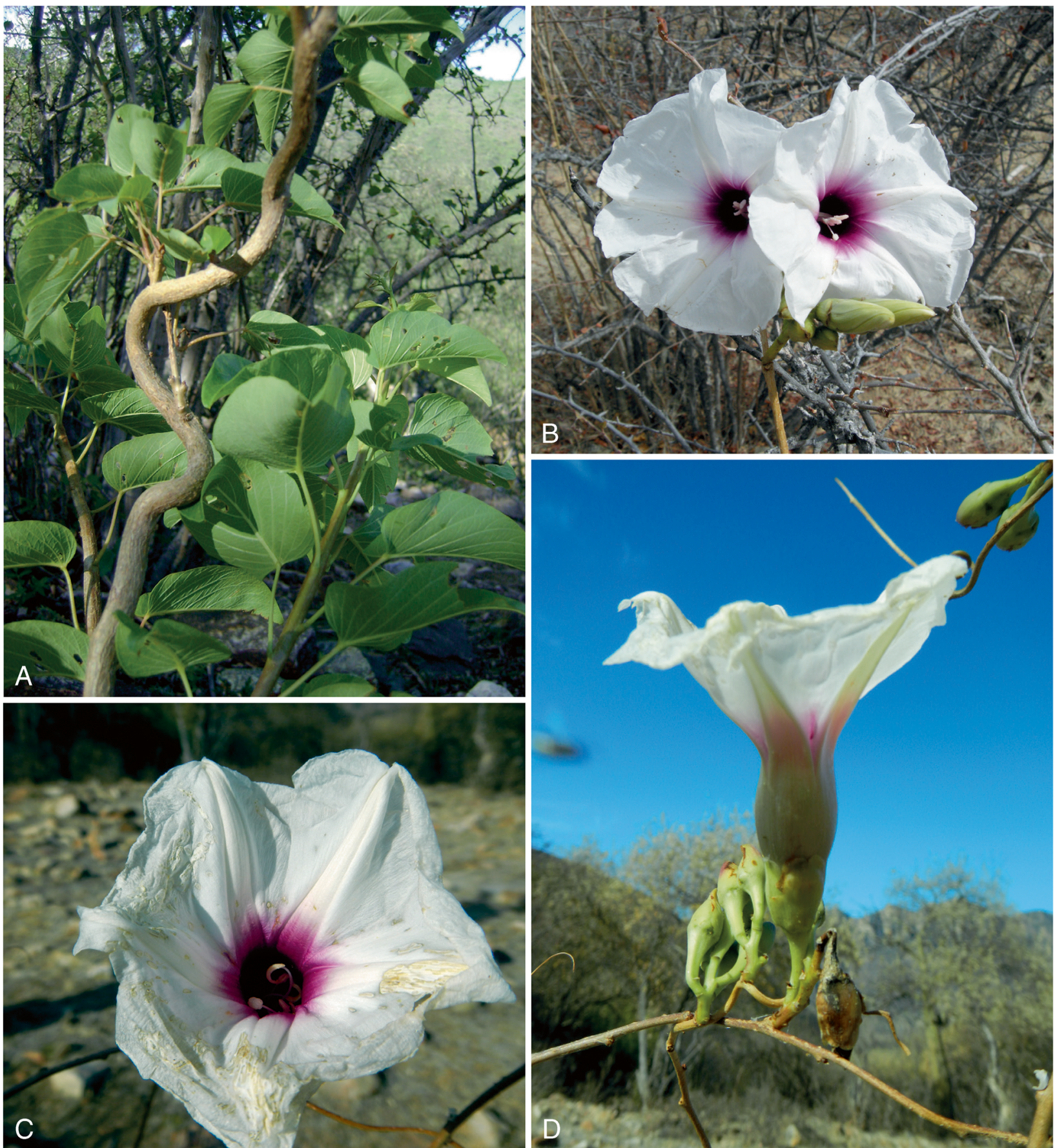

Fig. 20. Ipomoea juliagutierreziae. A liana habit and leaves; B corolla; C corolla mouth showing anthers and stigma; D corolla, side view, showing calyx and inflorescence. PHOTOS: A NORAH PAUCAR; B NELLY DE LA BARRA; C - D JULIA GUTIÉRREZ.

petiolate, $6-12 \times 5.5-11 \mathrm{~cm}$, ovate, obtuse and mucronate, base cordate with rounded auricles, adaxially green, thinly pubescent, abaxially greytomentose with highlighted veins; petioles $3-5 \mathrm{~cm}$, puberulent. Inflorescence of 1 - 5-flowered, axillary, pedunculate cymes; peduncles $1-3.5 \mathrm{~cm}$, glabrous except for hairs apically; secondary peduncles $1-1.4 \mathrm{~cm}$, pubescent; bracteoles $10-14 \times 8-10 \mathrm{~mm}$, oblong-ovate, obtuse, pubescent, deciduous; pedicels 8 - $12 \mathrm{~mm}$, markedly widened upwards, hirsute below, glabrous upwards; sepals subequal, $15-18 \times 10-14 \mathrm{~mm}$, broadly elliptic-obovate, rounded, glabrous, margins scarious; corolla $9-10 \mathrm{~cm}$ long, white with pink centre, funnelshaped with cylindrical basal tube c. $12 \mathrm{~mm}$ long, glabrous, midpetaline bands ending in a small tooth, limb c. $5-6 \mathrm{~cm}$ diam., very shallowly lobed; stamens 
unequal, longer filaments c. $14 \mathrm{~mm}$, shorter filaments c. $10 \mathrm{~mm}$; anthers $6 \mathrm{~mm}$; style c. $2.5 \mathrm{~cm}$; stigma bilobed. Capsule ovoid, $20 \times 15 \mathrm{~mm}$, glabrous; seeds $10 \times 6 \mathrm{~mm}$, flattened ellipsoid, dark brown, long-pilose, the marginal hairs up to $20 \mathrm{~mm}$. Figs 18E, 21.

RECOGNITION. Ipomoea paradae is somewhat similar to I. brasiliana in the indumentum and venation of the leaves and also in the indumentum and size of the sepals but the sepals are always completely glabrous as are the stem and peduncles. The corolla is very distinctive with its white limb and dark red throat, recalling the corolla of I. juliagutierreziae.

DISTRIBUTION \& HABITAT. Endemic to Santa Cruz Department in Bolivia. It grows in forest and forest relics in areas of the Andean foothills which enjoy a moderately dry winter season.

SPECIMENS eXAMINed. BoliviA. Santa Gruz: Prov. Ibañez, Monumento Natural Espejillos, 1753'59"S $63^{\circ} 25^{\prime} 46^{\prime \prime} \mathrm{W}, 500 \mathrm{~m}, 19$ July 2007, G. A. Parada et al. 162 (MO, USZ). Prov. Ichilo, PN Amboró, ridge between Quebrada Yapojé and Quebrada Caballo, 0.5 - $1 \mathrm{~km}$ above confluence with Río Saquayo, 17³4'30"S 6346'W, 400 m, 13 June 1991 (fr.), M. Nee 40966 (NY, USZ). Prov. Vallegrande, camino Algodonal a Masicurí, 1900'36"S 634' 49"W, 542 m, 6 April 2011, G. A. Parada et al. 3151 (K, MO, USZ).

Parada et al. 162 and Nee 40966 are fruiting specimens with glabrous sepals and appear to belong here but in the absence of flowers some doubt about the identity of these collections remains.

CONSERVATION STATUS. Data Deficient (DD). Within Bolivia using Geocat this species comes out as Endangered in terms of its extent of occurrence. There are only three distinct populations but, as very little is known about any of these, it would be premature to assign this classification formally, even though it seems unlikely that further substantial populations will be discovered.

PHENOLOGY. Flowering in March - April at the end of the summer rains.

ETYMOLOGY. This species is named for Alexander Parada, one of the younger generation of Bolivian botanists, whose collections and photographs from the Vallegrande area, in particular, have served to enrich significantly this account of Ipomoea in Bolivia.

Species 56 - 69. These 14 species are part of clade which is particularly diverse in the Caribbean and South America. It is characterised by the rigid, subequal coriaceous sepals, which are usually glabrous. The seeds, where known, are always lanate, with long marginal hairs. One curiosity is the existence of three species pairs which are vegetatively almost identical but differ markedly in the structure of their corolla. These are Ipomoea oranensis and I. exserta, I. schulziana and I. suburceolata and, from the Caribbean, I. eggersiana Peter and I. steudelii Millsp.

56. Ipomoea densibracteata O'Donell (1950b: 438). Type: Bolivia, Santa Cruz, Prov. Cordillera, Cabezas, I. Paredo 453 (holotype LIL).

Vigorous climber or liana to $4 \mathrm{~m}$, stems stout, densely pubescent. Leaves petiolate, $3-9 \times 2-8 \mathrm{~cm}$, ovate, obtuse and mucronate, margin undulate, cordate and cuneate onto the petiole, adaxially green, densely pubescent, beneath grey-subtomentose; petioles $1-3 \mathrm{~cm}$, subtomentose. Inflorescence of solitary bracteate flowers aggregated into dense cymes or racemes; bracts resembling small leaves, peduncles $1-3.5 \mathrm{~cm}$, densely pilose to tomentose; bracteoles foliose, $1.2-2.5 \times 0.5-0.8 \mathrm{~cm}$, oblong-elliptic, obtuse, narrowed to a cuneate base, persistent; pedicels $0-5 \mathrm{~mm}$; sepals hidden by bracteoles, subequal, $8-9 \times 4-6 \mathrm{~mm}$, elliptic, obtuse, coriaceous, concave, somewhat pubescent when young, glabrescent and completely glabrous when in fruit; corolla $5-8 \mathrm{~cm}$ long, funnel-shaped, pink with a darker centre, glabrous, limb 2.5 $4 \mathrm{~cm}$ diam., undulate. Capsule enclosed by persistent bracts, $7-8 \times 5 \mathrm{~mm}$, glabrous, ovoid, rostrate; seeds $5 \mathrm{~mm}$, oblong, long-pilose. Fig. 22C.

DISTRIBUTION \& HABITAT. An uncommon Bolivian endemic from bushy places, scrub and forest margins around the northern and western fringes of the Chaco. Map 15.

SPeCIMens eXAMined. BoliviA. Santa Cruz. Prov. Chiquitos, c. $20 \mathrm{~km} \mathrm{~W}$ of Quimome on serranía on road to Santa Cruz, 400 m, 30 Dec. 1999, J. R. I. Wood $\mathcal{E}$ D. J. Goyder 15735 (K, LPB, USZ); medio km de la tranca de El Tinto al pie de la serranía hacia Laguna Concepción, 17³5'18"S 61²7'37"W, 253 m, 4 March 2011, J. R. I. Wood Ẽ D. Soto 27118 (K, LPB, USZ). Prov. Cordillera, Cabezas, I. Paredo 453 (LIL); PN Kaa Iya del Gran Chaco, Fortin Ravelo, cima del Cerro San Miguelito, 19¹7'46"S 60³7'12"W, 430 m, 7 Feb. 1998, A. Fuentes E G. Navarro 2191 (LPB, USZ); camino de Tucavaca a San José, 4 Feb. 2005, Solis Neffa et al. 1846 (CTES, LPB). Prov. Nuflo de Chávez, Est. San Miguelito, 270 m, 12 Dec. 1995, A. Fuentes 1421 (ARIZ, CPAP, USZ); c. 4 km E of Concepción en el camino a San Ignacio, $16^{\circ} 05^{\prime} 35^{\prime \prime S} 62^{\circ} 00^{\prime} 17^{\prime \prime} \mathrm{W}, 452 \mathrm{~m}$, 21 Jan. 2014, J. R. I. Wood E D. Soto 27919 (K, LPB, OXF, USZ). Prov. Velasco, $12 \mathrm{~km} \mathrm{~S}$ of San Ignacio on road to San Miguel, 400 m, 27 Feb. 1998, J. R. I. Wood et al. 13134 (K, LPB, USZ).

CONSERVATION STATUS. Based on its extent of occurrence this species should be provisionally classified as Least Concern (LC). Although the populations are very dis- 


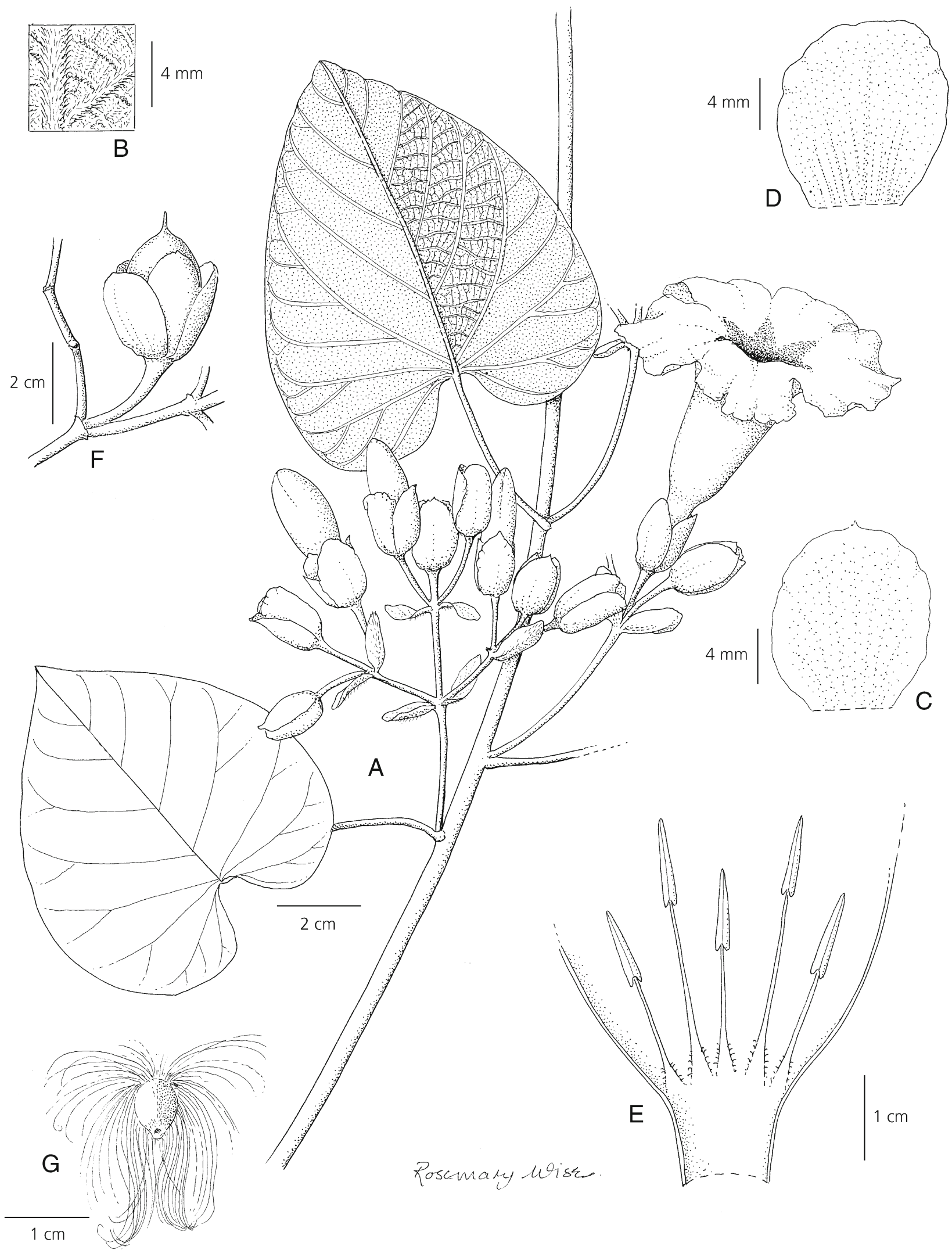

Fig. 21. Ipomoea paradae. A habit; $B$ abaxial leaf surface; $C$ outer sepal; $D$ inner sepal; $E$ corolla opened out to show stamens; $F$ fruiting calyx and capsule; G seed. A - E from Parada et al. 3151; F - G from Parada et al. 162. DRAWN BY ROSEMARY WISE. 

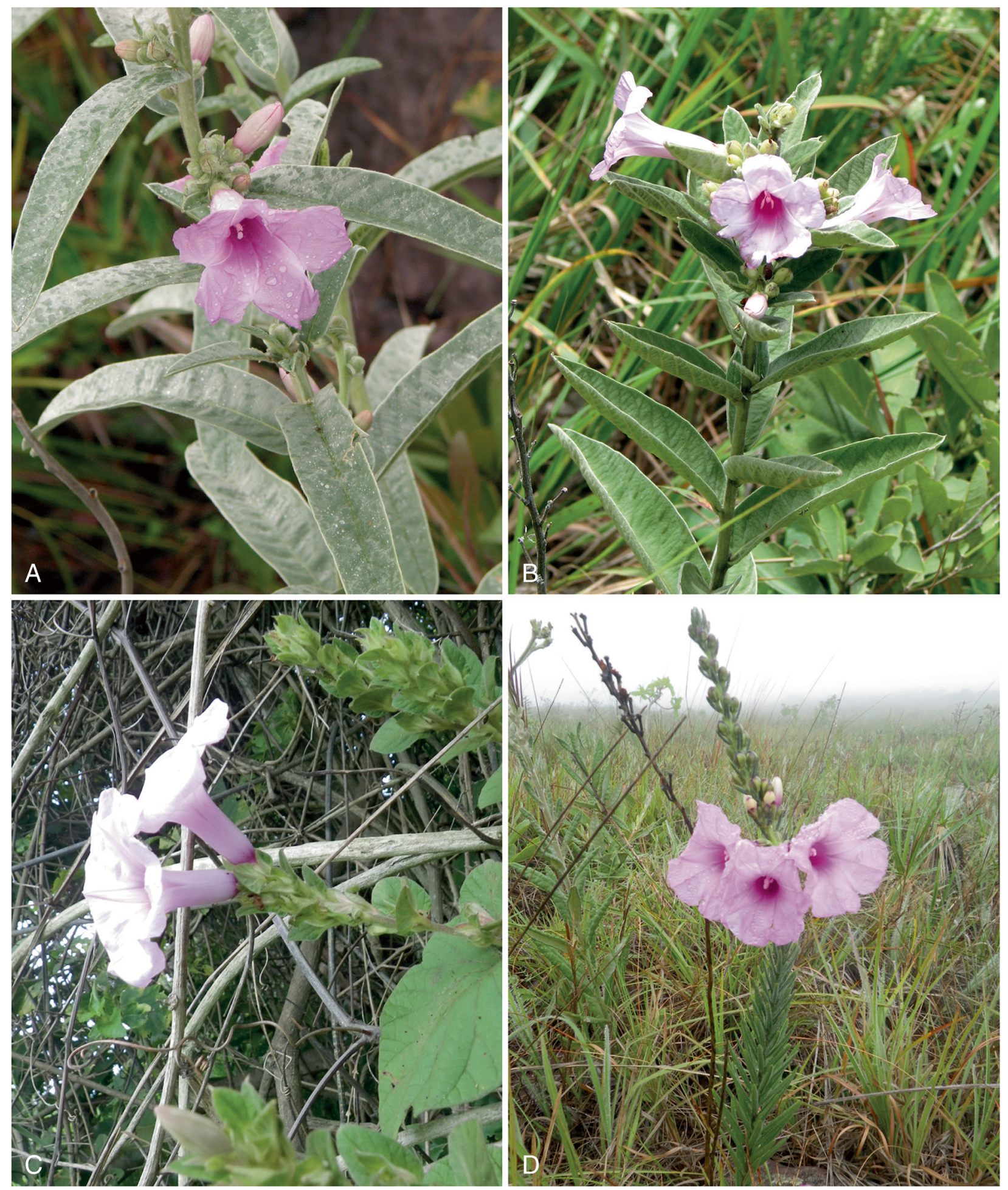

Fig. 22. A Ipomoea argentea sericeous-leaved form; B I. argentea tomentose-leaved form; C I. densibracteata; D I. paulistana. PHOTOS: A - B DARWIN INITIATIVE PROJECT 16-004; C - D JOHN WOOD.

persed it is likely to be under-recorded as the Chaco region is poorly explored botanically and it thrives in areas of disturbed scrub and on forest margins.
PHENOLOGY. This is a species with a distinct, but brief flowering season being found in flower from December to February. 
NOTES. A very distinctive species because of its bracteate inflorescence and persistent bracteoles combined with the coriaceous, concave sepals.

57. Ipomoea argentea Meisn. (Meisner 1869: 247). Types: Brazil, Goyas et Pianhy, G. Gardner 3356 (lectotype BR 0000005837519!, designated here, isolectotype $\mathrm{K}$ !).

Batatas villosa Choisy (1845: 337). Types: Brazil, Sao Paulo, Ytu, Martius 609 (syntype M).

Ipomoea villosa (Choisy) Meisn. (Meisner 1869: 244), non I. villosa Ruiz \& Pavon (1799).

Ipomoea stachyoides Meisn. (Meisner 1869: 240). Type: Brazil, Goiás, Burchell 6586 (holotype BR!, isotypes $\mathrm{K}$ !, P!).

Erect perennial, stem stout and somewhat woody, often simple, white-tomentose, $0.3-1 \mathrm{~m}$ high. Leaves subsessile, $2.5-10(-14) \times 2-3.5(-5.5) \mathrm{cm}$, broadly oblong to oblong-elliptic, acute and sometimes mucronate, cuneate to rounded at base, densely sericeous or tomentose on both surfaces, upper surface greenish, lower surface grey; petioles $0-5 \mathrm{~mm}$. Inflorescence terminal, formed of sessile or shortly pedunculate compact cymes from the upper leaf axils, cymes commonly single-flowered but sometimes with $2-10$ flowers; peduncles $0-2.5 \mathrm{~cm}$, tomentose; bracteoles linear-lanceolate to ovate, up to $10 \times 5 \mathrm{~mm}$, hirsute, somewhat persistent; pedicels $1-3 \mathrm{~mm}$; sepals subequal, $7-9 \mathrm{~mm}$, elliptic, obtuse, coriaceous, concave, brown when dry, the outer villous but glabrescent, inner glabrous; corolla $5-6 \mathrm{~cm}$, funnelshaped, pink, glabrous, limb c. $4 \mathrm{~cm}$ diam., distinctly lobed. Capsule glabrous, ellipsoid, $8 \times 6 \mathrm{~mm}$, very shortly rostrate; seeds c. 3 mm, long-pilose. Fig. 22A, B.

TYPIFICATION. Meisner cited two syntypes, Gardner 3356 and Spruce 3605. Of these two we have selected Gardner 3356 (BR) as lectotype as it is the only one represented in Martius' herbarium. It is also the most similar to the common form of this species in Brazil which is similar to the plant from Santo Corazón (Fig. 22B) whereas the Spruce specimen has more sericeous leaves similar to the form from the Noel Kempff Park, which has a more lustrous appressed sericeous indumentum (Fig. 22A). Further investigation is required to assess whether these forms are of taxonomic significance.

DISTRIBUTION \& HABITAT. A characteristic species of cerrado in Brazil extending to Paraguay, Brazil and to the llanos of Venezuela and Colombia. In Bolivia it is common in rocky cerrados on and below the meseta in the Noel Kempff Park but only known elsewhere from Cerro Pelón near Santo Corazón.

SPECIMEnS EXAMINED. BoliviA. Santa Gruz: Prov. Ángel Sandoval, Cerro Pelón, SW of Santo Corazón, $18^{\circ} 00^{\prime} 34^{\prime \prime S} 58^{\circ} 54^{\prime} 05^{\prime \prime W}, 784 \mathrm{~m}, 1$ March 2009, J. R. I. Wood et al. 25639 (USZ). Prov. Velasco, PNNKM, Las Gamas 1449'24"S 60²3'10"W, 920 m, 6 Nov. 1993 R. Guillén Ẽ T. Centurion 845 (ARIZ, BOLV, F, FTG, MO, NY, USZ); ibid., 14²48'30"S 60²4'17"W, 850 m, 28 Oct. 1995, T. Killeen E T. Grinwood 7772 (MO, USZ); ibid., 1449'36"S 60²3'10"W, 850 m, 30 Oct. 1995, A. Rodriguez Eं J. Surubi 578 (ARIZ, MO, NY); PNNKM, camino a El Encanto, 14 34'56"S 6050'01"W, 260 m, 6 Nov. 1995, A. Rodriguez E P. F. Foster 754 (MO); PNNKM, Flor de Oro, 133'39"S 6101'07"W, $200 \mathrm{~m}$, 10 June 1994, E. Gutiérrez et al. 1396 (USZ); PNNKM, Camp. La Laja, subiendo la meseta, 14²0'07"S 60²7'27"W, 614 m, 15 Nov. 2003, J. R. I. Wood et al. 19974 (K, LPB); Camp. Huanchaca 2, 14³2'11"S 6044'15"W, 769 m, 4 Nov. 2008, J. R. I. Wood et al. 25244 (K, LPB, UB, USZ).

CONSERVATION STATUS. Data Deficient but probably Least Concern (LC). In Bolivia this species is only known from two protected areas, the PN Noel Kempff Mercado and the ANMI San Matías. It appears to be common in the former, particularly on the vast, inaccessible meseta, while the Serranías de Sunsas are so poorly known that it is impossible to speculate about its frequency in this region from a single collection.

PHENOLOGY. It flowers principally at the onset of the first rains in October and November but may be found flowering sporadically at other times.

NOTES. A very distinct species for its erect habit, subsessile silvery leaves and lobed corolla.

58. Ipomoea paulistana (Silva Manso) Stellfeld (1945: 86). Convolvulus paulistanus Silva Manso (1836: 17). Type: not specified, Brazil, Mato Grosso, Cuyaba, Silva Manso $\mathcal{E}$ L Lhotsky 32 (G 00135526, lectotype, designated here),

Ipomoea echioides Choisy (1838: 54), synon. nov. Type: Brazil. Mato Grosso, Serra-Nov, Silva Manso $\mathcal{E}^{\circ}$ Lhotsky 32 (syntype G 00135526).

Erect herb to c. $0.75 \mathrm{~cm}$, usually unbranched, stems pubescent, often leafless below. Leaves sessile, numerous, imbricate, $0.5-6(-13) \times 0.1-0.5(-1.2) \mathrm{cm}$, diminishing in size upwards, linear-oblong, base narrowly cuneate, apex acute, mucronate, margins commonly inrolled, both surfaces densely softly pilose or pubescent. Inflorescence terminal, \pm racemose in appearance, up to $30 \mathrm{~cm}$ long, formed of cymes, which are often reduced to solitary flowers arising in the axils of the leaf-like bracts; peduncles $0-3 \mathrm{~cm}$ (often absent), erect; bracteoles $3-$ $10 \mathrm{~mm}$, linear, pilose, deciduous; pedicels $2-6 \mathrm{~mm}$; sepals 5- $7 \mathrm{~mm}$, subequal, elliptic, usually truncate, rigid, concave, the outer pubescent, acute, the inner subglabrous; corolla $5-6 \mathrm{~cm}$, pink, funnel-shaped, glabrous, limb $3-4 \mathrm{~cm}$ diam., weakly lobed. Capsule globose, 4 - $5 \mathrm{~mm}$ diam., glabrous, apex shortly rostrate, 
the dead style remaining until the fruit matures; seeds c. $3 \mathrm{~mm}$, long-pilose. Fig. 22D.

TYPIFICATION. Although this species has been generally known as Ipomoea echioides, the correct name is I. paulistana. It was originally described by Silva Manso as Convolvulus paulistanus but no type was specified. Although Choisy cited this publication, he chose to ignore it so probably rendering the name Ipomoea echioides superfluous. As a type he cited a collection by Silva Manso and Lhotsky from Cuaibá in Mato Grosso. This is presumably Silva Manso $\mathcal{E}$ Lhotsky 32 at Geneva which was duplicated at Berlin as shown by the photograph at the Field Museum. This is probably the material used also by Silva Manso for his Convolvolvulus paulistanus and is here selected as lectotype of this species. Silva Manso worked in Cuiabá from 1823 and the specimen must have been collected between 1830 and 1832 as it was only during these years that Lhotsky was in Brazil (Stafleu \& Cowan 1981: 283). We have seen no other material suitable for lectotypification.

DISTRIBUTION \& HABITAT. A characteristic cerrado species of Bolivia and Brazil, somewhat more widespread in Bolivia than other cerrado species, occurring in both Santa Cruz and Beni departments from around 200 to $900 \mathrm{~m}$.

SPECIMENS EXAMINED. BOLIVIA. Beni: Prov. Vaca Diaz, Pampas de San Lorenzo, km 36 on road from Riberalta to Guayaramerin, $11^{\circ} 01^{\prime} \mathrm{S}, 65^{\circ} 44^{\prime} \mathrm{W}, 19$ Jan. 1999, P. Maas et al. 8722 (MO, NY). Santa Cruz: Prov. Chiquitos, Serranía de Santiago de Chiquitos, $18^{\circ} 19^{\prime} \mathrm{S} 59^{\circ} 34^{\prime} \mathrm{W}, 900 \mathrm{~m}$, 25 Jan. 2001, J. R. I. Wood E $D$. J. Goyder 16968 (K, LPB, USZ); near el Arco on trail from Santiago de Chiquitos hacia la cueva, $18^{\circ} 20^{\prime} 37^{\prime \prime} \mathrm{S}$ 59 33'39"W, 850 m, 30 Dec. 2002, J. R. I. Wood 18824 (K, LPB). Prov. Velasco, PNNKM, 1449'S 60²3'W, 900 m, 27 March 1993, T. J. Killeen et al. 4778 (MO); ibid., on meseta returning to Los Fierros, 14 33'35"S 6045'50"W, 800 m, 10 March 1997, S. Jiménez Ẽ E. Gutiérrez 1386 (MO); ibid., Camp. Viejo Los Fierros, $14^{\circ} 34^{\prime} \mathrm{S} 60^{\circ} 49^{\prime} \mathrm{W}, 225 \mathrm{~m}, 10$ April 1994, M. Saldias et al. 3811 (MO); ibid., 14³5'13"S 6050'25"W, 200 m, 14 March 1997, L. Sánchez et al. 253 (ARIZ, FTG, MO); ibid., 14³3'28"S 6055'51"W, 200 m, 15 March 1997, L. Sánchez et al. 306, (USZ); zona de Camp. Huanchaca 2, meseta de Caparuch, 750 m, 20 April 2002, J. R. I. Wood et al. 18213 (K, LPB); Hac. Acuario, 15¹4'46"S 61 14'34"W, 300 m, 24 Jan. 1997, R. Guillén et al. 309 (ARIZ, FTG, MO, OXF).

CONSERVATION STATUS. Based on its occurrence in protected areas and the extent of its occurrence this should be provisionally classified as Least Concern (LC). However the number of populations is small and this categorisation might require revision after the populations have been monitored more carefully.

PHENOLOGY. It flowers briefly from December to March.
NOTES. Very distinctive because of its imbricate leaves which diminish in size upwards. It is occasionally confused with Ipomoea argentea but the leaves are never silvery-tomentose as in that species.

59. Ipomoea schomburgkii Choisy (1845: 354). Type: Guyana, R. Schomburgk 692 (holotype K000612791!).

Ipomoea graminiformis Meisn. (Meisner 1869: 250). Type: Brazil, Goyaz, Burchell 8556 (holotype BR000005305780!; isotype K000612790!).

Glabrous perennial herb with xylopodium and erect, somewhat succulent stems to $50 \mathrm{~cm}$. Leaves sessile, $4-16 \times 0.1-3 \mathrm{~cm}$, linear, somewhat glaucous, tapering at both ends, acute. Inflorescence \pm terminal, up to $30 \mathrm{~cm}$ long, but usually much less, formed of pedunculate cymes from the uppermost leaf axils; peduncles $0-5 \mathrm{~cm}$, diminishing in size upwards; bracteoles filiform, up to $10 \mathrm{~mm}$ long, caducous; pedicels 5 - $13 \mathrm{~mm}$; sepals subequal, coriaceous, somewhat concave, $5-7 \times 3-4 \mathrm{~mm}$, elliptic, outer acute to obtuse, c. $1 \mathrm{~mm}$ shorter than inner, inner rounded, slightly scarious on margins; corolla c. $4.5 \mathrm{~cm}$ long, pink with a darker centre, glabrous, limb weakly lobed, c. $4 \mathrm{~cm}$ diam. Capsule and seeds not seen. Fig. 18F.

DISTRIBUTION \& HABITAT. Scattered on seasonally flooded plain at low altitudes in South America from the Guyanas, Venezuela and Colombia south to Bolivia and Paraguay but nowhere common. In Bolivia a rare species of flooded pampa in the zone of Luisita (Iturralde, La Paz) and El Refugio (Velasco, Santa Cruz).

SPECIMENS EXAMINED. BOLIVIA. La Paz: Prov. Iturralde, Luisita, W del Río Beni, $13^{\circ} 05^{\prime} \mathrm{S} 67^{\circ} 15^{\prime} \mathrm{W}, 180 \mathrm{~m}, 28$ Feb. 1984, S. G. Beck Eं R. Haase 10100 (LPB); ibid., 2 May 1988, R. Haase 801 (LPB); ibid., 2 Dec. 1988, R. Haase 840 (LPB). Santa Cruz: Prov. Velasco, El Refugio, $14^{\circ} 44^{\prime} 36^{\prime \prime S} 61^{\circ} 01^{\prime} 12^{\prime \prime W}, 150$ m, 23 Jan. 1995, R. Guillén Ė V. Roca 2992 (ARIZ, LPB, MO, USZ); Pampas de El Toledo, 1443'22"S 61 08'28"W, 354 m, 19 Jan. 2014, J. R. I.Wood E D. Soto 27914 (K, LPB, OXF, USZ).

CONSERVATION STATUS. In Bolivia this species is only known from two areas and should be provisionally classified as Endangered (EN) as it is unlikely to occur elsewhere in any frequency given its rarity in neighbouring countries. However, the flooded pampa which it grows in is of no potential agricultural value and so there is no obvious immediate threat to its survival.

PHENOLOGY. Found in flower from December to early May.

NOTES. Readily distinguished by the herbaceous, slightly fleshy stems, linear leaves, subequal sepals, glabrous corolla and distinctive habit and habitat. 
60. Ipomoea batatoides Choisy (1838: 58). Type: Brazil, Bahia, Blanchet (holotype G-DC, not seen)

Ipomoea philipsonii O'Donell (1953: 378), synon. nov. Type: W. R. Philipson, J. M. Idrobo Eं A. Fernandez 1396 (holotype BM!).

Twining perennial to $4 \mathrm{~m}$, stems usually glabrous. Leaves petiolate, $3-11 \times 2.5-8 \mathrm{~cm}$, ovate, weakly cordate with rounded auricles, shortly acuminate to an acute apex, occasionally slightly undulate-denticulate or weakly 3lobed, glabrous or, rarely, pubescent, lower surface paler, often dotted with glands or minute hair bases; petioles $2-7$ $\mathrm{cm}$, characteristically slender. Inflorescence of lax pedunculate, axillary cymes; peduncles $3-10 \mathrm{~cm}$; secondary peduncles $1.5-3 \mathrm{~cm}$, bracteoles filiform, $4 \mathrm{~mm}$, caducous; pedicels 5-15 mm long; sepals subequal, coriaceous and somewhat concave, $6-10 \times 5 \mathrm{~mm}$, broadly oblong, rounded, usually glabrous, margins narrowly scarious; corolla $4-8 \mathrm{~cm}$, inflated above a narrow basal tube, then gradually widened, pink or, less commonly, white, glabrous, limb $5-6 \mathrm{~cm}$ diam., unlobed. Capsule $8 \times 6 \mathrm{~mm}$, ellipsoid, glabrous, rostrate, seeds woolly.

DISTRIBUTION \& HABITAT. In Bolivia, a rare but possibly undercollected species of moist tropical forest at altitudes below $900 \mathrm{~m}$.

SPECIMENS eXAMINED. BoliviA. Cochabamba: Prov. Carrasco, Río Blanco, sector Puerto Cotagaita, $17^{\circ} 13^{\prime} 45^{\prime \prime S} 64^{\circ} 28^{\prime} 40^{\prime \prime W}, 255 \mathrm{~m}, 30$ May 2004, O. Colque $\mathcal{E}$ L. Mendoza 196 (MO, OXF, USZ). La Paz: Prov. Caranavi, 5 - $10 \mathrm{~km} \mathrm{E}$ of Caranavi along road to Carrasco and Alto Beni, 900 m, 4 May 2002, J. R. I. Wood E T. Daniel 18399 (HSB, K, LPB). Prov. Sud Yungas, camino Chulumani-Asunta, entre Chamaca y San Bartolomé, 16 $12^{\prime} 53$ "S 67¹0'75"W, 893 m, 2 April 2004, J. R. I. Wood et al. 20623 (LPB). Santa Cruz: Prov. Velasco, Bajo Paraguá, $5 \mathrm{~km}$ from Aserradero Cerro Pelao, 14 33'S 61 ${ }^{\circ} 30^{\prime} \mathrm{W}, 250$ m, 13 May 1994, T. Killeen 6311 (MO, USZ); ibid., T. Killeen Ẽ J. Wellens 6312 (ARIZ, LPB, MO, USZ); $25 \mathrm{~km}$ from Florida towards La Mechita, 1463'54"S, 61 35'90"W, 247 m, 24 April 2009, J. R. I. Wood et al. 26095 (K, LPB, UB, USZ).

CONSERVATION STATUS. Although rare in Bolivia, the records are from widely dispersed areas and it is probably under-recorded as it is found throughout the neotropics. It should be provisionally classified as Least Concern (LC) unless the few Bolivian records can be shown to reflect a genuine rarity.

PHENOLOGY. Found in flower in Bolivia at the end of the rainy season in April and May.

NOTES. The only moist forest species with concave, coriaceous, subequal sepals. Plants are usually glabrous and the leaves often dotted beneath. Whiteflowered forms occur in the Yungas of La Paz and can be easily mistaken for Ipomoea reticulata but the calyx and corolla are both larger, the sepals coriaceous and concave with only very narrow scarious margins.
61. Ipomoea goyazensis Gardner (1842b: t. 479). Type: not found at $\mathrm{BM}, \mathrm{K}$ or $\mathrm{OXF}$, possibly the original image.

Ipomoea decora Meisn. (Meisner 1869: 272). Type: Brazil. Goiás, Pohl 1760 (isotypes K!, OXF!).

Twining perennial liana to $6 \mathrm{~m}$, stems rather thin but slightly woody, usually completely glabrous but rarely appressed pilose. Leaves petiolate, $4-12 \times 3-10 \mathrm{~cm}$, ovate-deltoid, obtuse and mucronate, both surfaces glabrous or pubescent, adaxially dark green, abaxially very pale with prominent venation; petiole rather short, $1.5-3.5 \mathrm{~cm}$. Inflorescence of subsessile, clustered cymes; peduncles 1 - $6 \mathrm{~mm}$, glabrous; bracteoles scale-like, caducous; pedicels $0-7 \mathrm{~mm}$, glabrous; sepals subequal, 7 - $10 \mathrm{~mm}$, elliptic, obtuse to rounded, concave, coriaceous, glabrous, whitish-green when fresh, inner sepals with scarious margins; corolla $5-6 \mathrm{~cm}$, funnelshaped, gradually widened from base, glabrous, tube white, limb deep pink, weakly lobed, $2-2.5 \mathrm{~cm}$ diam. Capsule (immature), subglobose, glabrous. Fig. 23A.

DISTRIBUTION \& HABITAT. A characteristic species of the cerrado biome in Brazil and Bolivia. In Bolivia only known from two collections in Velasco province. The Santa Rosa population was growing in cerradão and the Caparuch population in what appears to be a similar habitat.

SPECIMENS EXAMINED. BOLIVIA. Santa Cruz: Prov. Velasco, PNNKM, Serranía de Caparuch, sobre farellon en el norte, 1339'S 6054'W, 850 m, 21 April 1993, T. J. Killeen et al. 5399 (ARIZ, MO); 20 - 30 km N of Santa Rosa de la Roca en el camino a Piso Firme, 15 44'12"S 61 $31^{\circ} 04^{\prime \prime W}, 384$ m, 13 April 2013, J. R. I. Wood et al. 27806 (K, LPB, OXF, USZ). CONSERVATION STATUS. Data Deficient (DD). The Santa Rosa population must be critically endangered as it is small and lies close to the road but there could be other populations in the extensive but vulnerable cerrados of that region. Nothing is known of the population on the meseta in The Noel Kempff Park but the cerrados are extensive on the vast meseta and a final decision on its status must wait until this area is better known. However, it should be noted that Ipomoea goyazensis is not very common in Brazil.

PHENOLOGY. Recorded in flower in April.

NOTES. A very distinctive species in the field because of its discolourous leaves and trumpet-shaped corolla with a white tube and pink limb. Herbarium specimens are usually easily identified by the subsessile, clustered flowers with coriaceous, concave sepals.

62. Ipomoea schulziana O'Donell (1948: 186). Type: Argentina, Salta, Oran, San Pedrito, senda a Astillero, Schulz 5483 (holotype LIL107492!).

Robust twining liana reaching at least $6 \mathrm{~m}$ in height, commonly leafless when flowering, roots tuberous, stems 

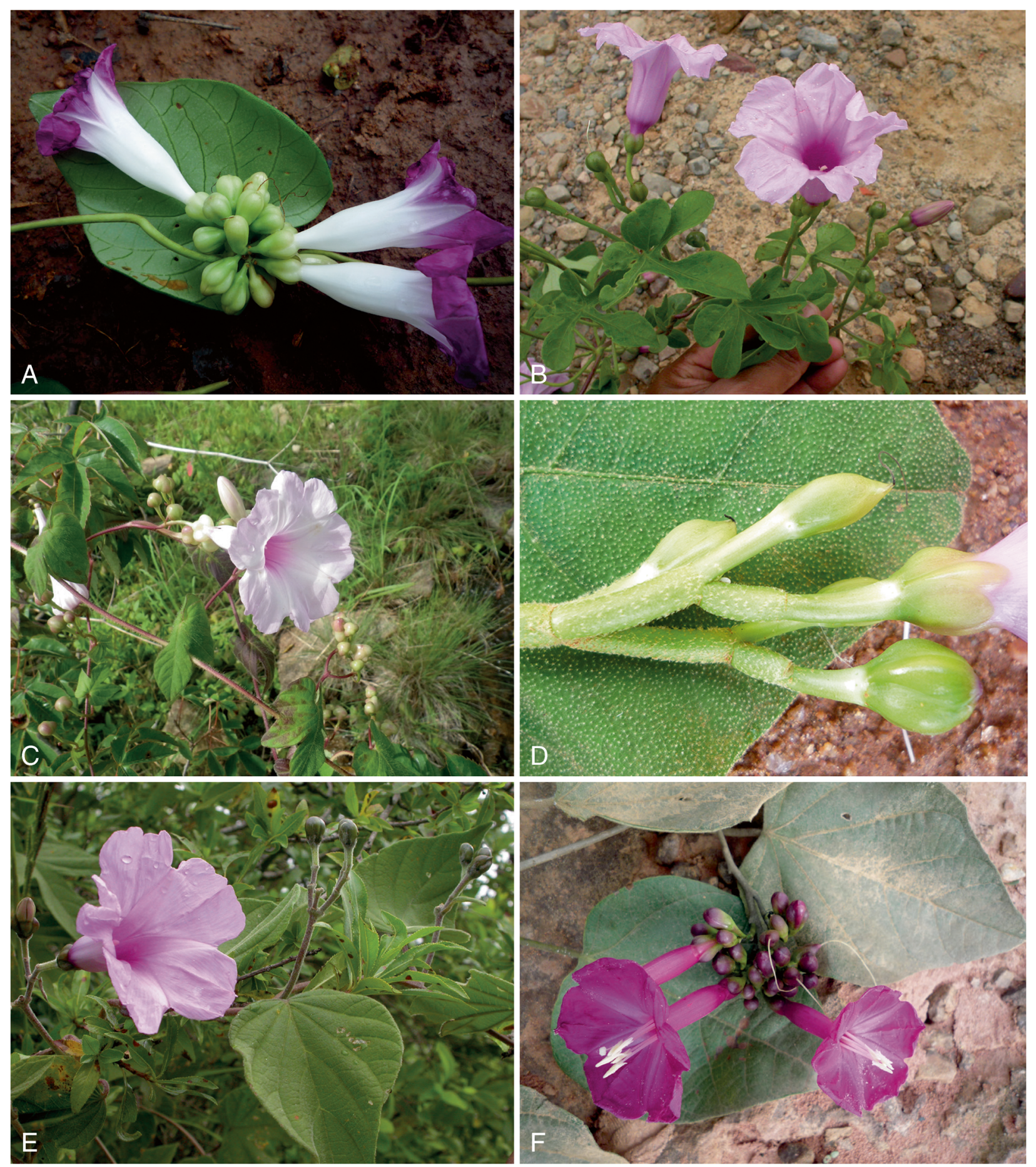

Fig. 23. A Ipomoea goyazensis; B I. cheirophylla; C I. caloneura; D I. bonariensis; E I. oranensis; F I. exserta. PHOTOS: A, D, F BETH WILLIAMS; B, E DARWIN INITIATIVE PROJECT 162/11/010; C JOHN WOOD.

glabrous. Leaves petiolate, mostly $3-8 \times 1.5-4 \mathrm{~cm}$, oblong-ovate, acute and mucronate, basally broadly cordate to truncate, margin slightly undulate, glabrous, adaxially green, abaxially somewhat glaucous and with prominent veins; petioles $1-3.5 \mathrm{~cm}$. Inflorescence of axillary, pedunculate simple or compound cymes often developing on axillary branchlets, sometimes very dense and floriferous or panicle-like; peduncles $0.5-5 \mathrm{~cm}$ long; bracteoles caducous, not seen; secondary peduncles $0.5-2.5 \mathrm{~cm}$; pedicels $3-8 \mathrm{~mm}$, thickened upwards; sepals slightly unequal, coriaceous, glabrous, outer sepals $5-6 \mathrm{~mm}$, concave, elliptic, obtuse with scarious 
margins, the inner $7-8 \mathrm{~mm}$, suborbicular, rounded; corolla $5-6.5 \mathrm{~cm}$, pink, glabrous, funnel-shaped, limb c. $3 \mathrm{~cm}$ diam., unlobed. Capsule glabrous, seeds pilose on the angles.

DISTRIBUTION \& HABITAT. A characteristic species of open dry woodland in the Inter-Andean dry valleys and Bosque Serrano Chaqueño between 850 and 2100 $m$ from Campero Province in Cochabamba Department south to Salta and Jujuy in northern Argentina. There is a single record from the Chaco suggesting links between this region and the interAndean dry valleys seen also in Ipomoea sericosepala. Map 13.

SELECTED SPECIMENS OF 22 EXAMINED. BOLIVIA. Chuquisaca: Prov. Boeto, $18 \mathrm{~km}$ de Nuevo Mundo hacia Vallegrande, 1300 m, 6 July 1995, M. Kessler 5198 (LPB). Prov. Oropeza, Puente Chaquimayu, trayecto Sucre-Surima, $18^{\circ} 58^{\prime} 54^{\prime \prime} \mathrm{S}$ $65^{\circ} 09^{\prime} 50 " \mathrm{~W}, 1976 \mathrm{~m}, 22$ Feb. 2004, J. R. I. Wood E J. Gutiérrez 20232 (BOLV, HSB, K, LPB). Prov. Sud Cinti, Com. Las Abras, $21^{\circ} 02^{\prime} 24^{\prime \prime S} 64^{\circ} 13^{\prime} 08^{\prime \prime} \mathrm{W}, 862 \mathrm{~m}, 6$ Oct. 2005, R. Lozano et al. 1375A (MO). Prov. Tomina, $850 \mathrm{~m}$ above Llantoj, descending from Las Juntas, $19^{\circ} 19^{\prime} \mathrm{S} 64^{\circ} 04^{\prime} \mathrm{W}, 1125 \mathrm{~m}, 11$ Oct. 2004, J. Gutiérrez et al. 996 (HSB, MO, NY). Cochabamba: Prov. Campero, on descent to Río Mizque from Totora on road to Aiquile, $2100 \mathrm{~m}, 19 \mathrm{Feb}$. 1995, J. R. I. Wood 9466 (BOLV, K, LPB). Santa Cruz: Prov. Caballero, cerca de la cumbre sobre el camino entre Pulquina y Saipina, $18^{\circ} 05^{\prime} 53^{\prime \prime S} 64^{\circ} 30^{\prime} 18^{\prime \prime} \mathrm{W}, 1785 \mathrm{~m}$, 30 March 2013, J. R. I. Wood et al. 27705 (K, LPB, OXF, USZ). Prov. Cordillera, Camiri, $20^{\circ} 00^{\prime} \mathrm{S}$, $63^{\circ} 15^{\prime} \mathrm{W}, 850 \mathrm{~m}, 24$ Aug. 1949, W. M. A. Brooke 5546 (BM, NY, F); cruce camino San José -Salinas con gaseoducto Bolivia-Brazil, $17^{\circ} 56^{\prime} 08^{\prime \prime} \mathrm{S}$ $60^{\circ} 47^{\prime} 29^{\prime \prime W}, 230 \mathrm{~m}, 26$ July 1997, A. Fuentes $\mathcal{E} \mathrm{G}$. Navarro 2012 (USZ). Prov. Florida, along dirt road from Mairana to Alto Mairana, $18^{\circ} 08^{\prime} \mathrm{S} 64^{\circ} 00^{\prime} 30^{\prime \prime} \mathrm{W}$, 1415 m, 8 May 1998, M. Nee 49260 (NY, USZ). Prov. Vallegrande, camino de Naranjos a Pampa Negra, $18^{\circ} 25^{\prime}$ - 28'S 64 $14^{\prime}-16^{\prime} \mathrm{W}, 1890$ - $1970 \mathrm{~m}, 31$ May 2010, G. A. Parada $\mathcal{E}$ V. Rojas 2652 (MO, OXF, USZ). Tarija: Prov. Arce, $21^{\circ} 15^{\prime} 28^{\prime \prime S} 64^{\circ} 11^{\prime} 41^{\prime \prime} \mathrm{W}, 935$ m, 8 Oct. 2005, S. G. Beck et al. 31416 (LPB). Prov. Gran Chaco, ANMI Aguaraque, Carapari, $21^{\circ} 39^{\prime} 01^{\prime \prime S} 63^{\circ} 40^{\prime} 04^{\prime \prime} \mathrm{W}, 1140 \mathrm{~m}$, 28 Sept. 2007, A. Lliully 980 (HSB).

CONSERVATION STATUS. Including its limited presence in Argentina this species has a considerable area of occurrence at $\pm 161,670 \mathrm{~km}^{2}$ and should be classified as Least Concern (LC) on this basis. The scattered records mainly reflect lack of recording rather than lack of occurrence. It is unlikely to be frequent in the eastern part of its range (the Chaco) but may be more widespread than is currently known in this botanically unexplored region.

PHENOLOGY. Although collected in nearly every month of the year it characteristically flowers in the winter dry

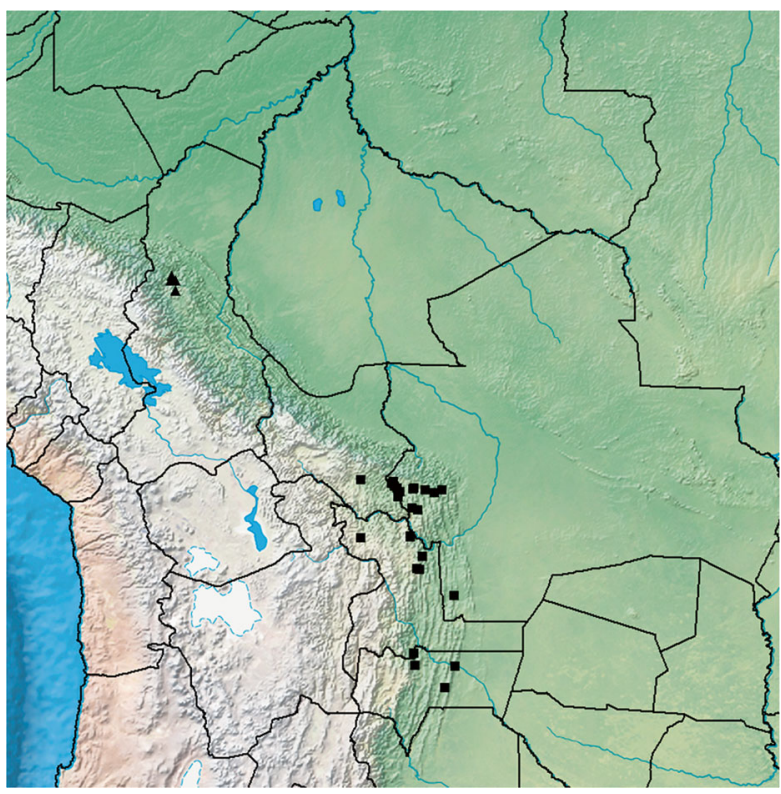

Map 13. Contrasting distributions of Ipomoea schulziana ( $\square$ ), a common species of the inter-Andean dry valleys and the Bosque Serrano Chaqueño, and Ipomoea suburceolata ( $\boldsymbol{\Lambda})$, a local endemic of the Apolo area.

season from May to October, flowering plants often being leafless when collected towards the end of this period.

NOTES. Very similar vegetatively to Ipomoea suburceolata but easily distinguished by the funnel-shaped corolla with a well-developed entire limb. It has also often been misidentified as I. batatoides but differs in the leaf shape and inflorescence structure, the flowers often being borne on leafy side shoots.

63. Ipomoea suburceolata O'Donell (1953: 394). Type: Bolivia, "Caupolican", fide note on sheet at Kew, Pearce 779 (holotype K)

Liana, glabrous in all parts, stems pale brown, woody. Leaves $4-9 \times 4-8 \mathrm{~cm}$, ovate, acute, base cordate to subtruncate, glabrous, abaxially paler, gland-dotted with pale whitish glands. Inflorescence of small cymes, often aggregated into a terminal panicle-like inflorescence; bracts resembling small leaves; peduncles $1.3-2 \mathrm{~cm}$; secondary peduncles $10-15 \mathrm{~mm}$; bracteoles $2-3 \mathrm{~mm}$, oblong-ovate, obtuse, deciduous; pedicels $5-10 \mathrm{~mm}$; sepals reddish, slightly unequal, outer $6-7 \mathrm{~mm}$, ovate, obtuse, inner $8-9 \mathrm{~mm}$, narrowly obovate with scarious margin; corolla $3.5-4 \mathrm{~cm}$, tubular but somewhat inflated in the middle to $10-12 \mathrm{~mm}$, fuchsia-red, limb 5-lobed, 4 - $5 \mathrm{~mm}$ long, dark red; stamens shortly exserted. Capsule $10-12 \times 5 \mathrm{~mm}$, ovoid, style persistent; seeds oblong in outline, c. $5 \times 2 \mathrm{~mm}$, long-pilose. Fig. 24 .

DISTRIBUTION \& HABITAT. Bolivian endemic restricted to dry forest between 750 and $1200 \mathrm{~m}$ in the inter- 
Andean valleys north of Apolo in the Madidi National Park. Map 13.

SPECIMEnS eXamined. BoliviA. La Paz: Prov. Tamayo, Caupolican, R. Pearce 779 (K).; Chaquimayo, 17 km NW of Apolo, near Río Machariapo, $14^{\circ} 34^{\prime} \mathrm{S} 68^{\circ} 28^{\prime} \mathrm{W}$, 1000 m, 10 June 1990, A. Gentry 71078 (MO); 5 km above Hac. Ubito, $14^{\circ} 23^{\prime} \mathrm{S} 68^{\circ} 28^{\prime} \mathrm{W}, 1200 \mathrm{~m}, 19$ July 1993, M. Kessler 4007 (LPB); ANMI Madidi, Asariamas, Río Resina, $14^{\circ} 18^{\prime} 12^{\prime \prime S} 68^{\circ} 32^{\prime} 17^{\prime \prime} \mathrm{W}, 9$ June 2006, L. Cayola 1746 (LPB); PN Madidi, Asariamas, $14^{\circ} 23^{\prime} 25^{\prime \prime S} \quad 68^{\circ} 32^{\prime} 43^{\prime \prime W}, 781 \mathrm{~m}, 2$ July 2013, A. Fuentes 18492 (LPB, MO).

CONSERvation Status. Provisionally assessed as Endangered (EN). For its extent of occurrence this species could be considered to be Critically Endangered but all its recorded populations lie within a protected area which faces no obvious risk of habitat change. Further study to evaluate the number and extent of its different populations would be desirable to confirm its status.

PHENOLOGY. Like Ipomoea schulziana this species flowers during the winter dry season in June and July. NOTES. Very similar to Ipomoea schulziana in habit, leaves and tendency of inflorescence to become paniculate but distinguished by the tubular corollas of a distinct fuchsia colour, the limb reduced to five very short lobes.

64. Ipomoea bonariensis Hook. (Hooker 1839: t. 3665). Type: Cultivated plant grown from seed collected by Tweedie at Buenos Aires (lectotype K 00612912, designated here).

A very variable trailing or, more commonly, twining perennial to at least $3 \mathrm{~m}$ in height, roots tuberous, stems becoming woody when old, sparsely or densely roughly hirsute with stellate hairs. Leaves petiolate, usually $3-9 \times 3-9 \mathrm{~cm}$, ovate, obtuse and mucronate, commonly 3 - 5-lobed to about half way or margin sinuate, adaxially dark-green, asperous, stellatepubescent, abaxially grey, stellate-tomentose; petioles $1-6 \mathrm{~cm}$. Inflorescence of pedunculate, $1-10$-flowered, axillary cymes, sometimes becoming racemose in form; peduncles $2-8 \mathrm{~cm}$, stout, asperous-stellatehirsute; bracteoles scale-like, caducous; secondary peduncles $1-3.5 \mathrm{~cm}$; pedicels $2-10 \mathrm{~mm}$ (very rarely

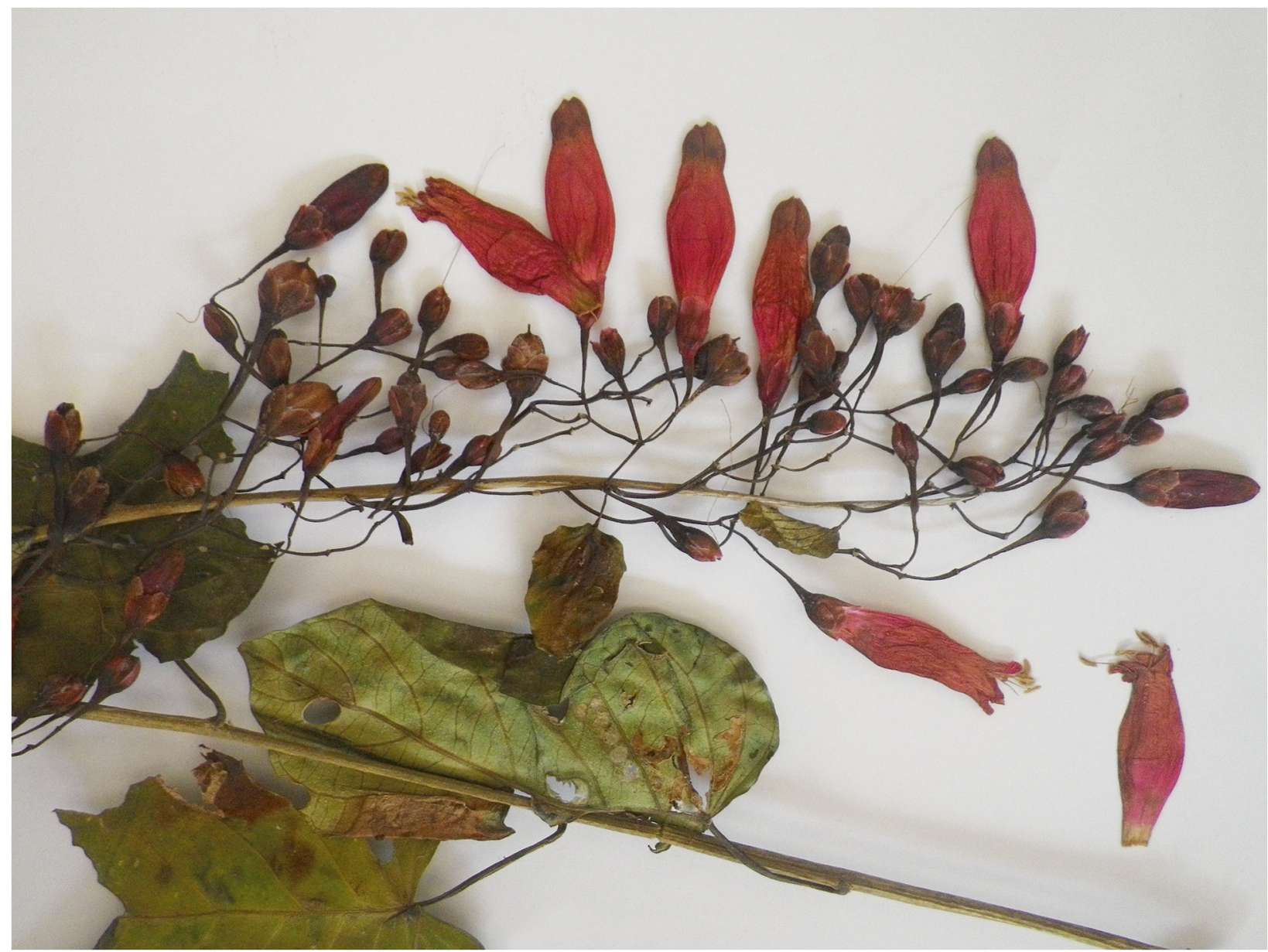

Fig. 24. Herbarium specimen of Ipomoea suburceolata (A. Fuentes 18492) showing distinct suburceolate corolla with shortly exserted stamens 
more); calyx globose, sepals slightly unequal, coriaceous, concave, obtuse, usually glabrous, the margins scarious, outer $5-8 \times 4-5 \mathrm{~mm}$, elliptic, inner slightly broader and longer; corolla $4-7 \mathrm{~cm}$, funnel-shaped, pink, glabrous, limb c. $4 \mathrm{~cm}$ diam., shallowly lobed. Capsule narrowly ovoid, $11-12 \times 7 \mathrm{~mm}$, glabrous, seeds $5-7 \mathrm{~mm}$ long, pilose with hairs $10 \mathrm{~mm}$ long. Fig. 23D.

TYPIFICATION. The plate in Curtis's Botanical Magazine was prepared from a plant grown from seed sent by Tweedie from Buenos Aires. There are two specimens of the cultivated plant from Hooker's herbarium at Kew but neither corresponds closely to the illustration, one being of an immature plant and the other of separate leaves, flowers and cymes mounted on the same sheet. We have designated the latter as lectotype as it is more informative than the immature specimen.

DISTRIBUTION \& HABITAT. Ipomoea bonariensis var. bonariensis appears to be restricted in Bolivia to Santa Cruz Department where it is widespread below about $600 \mathrm{~m}$, showing a very similar distribution to that of $I$. abutiloides and I. argentinica. It is particularly common in the Chiquitania and often found in scrub and forest margins around rock platforms although it is not restricted to this habitat. Its absence from other lowland areas is surprising. Map 14.

SELECTED SPECIMENS OF 27 eXAMINED. BOLIVIA. Santa Cruz: Prov. Germán Busch, a 30 km de Puerto Suárez a Cerro Mutún, $19^{\circ} 11^{\prime} 10^{\prime \prime S} 57^{\circ} 55^{\prime} 22^{\prime \prime S}, 231 \mathrm{~m}, 29$ March 2009, J. R. I. Wood E D. Villarroel 25904 (K, LPB, UB, USZ). Prov. Chiquitos, en la subida a la cumbre de Santiago, $2 \mathrm{~km}$ hacia el valle de Tucavaca, $18^{\circ} 19^{\prime} \mathrm{S}$ $59^{\circ} 34^{\prime} 33 " \mathrm{~W}, 692 \mathrm{~m}, 7$ March 2011, J. R. I. Wood E D D. Soto 27186 (K, LPB, USZ). Prov. Cordillera, PN KaaIya, bifurcación of road Ravelo-Palmar, $18^{\circ} 57^{\prime} 29^{\prime \prime S}$, $60^{\circ} 27^{\prime} 34^{\prime \prime} \mathrm{W}, 250 \mathrm{~m}, 17$ - 18 Feb. 1998, A. Fuentes $\mathcal{E} \mathrm{G} G$. Navarro 2338 (BOLV, LPB, MO, USZ). Prov. Guarayos, $3 \mathrm{~km} \mathrm{~S}$ of Ascención de Guarayos, San Joaquin, $63^{\circ} 06^{\prime} \mathrm{S}, 15^{\circ} 43^{\prime} \mathrm{W}, 250 \mathrm{~m}, 27$ April 1977, A. Krapovickas \& A. Schinini 31877 (CTES). Prov. Ichilo, Buenavista, 450 m, 30 April 1925, J. Steinbach 7098 (BM, K, LIL, MO). Prov. Ñuflo de Chávez, Piedra de Calama, cerca de Concepción, $16^{\circ} 04^{\prime} 40^{\prime \prime} \mathrm{S}$ $61^{\circ} 59^{\prime} 08^{\prime \prime} \mathrm{W}, 484 \mathrm{~m}, 8$ April 2011, J. R. I. Wood 27458 (K, LPB, USZ). Prov. Velasco, on the road from San Ignacio to Vilabela, $15^{\circ} 56^{\prime} 17^{\prime \prime} \mathrm{S} 60^{\circ} 49^{\prime} 58^{\prime \prime} \mathrm{W}, 313 \mathrm{~m}$, 16 April 2013, J. R. I. Wood et al. 27858 (K, LPB, OXF, USZ).

CONSERVATION STATUS. Least Concern (LC).

PHENOLOGY. Ipomoea bonariensis flowers from February to May near the end of the summer rainy season.

NOTE. Ipomoea bonariensis is readily recognised by the stellate hairs which cover all vegetative parts. However, it is very variable in habit, density of the

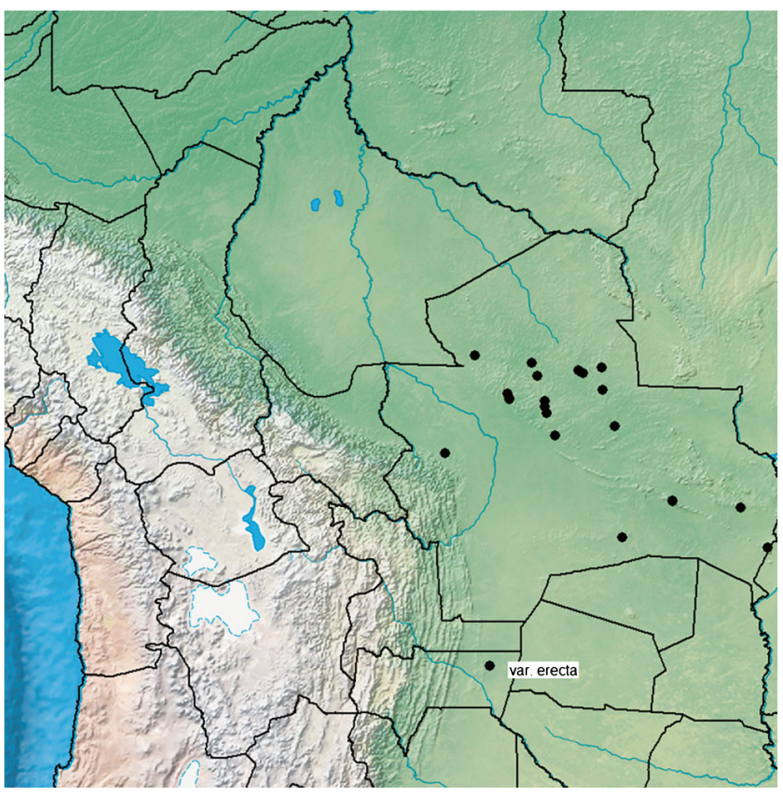

Map 14. Distribution of Ipomoea bonariensis ( $)$, a species in Bolivia characteristic of the Chiquitania; note the isolated station for var. erecta.

indumentum and leaf shape. Many varieties have been described but only one, var. chacoensis O'Donell was accepted by O'Donell (1959b). This is characterised by its deeply 5 - 7-lobed leaves. It is common in the chaco of Paraguay and Argentina but has not yet been found in Bolivia although it might be expected to occur. However the following variety characterised by its erect habit and woody stem is definitely present:

Ipomoea bonariensis var. erecta J. R. I. Wood $\mathcal{E} R$. W. Scotland, var. nov. Type: Paraguay, Nueva Asunción, cerca del cuartel de Gral. Eugenio A. Garay, A. Charpin $\mathcal{E}$ L. Ramella 21528 (holotype G).

http://www.ipni.org/urn:lsid:ipni.org:names:77148131-1

RECOGNITION. Differs from all other forms and varieties of $I$. bonariensis by being an erect undershrub at least $30 \mathrm{~cm}$ high with a woody stem $3-10 \mathrm{~mm}$ thick and a subterminal inflorescence with cymes arising from the uppermost leaf axils. In both specimens of this variety the leaves are shallowly, palmately 5-lobed. Fig. 25.

DISTRIBUTION \& HABITAT. Var. erecta is only known from the Gran Chaco of Tarija Department and nearby Nueva Ascensión in Paraguay. It is a plant of Chaco scrub.

SPECIMENS eXAMINed. BoliviA. Tarija: Prov. Gran Chaco, Mun. Villamontes, Puesto Ganadero La Criollo, 275 m, 30 April 2010, P. Zuñiga et al. 20 (HSB). PARAgUAY. Nueva Asunción, cerca del cuartel de Gral. Eugenio A. Garay, 310 m, 10 May 1988, A. Charpin E L. Ramella $21528(\mathrm{G})$. 
65. Ipomoea oranensis O'Donell (1948: 185). Type: Argentina, Salta, Dep. Orán, San Andrés, Pierotti 280 (holotype LIL!).

Ipomoea santacrucensis O'Donell (1952: 237). Type: Santa Cruz, Camiri, M. Cardenas 4258 (holotype LIL!; isotype US!).

Vigorous twining perennial, stems thinly to densely pubescent with stellate and simple hairs. Leaves petiolate, $4-15$ $\times 2-9 \mathrm{~cm}$, ovate-deltoid (rarely 3-lobed to half way), shortly acuminate and mucronate, base shallowly cordate to truncate and broadly cuneate onto the petiole, adaxially thinly pubescent, abaxially grey-tomentose; petioles $1-7 \mathrm{~cm}$, tomentellous. Inflorescence of lax, axillary, often compound, pedunculate cymes; peduncles $3-11.5$ $\mathrm{cm}$, tomentose; bracteoles $5-10 \mathrm{~mm}$, filiform, tomentose, caducous; secondary peduncles $1.5-2 \mathrm{~cm}$; tertiary peduncles, slightly shorter; pedicels $0.5-2 \mathrm{~cm}$, pubescent to tomentose; sepals coriaceous, somewhat unequal, outer sepals $6-11 \times 5-7 \mathrm{~mm}$, elliptic, obtuse, concave, entirely glabrous or pubescent in the lower half only, margins scarious; inner sepals 7.5 - $12 \mathrm{~mm}$, slightly broader and rounded; corolla $4.5-7 \mathrm{~cm}$, funnel-shaped, pink, glabrous, limb $4-5 \mathrm{~cm}$ diam., shallowly lobed. Capsule $14-15 \times 12-13 \mathrm{~mm}$, suborbicular, glabrous; seeds $7 \times 4$ $\mathrm{mm}$, long-pilose. Fig. 23E.

DISTRIBUTION \& HABITAT. Ipomoea oranensis is common in Bosque Serrano Chaqueño and Tucuman-Bolivian forest between about $650 \mathrm{~m}$ and $2300 \mathrm{~m}$ extending from just south of Santa Cruz through the Departments of Chuquisaca and Tarija to Orán in Argentina, being perhaps most common in Chuquisaca Departament. Its distribution is very similar to that of I. exserta and the two species sometimes grow together but $I$. oranensis is more typical of altitudes above $1600 \mathrm{~m}$. Map 16 .

SELECTED SPECIMENS OF 34 EXAMINED. BOLIVIA. Chuquisaca: Prov. Azurduy, Tarvita, Com. Cuñiripampa, 1944'49"S 64²9'49"W, 2130 m, M. Jiménez Ẽ J. Villalobos 755 (MO, OXF). Prov. Boeto, $0.5 \mathrm{~km}$ de Nuevo Mundo hacia Río Grande, 1859'34"S 64¹7'05"W, 2151 m, 23 March 2004, J. R. I. Wood et al. 20493 (BOLV, HSB, K, LPB). Prov. Luis Calvo, camino entre Ipati - Muyupampa, Serranía del Incahuasi, 1949'24"S 6343'26"W, 1616 m, 25 March 2013, J. R. I. Wood et al. 27639 (LPB, OXF, USZ). Prov. Siles, Mun. Huacareta. Serranía Los Milagros, 20¹9'46"S 6402'32"W,



Fig. 25. Herbarium specimen of Ipomoea bonariensis var. erecta (P. Zuñiga et al. 20), showing woody erect habit and palmately lobed leaves. 
1854 m, 22 Dec. 2005, M. Serrano et al. 6853 (MO, OXF). Prov. Sud Cinti, NE of Com. Arbolito, $21^{\circ} 04^{\prime} 50^{\prime \prime S}$ 64²0'18"W, 1478 m, 3 Feb. 2006, R. Lozano et al. s.n. (NY). Prov. Tomina, $3 \mathrm{~km} \mathrm{~S}$ of Sopachuy, $19^{\circ} 30^{\prime} 50^{\prime \prime S}$, 6428'10'W, 1993 m, 21 March 2004, J. R. I. Wood 20458 (HSB, K, LPB). Prov. Zudañez, on descent to Sacha Pampa c. $11 \mathrm{~km}$ NE of Mojocoya, 18 43'S 64³6'W, $1900 \mathrm{~m}, 22$ March 1998, J. R. I. Wood Eं M. Serrano 13356 (HSB, K, LPB). Santa Cruz: Prov. Cordillera, $5 \mathrm{~km} N$ of Charagua, $19^{\circ} 46^{\prime} \mathrm{S}, 63^{\circ} 12^{\prime} \mathrm{W}, 800 \mathrm{~m}, 13$ April 1990, I. Vargas 474 (NY,

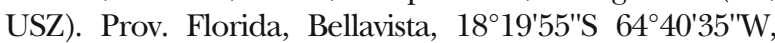
1365 m, 8 April 2006, D. Villarroel et al. 476 (NY). Prov.

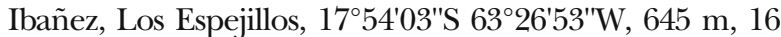
July 2007, G. A. Parada et al. 124 (MO, OXF). Prov. Vallegrande, camino de Loma Larga a Cerro Bocón, 18 48'28"S 6352'55"W, 2085 m, 7 April 2011, G. A. Parada et al. 3191 (USZ). Tarija: Prov. O'Connor, $13.5 \mathrm{~km} \mathrm{~W}$ of Entre Rios on road to Tarija, $21^{\circ} 28^{\prime} 49^{\prime \prime S} 64^{\circ} 12^{\prime} 05^{\prime \prime} \mathrm{W}, 1712$ m, 15 Feb. 2008, M. Mendoza et al. 2860 (K, USZ).

CONSERVATION STATUS. Including its limited presence in Argentina this species has an area of occurrence of almost $52,000 \mathrm{~km}^{2}$ and should be classified as Least Concern (LC) on this basis. It is a common species at the edge of forest and in scrub derived from forest throughout its range in Bolivia as testified by the relatively large number of records. It faces no obvious threat.

PHENOLOGY. Flowers during the summer rains from December to April.

NOTES. O'Donell knew both Ipomoea oranensis and I. santacrucensis from only the type specimens and noted their similarity in indumentum, leaf shape and sepals (O'Donell 1952: 239) but distinguished them mainly on sepal and floral dimensions. With over 30 collections available for study now it is clear that the two species are one and the same. A whole range of dimensions are evident bridging the extremes observed by O'Donell. It should also be noted that both indumentum and leaf shape also vary considerably in this species as in the related I. bonariensis.

Ipomoea oranensis has stellate hairs but they are never obvious as in I. bonariensis and are often difficult to find, most hairs being simple. I. oranensis is very similar to $I$. exserta and indistinguishable when not in flower. However the funnel-shaped corolla is totally different from the hypocrateriform corolla of $I$. exserta with its exserted stamens.

66. Ipomoea exserta J. R. I. Wood $\mathcal{E}^{2} R$. W. Scotland, sp. nov. Type: Bolivia, Chuquisaca, Prov. Luis Calvo, $14 \mathrm{~km}$ E of Monteagudo, on pass before descent to Timboy Pampa, J. R. I. Wood 9693 (holotype HSB; isotypes K, LPB).

http://www.ipni.org/urn:lsid:ipni.org:names:77148132-1

Liana to $6 \mathrm{~m}$, the stems sometimes pendulous from overhanging branches, stems woody below, somewhat wiry above, thinly pilose, glabrescent when old, sometimes leafless when flowering. Leaves petiolate, $6-14 \times 5-10 \mathrm{~cm}$, mostly ovate, sometimes suborbicular, occasionally shallowly 3-lobed or with a single lateral tooth, base cordate to subtruncate with rounded auricles, apex acute, margin entire to obscurely undulate, adaxially dark green, appressed pubescent with long hairs, abaxially grey-mattedtomentose with some stellate hairs mixed with unbranched hairs; petioles relatively short, $3-4 \mathrm{~cm}$, pilose. Inflorescence of compact many-flowered, axillary cymes, often subracemose in form; peduncle $5-11 \mathrm{~cm}$, commonly twisted, shortly pilose; bracteoles oblong, caducous; secondary peduncles 6 - $10 \mathrm{~mm}$, glabrous; pedicels 2-10 mm, glabrous; sepals subequal, $9-$ $11 \times 4-6 \mathrm{~mm}$ obovate-elliptic, coriaceous, concave, glabrous, margins narrow, scarious; outer sepals minutely mucronate; inner sepals slightly wider than the outer, rounded; corolla completely glabrous, 5 - $5.8 \mathrm{~cm}$, hypocrateriform, the basal subcylindrical tube $3.5-3.8 \times 0.5-0.9 \mathrm{~cm}$, brownish, the limb $1.5-2 \mathrm{~cm}$ long, spreading, lobed, dark pink; stamens exserted $5-8 \mathrm{~mm}$, filaments subequal, c. 30 $\mathrm{mm}$, glabrous apart from the pubescent basal part; anthers oblong, $6 \times 2 \mathrm{~mm}$; style glabrous, c. $35 \mathrm{~mm}$ long, shortly exserted, stigma subglobose. ovary conical. Capsule and seeds not seen. Figs 23F, 26.

RECOGNITION. Similar to Ipomoea oranensis in indumentum, leaf shape and sepal form but immediately distinguished by the hypocratiform corolla with a cylindrical tube and exserted genitalia; it is also close to $I$. asplundii but differs by the caducous bracteoles and corolla shape.

DISTRIBUTION \& HABITAT. Scattered in Bosque Serrano Chaqueño from the Santa Cruz area south to the Villamontes area between 400 and $1400 \mathrm{~m}$. Endemic to Bolivia. Map 15.

SPECIMENS eXAMINed. BoliviA. Chuquisaca: Prov. Belisario Boeto, $8 \mathrm{~km} \mathrm{E}$ of Pampa del Tigre, camino a Los Potreros, 1904'57"S, 64¹0'35"W, 1568 m, 24 March 2004 J. R. I. Wood et al. 20543 (K, LPB). Prov. Luis Calvo, $14 \mathrm{~km} \mathrm{E}$ of Monteagudo, on pass before descent to Timboy Pampa, 1400 m, 14 April 1995, J. R. I. Wood 9693 (HSB, K, LPB); $12 \mathrm{~km} \mathrm{NW}$ of Ticucha, $19^{\circ} 34^{\prime} \mathrm{S} 63^{\circ} 54^{\prime} \mathrm{W}, 1250 \mathrm{~m}, 11$ April 2003, J. Gutiérrez et al. 320 (MO, USZ); Serranía de Incahuasi, camino entre Ipati y Muyupampa, 1949'39"S 6343'31"W, 1583 m, J. R. I. Wood et al. 27643 (K, LPB, USZ). Prov. Hernan Siles, on descent to Río Azero, c. $3 \mathrm{~km}$ towards Monteagudo, $1200 \mathrm{~m}, 9$ March 1998, J. R. I. Wood et al. 13308 (K, LPB). Santa Cruz: Prov. Cordillera, c. $2 \mathrm{~km} \mathrm{NE}$ of Tatarenda, on road from Camiri to Abapo, 1000 m, 22 March 2000, J. R. I. Wood 16093 (K, LPB, USZ). Prov. Florida, Com. Bella Vista, $18^{\circ} 18^{\prime} 20^{\prime \prime S} 63^{\circ} 40^{\prime} 50^{\prime \prime} \mathrm{W}, 1320$ - $1350 \mathrm{~m}, 18$ May 2005, L. Arroyo et al. 2868 (USZ); camino hacia el Chorro del 
Fraile, $18^{\circ} 19^{\prime} 55^{\prime \prime S} 64^{\circ} 40^{\prime} 35^{\prime \prime} \mathrm{W}, 1100$ - 1365 m, 8 April 2006, D. Villarroel et al. 476 (MO). Prov. Ibañez, La Angostura, entrando por el Puente colgante, 15 Jan. 2004, M. Mendoza E Eduardo 987 (K, USZ). Tarija: Prov. Gran Chaco, $45 \mathrm{~km}$ from Tarija towards Entre Rios, 2100 m, 4 March 1966, W. J. Badcock 764 (K); 3 km de Palos Blancos towards Tarija, 21 ${ }^{\circ} 24^{\prime} 39$ "S 6348'18"W, 820 m, 12 Feb. 2008, M. Mendoza et al. 2806 (USZ); Pilcomayo Gorge, c. $7 \mathrm{~km} \mathrm{~W}$ of Villamontes, 21ำ13'52"S 63॰33'32"W, 444 m, 24 March 2013, J. R. I.Wood et al. 27595 (K, LPB, USZ).

CONSERVATION STATUS. Using Geocat this species has an area of occurrence of slightly over $41,500^{2} \mathrm{~km}$ and should be provisionally classified as Near Threatened (NT). Additional records are unlikely to extend this area of occurrence significantly but this species, like most other Ipomoea species, is likely to be tolerant of some disturbance. Little is known about the number or size of different populations and a final assessment should await the completion of a detailed study. It is certainly a good deal less common than I. oranensis, with which it sometimes grows.

PHENOLOGY. Flowers in late summer, principally from February to May.

NOTES. Both Ipomoea exserta and I. oranensis have some stellate hairs mixed with unbranched hairs but these are often difficult to see. The two species may sometimes grow together but I. oranensis is found most commonly at higher altitudes, from 1600 to $2200 \mathrm{~m}$ although there are a few records from as low as $650 \mathrm{~m}$.

67. Ipomoea mauritiana Jacq. (Jacquin 1790 [publ. 1791]: 216). Type: plant cultivated in Vienna, probably not preserved.

Ipomoea pedata G. Don (1838: 281). Type: Ecuador, Guayaquil, Ruiz Ẽ Pavon (lectotype MA 814670, designated here, isolectotype MA 814671).

Vigorous creeping or climbing perennial, stems somewhat woody, winged when old, glabrous. Leaves petiolate, $5-14 \times 6-16 \mathrm{~cm}$, 5-lobed to about two thirds, base shallowly cordate to truncate and cuneate onto the petiole, lobes elliptic, narrowed at both ends, apex obtuse, both surfaces glabrous, abaxially paler; petioles $2-6 \mathrm{~cm}$, usually glabrous. Inflorescence of pedunculate axillary, occasionally compound cymes; peduncles $3-13 \mathrm{~cm}$, glabrous or puberulent; bracteoles $6 \mathrm{~mm}$, linear, caducous; secondary peduncles (if present), $5-15 \mathrm{~mm}$; pedicels $5-22 \mathrm{~mm}$, puberulent; calyx subglobose; sepals slightly unequal, elliptic, concave, coriaceous with a very narrow scarious margin, glabrous or puberulent near base, $7-10 \times 5-6$ $\mathrm{mm}$, the outer obtuse, the inner rounded; corolla $5-6$ $\mathrm{cm}$, inflated above a narrow basal tube, pink, glabrous, limb c. $3 \mathrm{~cm}$ diam. Capsule $10-15 \times 6-10 \mathrm{~mm}$, ovoid, glabrous; seeds $6 \mathrm{~mm}$ long, lanate.
DISTRIBUTION \& HABITAT. Pantropical in distribution but preferring the humid tropics in equatorial regions. In Bolivia apparently a rare species of the Pantanal and Amazonian lowlands.

SPECIMENS EXAMINED. BoliviA. Beni: Prov. Iténez, Magdalena al frente de Com. "La Salud", 1247'S 6350'W, 9 Dec. 2004, D. Ibañez 295 (LPB). Pando: Prov. Manuripi, Conquista, 27 March 1956, E. de la Sota 976 (LIL); ibid., Río Madre de Dios, 150 m, 3 Feb. 1983, F. Fernández Casas E̋ A. Susana 8598 (LPB, MO, NY). Santa Gruz: Germán Busch, Puerto Suárez, $13 \mathrm{~km}$ along road to Mutún, 1906'59"S, 5751'11"W, 178 m, 1 Aug. 2007 (fr.), M. Mendoza et al. 2548 (K, USZ). Reported as abundant at Fazenda Vale de Esperança, Jacadigo, near Corumbá (A. Pott et al. 4837) across the border from Puerto Suárez in Brazil.

CONSERVATION StATUS. Not evaluated (NE). A very widespread pantropical species.

PHENOLOGY. It appears to flower in the summer rainy season from December to March.

NOTES. Ipomoea mauritiana is a very variable plant, particularly in the Old World where forms with unlobed leaves are reported. It is somewhat unsatisfactorily distinguished from I. cheirophylla and similar species. It is a plant of humid tropical lowlands and the leaves are larger than in related species and the inflorescence is only sometimes compound.

68. Ipomoea cheirophylla O'Donell (1959b: 141). Type: Argentina, Salta, Dep. Rosario de la Frontera, Las Termas, C. O'Donell 5360 (holotype LIL).

Twining perennial $2-5 \mathrm{~m}$ in height, stems wiry, glabrous or pubescent. Leaves petiolate, $4-6(-10) \times$ $5-7(-10) \mathrm{cm}, 5-7$-lobed to just above the base, base truncate or broadly cordate and cuneate onto the petiole, lobes oblong-elliptic, narrowed at both ends, apex obtuse and mucronate, usually glabrous but pubescent in the Tarija area, petioles $1-4(-8) \mathrm{cm}$. Inflorescence of usually compound, axillary cymes of $1-5$ (-7) flowers; peduncles $2-8 \mathrm{~cm}$, pubescent; bracteoles $2 \mathrm{~mm}$, oblanceolate, caducous; secondary peduncles 1.3 $2.2 \mathrm{~cm}$; pedicels $7-18 \mathrm{~mm}$, pubescent; sepals slightly unequal, elliptic, concave, coriaceous with a very narrow scarious margin, glabrous or puberulent near base, the outer $6-10 \times 3-5 \mathrm{~mm}$, obtuse, inner $5-7 \mathrm{~mm}$ wide, rounded; corolla $4-5 \mathrm{~cm}$, funnel-shaped, pink, glabrous, limb $4 \mathrm{~cm}$ diam., shallowly lobed. Capsule $10 \times 8 \mathrm{~mm}$, ellipsoid to subglobose, glabrous; seeds $5-6 \mathrm{~mm}$ long, dark brown, woolly. Fig. 23B.

DISTRIBUTION \& HABITAT. Scattered in occurrence in northern Argentina, Paraguay, Bolivia and Brazil. In Bolivia Ipomoea cheirophylla is a species of the dry interAndean valleys but also occurs in scattered locations in humid seasonally swampy areas in the Chiquitania and 


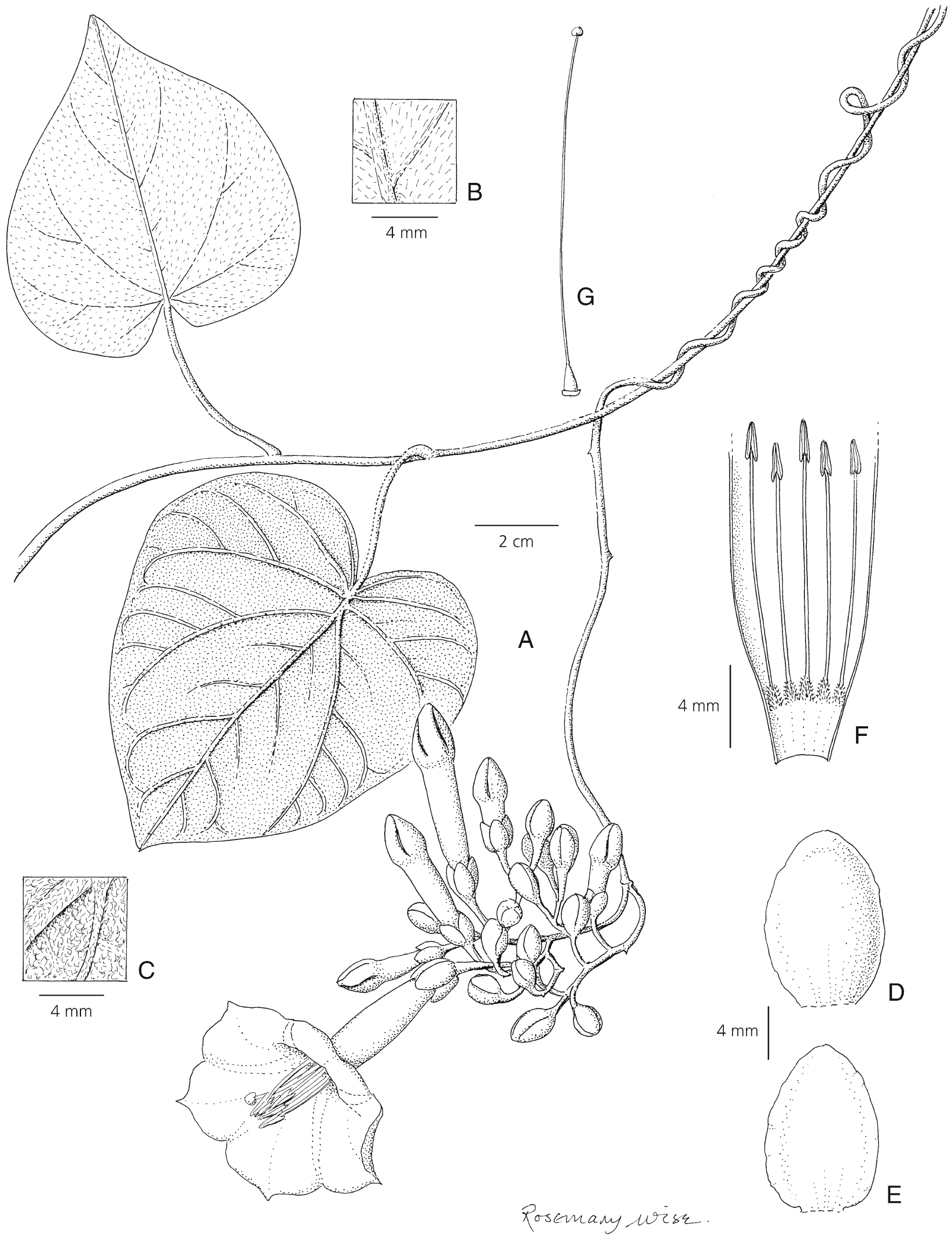

Fig. 26. Ipomoea exserta A habit; B adaxial leaf surface; C abaxial leaf surface; D outer sepal; $\mathbf{E}$ inner sepal; $\mathbf{F}$ corolla opened out to show stamens; G ovary and style. From Wood 16093. DRAWN BY ROSEMARY WISE. 


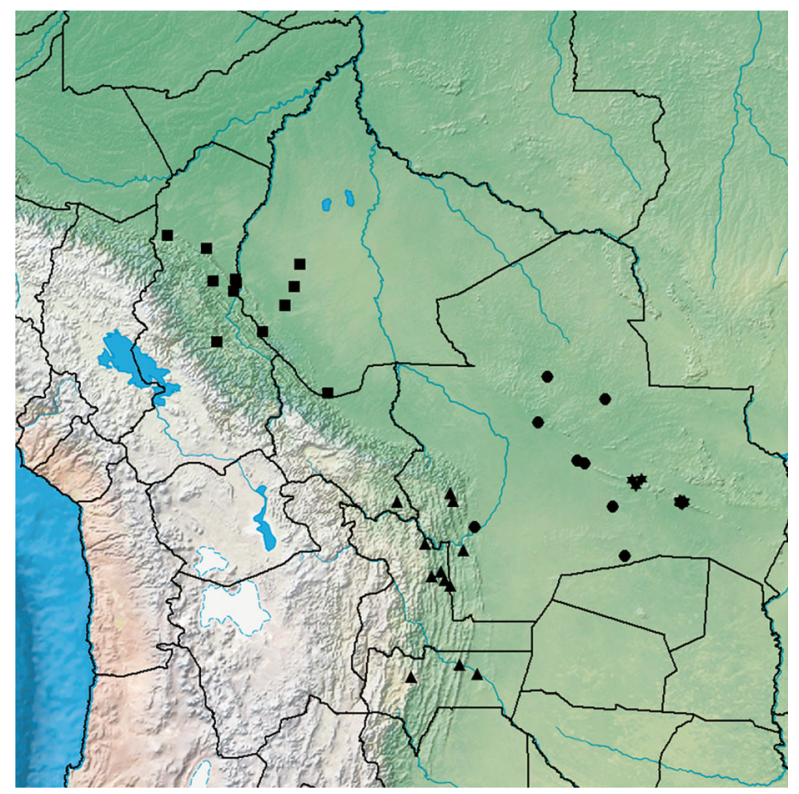

Map 15. Distribution of four relatively widespread endemics: Ipomoea opulifolia $(\square)$ of the Yungas foothills, I. psammophila (*) of cerrado/chaco transition, l. densibracteata ( $)$ of the northern chaco and I. exserta $(\boldsymbol{\Delta})$ of the Tucuman-Bolivian forest region.

the Beni suggesting its ecological requirements are not as distinct from those of I. mauritiana as suggested by O'Donell (1959b: 146).

SELECTED SPECIMENS OF 31 EXAMINED. BOLIVIA. Beni: Prov. Ballivian, Est. Biologica de Beni, 14³0'S 66³7'W, 200 m, 14 Dec. 1994, J. Balderrama 366 (CTES, LPB). Chuquisaca: Prov. Luis Calvo, Iguabaranti, camino La Victoria-Algodonal, 600 m, 31 Jan. 1992, E. Saravia E Nelson 10474 (CTES). Prov. Tomina. Río Tomina Valley c. $1 \mathrm{~km}$ S of Villa Tomina, 19¹1'S 642ㅇ'W, 2100 m, 14 Feb. 1994, J. R. I. Wood 8003 (K, LPB). Prov. Zudañez, bajando a la comunidad de Jacha Pampa del cerro, al este de Mojocoya, 1843'48"S 64³3'03"W, 1605 m, 30 Jan. 2005, J. R. I. Wood Eं H. Huaylla 21548 (HSB, K, LPB). Cochabamba: Prov. Campero, $1 / 2 \mathrm{~km}$ de Aiquile,



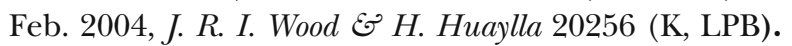
La Paz: Prov. Iturralde, Luisita, $13^{\circ} 05^{\prime} \mathrm{S} 67^{\circ} 15^{\prime} \mathrm{W}, 180$ m, 25 Feb. 1984, S. G. Beck Eं R. Haase 10005 (BOLV, LPB). Santa Cruz: Prov. Caballero, 4 km NW of bridge over Río San Isidro, $18^{\circ} 01^{\prime} \mathrm{S} 6^{\circ} 27^{\prime} 30^{\prime \prime} \mathrm{W}, 1600 \mathrm{~m}, 1$ Jan. 1996, M. Nee 46682 (MO, NY, USZ). Prov. Chiquitos, Quimome, 17²2'19"S 61 ${ }^{\circ} 11^{\prime} 23^{\prime \prime W}, 275$ m, 21 April 2013, J. R. I. Wood Eं B. Williams 27906 (USZ). Prov. Cordillera, Camiri, c. 8.7 km de Cuevo, 20²4'12"S 6327'46"W, 940 m, 9 Feb. 2008, M. Mendoza 2731 (USZ). Prov. Vallegrande, media bajada de Pucará a Santa Rosa del Río Grande, 1841'42"S 64¹7'17"W, 1287 m, 25 Jan. 2005, J. R. I. Wood E M. Mendoza 21488 (K, LPB, USZ). Prov. Velasco, El Refugio, al lado occidental del rio en camino a Toledo, $14^{\circ} 46^{\prime} 18^{\prime \prime} \mathrm{S} 61^{\circ} 02^{\prime} 19^{\prime \prime} \mathrm{W}, 176 \mathrm{~m}$, 21 April 2004, J. R. I. Wood E H. Huaylla 20753 (K, LPB, USZ). Tarija: Prov. Arce, frente a La Capilla, 15 Feb. 1960, T. Meyer 21810 (LIL). Gran Chaco, 5 - 8 km antes de llegar a Palos Blancos sobre el camino Villamontes - Palos Blancos, 21 ${ }^{\circ} 25^{\prime} 20^{\prime \prime S} 63^{\circ} 44^{\prime} 53^{\prime \prime} \mathrm{W}$, 772 m, 24 March 2013, J. R. I. Wood et al. 27616 (K, LPB, USZ). Prov. Tarija, O'Connor, $8 \mathrm{~km}$ de Entre Rios, hacia Palos Blancos, 21 $26^{\prime} 58^{\prime \prime S} 64^{\circ} 04^{\prime} 09^{\prime \prime} \mathrm{W}, 1170 \mathrm{~m}, 16$ Feb. 2008, M. Mendoza 2877 (K, USZ).

CONSERVATION STATUS. Least Concern (LC).

PHENOLOGY. Flowers during the summer rainy season from December to April.

NOTES. Similar to Ipomoea mauritiana but more slender (leaves mostly $<7 \mathrm{~cm}$ long) and inflorescence fewerflowered with longer secondary and tertiary peduncles so the inflorescence appears more lax. The two species are not well separated.

69. Ipomoea caloneura Meisn. (Meisner 1869: 281). Type: Brazil, Goyaz, Burchell 6582 (holotype BR 0000006972875!, isotype K000612845!)

Ipomoea tapirapoanensis Hoehne (1938: 38) Type:

Brazil, Mato Grosso, Tapirapoa[n], F. C. Hoehne 1668 (isotype $\mathrm{R} !$ ).

Trailing or climbing perennial, stems thinly pilose. Leaves petiolate, $2-6 \times 2.5-8 \mathrm{~cm}$, base cordate with rounded auricles, margin somewhat undulate, 3-lobed to about half way, lobes acute to shortly acuminate, central lobe elliptic, narrowed at base, laterals broadly ovate, both surfaces pilose, abaxially paler; petioles $1.5-3 \mathrm{~cm}$, pilose. Inflorescence of mostly $3-5$ flowered axillary cymes, peduncles $3(-11) \mathrm{cm}$, glabrous or thinly pilose; bracteoles linear-lanceolate, 2 - $4 \mathrm{~mm}$; secondary peduncles $1-4.5 \mathrm{~cm}$; pedicels $6-20 \mathrm{~mm}$, glabrous or, rarely, thinly pilose; sepals unequal, coriaceous, concave, glabrous, margins scarious, when fresh pale green, shiny; outer sepals $6-7 \times 4 \mathrm{~mm}$, elliptic, obtuse, inner $10-11 \mathrm{~mm}$, obovate, obtuse; corolla $6-7 \mathrm{~cm}$ long, funnel shaped, pale pink with dark centre, glabrous, limb c. $5 \mathrm{~cm}$ diam., lobed. Capsule $7-8 \times 6 \mathrm{~mm}$, ovoid, glabrous, rostrate; seeds $4-5 \times 2.5 \mathrm{~mm}$ pale brown, glabrous apart from lanate angles with hairs c. $10 \mathrm{~mm}$ long. Fig. 23C.

DISTRIBUTION \& HABITAT. An uncommon plant of the cerrado biome in Bolivia and Brazil. In Bolivia restricted to three granite rock outcrops and one location in cerrado at low altitudes in Velasco province.

SPeCimens examined. BoliviA. Santa Cruz: Prov. Velasco, laja, Las Mechitas, 14 $36^{\prime} 51^{\prime \prime S}, 61^{\circ} 11^{\prime} 51^{\prime \prime}$, 400 m, 24 Jan. 1997, R. Guillén et al. 311 (FTG, LPB, USZ); km 69 sobre el camino de Santa Rosa de la Roca hacia Piso Firme, $15^{\circ} 21^{\prime} 09^{\prime \prime S} 61^{\circ} 29^{\prime} 31^{\prime \prime W}, 295$ m, 6 
April 2011 (fr.), J. R. I. Wood E D. Soto 27430 (K, LPB, USZ); $31 \mathrm{~km}$ N de Santa Rosa de la Roca en el camino a Piso Firme, 1540'42"S 61 $31^{\circ} 36^{\prime \prime} \mathrm{W}, 357 \mathrm{~m}, 18$ Jan. 2014, J. R. I. Wood E D. Soto 27912 (K, LPB, OXF, USZ); Cerro Pelao, km 160 en el camino Santa Rosa a Piso Firme, 14 36'20"S 61 ${ }^{\circ} 29^{\prime} 31^{\prime \prime W}, 180$ m, 20 Jan. 2014, J. R. I. Wood E D. Soto 27916 (K, LPB, OXF, USZ).

CONSERVATION STATUS. With an extent of occurrence of slightly less than $1,900 \mathrm{~km}^{2}$ this species should be classified provisionally as Endangered (EN). Its favoured habitat (rock outcrops) are relatively immune to disturbance and are scattered throughout the region so further populations may be found.

PHENOLOGY. This species flowers at the height of the rainy season in December - February.

NOTES. Very similar to Ipomoea cheirophylla differing in the pilose stem and leaves. The leaves are always 3lobed with much broader segments than in I. cheirophylla and I. mauritiana. The strongly concave, pale shiny green sepals are very distinctive in the field (Fig. 23C).

Species 70 - 75. The Batatas group. Molecular studies support this group as a distinct clade. Morphologically it is characterised by the stiff, chartaceous (papery), mucronate sepals and very shortly pubescent or glabrous seeds but several species including Ipomoea amnicola and $I$. cryptica might be interpreted as belonging when found without mature fruit. The corollas are usually pink with a dark centre or white and the mid-petaline bands often terminate in small teeth. The white-flowered species, I. lactifera, is of particular interest as it represents a newly discovered crop wild relative of the sweet potato. The remaining five species found in Bolivia are ill-defined and have been delimited differently over the years. The following account should be regarded as provisional but, if correct, the reader should be aware that occasional intermediate specimens occur. These may or may not be hybrids but hybridisation is reported to occur within this group (Austin 1978).

70. Ipomoea batatas (L.) Lam. (Lamarck 1793: 465). Convolvulus batatas L. (Linnaeus 1753: 154). Type: India, Herb. Linn. No. 77.5 (S), lectotype designated by Biju 2002: 755).

Creeping perennial herb rooting from the stem and developing root tubers, stems extending to cover several metres, glabrous to coarsely pilose. Leaves petiolate, very variable in form but usually rather large, $3-15 \times 5-12 \mathrm{~cm}$, ovate or shallowly to deeply 3 - 5-lobed, cordate, shortly acuminate, both surfaces glabrous to coarsely pilose, abaxially somewhat glaucous and with prominent veins; petioles usually rather long, $4-15 \mathrm{~cm}$. Inflorescence of long-pedunculate, axillary, dense umbellate cymes; peduncles $5-30 \mathrm{~cm}$ long, stout; bracteoles filiform, c. $2 \mathrm{~mm}$ long, caducous; secondary peduncles $5-15 \mathrm{~mm}$; pedicels very short, $5-$ $10 \mathrm{~mm}$ long; sepals $7-11 \mathrm{~mm}$, unequal, margins often but not always ciliate, outer shorter than inner, oblongelliptic to oblong-oblanceolate, abruptly mucronate with a hair point c. $2 \mathrm{~mm}$ long, prominently $1-5$-veined, the inner sepals broadly elliptic, rounded and mucronate; corolla $4-4.5 \mathrm{~cm}$, pink, often with a dark centre, glabrous; ovary pubescent (rarely glabrous), rarely fertile so capsule and seeds usually absent. Fig. 27A.

DISTRIBUTION \& HABITAT. This species is widely cultivated throughout the tropics but its exact origin is unknown. It is often supposed to have originated in Mexico, although we have seen occasional specimens of apparently wild, fertile plants from various countries in tropical America including Colombia, Panama and Venezuela. In Bolivia Ipomoea batatas is widely cultivated in tropical and subtropical regions, particularly in the Yungas of La Paz and parts of the Beni but more rarely further south and we have no confirmed records of cultivated plants from Tarija and Chuquisaca Departments although it is doubtless cultivated occasionally in these regions. Outside cultivation plants are usually found in derelict fields and on roadsides near cultivation and houses.

SELECTED SPECIMENS OF 34 EXAMINED. BOLIVIA. Beni: Prov. Ballivian, Est. Biologica del Beni, Com. Galilea, 14 30'S 66³7"W, 200 m, 10 May 1995, E. Rivero 43 (LPB, MO). Prov. Cercado, Río Tijamuchi, camino San Ignacio de Moxos, 1451"S 640.'W, 200 m, 1 March 2000, Orellana 839 (LPB). Prov. Vaca Diez, Alto Ivon, $11^{\circ} 45^{\prime} \mathrm{S} 66^{\circ} 02^{\prime} \mathrm{W}$, 200 m, 20 April 1984, B. M. Boom 5122 (NY). Cochabamba: Prov. Carrasco, Yungas de Yana Mayu, Totora, 1800 m, 25 June 1947, M. Cardenas 3957 (F, US). Prov. Chapare, Espiritu Santo, 1891, M. Bang 1290 (NY, US). La Paz: Prov. Iturralde, Caicahuara Tacana, Río Arana, 24 June 1995, A. Serato 69 (MO). Prov. Larecaja, Mapiri, 1600 m, April 1886, H. H. Rusby 1986 (K, NY, P, US). Prov. Murillo, Valle de Zongo, Cahua, 1300 m, 14 June 1980, S. G. Beck 3688 (CTES, CUSCO, FTG, LPB, MO, USZ). Prov. Nor Yungas, Yolosa-Caranavi, entrando por San Pedro de Leon, 950 m, 2 June 1983, S. G. Beck 9205 (LPB, NY, USZ). Prov. Sud Yungas, $6 \mathrm{~km}$ from Chulumani on road to Ocabaya, $16^{\circ} 25^{\prime} 35^{\prime \prime S} 67^{\circ} 33^{\prime} 08^{\prime \prime} \mathrm{W}$, 1765 m, 30 Dec. 2006, S. G. Beck 29716 (LPB). Prov.


Oct. 2010, S. I. Acha 328 (LPB). Santa Cruz: Prov. Cordillera, Curirenda Izozog, 7 Aug. 1998, Roca Ev Vaca 697 (LPB). Prov. Florida, La Yunga de Mairana hacia La Quebrada, $18^{\circ} 05^{\prime} 42^{\prime \prime S} 63^{\circ} 54^{\prime} 55^{\prime \prime W}, 1950$ m, 29 June 1996, I. G. Vargas 4633 (F, MO, NY, USZ). Prov. Guarayos, Com. El Puente between San Ramón and Asención de Guarayos, 16²19'57"S 6254'35"W, 221 m, 

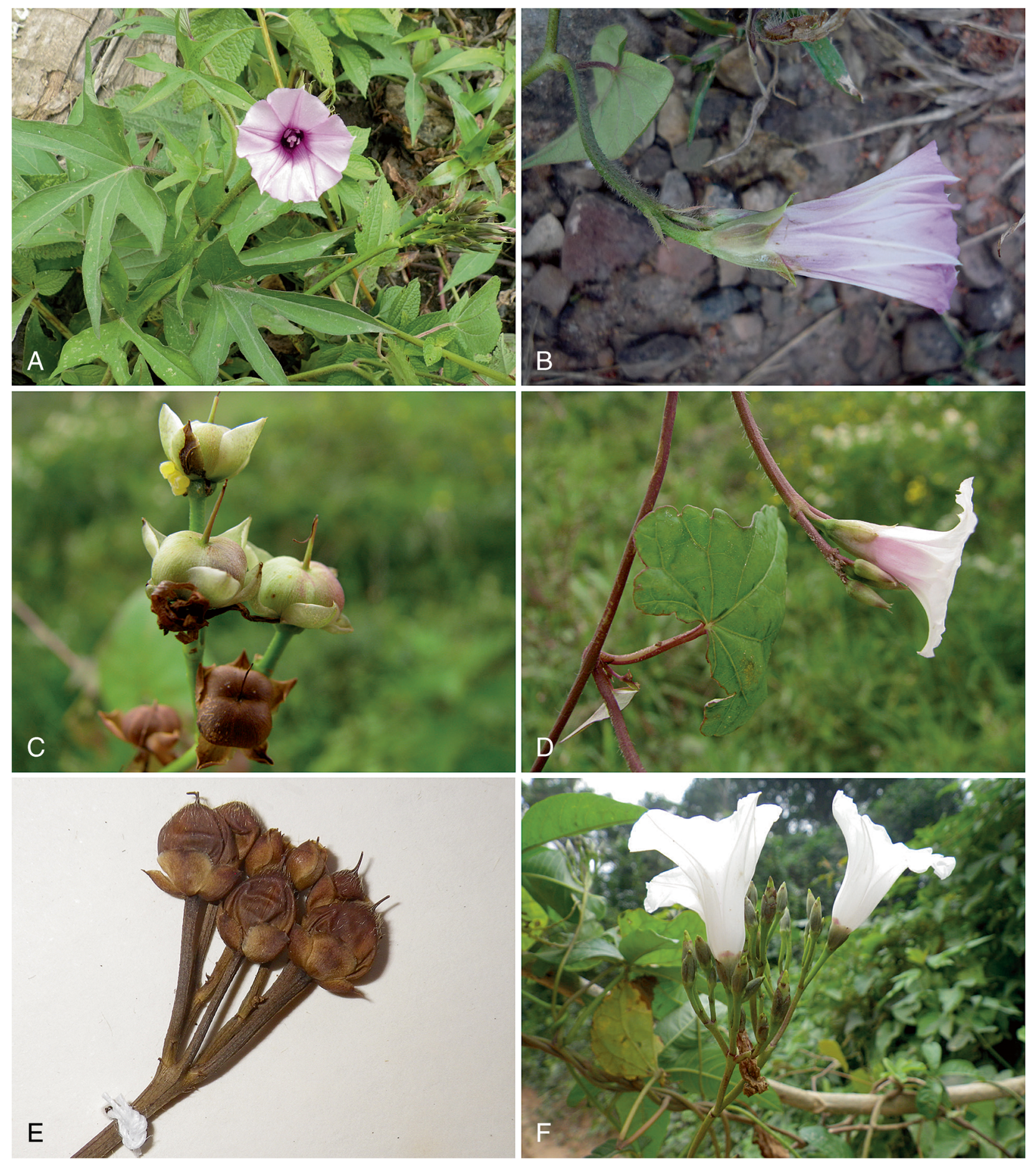

Fig. 27. A Ipomoea batatas; B I. cordatotriloba; C, D I. ramosissima; E I. cynanchifolia; F I. lactifera. PHOTOS: A, E - F JOHN woOD; B BETH WILLIAMS; C - D DANIEL SOTO.

23 July 2014, J. R. I. Wood E D. Soto 27935 (USZ). Prov. Ibañez, city of Santa Cruz $17^{\circ} 47^{\prime} \mathrm{S} 63^{\circ} 12^{\prime} \mathrm{W}, 420 \mathrm{~m}, 17$ Jan. 1989, M. Nee 37607 (LPB, MO, NY). Prov. Ichilo, Buenavista, 450 m, 6 April 1925, J. Steinbach 7042 (BM). Prov. Nuflo de Chávez, Concepción town, $16^{\circ} 08^{\prime} 14^{\prime \prime S}$ $62^{\circ} 01^{\prime} 29^{\prime \prime} \mathrm{W}, 488 \mathrm{~m}, 24$ July 2014, J. R. I. Wood E D D. Soto
27939 (K, LPB, OXF, USZ). Prov. Velasco, TCO Bajo Paraguá, Com. Porvenir, 193 m, 12 June 2005, Hajdu 17 (USZ).

CONSERVATION Status. Not evaluated (NE). Most records are of cultivated plants or escapes from cultivation. 
PHENOLOGY. It has been found in flower throughout the year.

NOTES. Although it is not possible to distinguish cultivated from escaped populations from the cited records there are a number of surprising inferences from the list. In the first place there are no collections from the south of the country. This may indicate that Ipomoea batatas is rarely grown there or simply that botanists have not collected it, something which is surely the case in Inquisivi Province in La Paz and Moxos and other provinces in the Beni. Another curiosity is that many of the vouchers are old, perhaps suggesting I. batatas was more widely cultivated in the past than it is today. Plants are usually readily identified in the field because of their root tubers and perennial creeping habit, the stems rooting at the nodes. Herbarium specimens are distinguished by the strongly and usually abruptly mucronate sepals with a distinct hair point and a pronounced central vein with $2-4$ less prominent lateral veins. The sepals are usually ciliate and the flowers characteristically clustered at the apex of a long peduncle. Most specimens collected in Bolivia have 3-lobed leaves.

71. Ipomoea cordatotriloba Dennst. (Dennstedt 1810: 246). Type as for Convolvulus carolinus L.

Convolvulus carolinus L. (Linnaeus 1753: 154). Type: Icon. in Dillenius, Hortus Elthamensis t. 84 f. 98 (1732), designated by Staples in Staples \& Jarvis (2006: 1020), non Ipomoea carolina (L.) Pursh.

Ipomoea carolina (L.) Pursh., nom. illeg., non Ipomoea carolina L. (1753).

Ipomoea trichocarpa Elliot (1817: 258). Type as for Convolvulus carolinus L.

Slender twining (occasionally trailing) annual herb, stems to $3 \mathrm{~m}$, glabrous, thinly pilose with long white hairs or densely pubescent. Leaves petiolate, $2.5-8 \times$ $1.5-6 \mathrm{~cm}$, ovate-deltoid, or shallowly 3-lobed, narrowly cordate with rounded, entire or dentate auricles, apex shortly acuminate, mucronate, glabrous or thinly pilose on veins and margins or pubescent; petioles $0.5-5 \mathrm{~cm}$. Inflorescence of axillary, pedunculate, umbelliform cymes, usually with $1-5(-9)$ flowers and more lax than in Ipomoea batatas; peduncles $2-9 \mathrm{~cm}$; bracteoles $5-7 \mathrm{~mm}$, filiform, pilose, relatively persistent; pedicels $4-9 \mathrm{~mm}$; sepals subequal, usually ciliate with stiff spreading hairs, occasionally glabrous, outer sepals $8-11 \mathrm{~mm}$, ovate, gradually narrowed to an outwardly curved fine point, the central vein usually distinct, inner sepals $10-12 \mathrm{~mm}$, obovate, abruptly or gradually narrowed to a mucronate apex, less hairy; corolla $2.5-4 \mathrm{~cm}$, gradually widened from base, pink with a dark centre, glabrous, limb c. $2.5 \mathrm{~cm}$ diam., unlobed. Capsule subglobose, $7-8 \mathrm{~mm}$, pilose; seeds brown, hemispherical, $3.5 \mathrm{~mm}$ long, glabrous. Fig. 27B.
DISTRIBUTION \& HABITAT. As generally interpreted this species is amphitropical in the Americas, being found in the United States and Mexico in the northern hemisphere while in the southern hemisphere it is found in Argentina, Paraguay, Bolivia and Brazil, in the last of which it is apparently rare and perhaps limited to Mato Grosso do Sul from where we have seen a handful of specimens, for example, A. Pott et al. 2929 (MBM) from Fazenda Nhumirim, Corumba, $18^{\circ} 59^{\prime} \mathrm{S} 56^{\circ} 39^{\prime} \mathrm{N}$. In Bolivia it is common around Santa Cruz but sporadic and uncommon elsewhere but found in the Yungas as well as the Chaco. It is a lowland species not usually found above $1000 \mathrm{~m}$.

Selected SPECIMENS OF 30 eXAMINed. BOLIVIA. La Paz: Prov. Sud Yungas, bajada de Chulumani a Asunta, comunidad de Zona Esperanza, mas abajo de Villa Barrientos, 16 $10^{\circ} 36^{\prime \prime S} 67^{\circ} 14^{\prime} 16^{\prime \prime} \mathrm{W}, 1009$ m, 2 April 2004, J. R. I. Wood et al. 20610 (BOLV, K, LPB, USZ). Santa Cruz: Prov. Germán Busch, $28 \mathrm{~km}$ al sur del porton de la misión del Rincón del Tigre, $18^{\circ} 23^{\prime} 52^{\prime \prime S} 58^{\circ} 20^{\prime} 01^{\prime \prime} \mathrm{W}, 458 \mathrm{~m}, 28$ April 2008, J. $R$. I. Wood et al. 24581 (K, LPB, UB, USZ). Prov. Chiquitos, Valle de Tucuvaca, aprox. $30 \mathrm{~km}$ de Santiago hacia Santo Corazón, $18^{\circ} 08^{\prime} 11^{\prime \prime S} 59^{\circ} 17^{\prime} 17^{\prime \prime W}$, 11 Oct. 2007, J. R. I. Wood et al. 23473 (K, LPB, UB, USZ). Prov. Cordillera, carretera entre Boyuibe y Camiri, 20²4'02"S 6319'06"W, 904 m, 19 March 2013, J. R. I. Wood et al. 27629 (LPB, OXF, USZ). Prov. Florida, c. 1 km Oeste de Los Negros camino a Pampa Grande, $18^{\circ} 04^{\prime} \mathrm{S}$


(K, LPB, USZ). Prov. Ibañez, third ring, West of University campus, $17^{\circ} 46^{\prime} \mathrm{S} 63^{\circ} 11^{\prime} \mathrm{W}, 420 \mathrm{~m}, 18$ April 1998, M. Nee 49030 (NY, USZ). Prov. Ichilo, Buenavista, 450 m, 6 April 1925, J. Steinbach 7042 (GH, K). Prov. Ñuflo de Chávez, exit of San Antonio de Lomerío towards Concepción, $16^{\circ} 45^{\prime} 52^{\prime \prime S} 61^{\circ} 48^{\prime} 34^{\prime \prime} \mathrm{W}, 376 \mathrm{~m}, 11$ April 2013, J. R. I. Wood 27756 (K, LPB, USZ). Prov. Sara, c. $4 \mathrm{~km} \mathrm{~W}$ of La Bélgica on road to Caranda at edge of settled area, $17^{\circ} 34^{\prime} \mathrm{S} 63^{\circ} 18^{\prime} \mathrm{W}, 300 \mathrm{~m}, 27 \mathrm{Nov} .2005, J$. R. I. Wood 22120 (K, LPB). Prov. Velasco, 10 km del Carmen Ruiz, en el camino a San José de Campamento,

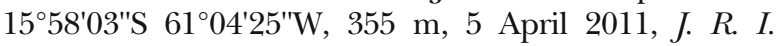
Wood E D. Soto 27413 (K, LPB, USZ). Tarija: Prov. Arce, Emboruzu, 850 m, 15 May 1978, M. Coro 1174 (LIL). Prov. Gran Chaco, $19 \mathrm{~km}$ N of Camatindi on road to Boyuibe, 2050'27"S 6321'24"W, 528 m, 29 March 2006, M. Dematteis et al. 1949 (CTES, GH).

CONSERVATION STATUS. Least Concern (LC).

PHENOLOGY. Flowers at the end of the rainy season from February to July.

NOTES. A very variable species in indumentum, leaf shape, shape of outer sepals and corolla length. The sepals are commonly ciliate.

Wood et al. 27611 (K, LPB, USZ) from Villamontes, Gran Chaco, appears to be Ipomoea cordatotriloba but the ovary and capsule are glabrous. 
Specimens from South America have been treated as a var. australis O'Donell but in the uncertain taxonomic status of all taxa in this group it seems premature to recognise this.

72. Ipomoea grandifolia (Dammer) O'Donell (1952: 222). Jacquemontia grandifolia Dammer (1897: 41). Type: Brazil, Rio de Janiero, Glaziou 11257 (holotype $\mathrm{B} \dagger$, isotypes $\mathrm{C}, \mathrm{K}$ !).

This is distinguished from Ipomoea cordatotrilobata by the shorter corolla $(1.5-2.5 \mathrm{~cm}$ long).

DISTRIBUTION \& HABITAT. Ipomoea grandifolia is apparently frequent in NE Argentina, Paraguay and much of eastern Brazil whereas I. cordatotriloba, which also occurs in North America, is mostly found in the Andean foothills of Argentina and Bolivia but extends into Paraguay. There are few certain records from Bolivia, all from the eastern lowlands where it grows on disturbed grassy roadsides at low altitudes

SPECIMENS eXAMINed. BOlIVIA. Cochabamba: Prov. Carrasco: al lado del reten de Ivirgazama, $17^{\circ} 01^{\prime} 47^{\prime \prime S}$ 6452'51"W, 247 m, 4 April 2013, J. R. I. Wood E B. Williams 27733 (K, LPB, USZ). Chuquisaca: Prov. Luis Calvo, La Pista, 20³4'20"S 63⒋'15"W, 700 m, 26 March 1992, E. Saravia 10851 (HSB). Santa Cruz: Prov. Nuflo de Chávez, c. $1 \mathrm{~km}$ from centre of San Javier along road towards Concepción, 16 16 33"S 62²8'55"W, 553 m, 25 July 2014, J. R. I. Wood Eं D. Soto 27943 (K, LPB, OXF, USZ); between Los Troncos and Río Grande crossing to Okinawa, $17^{\circ} 05^{\prime} 51^{\prime \prime S} 62^{\circ} 40^{\prime} 45^{\prime \prime} \mathrm{W}, 258 \mathrm{~m}, 26$ July 2014, J. R. I. Wood Ẽ D. Soto 27949 (K, LPB, OXF, USZ).

PHENOLOGY. Flowers at the end of the rainy season from February to July.

CONSERVATION STATUS. Not evaluated (NE) because of its uncertain taxonomic status.

NOTES. Ipomoea grandifolia was a forgotten species misplaced in Jacquemontia until it was transferred into Ipomoea and rediagnosed by O'Donell (1952: 226 - 228). Comparing his summary of its characteristics in 1952 with that in his posthumous account of Ipomoea in Argentina (1959b) O'Donell had clearly come to depend on flower size alone to distinguish I. grandifolia, rather than any of the secondary characters discussed in 1952. However, flower size is scarcely a satisfactory character given the range of variation in corolla size within I. cordatotriloba. Examination of the surviving isotype of Ipomoea grandifolia at Kew shows a plant with a corolla 2 $2.2 \mathrm{~cm}$ long and narrowly ovate outer sepals which taper to a mucronate apex. This is a near perfect match for Wood E Williams 27733 from Ivirgazama in Cochabamba Department. Unfortunately the narrower sepals are no more convincing as a character than the corolla size as many specimens of $I$. cordatotriloba have similar sepals, rather than the more usual ovate, more abruptly mucronate sepals often found in that species.

Ipomoea grandifolia appears to be a small-flowered variant of $I$. cordatotriloba with no distinct ecology. In the greenhouses of the International Potato Centre in Lima, there are numerous living plants of both species grown from collections from Paraguay, Argentina and Bolivia. These show a baffling range of corolla size and capsule indumentum and supposed differences between the species are totally unconvincing.

Ipomoea grandifolia is also very close to the widespread I. triloba L., which is absent from South America according to Austin (1978) and Austin \& Huáman (1996), although widely distributed as a weed in the Old World. Austin (1978: 120) claims I. grandifolia is a hybrid but only suggests I. cordatotriloba as one parent. Perhaps it has arisen as a result of hybridisation with an introduced $I$. triloba resulting in offspring showing a range of corolla sizes, sepal shape and indumentum that bridges the two species. This problem is only likely to be resolved by detailed molecular studies using a very large sample.

73. Ipomoea ramosissima (Poir.) Choisy (1845: 377). Convolvulus cymosus Ruiz \& Pavon (1799: 9), non Desr. (Desrousseaux 1796). Type: Peru, Huánuco, Ruiz $\mathcal{E} \sigma^{2}$ Pavon s.n. (lectotype MA 814677, designated here; isolectotypes F, MA814678, MA814675, MA 814676, OXF).

Convolvulus ramosissimus Poir. (Poiret 1813 [publ. 1814]: 468).

Ipomoea dichotoma Choisy (1845: 383), nom. illeg., non I. dichotoma Kunth (1819). Type: Brazil, Lund 319 (holotype G00135826!).

Slender twining annual herb, usually nearly glabrous in all parts but occasionally stems thinly pilose. Leaves petiolate, mostly $3-5.5 \times 2-4.5 \mathrm{~cm}$, ovate or shallowly 3-lobed, cordate with rounded to obtuse auricles, apex shortly acuminate, mucronate, glabrous or adaxially with a few hairs; petioles $1.5-5 \mathrm{~cm}$, glabrous or thinly pubescent. Inflorescence of long pedunculate axillary umbelliform cymes with $2-5$ flowers; peduncles $2-$ $10 \mathrm{~cm}$; bracteoles tiny, triangular, caducous; pedicels $5-$ $15 \mathrm{~mm}$; sepals subequal, oblong-obovate with broad scarious margins, rounded and mucronate, glabrous or with a few marginal cilia, outer sepals $3.5-6 \mathrm{~mm}$, inner sepals c. $1 \mathrm{~mm}$ longer; corolla $1.5-2.5 \mathrm{~cm}$, funnel-shaped, pink with a dark centre, glabrous, limb $1.5-1.75 \mathrm{~cm}$ diam., unlobed or shallowly lobed, sometimes dentate. Capsule $2-$ $3 \times 4 \mathrm{~mm}$, depressed-subglobose, enclosed by sepals, glabrous, the slender style somewhat persistent; seeds $3 \times$ $2.5 \mathrm{~mm}$, ellipsoid, dark brown, glabrous or pilose on the angles. Fig. 27C, D. 
DISTRIBUTION \& HABITAT. Widely distributed in tropical America south to Argentina. In Bolivia it is common in the tropical lowlands perhaps favouring areas with good rainfall but with a distinct dry season as there are no records from Pando or the Chapare. It grows on forest margins, in forest relics and and in disturbed places around settlements, often appearing on wire fences. It is usually found in the lowlands below $500 \mathrm{~m}$ but reaches at least $1600 \mathrm{~m}$ in the La Paz Yungas.

CONFIRMED SPECIMENS EXAMINED. BOLIVIA. sin. loc., M. Bang 2246 (E, F, GH, K, MO, NY). Beni: Prov. Ballivian, Isla de Taita, Est. Biológica del Beni, 14³0'S 66³0'W, 280 m, 16 Nov. 1990, M. Lewis 38011 (ARIZ). Prov. Cercado, $5 \mathrm{~km}$ de Trinidad hacia Santa Cruz, $14^{\circ} 57^{\prime} \mathrm{S} 64^{\circ} 44^{\prime} \mathrm{W}, 50 \mathrm{~m}$, 23 July 1992, Rueda 860 (USZ). Prov. Yacuma, Est. Biológica del Beni, 1450'S 66 30'W, 250 m, 2 Sept. 1991, T. Killeen E Palacios 3441 (ARIZ, BOLV, MO, USZ). La Paz: Prov. Caranavi, 1545'S 67³5'W, 7 June 1996, R. K. Brummitt $\mathcal{E} D$. Wasshausen 19437 (K, US). Prov. Nor Yungas, Alto Beni, carretera del Puente Sapecho a Boopi, 450 m, 26 May 1988, R. Seidel 2457 (ARIZ, K, LPB). Prov. Sud Yungas, Evenay, Asunta, Río Bopi, 31 July 1939, B. Krukoff 10692 (F, GH, K, MO); Chulumani, 1600 m, 22 June 1950, W. M. A. Brooke 6528 (BM); $3 \mathrm{~km} \mathrm{~N}$ of Chulumani on road to Asunta, $16^{\circ} 22^{\prime} \mathrm{S} 68^{\circ} 30^{\prime} \mathrm{W}, 1600$ m, 10 July 1994, J. R. I. Wood 8607 (K, LPB). Prov. Tamayo, ANMI Madidi, Asariamas, Río Resina, $14^{\circ} 18^{\prime} 50^{\prime \prime} \mathrm{S}, 68^{\circ} 32^{\prime} 28^{\prime \prime} \mathrm{W}, 721 \mathrm{~m}, 8$ June 2005, L. Cayola 1743 (LPB, MO). Santa Cruz: Prov. Guarayos, camino Ascención a Urubicha, $15^{\circ} 35^{\prime} \mathrm{S}$ 6302'W, 3 Aug. 1983. M. Hopkins et al. s.n. (LPB); c. $1 \mathrm{~km}$ from Ascención along road to La Chonta by an abandoned sawmill, 15 53'36"S 63¹0'10"W, 234 m, 23 July 2014, J. R. I.Wood E D. Soto 27933 (K, LPB, OXF, USZ). Prov. Ibañez, Angostura to Bermejo, $18^{\circ} 10^{\prime} \mathrm{S}$ $63^{\circ} 31^{\prime} \mathrm{W}, 700,2$ Aug. 2006, D. Villarroel 764 (LPB, USZ); Los Espejillos, $17^{\circ} 52^{\prime} 21^{\prime \prime S} 63^{\circ} 26^{\prime} 47^{\prime \prime W}, 500$ m, 25 July 2007, G. A. Parada et al. 195 (MO, OXF, USZ). Prov. Ichilo, Buenavista, $450 \mathrm{~m}, 10 \mathrm{July}$ 1925, J. Steinbach 7165 (BM, E, F, K, NY); c. $6 \mathrm{~km}$ from Buenavista along road to Caranda, $17^{\circ} 29^{\prime} 28^{\prime \prime S}$ 6336'50"W, 342 m, 27 July 2014, J. R. I. Wood E D $D$. Soto 27957 (K, LPB, OXF, USZ). Prov. Nuflo de Chávez, $14 \mathrm{~km}$ ENE of Colonia Okinawa 1 on road to Los Troncos, $17^{\circ} 11^{\prime} \mathrm{S} 62^{\circ} 46^{\prime} \mathrm{W}, 250 \mathrm{~m}, 14$ July 1991 , M. Nee 41765 (ARIZ); Aguas Calientes, c. $13 \mathrm{~km} \mathrm{~N}$ of San Javier, 500 m, 24 July 2000, J. R. I. Wood 16500 (K, LPB, USZ); at edge of airfield, Concepción, $16^{\circ} 08^{\prime} 17^{\prime \prime S}$ $62^{\circ} 01^{\prime} 37^{\prime \prime W}, 488 \mathrm{~m}$, 24 July 2014, J. R. I. Wood Eं D. Soto 27937 (K, LPB, OXF, USZ); c. 30 - $35 \mathrm{~km}$ from Concepción along road to San Javier, 16 $14^{\circ} 16^{\prime \prime S}$ $62^{\circ} 15^{\prime} 20^{\prime \prime} \mathrm{W}, 523 \mathrm{~m}, 25$ July 2014, J. R. I. Wood E D. Soto 27942 (K, LPB, OXF, USZ); c. $4 \mathrm{~km} \mathrm{~N}$ of San Javier along road towards Los Tumbos, $16^{\circ} 14^{\prime} 50^{\prime \prime S}$ $62^{\circ} 31^{\prime} 58^{\prime \prime W}, 484$ m, 25 July 2014, J. R. I. Wood Eं D. Soto 27945 (K, LPB, OXF, USZ). Prov. Santiesteban, on W side of Río Grande crossing on road from Okinawa to Los Troncos, $17^{\circ} 10^{\prime} 24^{\prime \prime S} 62^{\circ} 47^{\prime} 17^{\prime \prime W}, 267 \mathrm{~m}, 26$ July 2014, J. R. I. Wood E D. Soto 27950 (LPB, OXF, USZ). Prov. Velasco, $27 \mathrm{~km}$ from San Ignacio hacia San Matías, $16^{\circ} 19^{\prime} 01^{\prime \prime S} 60^{\circ} 45^{\prime} 11^{\prime \prime W}, 360 \mathrm{~m}, 17$ Sept. 2006, M. Mendoza $\mathcal{E}^{2}$ R. M. Ledezma 2227 (USZ). CONSERVATION STATUS. Least Concern (LC).

PHENOLOGY. Flowers during the winter dry season mainly from June to September, much later than other species in this group.

NOTES. Ipomoea ramosissima can only be safely separated from I. cynanchifolia when in fruit. The ripe capsule is always glabrous and distinctly depressed (Fig. 27C). Only specimens confidently identified as I. ramosissima are listed above. There remains a considerable residue of non-fruiting specimens from Bolivia which could be either I. cynanchifolia or I. ramosissima.

74. Ipomoea cynanchifolia Meisn. (Meisner 1869: 274). Type: Brazil, Minas Gerais, Lagoa Santa, Warming (lectotype BR, flowering portion on sheet, designated by O'Donell (1952: 218), isolectotype P).

Slender twining annual herb, nearly glabrous in all parts. Leaves petiolate, mostly $3-5.5 \times 2-4.5 \mathrm{~cm}$, ovate or shallowly 3-lobed, cordate with rounded to obtuse auricles, apex shortly acuminate, mucronate, adaxially thinly pubescent or glabrous; petioles $1.5-5 \mathrm{~cm}$. Inflorescence of long pedunculate axillary umbelliform cymes with $2-5$ flowers; peduncles $2-10 \mathrm{~cm}$; bracteoles tiny, triangular, caducous; pedicels $5-15 \mathrm{~mm}$; sepals subequal, oblong-obovate with broad scarious margins, rounded and mucronate, usually glabrous but occasionally ciliate; outer sepals $3.5-6 \mathrm{~mm}$; inner sepals c. $1 \mathrm{~mm}$ longer; corolla $1.5-2.5 \mathrm{~cm}$, funnel-shaped, pink with a dark centre, glabrous, limb $1.5-1.75 \mathrm{~cm}$ diam., unlobed, sometimes dentate. Capsule $2-3 \times 4 \mathrm{~mm}$, ovoid, exceeding sepals, glabrous or thinly pilose, the slender style somewhat persistent; seeds $3-3.5 \times 2.5 \mathrm{~mm}$, ellipsoid, dark brown, glabrous. Fig. 27E.

DISTRIBUTION \& HABITAT. This species is known from scattered locations in Brazil, Guyana and Bolivia but may be under-recorded. In Bolivia it is plant of the cerrado biome and is restricted to Santa Cruz Department below $700 \mathrm{~m}$, where it grows in disturbed places usually near settlements or around rock outcrops.

SPECIMEnS eXAMINed. BoliviA. Santa Cruz: Prov. Ángel Sandoval, $51 \mathrm{~km} \mathrm{~S}$ of Las Petas sobre el camino a Candelaria, $16^{\circ} 43^{\prime} 06^{\prime \prime S} 59^{\circ} 00^{\prime} 12^{\prime \prime} \mathrm{W}, 120 \mathrm{~m}, 12$ May 2008, J. R. I.Wood et al. 24871 (K, LPB, UB, USZ); Prov. Guarayos, San Joaquin, $3 \mathrm{~km} \mathrm{~S}$ of Ascensión de Guarayos, $15^{\circ} 43^{\prime} \mathrm{S} 63^{\circ} 06^{\prime} \mathrm{W}, 250 \mathrm{~m}, 27$ April 1977, A. Krapovickas $\mathcal{E}^{\circ}$ A. Schinini 31876 (CTES); Ascención de Guarayos en camino a San Ramón, 1 km 
before Est. San Fernando, 16 $01^{\prime} 41^{\prime \prime S} 63^{\circ} 05^{\prime} 37^{\prime \prime} \mathrm{W}, 14$ Sept. 2006, M. Mendoza et al. 2146 (K, USZ). Prov. Ibañez, Angostura, Santa Cruz, 29 June 1966, R. Steinbach 328 (MICH, NY). Prov. Ichilo, Reserva El Choré, 16²6'54"S, 64²13'53"W, 200 m, 19 July 2005, G. A. Parada et al. 22 (MO, OXF, USZ). Prov. Nuflo de Chávez, salida de Concepción sobre la avenida doble via, $16^{\circ} 08^{\prime} 51^{\prime \prime S} 62^{\circ} 01^{\prime} 20^{\prime \prime} \mathrm{W}, 506 \mathrm{~m}, 5$ April 2008, J. $R$. I.Wood et al. 24117 (K, LPB, UB, USZ); c. $25 \mathrm{~km}$ from Concepción along road to San Javier, 16 13'06"S $62^{\circ} 12^{\prime} 45^{\prime \prime W}, 581 \mathrm{~m}, 25$ July 2014, J. R. I. Wood $\mathcal{E} D$. Soto 27941 (USZ). Prov. Velasco, Cerro Pelao, 14³2'S 61 32'W, 400 m, 25 March 1994, E. Ramos et al. 3 (MO); Reserva Forestal Bajo Paraguá, Cerro Diamentina, $14^{\circ} 35^{\prime} 21^{\prime \prime S} 61^{\circ} 29^{\prime} 33^{\prime \prime W}, 350 \mathrm{~m}, 13$ May 1994, T. Killeen E J. Wellens 6343 (ARIZ, LPB, MO, USZ); $650 \mathrm{~km} \mathrm{NE} \mathrm{Santa} \mathrm{Cruz,} 14^{\circ} 45^{\prime} \mathrm{S} 62^{\circ} 00^{\prime} \mathrm{W}$, 700 m, 15 June 1995, L. Sánchez 140 (LPB, USZ); $125 \mathrm{~km}$ N of Santa Rosa de la Roca towards Piso Firme, 1440'29"S 61³0'40"W, 237 m, J. R. I. Wood E $H$. Huaylla 20786 (HSB, K, LP); 5 km N de San Miguel en camino a San Ignacio, 16 ${ }^{\circ} 39^{\prime} \mathrm{S} 59^{\circ} 19^{\prime} 10^{\prime \prime} \mathrm{W}, 447 \mathrm{~m}, 8$ April 2008, J. R. I. Wood et al. 24284 (K, LPB, UB, USZ); $69 \mathrm{~km}$ N of Santa Rosa de la Roca towards Piso Firme, 15²15'34"S 61 ${ }^{\circ} 29^{\prime} 56^{\prime \prime} \mathrm{W}, 231 \mathrm{~m}, 24$ April 2009, J. R. I. Wood et al. 26113 (K, LPB, USZ); 6 km de Santa Rosa de la Roca hacia Concepción, 1553'22"S 61³1'19"W, 390 m, 30 April 2012, J. R. I.Wood E D. Soto 27533 (K, LPB, USZ); Prov. Warnes, Las Barreras, 21 June 1980, 375 m, F. E. Tollervey 2519 (K).

CONSERVATION STATUS. Least Concern (LC).

PHENOLOGY. Flowers at the end of the summer rainy season from about March to July.

NOTES. Ipomoea cynanchifolia is very close to I. ramosissima and is only safely separable when good fruit is available. It is distinguished by the thinly pilose (rarely glabrous) ovoid capsules which are clearly visible above the fruiting calyx (Fig. 27E). The shape of the fruiting capsule is the decisive character as the capsule indumentum is not constant in sect. Batatas. No secondary characters are reliable but it is noteworthy that most specimens cited above and by O'Donell (1952: 218) flower in the March May period, much earlier than I. ramosissima, the later collections cited above, Mendoza et al. 2146, Parada et al. 22 and Wood E' Soto 27941 are fruiting specimens with a single corolla.

75. Ipomoea lactifera $J . R . I$. Wood $\mathcal{E}$ R. W. Scotland, sp. nov. Type: Bolivia, Santa Cruz, Prov. Ichilo, $2-20 \mathrm{~km}$ from Buenavista along road to El Huaytu, J. R. I. Wood $\mathcal{E}^{2}$ D. Soto 27954 (holotype USZ; isotypes K, LPB, OXF).

http://www.ipni.org/urn:lsid:ipni.org:names:77148133-1

Perennial twining herb of unknown height, latex white, stem glabrous. Leaves petiolate, $5-9 \times 3.3-7 \mathrm{~cm}$, ovate, base cordate and very broadly cuneate onto the petioles, auricles rounded, apex acuminate to a shortly mucronate apex, margin entire, glabrous except for an area of puberulence on veins and margin at base around point of insertion of petiole; petiole $2.2-6.8$ $\mathrm{cm}$, glabrous but thinly puberulent upwards. Inflorescence of long pedunculate, many-flowered, axillary cymes; peduncles $5-10 \mathrm{~cm}$, glabrous, secondary peduncles $1.5-3 \mathrm{~cm}$, bracteoles $1 \times 1 \mathrm{~mm}$, suborbicular, early caducous leaving a prominent basal scar, pedicels $8-14 \mathrm{~mm}$, glabrous to slightly farinose; sepals glabrous or somewhat farinose, unequal, somewhat papery in texture, the margins slightly scarious but not conspicuously pale, outer 5 $6.5 \times 2.5-3 \mathrm{~mm}$, oblong-obovate, rounded, the central vein prominent, slightly raised and terminating in a mucro, inner $7-8.5 \times 5 \mathrm{~mm}$, elliptic, rounded, minutely mucronulate with the mucro deciduous; corolla $3-4 \mathrm{~cm}$, broadly funnel-shaped and gradually widened from base, limb $2-2.5 \mathrm{~cm}$ diam., white or very pale pink with darker centre, glabrous; filaments glabrous except at base, longer $11-13 \mathrm{~mm}$, shorter $5-6 \mathrm{~mm}$, anthers c. $3 \mathrm{~mm}$ long, oblong, ovary glabrous; style 17 - $20 \mathrm{~mm}$ long, stigma obscurely 2lobed. Capsule and seeds not seen. Figs 27F, 28.

RECOGNITION. This species was originally identified as Ipomoea splendor-sylvae House from Mesoamerica and molecular studies confirm its placement in the Batatas group of species. From all other species in this group it can be distinguished by its perennial habit, glabrous leaves and large white corolla. The only other species in this group with white flowers are slender weedy annuals from ruderal habitats, these usually hirsute and with smaller flowers and unreported from Bolivia. I. lactifera is unlikely to be confused with any species in Bolivia except I. squamosa and I cryptica. From both of these it can be distingusished by its white corolla and by the sepals that lack the conspicuous white margins of those two species.

DISTRIBUTION \& HABITAT. This endemic species is characteristic of humid forest or forest relics on the Andean foothills or Beni plain being found between 200 and $1000 \mathrm{~m}$.

SPECIMENS EXAMINED. BoliviA. Beni: Prov. Ballivián, Río Beni, one hour upstream from Rurrenabague, $14^{\circ} 30^{\prime} \mathrm{S} 67^{\circ} 29^{\prime} \mathrm{W}, 320 \mathrm{~m}, 26$ May 1990, D. C. Daly et al. 6639 (FTG); Bajío, along Río Viejo, 1450'S 6605'W, 15 Sept. 1993, R. Chávez de Michel E゚ S. G. Beck 1152 (K, LPB); Est. Biologica del Beni, Puerto Mendez, canchón de Germán Caity, 14³0'S 66³7'W, 23 Aug. 1994, G. Caity 149 (K, LPB, OXF); Prov. Cercado, $0.5 \mathrm{~km}$ N del Puerto Almacen-Mirador, 240 m, 29 Aug. 1991, F. de la Puente 3593 (CIP de Lima). Cochabamba: Prov. Chapare, El Choclotal, Río Espiritu Santo, c. $20 \mathrm{~km}$ above Villa Tunari, $17^{\circ} 00^{\prime} \mathrm{S}$ 653' 'W, 500 m, 4 Oct. 2007, J. R. I. Wood 23411 (K, 
LPB, USZ). Santa Cruz: Prov. Ichilo, PN Amboró, c. one hour by trail along Río Cheyo, opposite Estancia Huaytu, 173' S, 63 $40^{\prime} \mathrm{W}, 400$ m, 24 Aug. 1985, J. C. Solomon 14004 (K, LPB, MO); 2 - $20 \mathrm{~km}$ from Buenavista along road to El Huaytu, 17 46'28"S 6339'11"W, 348 m, 27 July 2014, J. R. I. Wood E D D. Soto 27954 (K, LPB, OXF, USZ).

CONSERVATION StATUS. Data Deficient (DD). The extent of occurrence of this species suggests a classification of Least Concern (LC) but there are few records. The species may well have been overlooked and any firm classification is premature.

PHENOLOGY. A winter flowering species found in flower from July to October.

ETYMOLOGY. This species is named "lactifera" because of the copious white latex which appears to be feature of the plant.

NOTES. The discovery of Ipomoea lactifera is of exceptional interest as it is an additional crop wild relative of the sweet potato. Apart from I. batatas itself it is the only perennial species of this group growing in Bolivia and the first with an exclusively Andean distribution.

76. Ipomoea cryptica J. R. I. Wood $\mathcal{E} R$. W. Scotland, sp. nov. Type: Bolivia, Dep. Santa Cruz, Prov. Ichilo, 2 $10 \mathrm{~km}$ from Buenavista along road to Huaytu, J. R. I. Wood E D. Soto 27955 (holotype USZ; isotypes K, LPB, OXF).

http://www.ipni.org/urn:lsid:ipni.org:names:77148134-1

Twining perennial or liana to $5 \mathrm{~m}$, stems glabrous. Leaves petiolate, ovate-deltoid, mostly $4-10 \times 2-7.5 \mathrm{~cm}$, base broadly cordate to subhastate, the auricles usually acute, sometimes rounded, apex acuminate to an obtuse and mucronate apex, both surfaces glabrous; petiole $1-5 \mathrm{~cm}$, glabrous. Inflorescence of rather dense, 3 - 15-flowered, axillary, pedunculate cymes; peduncles 5 - $12 \mathrm{~cm}$, glabrous; bracteoles ovate, acute, c. $2 \mathrm{~mm}$ long, caducous; secondary peduncles and pedicels short, $5-8(-13) \mathrm{mm}$, glabrous; sepals very unequal, glabrous, outer $1-3 \mathrm{~mm}$ long, suborbicular to elliptic, the margins scarious, inner $7-8 \mathrm{~mm}$, broadly elliptic, rounded, margins broad, scarious; corolla $3.5-6 \mathrm{~cm}$, glabrous, funnel-shaped, tube lilac, limb unlobed, $3.5-4 \mathrm{~cm}$ diam., pink; filaments glabrous except at base, longer $11 \mathrm{~mm}$, shorter 7 - $8 \mathrm{~mm}$; anthers c. $4 \mathrm{~mm}$ long, oblong; ovary glabrous; style c. $15 \mathrm{~mm}$ long, stigma obscurely 2-lobed. Capsule and seeds not seen. Figs 29, 30A.

RECOGNITION. This species is very similar to Ipomoea squamosa and I. anisomeres B. L. Rob. \& Bartlett and was treated under the latter name in Wood et al. (2015) but molecular studies indicate there is no close relationship. However, like both these species I. cryptica has a congested, many-flowered inflorescence and sepals with distinct scarious margins. From I. squamosa it is best separated by the very short outer sepal (2 - $3 \mathrm{~mm}$ long) and the completely glabrous stem, petioles and leaves - I. squamosa is usually at least thinly pubescent at the base or near the margins of the leaves in South American specimens. From I. anisomeres it is best distinguished by the much shorter pink corollas. I. cryptica sometimes grows with I. lactifera in the Buenavista area of Ichilo Province but is readily separated by the pink corolla and very unequal sepals with conspicuous scarious margins.

DISTRIBUTION \& HABITAT. We can only confirm the presence of Ipomoea cryptica in Bolivia but it is highly likely that it also occurs in Brazil - Krukoff 4582 (BM, NY) from the Rio Juruá (Yarúa) near Independencia in Amazonas State appears to be this species as does Spruce 1702 from "Amazonas" (det. as ipomoea sp. aff. squamosa at $\mathrm{K}$ by $\mathrm{J}$. A. McDonald). In Bolivia it is a species of lowland forest, forest relics and drainage dykes in areas cleared of forest below $650 \mathrm{~m}$ in the Departments of Beni, La Paz and Santa Cruz. At present it is impossible to confirm its frequency because of inadequate collecting and confusion with I. squamosa. It is only recently that we have become aware of its distinction as a result of molecular studies.

SPECIMENS eXAmined. BoliviA. Beni: Prov. Cercado, Laguna Limonsin, 1454'32"S, 64²6'54"W, 29 June 2010, D. Soto et al. 1331 (OXF, USZ). Prov. Marban, Casarabe, Aug. 1988, F. de la Puente 3572 (CIP de Lima, FTG). Prov. Moxos, camino San Ignacio de Moxos a Santa Ana de Yacuma, 1455'54"S, 65 $42^{\prime} 22^{\circ} \mathrm{W}, 158 \mathrm{~m}, 26$ Aug. 2009, G. A. Parada et al. 1537 (MO, OXF, USZ); Laguna Mauso, $10 \mathrm{~km}$ SW of San Ignacio de Moxos, $15^{\circ} 00^{\prime} 38^{\prime \prime S}, 65^{\circ} 43^{\prime} 09^{\prime \prime} \mathrm{W}, 17$ July 2010, D. Soto et al. 1487 (USZ). La Paz: Prov. Larecaja, Guanai, c. 650 m, May 1886, H. Rusby 1987 (BM, K, MICH, NY, P, US). Santa Cruz: Prov. Ichilo, Río Surutú, 450 m, 2 Aug. 1924 J. Steinbach 6311 (A, K); 2 - $10 \mathrm{~km}$ from Buenavista along road to Huaytu, 17²8'57"S 6339'15"W, 345 m, 27 July 2014, J. R. I. Wood E D. Soto 27955 (K, LPB, OXF, USZ). Prov. Santiesteban, between Montero and Okinawa, $17^{\circ} 17^{\prime} 02^{\prime \prime S} 63^{\circ} 09^{\prime} 20^{\prime \prime} \mathrm{W}, 275 \mathrm{~m}$, 26 July 2014, J. R. I. Wood E D. Soto 27952 (K, LPB, OXF, USZ). Prov. Sara, by road from Buenavista to Portachuelo, near turn to Santa Rosa de Sara, 27 July 2014, J. R. I. Wood Eं D. Soto 27961 (K, LPB, OXF, USZ).

CONSERVATION STATUS. Not evaluated (NE) because of taxonomic uncertainty. Based on its apparent extent of occurrence in Bolivia it might be considered Least Concern (LC) but it is premature to make any formal decision of its status.

PHENOLOGY. A winter flowering species found in flower from May to August. 


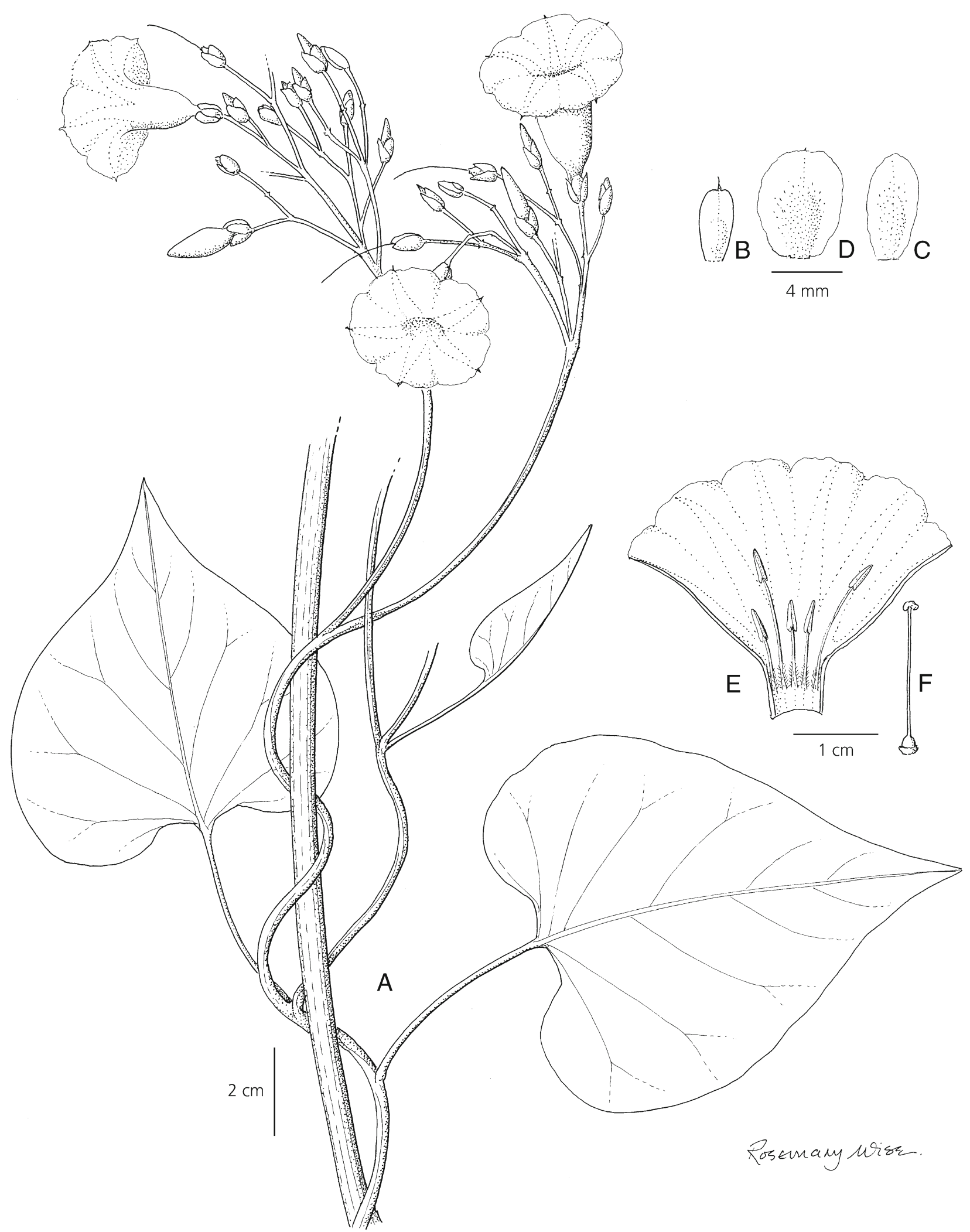

Fig. 28. Ipomoea lactifera. A habit; B outer sepal; C middle sepal; D inner sepal; E corolla opened out to show stamens; F ovary and style. From Solomon 14004. DRAWN BY ROSEMARY WISE. 


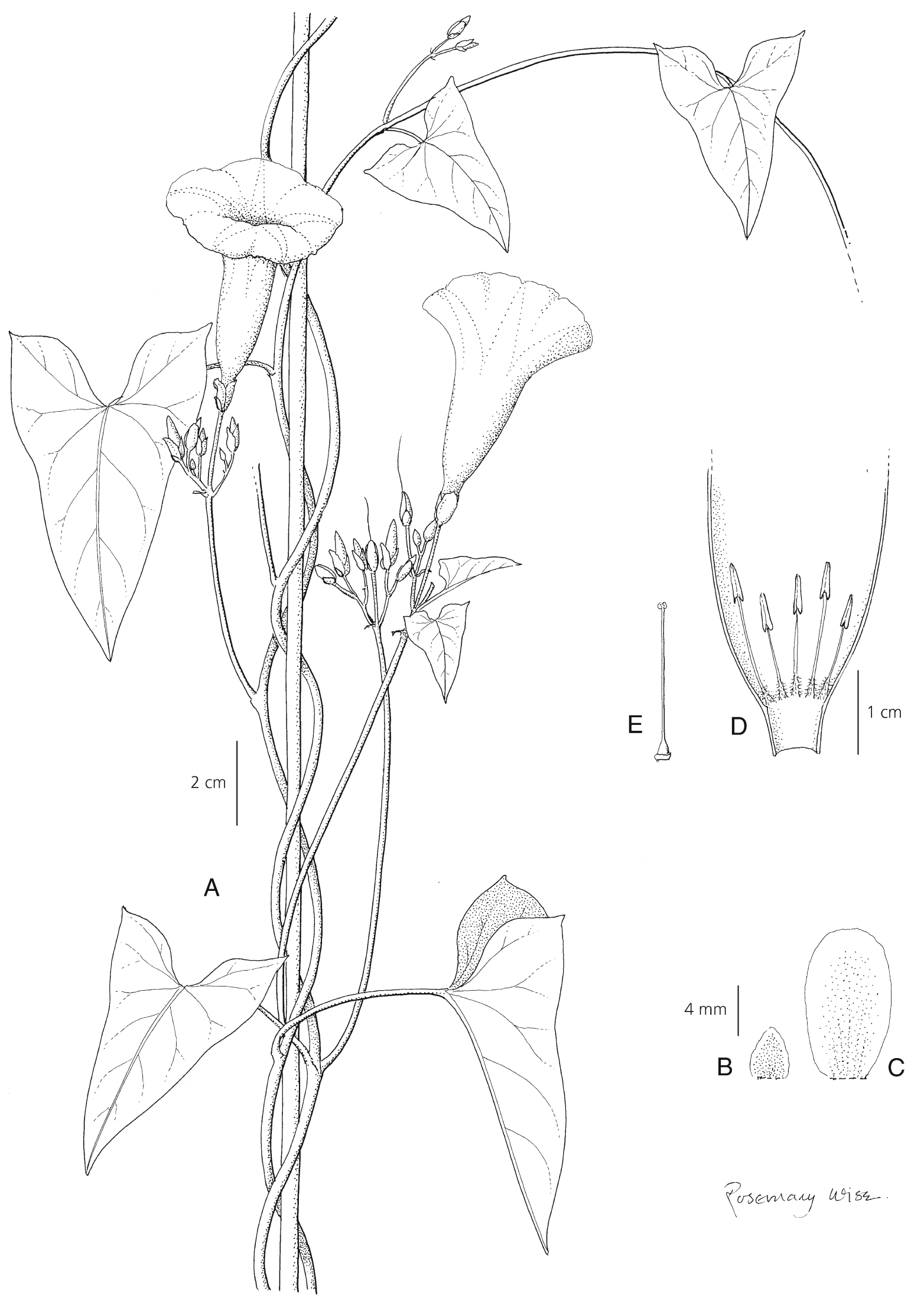

Fig. 29. Ipomoea cryptica A habit; B outer sepal; C inner sepal; D corolla opened out to show stamens; E ovary and style. From Parada et al. 1537. DRAWN BY ROSEMARY WISE. 

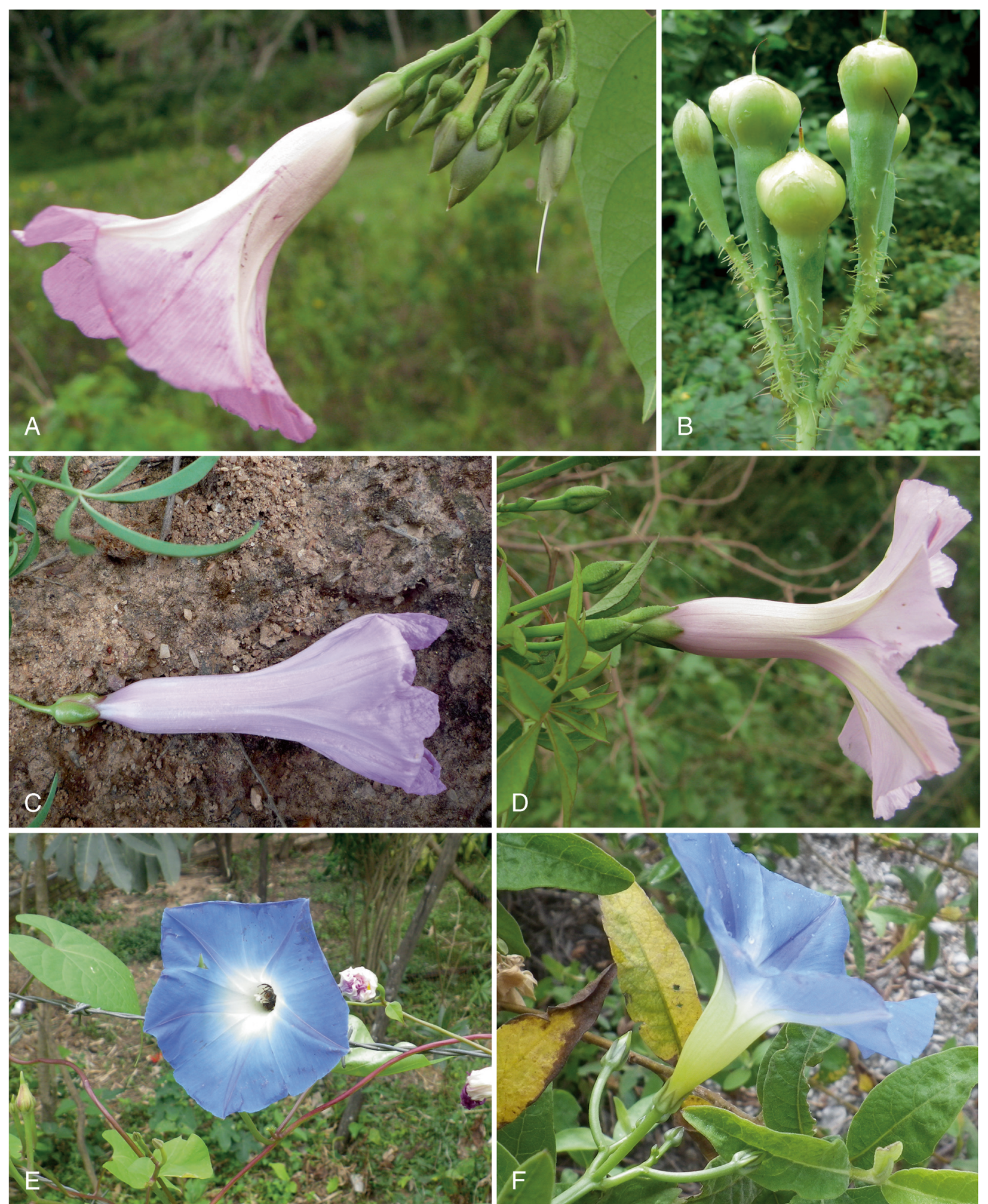

Fig. 30. A Ipomoea cryptica; B I. setosa; C I. graniticola; D I. cairica; E I. tricolor; F I. marginisepala. PHOTOS: A, D - E DANIEL SOTO; B C, F BETH WILLIAMS.

ETYMOLOGY. The epithet "cryptica" refers to the cryptic characters by which the specis is defined.
NOTES. We have not been able to trace the origin of the record of Ipomoea anisomeres in Austin \& Huáman 
(1996) but it was perhaps an error for this species. There is no evidence that I. anisomeres occurs in Bolivia.

77. Ipomoea setosa Ker-Gawl. (Ker Gawler 1818: 335). Type: Ker Gawler, Bot. Reg. 4: t. 335, designated by A. Mcdonald (1994: 110).

Ipomoea pavonii Choisy (1845: 390). Type: Ecuador, Guayaquil, Pavon s.n. (holotype G n.v.; isotypes MA814625, MA814626, MA814627).

Calonyction pavonii Hallier (1897: 1048).

Ipomoea setosa var. pavonii (Choisy) House (1908: 220). Ipomoea horrida Huber ex Ducke (1959: 304). Type:

Brazil, Ceará, Ducke 1151 (holotype MG, isotype F).

Scrambling perennial herb, stems with soft fleshy spines and bluish-green bloom but otherwise glabrous. Leaves petiolate, $10-32 \times 10-32 \mathrm{~cm}$, mostly 3-lobed to about halfway but sometimes ovate-orbicular, apex shortly acuminate, obtuse and mucronate, base cordate with rounded auricles, margin irregularly dentate with scattered teeth, both surfaces glabrous; petioles 5 $14 \mathrm{~cm}$, armed with soft fleshy spines. Flowers in longpedunculate axillary cymes; peduncles $5-15 \mathrm{~cm}$, armed with soft fleshy spines; bracteoles $5-10 \times 2$ $\mathrm{mm}$, oblong, mucronate, caducous; secondary peduncles $1.5-3 \mathrm{~cm}$; pedicels $1-4 \mathrm{~cm}$, markedly thickened upwards, armed with soft fleshy spines below, glabrous upwards, often purplish-brown; sepals subequal, 8 $10 \mathrm{~mm}$ at anthesis (accrescent to $16 \mathrm{~mm}$ in fruit), ovate, acute, concave, glabrous (or in central America with soft fleshy spines), purplish-brown with scarious margins; corolla $4-5(-6) \mathrm{cm}$ long, funnel-shaped, pink, glabrous, limb c. $2.5 \mathrm{~cm}$ diam. Capsule subglobose, $15 \mathrm{~mm}$ long, glabrous; seeds $7 \times 5 \mathrm{~mm}$, woolly, nearly black. Fig. 30B.

DISTRIBUTION \& HABITAT. Widely distributed but scattered and never common throughout tropical America north to Mexico. Possibly not native in Bolivia but well naturalised in a few locations around the fringes of the Chaco, where it grows in disturbed bushy country.

SPECIMENS EXAMINed. BOLIVIA. Chuquisaca: Prov. Tomina, between Thiu Mayo and Puente Azero, on Sucre-Monteagudo road, $19^{\circ} 35^{\prime} \mathrm{S} 64^{\circ} 05^{\prime} \mathrm{W}, 1400 \mathrm{~m}, 10$ April 1994, J. R. I.Wood 8283 (K, LPB); ibid., 19³6'32"S 64 05'27"W, 1133 m, 26 March 2013, J. R. I. Wood et al. 27649 (K, LPB, USZ). Santa Cruz: Prov. Cordillera, Lagunillas $19^{\circ} 45^{\prime} \mathrm{S} 63^{\circ} 40^{\prime} \mathrm{W}, 950 \mathrm{~m}, 15$ April 1977, A. Krapovickas $\mathcal{E}^{\circ}$ A. Schinini 31364 (CTES, LIL). Prov. Florida, outskirts of Mairana along road to Villa Ecce Homo, 1807'30"S, 635' 1300 m, 2 Jan. 1998, M. Nee 47760 (LPB, NY, USZ). Prov. Ñuflo de Chávez, Las Trancas, $16^{\circ} 31^{\prime} 13 " \mathrm{~S} 61^{\circ} 50^{\prime} 47^{\prime \prime} \mathrm{W}, 450 \mathrm{~m}, 13$ June 1995, F. Mamani 774A (USZ). Prov. Vallegrande, camino Algodonal a Masicurí, 1900'36"S 6341'49"W, 542 m, 6 April 2011, G. A. Parada et al. 3149 (USZ). Tarija: Prov. Gran Chaco, Villamontes, 460 m, 25 Feb. 1925, Pflanz 4145 (US).

CONSERVATION STATUS. On the basis of its extent of occupancy this species is of Least Concern (LC). However populations are few and small (here as elsewhere in South America) and further studies are needed to confirm its status.

PHENOLOGY. An annual species flowering mainly towards the end of the rainy season from February to June.

NOTES. Bolivian specimens of Ipomoea setosa and all those we have seen from South America except from Ecuador differ from the lectotype in having glabrous sepals. They always have 3-lobed leaves and the corolla is relatively small, being $4-7 \mathrm{~cm}$ long. The name I. setosa var. pavonii can be used for these. Specimens seen from Ecuador and Costa Rica are similar to the type while those from Mexico are very different in appearance having sepals densely covered in soft spines, a large corolla up to $10 \mathrm{~cm}$ long and 5-lobed leaves.

78. Ipomoea cairica (L.) Sweet (1826: 287).

Convolvulus cairicus L. (Linnaeus 1759: 922). Type: "Convolvulus Aegyptius" Vesling in Alpinio, $\mathrm{Pl}$. Aegypti 73 - 74 (1640), designated by Bosser \& Heine (2000).

Twining perennial herb to $3 \mathrm{~m}$, stems glabrous, often muricate. Leaves petiolate, digitately divided into $5-7$ leaflets, the laterals sometimes joined at base, leaflets $1-5 \times 0.3-1 \mathrm{~cm}$, lanceolate or oblonglanceolate, acute and mucronate, glabrous; petioles with stipule-like outgrowths at base, $1-5 \mathrm{~cm}$. Flowers usually solitary, sometimes in shortly pedunculate, 2 -3flowered axillary cymes; peduncles $0.3-1 \mathrm{~cm}$; bracteoles $1-2 \mathrm{~mm}$, oblong, caducous; pedicels $0.3-2.5 \mathrm{~cm}$; sepals subequal, glabrous with scarious margins, outer $5-7 \times$ $4 \mathrm{~mm}$ oblong-ovate, acute, inner $6-8 \mathrm{~mm}$, broadly ovate-elliptic, obtuse; corolla $4.5-7 \mathrm{~cm}$, funnel-shaped, pink, glabrous, limb $4 \mathrm{~cm}$ diam., unlobed. Capsule $1-1.3$ $\mathrm{cm}$, subglobose, glabrous; seeds $5-6 \mathrm{~mm}$, tomentellous with longer caducous marginal hairs. Fig. 30D.

DISTRIBUTION \& HABITAT. A pantropical species, probably of Old World origin, now widespread throughout tropical and subtropical regions. Introduced into Bolivia and sometimes cultivated on fences around houses but also well-naturalised in waste places, usually near settlements, up to $2600 \mathrm{~m}$. It is most frequently collected in the Andean region and around Santa Cruz.

SELECTED SPECIMENS OF 16 EXAMINED. BOLIVIA. Cochabamba: Prov. Mizque, Near Thagathaga on road 
from Mizque to Tintin, $17^{\circ} 58^{\prime} 5^{\prime \prime S} 65^{\circ} 21^{\prime} 36^{\prime W} \mathrm{~W}, 2104 \mathrm{~m}$, 22 March 2007, J. R. I. Wood E ${ }^{\circ}$ H. Huaylla 23197 (K, LPB). Prov. Quillacollo, Colcapirhua Hospital, $17^{\circ} 22^{\prime} \mathrm{S} 66^{\circ} 17^{\prime} \mathrm{W}, 2600 \mathrm{~m}, 11$ March 2004, J. R. I. Wood 20391 (BOLV, K, LPB). La Paz: Prov. Tamayo, Apolo, 14²4'S 68²5'10"W, 976 m, 5 Sept. 2004, L. Cayola et al. 960 (BOLV, LPB, MO). Santa Cruz: Prov. Cordillera, Charagua, 800 m, May 1934, M. Cardenas 2725 (LIL). Prov. Florida, c. $1 \mathrm{~km}$ from Samaipata village along road to Santa Cruz, $18^{\circ} 10^{\prime} 36^{\prime \prime S} 63^{\circ} 51^{\prime} \mathrm{W}, 1618 \mathrm{~m}, 13$ May 2012, J. R. I. Wood 27585 (K, LPB, USZ). Prov. Ibañez, University campus, Fac. Veterinaria, 400 m, 5 June 1994, A. Fuentes 382 (BOLV, LPB, USZ); by the railway c. $1 \mathrm{~km}$ W of Puerto Pailas, $250 \mathrm{~m}, 4$ March 2001, J. R. I. Wood 17181 (K, LPB, USZ). Prov. Santiesteban, on W side of Río Grande crossing on road from

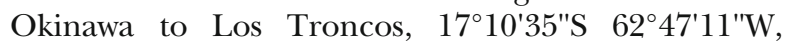
266 m, 26 July 2014, J. R. I. Wood E D. Soto 27951 (LPB, OXF, USZ). Prov. Warnes, $4 \mathrm{~km} \mathrm{WSW} \mathrm{of}$ Puerto Nuevo on the Río Grande along road to Okinawa, $17^{\circ} 12^{\prime} \mathrm{S} 62^{\circ} 48^{\prime} \mathrm{W}, 250 \mathrm{~m}, 11$ Jan. 1998, M. Nee 47897 (MO, NY, USZ). Tarija: Prov. Arce, Sidras-Campo La Lima, 22 $14^{\prime} 57^{\prime \prime S} 64^{\circ} 32^{\prime} 58^{\prime \prime W}, 890$ m, 11 April 2004, M. Serrano E J. Villalobos 5001 (MO). Prov. Cercado, outskirts of Tarija, 27 Feb. 1983, L. Bohs 2074 (GH, LPB).

CONSERVATION STATUS. Least concern (LC).

PHENOLOGY. Found in flower in all seasons from January to September.

NOTES. Readily identified by the $5-7$-foliolate leaves and the unique, stipule-like outgrowths at the base of the petiole. The corolla is very variable in size and in the Old World the leaflets are sometimes fused at the base, the leaves being deeply 5 - 7-lobed.

Species 79 - 84. The Pharbitis group. Characterised by the herbaceous sepals and minutely tomentellous seeds which are glabrous to the naked eye. The stigma is obscurely 3-lobed and the capsule is up to 6-seeded.

79. Ipomoea magnifolia Rusby (1896: 84). Type: Bolivia, Cochabamba, Espiritu Santo, M. Bang 1277 (lectotype NY, barcode 319197, designated here; isolectotypes: K, MO, NY, US barcode 0111417).

Vigorous liana to $7 \mathrm{~m}$, stems pubescent. Leaves petiolate, very large, $11-20 \times 7-20 \mathrm{~cm}$, ovate (rarely shallowly 3-lobed), acuminate to a fine point, cordate with rounded auricles, thinly to densely adpressed pubescent on both surfaces; petioles $5-15 \mathrm{~cm}$, pubescent. Inflorescence of long-pedunculate, axillary, rather compact cymes, peduncle $8-30 \mathrm{~cm}$, pubescent; bracteoles $10-11 \mathrm{~mm}$, linear or filiform, finely acuminate, caducous; secondary peduncles $1-1.5(-10) \mathrm{cm}$, pedicels 3 - $14 \mathrm{~mm}$, pubescent; sepals very unequal, somewhat variable in shape and size, outer sepals 12 $17 \times 4-5 \mathrm{~mm}$, broadly lanceolate, acuminate, the tips usually recurved, pilose to glabrous, inner sepals $7-10 \times$ 3-4 mm, oblong, obtuse or acute, sometimes mucronate, pilose to merely ciliate, margin scarious; corolla 7 $9 \mathrm{~cm}$ long, mauve, funnel-shaped with broad tube, in bud pubescent but glabrescent later, limb $5-6 \mathrm{~cm}$ diam. Capsule and seeds not seen. Fig. 31A.

TYPIFICATION. We have formally designated the specimen at NY (barcode 319197) with O'Donell's annotation as lectotype. This is necessary as at least some sheets of Bang 1277 are Ipomoea chondrosepala Hallier f., for example the sheets at the Smithsonian (US) with barcodes 43737 and 1335819, and this confusion may extend to duplicates in other herbaria. All four sheets at NY, however, appear to be true I. magnifolia.

DISTRIBUTION \& HABITAT. Restricted to moist Andean forest in Bolivia and Peru. In Bolivia it grows from 750 to $1900 \mathrm{~m}$ in the lower cloud forest region in the Chapare and Yungas of La Paz. Map 16.

SPECIMENS EXAMINED. BOLIVIA. sin data, M. Bang 2246 p.p. (MICH, NY). Cochabamba: Prov. Chapare, Espiritu Santo, 1892, M. Bang 1277 (K, MO, NY); Antahuacana, Espiritu Santo, $160 \mathrm{~km}$ de Cochabamba, $750 \mathrm{~m}$, June 1909, O. Buchtien 2304 (NY); Locotol, $1800 \mathrm{~m}$, April 1950, M. Cardenas 458 (LIL). La Paz: Prov. Caranavi, 5-10 km E of Caranavi on road to Alto Beni ascending Serranía de Bellavista, 1400 m, 4 May 2002, J. R. I. Wood E T. Daniel 18384. Prov. Murillo, Valle de Zongo, $16^{\circ} 04^{\prime} \mathrm{S} 68^{\circ} 02^{\prime} \mathrm{W}, 30$ April 1990, J. Solomon 18838 (FTG, LPB, MO). Prov. Nor Yungas, 0.5 km NW de San Antonio, Coroico, 30 April 1986, F. de la Puente 1323 (CIP, Lima); $8 \mathrm{~km}$ from Coroico towards Coripata, pasando Concepción, 1900 m, 11 April 1990 S. G. Beck 17558 (LPB); Coroico, Río Huaranilla, $3 \mathrm{~km}$ below Chairo, 1200 m, 4 June 1994, S. G. Beck 21408 (K, LPB); c. $2 \mathrm{~km}$ from Coroico along road to Coripata, $1600 \mathrm{~m}, 6$ May 2002, J. R. I. Wood E T. Daniel 18416 (K, LPB). Prov. Saavedra, Charazani, debajo de Carijama, 1600 m, 29 April 1993, P. Gutte Eं B. Herzog 635 (LPB); ANMI Apolobamba, antes de Murumpampa, 15 13'06"S 68 40'20"W, 1300 m, 20 April 2005, A. Fuentes et al. 7073 (ARIZ, MO). Prov. Sud Yungas, Puente Villa, 16 23'08"S, 67³8'07"W, 1450 m, 30 April 2012, S. G. Beck 32903 (K, LPB). Prov. Tamayo, PN Madidi, Tunukili, SW of Mojos, 14³4'34'S 6852'54"W, 1820 m, 3 July 2005, A. Fuentes et al. 9300 (LPB, MO).

CONSERVATION STATUS. Using Geocat this species should be classified as Near Threatened (NT) in Bolivia based on an extent of occurrence of about $21,725 \mathrm{~km}^{2}$. This seems to accurately reflect the potential threat caused by the destruction of forest on the eastern Andean slopes. However it is likely to survive in secondary forest, on the sides of ravines and in forest relics which persist in inaccessible areas. 

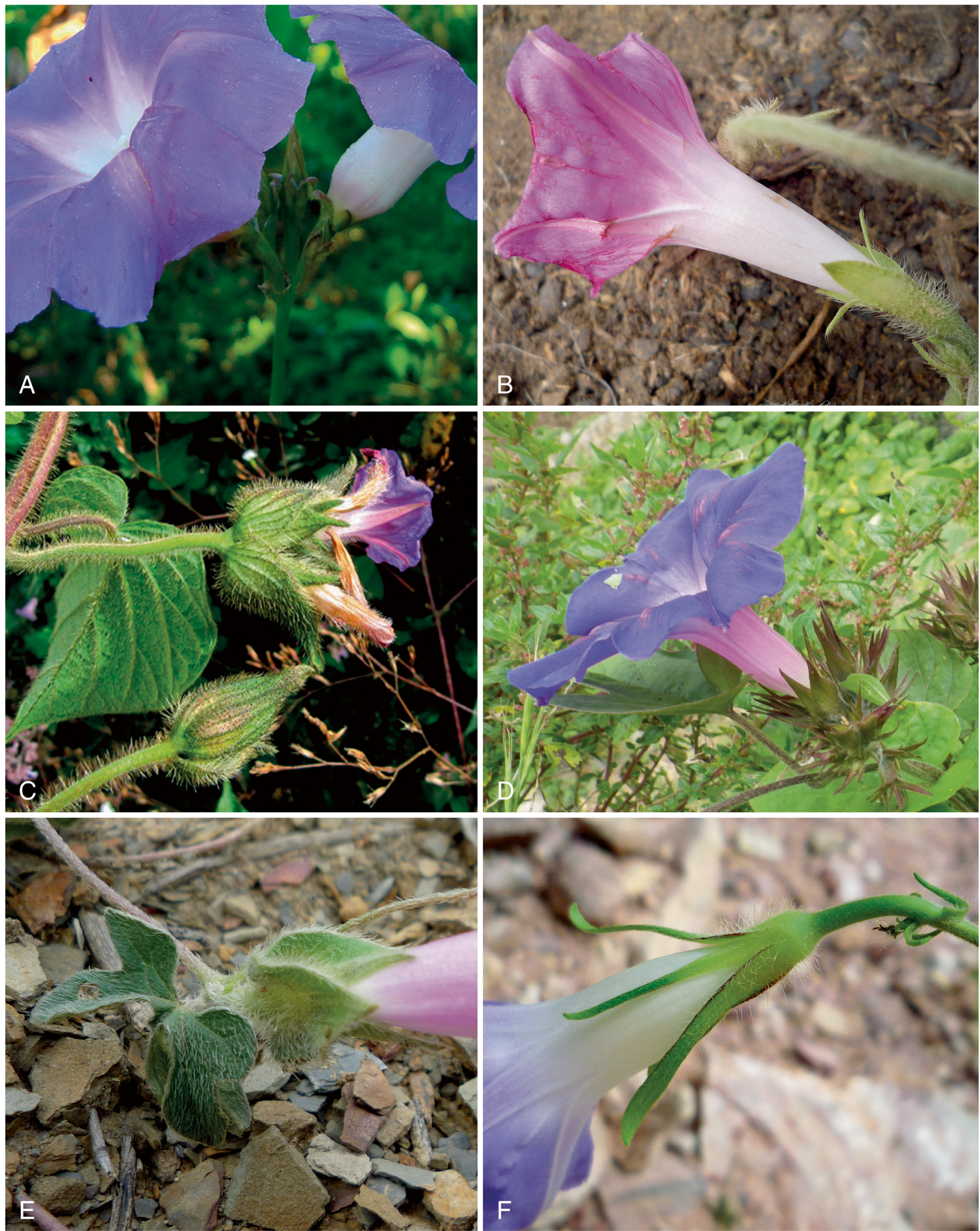

Fig. 31. A Ipomoea magnifolia; B I. purpurea (pink-flowered form); C I. neurocephala; D I. indica; E I. pubescens; F I. nil. PHOTos: A ALFREDO FUENTES; B, E - F BeTH WILLIAMS; C ALEXANDER PARADA; D JOHN WOOD. 


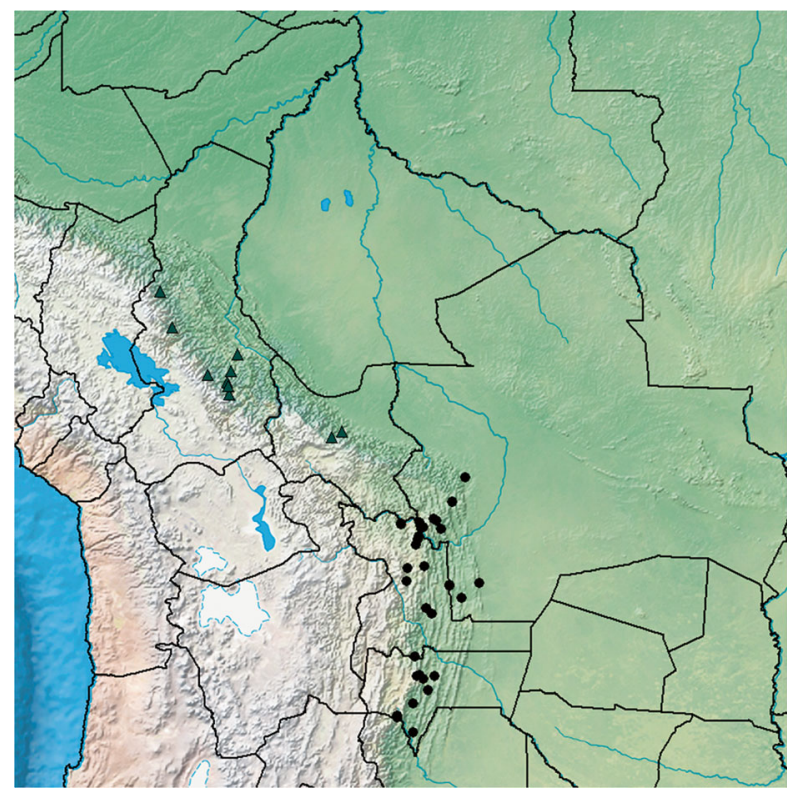

Map 16. Contrasting Andean distributions of Ipomoea magnfolia ( $\mathbf{\Lambda}$ ) of the Yungas and I. oranensis ( $)$ of the southern Tucuman-Bolivian forest region.

PHENOLOGY. It flowers at the end of the summer rainy season from April to early July.

NOTES. Somewhat resembling a large-leaved Ipomoea indica but leaves never grey-tomentose beneath, bracteoles caducous, sepals very unequal, the inner oblong, much shorter than the outer and the inflorescence not usually compact.

Ipomoea magnifolia is very variable with respect to the indumentum of the sepals and the corolla, varying from subglabrous to pilose, although there is always the tendency for hairs to fall with age. Fuentes et al. 9300 (MO) is a very unusual specimen, the inflorescence is exceptionally long-pedunculate and very dense, the outer sepals are broadly oblong not lanceolate, obtuse and mucronate, not acuminate and a mere $10 \mathrm{~mm}$ long.

80. Ipomoea indica (Burm.) Merrill (1917: 445).

Convolvulus indicus Burm. (Burman 1755: 6). Type: Besler, Hort. Eyst. Aest. Ord. 8: t. 2 (1613), lectotype designated by Fosberg (1976).

Ipomoea congesta R. Br. (Brown 1810: 485). Type: Australia, Queensland, Cape York Penisular, Banks Ev Solander (holotype BM).

Ipomoea acuminata (Vahl) Roem. \& Schult. (Roemer \& Schultes 1819: 228), non Ipomoea acuminata Ruiz \& Pavon (1799).

Convolvulus acuminatus Vahl (1794: 26). Type: not found at $\mathrm{C}$.

Twining perennial herb, stems pubescent. Leaves petiolate, $11 \times 11 \mathrm{~cm}$, ovate or, commonly, shallowly 3lobed, both forms sometimes on the same plant, apex acuminate and shortly mucronate, base cordate with rounded auricles, adaxially pubescent, abaxially paler, pubescent to grey-tomentose; petioles $2.5-7 \mathrm{~cm}$. Inflorescence of axillary, pedunculate clusters; peduncles $5-9 \mathrm{~cm}$, pubescent; bracteoles \pm persistent, pubescent, usually narrowly linear-lanceolate, acuminate, $4-10 \times$ $0.5-1 \mathrm{~mm}$ but sometimes oblong-elliptic, foliose and shortly petiolate, c. $15-30 \times 4-15 \mathrm{~mm}$; secondary peduncles $2-3 \mathrm{~mm}$; pedicels very short, $2-7 \mathrm{~mm}$; sepals subequal, $13-20 \times 3-5 \mathrm{~mm}$, narrowly ovate, finely acuminate, pubescent, often somewhat spreading at maturity; corolla $5-6 \mathrm{~cm}$, funnel-shaped, deep blue with violet midpetaline bands, drying pink, glabrous, limb unlobed, $4-5 \mathrm{~cm}$ diam. Capsule subglobose, 8 $10 \mathrm{~mm}$ diam., glabrous, 6-seeded; seeds black, $4-5 \mathrm{~mm}$ long, appearing glabrous but minutely tomentellous. Fig. 31D.

DISTRIBUTION \& HABITAT. Widely cultivated and frequently naturalised throughout tropical and semitropical countries of the world. Of New World, perhaps Mexican, origin, it is not native in India despite its name. Although found in all neighbouring countries it is unexpectedly rare in Bolivia and has not been recollected for almost fifty years.

SPECIMENS EXAMINED. BOLIVIA. Cochabamba: Prov. Cercado: Valle de Cochabamba, $2570 \mathrm{~m}, 14$ April 1966, R. Steinbach 69 (F, LPB, MICH, MO, NY, US).

CONSERVATION STATUS. Not assessed. It is an introduced species of uncertain status.

PHENOLOGY. Collected in flower in April but likely to flower in most months of the year.

NOTES. This species might be confused with Ipomoea purpurea and I. magnifolia but it is usually easily distinguished by the leaves grey-pubescent or tomentose beneath and the clustered flowers with very persistent bracteoles.

\section{Ipomoea purpurea (L.) Roth (1787: 27).}

Convolvulus purpureus L. (Linnaeus 1762: 219). Type: Dillenius, Hort. Eltham. 1: 100, t. 84, f. 97 (1732), designated by D. F. Austin (1975: 193).

Twining annual herb, stems pilose. Leaves petiolate, 3 $8(-15) \times 3.5-8(-14) \mathrm{cm}$, ovate (rarely 3-lobed to half way), shortly acuminate, cordate with rounded auricles, both surfaces thinly to densely hispid-pilose; petioles $3-15 \mathrm{~cm}$, pilose. Inflorescence of $2-5$ flowered, pedunculate, axillary cymes, often umbellate in form; peduncles $1.5-7 \mathrm{~cm}$, pubescent; bracteoles $2-8 \mathrm{~mm}$, filiform, relatively persistent, pedicels $0.5-$ $1.8 \mathrm{~cm}$, pubescent but pilose apically; sepals subequal, $11-17 \times 2-3 \mathrm{~mm}$, lanceolate to oblong-lanceolate, acuminate to subobtuse, hispid-pilose, more densely so in lower half, inner sepals with scarious margins; corolla $4-5 \mathrm{~cm}$, funnel-shaped, tube white, limb usually 
pink, sometimes cream or bluish, glabrous, $4 \mathrm{~cm}$ diam., unlobed. Capsule subglobose, 9 - $11 \mathrm{~mm}$, glabrous, 6-seeded; seeds $5 \mathrm{~mm}$ long, appearing glabrous but minutely tomentellous under a microscope. Fig. 31B.

DISTRIBUTION \& HABITAT. Widely distributed throughout the tropics as an escape from cultivation or as a weed. There are more than 60 records from Bolivia but it is only commonly naturalised in the InterAndean dry valleys where it is frequent around villages between around $1000 \mathrm{~m}$ and $2800 \mathrm{~m}$. There are a few records from the La Paz area at higher altitudes and a scattering from villages in the drier lowlands but it is not common in these areas. Map 17.

SELECTED SPECIMENS OF 64 EXAMINED. BOLIVIA. Chuquisaca: Prov. Azurduy, trayecto Sopachuy Tarabuquillo, 19²7'13"S 64²8'55"W, 2122 m, 27 April 2008, J. A. Peñaranda et al. 631A (HSB). Prov. Boeto, Com. Huerta Mayu, $3 \mathrm{~km} \mathrm{~S}$ of Villa Serrano, 1909'02"S 64¹8'09"W, 2150 m, 10 Feb. 1994, M. Serrano 1253 (HSB). Prov. Oropeza, by road from Sucre to Yotala, c. $1 \mathrm{~km}$ below La Glorieta, $19^{\circ} 08^{\prime} \mathrm{S} 65^{\circ} 16^{\prime} \mathrm{W}, 2750 \mathrm{~m}, 2$ March 2003, J. R. I. Wood 19287 (HSB, K, LPB). Prov. Tomina, 3 - 4 km antes de Padilla, camino entre el Puente Azero y Padilla, 19 $21^{\circ} \mathrm{S} 64^{\circ} 18^{\prime} \mathrm{W}, 26$ March 2013, J. R. I. Wood et al. 27656 (K, LPB, USZ). Cochabamba: Prov. Arque, 2800 m, 28 Jan. 1992, P. Ibisch 1015 (LPB). Prov. Capinota, Playa Ancha, 1743'S 66 ${ }^{\circ} 16^{\prime} \mathrm{W}, 2380$ m, 7 April 2000, Gutiérrez 15 (LPB). Prov. Carrasco, $1 \mathrm{~km}$ al $\mathrm{N}$ de Hoyadas, sobre el camino hacia Totora, $18^{\circ} 55^{\prime} 11^{\prime \prime S} 65^{\circ} 09^{\prime} 51^{\prime \prime W}, 2409$ m, 23 March 2003, J. R. I. Wood et al. 19429 (BOLV, HSB, K, LPB, USZ). Prov. Cercado, canal en la zona de El Linde, cerca a Tudela, $2620 \mathrm{~m}, 10$ April 1997, M. Atahuachi 716 (BOLV). Prov. Chapare, on climb out of Cochabamba valley towards the Chapare, 2800 m, 29 Jan. 1995, J. R. I. Wood 9246 (K, LPB). Prov. Mizque, Tako Tako, $18^{\circ} 00^{\prime} \mathrm{S}$ $65^{\circ} 15^{\prime} \mathrm{W}, 1900 \mathrm{~m}, 21$ Dec. 1949, W. M. A. Brooke 5890 (BM). Prov. Quillacollo, Quillacollo, 17²2'S 66 $6^{\circ} 19^{\prime} \mathrm{W}, 2675$ m, 3 March 1988, M. Saldias 253 (NY, USZ). La Paz: Prov. Inquisivi, Licoma Pampa, $16^{\circ} 48^{\prime} \mathrm{S} 67^{\circ} 13^{\prime} \mathrm{W}, 1750 \mathrm{~m}, 22$ - 23 June 1988, M. Lewis 88908 (K, LPB, MO). Prov. Iturralde, Bala, 350 m, 28 Nov. 1921, M. Cardenas in Rusby 1867 (NY). Prov. Loayza, Luribay, $17^{\circ} 03^{\prime} \mathrm{S}$ 67³9'55"W, 2493 m, 1 March 2003, T. Ortuño 253 (K, LPB). Prov. Murillo, Calacoto, $16^{\circ} 31^{\prime} \mathrm{S} 68^{\circ} 05^{\prime} \mathrm{W}$, 3300 m, 20 May 1988, J. Solomon 18361 (LPB, MO, USZ). Prov. Nor Yungas, Coripata, 28 March 1894, M. Bang 2113 (BM, F, GH, K, LPB, MO, NY, US). Prov. Sud Yungas, Chulumani, salida hacia Ocobaya, 1800 m, 28 June 1985, S. G. Beck 12083 (LPB, NY, USZ). Potosi: Prov. Nor Chichas,

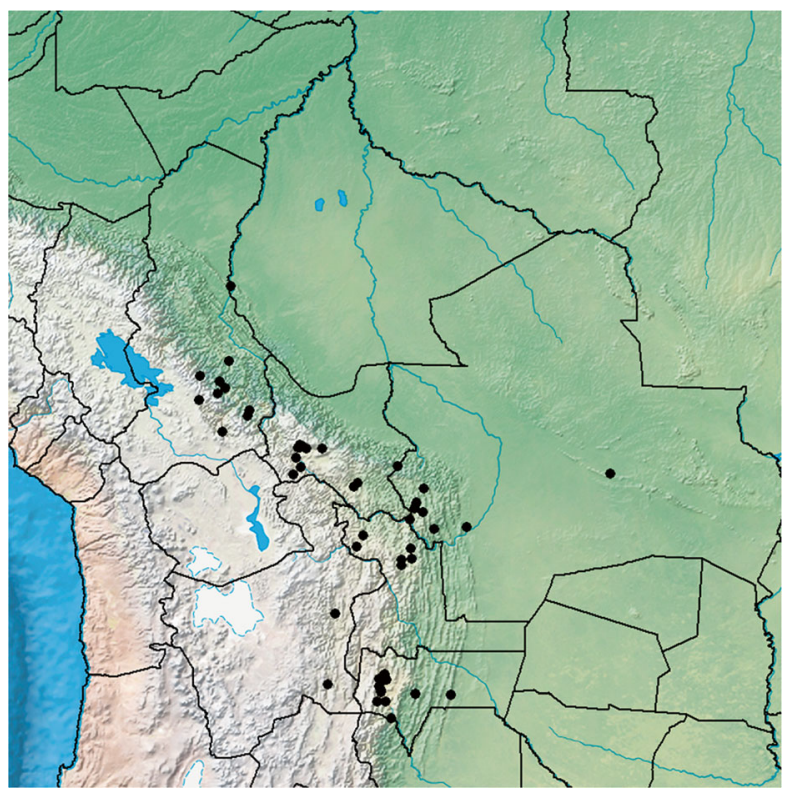

Map 17. Distribution of Ipomoea purpurea (O), a weedy species most common in the inter-Andean dry valleys.

Cotagaita, 20²' $19^{\prime} \mathrm{6} 5^{\circ} 39^{\prime} \mathrm{W}, 2684 \mathrm{~m}, 30$ April 2005, Zamora 321 (LPB). Prov. Sud Chichas, Espicaya, 213' S 6547'24"W, $2960 \mathrm{~m}, 28$ Feb. 2012, F. Zenteno et al. 11569 (K, LPB). Santa Cruz: Prov. Caballero, Río Arriba, $3 \mathrm{~km}$ above Comarapa, $17^{\circ} 42^{\prime} \mathrm{S}$ 643' $\mathrm{W}, 1900 \mathrm{~m}, 30$ March 1996, J. Balcazar $\mathcal{E}$ Franco 471 (LPB, USZ). Prov. Chiquitos, San José de Chiquitos, $300 \mathrm{~m}$, Feb. 1950, M. Cardenas 4478 (LIL). Prov. Cordillera, Cabezas, $420 \mathrm{~m}, 3$ March 1945, I. Peredo 345 (NY). Prov. Florida, $5.6 \mathrm{~km}$ from Pampa Grande along pipeline, $1400 \mathrm{~m}, 13$ Aug. 1991, P. Acevedo et al. 4549 (ARIZ, NY, US, USZ). Prov. Vallegrande, camino de Naranjos a Pampa Negra, 18 ${ }^{\circ} 25^{\prime}$ - 28'S 6414' - 16'W, 1689 1970 m, 31 May 2010, G. A. Parada E V. Rojas 2664 (MO, OXF, USZ). Tarija: Prov. Arce, PadcayaChaguaya, $21^{\circ} 53^{\prime} \mathrm{S} 64^{\circ} 46^{\prime} \mathrm{W}, 2000 \mathrm{~m}, 16$ March 1998, S. G. Beck et al. 26134 (ARIZ, LPB, MO). Prov. Avilez, Concepción, 21 ${ }^{\circ} 46^{\prime} \mathrm{S} 63^{\circ} 36^{\prime} \mathrm{W}$, 1700 m, 15 March 1994, M. Subieta 165 (LPB). Prov. Cercado, entre Tarija y Tomatitas, $1920 \mathrm{~m}, 2$ Feb. 1986, E. Bastian 683 (LPB). Prov. Mendez, fin del valle, Coimata, 2080 m, 18 Dec. 1985, E. Bastian 146 (ARIZ, LPB). Prov. O’Connor, Com. Salinas, $21^{\circ} 45^{\prime} 20^{\prime \prime S} 64^{\circ} 13^{\prime} 28^{\prime \prime W}, 1118$ m, 29 March 2006, M. Serrano $\mathcal{E} J$ J. Villalobos 7577 (LPB).

CONSERVATION STATUS. Least Concern (LC).

PHENOLOGY. Like many annuals, this species flowers predominantly in late summer at the end of the rainy season from February to June. Occasional records are known from other months but these are atypical.

NOTES. Ipomoea purpurea is sometimes confused with I. nil but can usually be distinguished by the shorter 
oblong-lanceolate sepals, pink flowers and unlobed leaves. However flower colour is variable and very rarely lobed-leaved specimens are encountered. Specimens with lobed leaves can be named:

Ipomoea purpurea var. diversifolia (Lindl.) O'Donell (1953: 385).

Pharbitis diversifolia Lindl. (Lindley 1837: t. 1988). Type: Peru, Mathews 2050, portion at top right of sheet in Herb Lindley (CGE 06401 p.p.), lectotype, designated here, isolectotype OXF.

SPECIMENS eXAMINED. BOlIVIA. Tarija: Prov. Cercado, Pampa Redonda, 21 41'22"S 6450'20"W, 7 Feb. 2006, F. Zenteno et al. 3492 (LPB).

TYPIFICATION. The protogue of Pharbitis diversifolia suggests that the 3-lobed leaves are found on plants which also have entire leaves. This may sometimes be the case but the type material consists of two specimens, one labelled Mathews 2050 from Peru, with 3-lobed leaves clearly corresponding to the illustration in the Botanical Register while a second specimen with entire leaves presumably represents the material collected by Dickson in Mexico. The lectotypification above excludes this Mexican material with entire leaves.

82. Ipomoea nil (L.) Roth (1797: 36).

Convolvulus nil L. (Linnaeus 1762: 219). Type: "Convolvulus caeruleus, hederaceo folio..", Dillenius, Hort. Eltham. 1: 96, t. 80, f. 91 (1732), designated by Verdcourt (1957: 232 - 233).

Trailing or twining herb, stems roughly pilose. Leaves petiolate, $3-12 \times 3-14 \mathrm{~cm}$, 3-lobed, the lobes typically ovate, abruptly narrowed to an acute or very shortly acuminate apex, base cordate, thinly to densely pubescent on both surfaces, paler beneath; petioles $1.5-7 \mathrm{~cm}$. Inflorescence of pedunculate axillary compact cymes, sometimes reduced to $1-2$ flowers; peduncles $0.5-18 \mathrm{~cm}$, usually pilose; bracteoles $3-7 \mathrm{~mm}$, filiform, relatively persistent; secondary peduncles $3-8 \mathrm{~mm}$; pedicels $3-10 \mathrm{~mm}$; sepals $15-32 \mathrm{~mm}$, lanceolate, tapering into a long linear point, densely pilose with bulbous-based hairs, especially near the base; corolla $3.5-4.5 \mathrm{~cm}$, funnel-shaped, glabrous, tube white, limb blue, drying pink, 3 - 4 cm diam., unlobed. Capsule $7-10 \times 6 \mathrm{~mm}$, subglobose, glabrous, style slender, persistent; seeds puberulent. Fig. 31F.

DISTRIBUTION \& HABITAT. A pantropical weed of disturbed places. In Bolivia this is a very common species of disturbed bushy places, often near settlements. It is far more common in the lowlands than Ipomoea purpurea, being found particularly in the Andean foothills, the Chaco fringes and the Chiquitania. It becomes rare above $1000 \mathrm{~m}$, but is also common in the Yungas of La
Paz where it reaches at least $2100 \mathrm{~m}$. Like I. hederifolia and I. purpurea it is virtually absent from the Beni and Pando. The lack of records from Cochabamba and much of Chuquisaca is also noteworthy. Map 18.

SELECTED SPECIMENS OF 64 EXAMINED. BOLIVIA. Beni: Prov. Ballivian, Huahuamo-Reyes, 300 m, June 1955, M. Cardenas 5389 (LIL). Prov. Cercado, Trinidad airport, 9 April 1979, A. Krapovickas E A. Schinini (MICH). Chuquisaca: Prov. Luis Calvo, SalvadorCIMBOC, $20^{\circ} 40^{\prime S} 63^{\circ} 10^{\prime} \mathrm{W}, 15$ April 1993, E. Saravia et al. 11832 (LPB, MO). Prov. Oropeza, on descent to Río Chico, 2100 m, 26 March 1995, J. R. I. Wood 9604 (K, LPB). Prov, Zudañez, subida del Río Grande a Mojocollo, en camino de Pasorapa a Mojocollo, 1843'41"S 64³3'29"W, 1769 m, 31 March 2013, J. R. I. Wood et al. 27725 (K, LPB, USZ). La Paz: Prov. Larecaja, Hac. Casana, Tipuani, 1400 m, 17 Jan. 1923, O. Buchtien 7449 (BM, LIL). Prov. Murillo, vic. La Paz, 1890, M. Bang 534 (BM, F, GH, K, MICH, MO, NY, US). Prov. Nor Yungas, Milluguaya, 1300 m, Dec. 1917, O. Buchtien 605 (GH, K, LIL, MO, NY, US). Prov. Saavedra, ANMI Apolobamba, Quita Caleon-Comata, 15¹4'S 6845'09"W, 1448 m, 11 Sept. 2004, L. Cayola et al. 1370 (ARIZ, LPB). Prov. Sud Yungas, El Paraiso, $6 \mathrm{~km}$ arriba de Chulumani, 16 $38^{\circ} \mathrm{S} 67^{\circ} 37^{\prime} 38^{\prime \prime} \mathrm{W}, 2018$ m, 7 April 2012, S. G. Beck et al. 32840 (K, LPB). Prov. Tamayo, Tuichi: Yarimita, 14³2'48"S 6841'37"W, 940 m, 8 March 2005, A. Araujo-M. et al. 1781 (ARIZ, BOLV, LPB, MO). Santa Gruz: Prov. Germán Busch, between Candelaria and Santa Ana de Chiquitos on the road from Taperas to Carmen Rivero Tórrez, $18^{\circ} 40^{\prime} 54^{\prime \prime S} 58^{\circ} 52^{\prime} 07^{\prime \prime} \mathrm{W}, 176 \mathrm{~m}, 18$ April 2013, J. R. I. Wood et al. 27833 (K, LPB, OXF, USZ). Prov. Caballero, 5 - $6 \mathrm{~km}$ de Comarapa a San Isidro en el antiguo camino Cochabamba-Santa Cruz, 1757'08"S

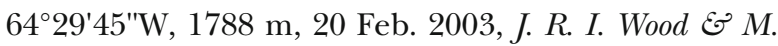
Mendoza 19127 (K, LPB, USZ). Prov. Chiquitos, on trail from Chochís village to Matacuzal, c. 30 minutes from village, $18^{\circ} 07^{\prime} \mathrm{S} 60^{\circ} 01^{\prime} \mathrm{W}, 450 \mathrm{~m}, 19 \mathrm{March} 2005, J$. R. I. Wood E A. Haigh 21935 (K, LPB). Prov. Cordillera, PN Kaa-Iya del Gran Chaco, 1954'45"S 62 $19 ' 57^{\prime}$ 'W, 320 m, 19 July 1998, A. Fuentes E G. Navarro 2630 (USZ). Prov. Florida, Río Paredones, $0.5 \mathrm{~km} \mathrm{~N}$ of Achiras Camping, $18^{\circ} 09^{\prime} \mathrm{S} 63^{\circ} 49^{\prime} \mathrm{W}, 1350 \mathrm{~m}, 8$ March 1998, M. Nee 48589 (LPB, MO, NY, USZ). Prov. Ibañez, Santa Cruz, Barrio Macdonald, $17^{\circ} 46^{\prime} \mathrm{S} 63^{\circ} 11^{\prime} \mathrm{W}, 3$ March 1998, M. Nee 48552 (MO, NY, USZ). Prov. Ichilo, Buenavista, 500 m, 19 Feb. 1921, J. Steinbach 5348 (F, GH, MO, NY, US). Prov. Ñuflo de Chávez, Cuatro Cañadas, $17^{\circ} 16^{\prime} \mathrm{S}, 62^{\circ} 15^{\prime} \mathrm{W}, 262 \mathrm{~m}, 28$ March 1996, J. Balcazar E Franco 464a (LPB, USZ). Prov. Santiesteban, $15.5 \mathrm{~km} \mathrm{~N}$ of Mineros, $16^{\circ} 59^{\prime} \mathrm{S}$ $63^{\circ} 11^{\prime} \mathrm{W}, 225$ m, 28 Aug. 1996, M. Nee 47090 (MO, NY, USZ). Prov. Vallegrande, Trigal, Río la Ciénaga, 18¹8'22"S 640'ㄷㄴ'W, 1651 m, 3 March 2011, L. Arroyo et al. 5165 (USZ). Prov. Velasco, $30 \mathrm{~km}$ from Santa Rosa de la Roca on the road to Piso Firme, $15^{\circ} 37^{\prime} 34^{\prime \prime S}$ 


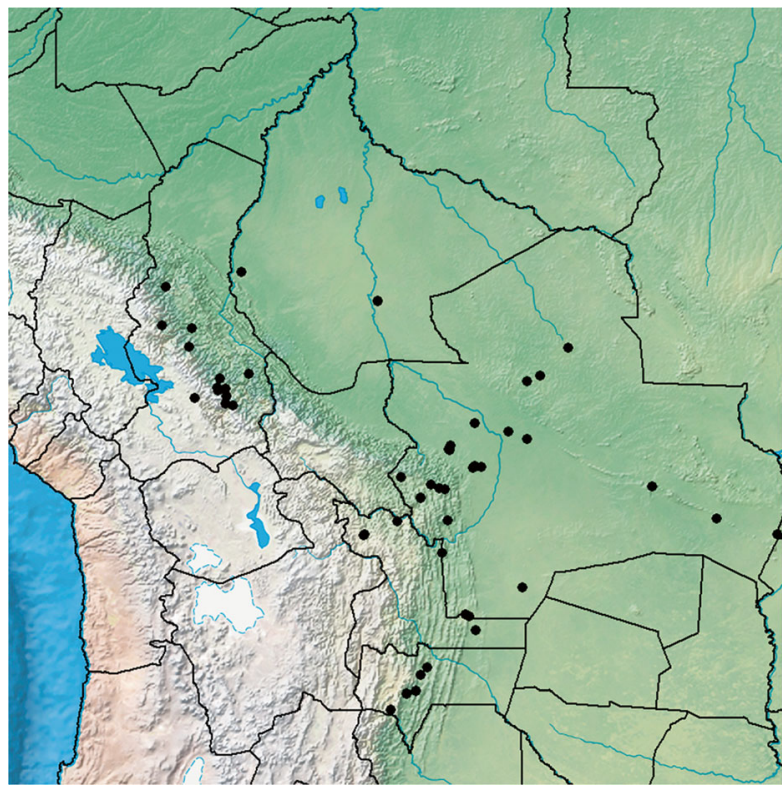

Map 18. Distribution of Ipomoea nil (๑), a weedy species most common in the drier lowlands, absent from the Amazonian region.

61 31'12"W, 361 m, 13 April 2013, J. R. I. Wood et al. 27801 (K, LPB, USZ). Prov. Warnes, Las Barreras, 375 m, 10 June 1980, F. E. Tollervey 2517 (K). Tarija: Prov. Arce, Río Negro, 24 Feb. 1960, T. Meyer et al. 20837 (LIL). Prov. Mendez, cerca Colon Morte, 28 Feb. 1986, E. Bastian 864 (LPB). Prov. O'Connor, $8.3 \mathrm{~km}$ E of Entre Rios, camino a Villamontes, $21^{\circ} 27^{\prime} 55^{\prime \prime} \mathrm{S} 64^{\circ} 8^{\prime} 57^{\prime \prime} \mathrm{W}, 1098$ m, 3 April 2009, M. Dematteis et al. 3434 (CTES, K).

CONSERVATION STATUS. Least Concern (LC).

PHENOLOGY. Found in flower virtually throughout the year but, like other annual species, predominantly in autumn at the end of the rainy season from February to July.

NOTES. The blue flowers, 3-lobed leaves and long, pilose sepals which taper from near the base make this an easily identified species in Bolivia. However, it has commonly been misnamed Ipomoea hederacea Jacq., a species principally of the United States, which is distinguished by its smaller corolla and the recurved fleshy tips of the sepals.

83. Ipomoea pubescens Lam. (Lamarck 1793: 465). Type: America (holotype P-LAM, P00357477!).

Low trailing or twining herb with slender stems, pubescent in all parts, rootstock a carrot-shaped tuber. Leaves petiolate, $2-6(-8) \times 2-6 \mathrm{~cm}$, ovate or, usually in Bolivia, 3 - 5-lobed to near base, lobes oblongelliptic, narrowed at both ends, acute, shortly mucronate, laterals sometimes shallowly lobed near base, base cordate with rounded auricles, both surfaces densely pubescent; petioles $1-2 \mathrm{~cm}$, pubescent. Inflorescence of solitary or, occasionally paired, axillary flowers; peduncles $1-4 \mathrm{~cm}$, pubescent; bracteoles 4 $8 \mathrm{~mm}$ long, linear, persistent, pubescent; pedicels $2-6$ $\mathrm{mm}$, pubescent; sepals unequal, grey-pubescent or pilose, outer $12-22 \times 6-10 \mathrm{~mm}$, ovate, acuminate, base cordate, inner lanceolate, $2-4 \mathrm{~mm}$ wide; corolla 4 - $5 \mathrm{~cm}$, funnel-shaped, glabrous, tube flushed reddish, limb purplish, c. $2 \mathrm{~cm}$ diam., unlobed but midpetaline bands terminating in a tooth. Capsule subglose, $8 \mathrm{~mm}$ long, glabrous, enclosed by sepals, 3locular, 6-seeded; seeds $4 \mathrm{~mm}$ long, minutely tomentellous. Fig. 31E.

DISTRIBUTION \& HABITAT. Ipomoea pubescens is amphitropical in its distribution occurring in the United States and Mexico and along the Andes from Peru south to northern Argentina with an isolated station in central Colombia. In Bolivia it is locally common in dry stony grassland in the inter-Andean valleys from the Tarija area north to the La Paz region where it reaches almost $3900 \mathrm{~m}$ in altitude. It is not recorded below 2300 and is unexpectedly rare in the valles cruceños and north of La Paz. Map 19.

SELECTED SPECIMENS OF 40 EXAMINED. BOLIVIA. Chuquisaca: Prov. Oropeza, between Yotala and Sucre, $19^{\circ} 07^{\prime} 35^{\prime \prime S} 65^{\circ} 15^{\prime} 42^{\prime \prime} \mathrm{W}, 2513 \mathrm{~m}, 21$ Feb. 2004, J. R. I. Wood E J. Gutiérrez 20195 (HSB, K, LPB). Prov. Tomina: $14 \mathrm{~km}$ de Padilla hacia Monteagudo, $2170 \mathrm{~m}$, 8 March 1981, S. G. Beck 6269 (FTG, LPB). Prov. Yamparaez, along road from Tarabuco to Zudañez c. $2 \mathrm{~km}$ above gorge of Lamboyo, $19^{\circ} 06^{\prime} \mathrm{S} 64^{\circ} 52^{\prime} \mathrm{W}, 2600$ m, 17 March 2002, J. R. I. Wood 17844 (HSB, K, LPB). Cochabamba: Prov. Campero, c. $22 \mathrm{~km}$ de Pasorapa, sobre el camino a Buena Vista, 18 24'13"S 64³5'15"W, 2511 m, 24 March 2003, J. R. I. Wood et al. 19449 (BOLV, HSB, K, LPB, USZ). Prov. Capinota, Apillapampa, $17^{\circ} 52^{\prime} 47^{\prime \prime S} 66^{\circ} 14^{\prime} 91^{\prime \prime} \mathrm{W}, 3100 \mathrm{~m}, 20$ March 2003, E. Thomas 307 (BOLV, LPB). Prov. Cercado San Pedro, 2590 m, 10 Jan. 1996, N. de la Barra 162 (BOLV). Prov. Punata, Cerro Tuti, NW of San Benito, 2700 m, March 1998, A. Fuentes E Fuentes 2657 (USZ). Prov. Tiraque, on plain just before ascent leaving valley on road from Cochabamba to Epizana, $17^{\circ} 27^{\prime} \mathrm{S} 65^{\circ} 43^{\prime} \mathrm{W}, 2600 \mathrm{~m}, 25$ Jan. 2000, J. R. I. Wood 15892 (BOLV, HSB, K, LPB). Prov. Quillacollo, above Taquiña brewery, 2880 m, 23 March 1994, N. Ritter 671 (NY). La Paz: Prov. Larecaja, Sorata, San Pedro, 2550 2700 m, Feb. - March 1861, G. Mandon 1487 (BM, K). Prov. Murillo, $2 \mathrm{~km}$ below Mecapaca, $16^{\circ} 40^{\prime} \mathrm{S} 68^{\circ} 01^{\prime} \mathrm{W}$, 2900 m, 28 March 1982, J. Solomon 7406 (FTG, LPB, MO, NY). Potosi: Prov. Charcas, Torotoro, desvio del camino principal rumbo al Vergel, $18^{\circ} 07^{\prime} 11^{\prime \prime S}$ 6546'10"W, 2649 m, 26 Feb. 2003, J. R. I. Wood et al. 19215 (BOLV, K, LPB). Santa Cruz: Prov. Vallegrande, subida de Guadalupe a Piraimiri. 5 - $10 \mathrm{~km}$ de Guadalupe, 18³4'16"S 6403'24"W, 2216 m, 28 March 2013, J. R. I. Wood et al. 27675 (K, LPB, OXF, USZ). Tarija: Prov. Arce, Padcaya, Com. Orozas Arriba, $21^{\circ} 54^{\prime} 13^{\prime \prime S ~ 6436 ' 56 " W, ~} 2661$ m, 3 Jan. 2005, M. Serrano 


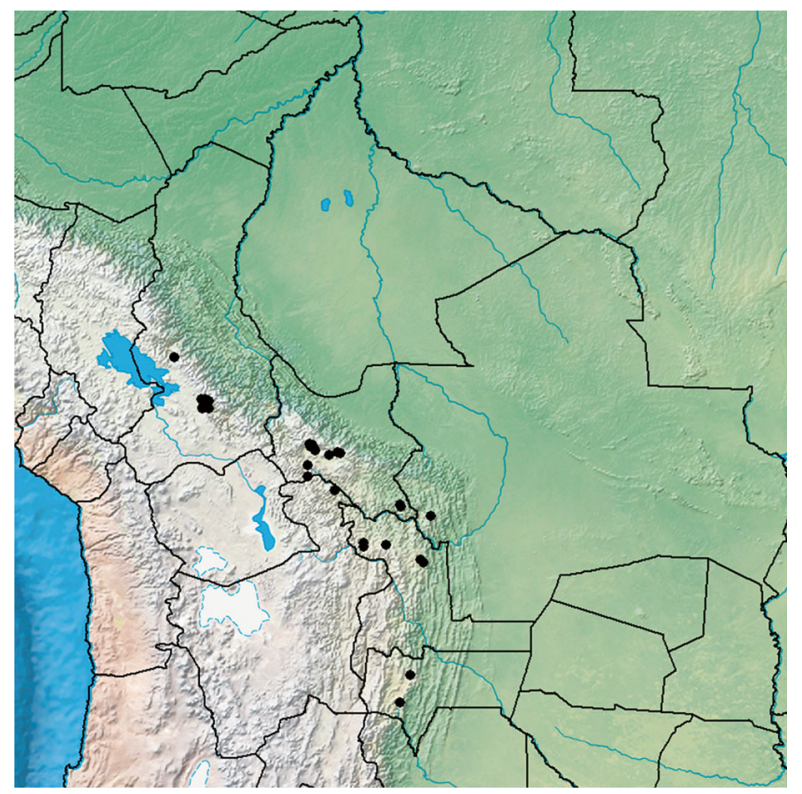

Map 19. Distribution of Ipomoea pubescens ( ), a characteristic species of the inter-Andean dry valleys, noticeably less common in the north of Bolivia.

et al. 5938 (ARIZ, MO). Prov. Cercado, Cuesta El Condor, Tarija-Entre Rios, 21 25'10"S, 64²5'37"W, 2641 m, 15 Feb. 2008, M. Mendoza et al. 2850 (USZ).

CONSERVATION STATUS. Least concern (LC).

PHENOLOGY. Flowers in response to rain so found in flower during the summer rains mostly from December to March.

NOTES. A very distinct species on account of its deeplylobed, hirsute leaves and its ovate, basally cordate, outer sepals.

84. Ipomoea neurocephala Hallier f. (Hallier 1899a: 40). Type: Bolivia, Sorata, G. Mandon 1489 (holotype B†; isotype $\mathrm{K}$ !)

Ipomoea sawyeri D. F. Austin (1991: 93), synon. nov. Type: Peru, Puno, F. de la Puente 3271 (holotype not received at US; isotypes FAU, now Fairchild FTG!, CIP in Lima!).

Twining, probably annual herb, stems hispid-pilose. Leaves petiolate, $2.5-7.5 \times 2-8 \mathrm{~cm}$, ovate, shallowly cordate and broadly cuneate onto the petiole, auricles rounded, apex shortly acuminate, both surfaces appressed pilose, abaxially paler; petioles $2-8 \mathrm{~cm}$, hispid-pilose. Inflorescence of dense pedunculate axillary heads with $1-5$ flowers; peduncles $2-12 \mathrm{~cm}$, hispid-pilose; bracteoles $7-20 \times 7-24 \mathrm{~mm}$ (but smaller inside head), ovate, acuminate, pale green with prominent dark green veins, persistent, forming an involucre around the flowers; pedicels $1-3 \mathrm{~mm}$; sepals long-pilose, dissimilar, outer $12-14 \times 4-5 \mathrm{~mm}$, ovate, acuminate to an obtuse apex, inner linear-lanceolate, $9 \times 2 \mathrm{~mm}$; corolla $2-3.5(-5) \mathrm{cm}$, pilose with very long hairs, narrowly funnel-shaped, tube pale with dark midpetaline bands, limb mauve, weakly lobed, c. $1.5 \mathrm{~cm}$ in diam. Capsule ovoid, glabrous, seeds minutely puberulent. Fig. 31C.

DISTRIBUTION \& HABITAT. This species is of very scattered occurrence in Andean Bolivia and Peru and is probably conspecific with Ipomoea federalis Afzel. from Brazil and I. igualensis House from Mexico. In Bolivia it grows between 1800 and $2400 \mathrm{~m}$ in areas of dry forest.

SPECIMEnS eXAMINed. BOLIVIA. La Paz: Prov. Larecaja, Sargchani, 2400 m, June 1860, G. Mandon 1489 (F, G, K). Prov. Munecas, Carpa, al lado del Río Charazani, $15^{\circ} 12^{\prime} 47^{\prime S} 68^{\circ} 49^{\prime} 34^{\prime W}, 1900$ m, 5 May 2000, A. Fuentes E R. Cuevas 7966 (ARIZ, MO, USZ). Prov. Sud Yungas, El Paraiso, $6 \mathrm{~km}$ arriba de Chulumani, $16^{\circ} 24^{\prime} 39^{\prime \prime S}$ 67³2'52"W, 2060 m, S. G. Beck et al. 29796 (K, LPB). Santa Cruz: Prov. Vallegrande, $2 \mathrm{~km}$ NW of Pucarillo, 1848'34"S, 6353'57"W, 1789 m, 23 May 2010, G. A. Parada $\mathcal{E}^{\circ}$ V. Rojas 2609 (MO, OXF, USZ).

CONSERVATION STATUS. Based on its extent of occurrence at about $11335 \mathrm{~km}^{2}$ this species would be classified as Vulnerable (VU) but this might well be an underestimate. The species is known from four collections in Bolivia (one from 1860), one from Peru (at Puno) and a handful from Brazil if Ipomoea federalis is accepted as conspecific. It is thus a very rare plant in South America. It appears to be annual and the recorded populations may not be permanent or large. There is obviously a need to refind this species and measure populations in the wild to assess its true conservation status.

PHENOLOGY. Like other annual species this flowers at the end of the summer rainy season in May and June. NOTES. Amongst Bolivian species utterly distinct because of the inflorescence of bracteate heads, the strongly veined bracteoles forming an involucre around the flowers.

85. Ipomoea marginisepala O'Donell (1950c: 490). Type: Argentina, Tucuman, Dep. Tafí, Cerro Aconquija, Sotelo 415 (holotype LIL).

Relatively weak, probably annual, twining herb, glabrous in all parts. Leaves petiolate, $3-9 \times 2.5-7 \mathrm{~cm}$, ovate, cordate with rounded auricles, acuminate to a fine point, margins undulate; petioles $3-8(-12) \mathrm{cm}$, somewhat warted. Inflorescence of pedunculate, axillary cymes, often with only 2 fully developed flowers; peduncle relatively stout, $2-15 \mathrm{~cm}$; bracteoles $1-3 \mathrm{~mm}$, deltoid, fugacious; secondary peduncles $0.8-1.5 \mathrm{~cm}$; pedicels mostly 20 - $30 \mathrm{~mm}$, slightly swollen upwards; sepals subequal, $5-6 \times 3 \mathrm{~mm}$, oblong-lanceolate, acute, dark green with white margin; corolla $2.5-4 \mathrm{~cm}$, funnelshaped, glabrous, tube white, yellowish inside, limb blue, 
c. $3 \mathrm{~cm}$ diam., unlobed. Capsule ovoid, $7 \mathrm{~mm}$ wide, $8 \mathrm{~mm}$ long, rostrate with a beak $3-5 \mathrm{~mm}$ long, glabrous; seeds $6-7 \mathrm{~mm}$ long, appearing glabrous but minutely tomentellous under a microscope. Fig. 30F.

DISTRIBUTION \& HABITAT. Locally frequent in the interAndean valleys of northern Argentina and southern Bolivia but scattered in occurrence and uncommon in both countries, mainly growing in the Chaco and in he arid lower slopes of the Río Grande valley and its tributaries. It is a plant of bare stony slopes in open bushland between about 1000 and $2000 \mathrm{~m}$ altitude. Its absence from Cochabamba Department is unexpected.

SPeCIMENS eXAMINed. BOLIVIA. Chuquisaca: Prov. Oropeza, Chuquichuqui, $1850 \mathrm{~m}, 5$ April 1996, J. R. I. Wood 10904 (HSB, K, NY); entre Chaco and Chuquichuqui, $18^{\circ} 50^{\prime} 51^{\prime \prime S} 65^{\circ} 20^{\prime} 80^{\prime \prime} \mathrm{W}, 1781 \mathrm{~m}, 3$ April, 2013, J. R. I. Wood E B. Williams 27730 (K, LPB, USZ). Potosi: Prov. Charcas, Calahuta, Río Caine basin, 18 04'08"S 6545'21"W, 2025 m, 13 April 2003, L. Rico $\mathcal{E}^{\circ}$ Windsor-Shaw 1634 (K, MO, NY). Santa Cruz: Sierra de Santa Cruz, May 1892, O. Kuntze s.n. (NY, US); Prov. Caballero, $7 \mathrm{~km}$ N of Saipina, $18^{\circ} 00^{\prime} \mathrm{S} 64^{\circ} 36^{\prime} 15^{\prime \prime} \mathrm{W}, 1400$ 1600 m, 31 March 1994, J. Balcazar 367 (MO); Jardin de Cactaceae de Pulquina, 18 $10^{\circ} 35^{\prime \prime S} 64^{\circ} 42^{\prime} \mathrm{W}, 1584 \mathrm{~m}, 27$ Feb. 2006, N. Biggs $\mathcal{E}^{\circ}$ D. Zappi 70 (K, USZ); Anamal towards Culpina, 18 13'06"S 64²7'39"W, 1380 m, 21 March 2008 M. Mendoza et al. 2927 (K, USZ); 5 km E of Saipina towards Aiquile, $18^{\circ} 05^{\prime} 56^{\prime \prime} \mathrm{S} 64^{\circ} 21^{\prime} 36^{\prime \prime} \mathrm{W}, 1630 \mathrm{~m}$, M. Dematteis et al. 2371 p.p. (CTES). Prov. Cordillera, Pie de la Muela del Diablo, Boyuibe-Camiri, 20²3'41"S 6321'07"W, 994 m, 25 March 2013, J. R. I. Wood et al. 27631 (K, LPB, USZ). Prov. Vallegrande, camino de Vallegrande a Moro Moro, ladera que baja al Río Mizque, 18²8'02"S 64¹6'05"W, 1749 m, 29 March 2013, J. R. I. Wood et al. 27692 (K, LPB, USZ). Tarija: Prov. Gran Chaco, 20 - $25 \mathrm{~km}$ de Villamontes hacia Palos Blancos, $21^{\circ} 23^{\prime} 15^{\prime \prime S} 63^{\circ} 39^{\prime} 21^{\prime \prime W}, 706$ m, 24 March 2013, J. R. I. Wood et al. 27612 (K, LPB, USZ); Prov. O’Connor, Entre Rios - Cañadas, 1200 m, April 1978, M. Coro 1119 (LIL).

CONSERVATION STATUS. Least Concern (LC).

PHENOLOGY. Flowers at the end of the summer rainy season from March to May.

NOTES. Kessler et al. 6119 (LPB) from Loma Larga towards Masicuri in Vallegrande Province may belong here but differs in the presence of stiff trichomes on the calyx and in having somewhat toothed leaves. It requires further investigation.

Readily distinguished from all native species by its blue corolla and small, oblong-lanceolate, whitemargined sepals.

86. Ipomoea tricolor Cav. (Cavanilles 1795: 5). Type: [cultivated plant from Mexico], Cavanilles s.n. (holotype MA 475860).
Twining annual herb, glabrous in all parts, stems robust and often thick ( $4-5 \mathrm{~mm}$ broad). Leaves petiolate, $3-$ $12 \times 2-10 \mathrm{~cm}$, ovate, cordate with rather angular, nearly rounded auricles, apex acuminate, both surfaces glabrous; petioles $1.5-11 \mathrm{~cm}$. Inflorescence of pedunculate, few-flowered axillary cymes; peduncles $3-20 \mathrm{~cm}$, bracteoles $1-2 \mathrm{~mm}$, oblanceolate, early caducous; secondary peduncles $0.5-2.5 \mathrm{~cm}$, pedicels $1.5-3 \mathrm{~cm}$, spreading at a wide angle; sepals subequal, $5-7 \times 3 \mathrm{~mm}$, oblong-lanceolate, acute, dark green with white margin, inner slightly longer than the outer; corolla $5-7.5 \mathrm{~cm}$, funnel-shaped, glabrous, tube white, yellowish inside, limb blue, $4 \mathrm{~cm}$ diam. Capsule $10 \times$ $6 \mathrm{~mm}$, ovoid, glabrous, rostrate; seeds $7 \times 3 \mathrm{~mm}$, blackish, appearing glabrous but minutely tomentellous under a microscope. Fig. 30E.

DISTRIBUTION \& HABITAT. Widely cultivated in temperate and subtropical regions this species is apparently of Mexican/Caribbean origin. In Bolivia it is found as a cultivated plant in La Paz and Buenavista but is not naturalised.

SPeCIMenS eXAMINed. BOliVIA. La Paz: Prov. Murillo, cultivated in Calacota, $16^{\circ} 31^{\prime} \mathrm{S} 68^{\circ} 05^{\prime} \mathrm{W}, 3300 \mathrm{~m}, 20$ May 1988, J. Solomon 18363 (LPB, MO); ibid., J. Solomon 18365 (MO). Santa Gruz: Prov. Ichilo, Buenavista, 17²7'31"S 6339'22"W, 346 m, 27 July 2014, J. R. I. Wood Eं D. Soto 27960 (USZ).

CONSERVATION STATUS. Not evaluated (NE). It is a cultivated species in Bolivia.

Species 87 - 90. A small clade of mostly nightflowering species with three species in Bolivia, all of which have a tendency to produce soft fleshy spines on the stem.

87. Ipomoea parasitica (Kunth) G. Don (1838: 275). Convolvulus parasiticus Kunth (1818 [publ. 1819]: 103). Type: Venezuela, near Caracas, Humboldt $\mathcal{E}^{\circ}$ Bonpland s.n. (holotype P 00670753!).

Perennial twining herb to $7 \mathrm{~m}$; stem rather stout and with scattered soft spines, branches rigid. Leaves petiolate, $3-10 \times 2-9 \mathrm{~cm}$, ovate, cordate with rounded auricles, apex finely acuminate, abaxially paler, usually adaxially thinly pubescent, sometimes glabrous; petioles $3-5 \mathrm{~cm}$, puberulent. Inflorescence of pedunculate, axillary cymes; peduncles stout, $3-5 \mathrm{~cm}$; bracteoles $3 \mathrm{~mm}$, linear-lanceolate, caducous; secondary peduncles $4-6 \mathrm{~mm}$; pedicels $15-22 \mathrm{~mm}$, stout, thinly puberulent, spreading at a wide angle and often reflexed in fruit; sepals slightly unequal, broadly elliptic with wide scarious margins, outer $6-7 \times 5$ $\mathrm{mm}$, obtuse and mucronate, abaxially with a few hairs, inner sepals similar but rounded and mi- 
nutely mucronulate, glabrous; corolla sericeous in bud, 2.5 - $4 \mathrm{~cm}$ long, funnel-shaped, tube white outside, yellow inside, limb blue (drying pink), c. $3 \mathrm{~cm}$ diam., deeply lobed. Capsule $7-12 \times 5 \mathrm{~mm}$, glabrous, ovoid, acute above a small apical corona; seeds $6-7 \mathrm{~mm}$, brown, glabrous. Fig. 32A.

DISTRIBUTION \& HABITAT. Widely distributed in America from Mexico south to Bolivia but uncommon in South America. In Bolivia an uncommon weed of uncertain status growing on roadsides. It is locally frequent around San Javier.

SPECIMENS EXAMINED. BoliVIA. Santa Cruz: Prov. Ichilo, Buenavista, 19 Oct. 1972, J. Dorantes et al. 1710 (CTES); Prov. Nuflo de Chávez, $1 \mathrm{~km}$ de San Javier on road to Santa Cruz, 16 ${ }^{\circ} 16^{\prime} 50^{\prime \prime} \mathrm{S} 62^{\circ} 33^{\prime} 05^{\prime \prime} \mathrm{W}, 494 \mathrm{~m}$, 5 May 2007, M. Mendoza $\mathcal{F}^{2}$ Rivadineira 2431 (K, USZ); along roads leading to Los Altos and Los Los Tumbos at edge of San Javier, $16^{\circ} 16^{\prime} 31^{\prime \prime} \mathrm{S} 62^{\circ} 31^{\prime} \mathrm{W}, 521 \mathrm{~m}, 25$ July 2014, J. R. I.Wood E D. Soto 27944 (K, LPB, OXF, USZ).

CONSERVATION StATUS. Not evaluated (NE). This species may be an introduction.

PHENOLOGY. Uncertain but recorded in flower during the winter dry season.

NOTES. A rather fleshy plant with a blue, lobed corolla limb and, usually, soft spines on the stem. The ripe fruit is held on a recurved peduncle. Dried specimens are superficially very similar to Ipomoea tricolor with a blue corolla, white-margined sepals and similar divaricating pedicels but can be distinguished by the sericeous corolla buds and different sepals.

88. Ipomoea alba L. (Linnaeus 1753: 161). Type: India, Rheede, Hort Ind. Malabar 11: 103. t. 50 (1692), designated by Verdcourt in Hubbard \& Milne-Redhead (1963: 130).

I. bona-nox L. (Linnaeus 1762: 228), nom. illeg., superfluous name for I. alba L.

Vigorous scrambling or trailing plant, stems to $10 \mathrm{~m}$, glabrous, sometimes armed with soft spines. Leaves petiolate, $5-15 \times 4-14 \mathrm{~cm}$, ovate, sometimes lobed to about one third, acuminate to a fine hair point, cordate at the base, auricles sometimes with broad teeth; petioles 3-18 cm. Inflorescence of 1-3-flowered, pedunculate, axillary cymes; peduncles 2 - 9 (- 20) $\mathrm{cm}$, stout; bracteoles caducous, not seen; pedicels 5 $15 \mathrm{~mm}$, swollen below flower; sepals unequal, outer sepals $15-25 \times 4-6 \mathrm{~mm}$, lanceolate with a long awn $5-12 \mathrm{~mm}$ in length, green with white margins inner sepals $12-20 \mathrm{~mm}$ including a $2-5 \mathrm{~mm}$ long awn, ovate, whitish with green midrib; corolla with a cylindrical tube 5-12 cm long and a spreading, white limb 4 $5 \mathrm{~cm}$ in diam., glabrous. Capsule ovoid, c. $3 \mathrm{~cm}$ long, glabrous; seeds 11 - 13 mm long, glabrous. Fig. 32C.
DISTRIBUTION \& HABITAT. A pantropical weedy species, not certainly known as a native anywhere. In Bolivia widely distributed in disturbed damp bushy places, particularly along shaded tropical streams, mostly below about $1600 \mathrm{~m}$ where it behaves as if native. It is also cultivated growing in gardens as high as Sucre $(2800 \mathrm{~m})$ and Cochabamba $(2600 \mathrm{~m})$ as well as in the lowlands. The list of specimens below does not reflect the total distribution as cultivated plants are not included and collections are not known from areas where the plant is known to grow such as the Zongo Valley near La Paz.

SELECTED SPECIMENS OF 54 EXAMINED. BOLIVIA. Beni, Ballivian, Espiritu, Río Yacuma, 200 m, 1 Aug. 1981, S. G. Beck 5561 (LPB). Chuquisaca: Prov. Luis Calvo, Com. Monte Grande, 19²16'23"S 6350'03"W, 878 m, 3 April 2009, Winder 387 (HSB). Prov. Siles, Muyupampa to Incahuasi, $1600 \mathrm{~m}$, May 1959, M. Cardenas 5733 (US). Cochabamba: Prov. Chapare, bajando de Cochabamba, 1800 m, 17 June 1982, X. Menhofer 1362 (LPB). La Paz: Prov. Larecaja, Hac. Simaco. Camino a Tipuani, 500 m, Feb. 1920, O. Buchtien 5526 (GH, NY). Prov. Nor Yungas, $0.5 \mathrm{~km}$ below Coroico, 16 ${ }^{\circ} 11^{\prime} \mathrm{S} 67^{\circ} 43^{\prime} \mathrm{W}, 1750 \mathrm{~m}, 16$ May 1985, J. Solomon 13710 (LPB, MO). Prov. Saavedra, Río Camata, Yurilaya, $15^{\circ} 11^{\prime} \mathrm{S} 68^{\circ} 35^{\prime} \mathrm{W}, 1020 \mathrm{~m}, 1$ May 2003, F. Zenteno et al. 550 (LPB). Prov. Sud Yungas, $3 \mathrm{~km} \mathrm{~N}$ of Chulumani on road to La Asunta, $1600 \mathrm{~m}, 10$ July 1994, J. R. I. Wood (LPB, K). Pando: Prov. Manuripi, near San Silvestre, 20 Oct. 1989, S. G. Beck et al. 19555 (LPB). Santa Cruz: Prov. Germán Busch, Laguna Cáceres, $500 \mathrm{~m}$, NNE of Puerto Suárez, $18^{\circ} 58^{\prime} \mathrm{S} 57^{\circ} 47^{\prime} 30^{\prime \prime W}, 80 \mathrm{~m}, 5$ May 1990, R. Frey et al. 503 (K, MO, USZ). Prov. Florida, c. 0.5 km de Hierba Buena, sobre la carretera a Mairana, lado de un rio, 1758'55"S 6401'36"W, 1099 m, 11 April 2003, J. R. I. Wood et al. 19653 (BOLV, K, LPB, USZ). Prov. Ichilo $12 \mathrm{~km}$ WSW of Portachuelo on highway to Buenavista $17^{\circ} 24^{\prime} \mathrm{S} 63^{\circ} 30^{\prime} \mathrm{W}, 280 \mathrm{~m}, 11$ June 1998, M. Nee 49753 (LPB, NY, USZ). Prov. Ibañez, Barrio Macdonald, Santa Cruz, 1745'56"S 6311'11"W, 415 m, 9 May 2008, M. Nee 55632 (USZ). Prov. Nuflo de Chávez, Lomerío, 12 km N of Las Trancas $16^{\circ} 31^{\prime} 13^{\prime \prime} \mathrm{S}, 61^{\circ} 50^{\prime} 47^{\prime \prime} \mathrm{W}, 450 \mathrm{~m} 18$ June 1995, F. Mamani 896 (MO, NY). Prov. Santiesteban, Montero, Puente Taruma, Río Piraí, km 50 Santa CruzCochabamba highway, 5 May 1992, N. Saddi 143 (USZ). Prov. Velasco, San José de Campamento, $15^{\circ} 09^{\prime} 20^{\prime \prime S}$ 6059'29"W, 230 m, 9 May 1996, R. Guillén Ė Lazo 4306 (LPB, MO, USZ). Tarija: Prov. Arce, $12.7 \mathrm{~km}$ S of Naranjo Agrío on road to Bermejo, 22 $22^{\prime} \mathrm{S} 64^{\circ} 29^{\prime} \mathrm{W}, 21$ - 23 April 1983, J. Solomon 9942 (MO). Prov. O'Connor, Com. Salinas, $21^{\circ} 48^{\prime} 24^{\prime \prime} \mathrm{S} 64^{\circ} 23^{\prime} 05^{\prime \prime W}, 932$ m, 2 April 2006, M. Serrano et al. 7608 (LPB).

CONSERVATION STATUS. Least Concern (LC).

PHENOLOGY. Although it has been collected in flower in almost every month of the year, it is most commonly found in flower at the end of the 



Fig. 32. A Ipomoea parasitica; B I. muricata; C I. alba (limb); D I. rubriflora; E I. hederifolia. PHOTOS: A, C JOHN WOOD; B, D - E BETH WILLIAMS.

summer rainy season from February to July. The flowers open at night and collapse early in the morning except on cloudy days.
NOTES. Unmistakeable when in flower but fruiting material is difficult to distinguish from Ipomoea muricata except by the longer aristate points of the sepals. 
89. Ipomoea muricata (L.) Jacq. (Jacquin 1798: 40). Convolvulus muricatus L. (Linnaeus 1767: 44). Type: India, Broad s.n. (Linn 218.18, lectotype, designated by Verdcourt in Hubbard \& Milne-Redhead (1963: 130)). Ipomoea turbinata Lag. (Lagasca y Segura 1816: Pl. 10), nom. illeg., superfluous.

Vigorous annual climbing or trailing plant; stems stout, armed with soft herbaceous spines. Leaves petiolate, 7 - 18 $\times 6-17 \mathrm{~cm}$, ovate or, rarely, 3-lobed, cordate with rounded auricles, apex shortly acuminate, glabrous; petioles $3-15$ $\mathrm{cm}$. Inflorescence of $1-2(-5)$-flowered, pedunculate cymes; peduncles $2.5-20 \mathrm{~cm}$, usually long, but, if short, commonly with soft spines; bracteoles caducous; pedicels $1.5-4.5 \mathrm{~cm}$, stout and strongly swollen upwards; sepals unequal, accrescent in fruit, glabrous, white with green midrib, outer 10 - $14 \mathrm{~mm}$, narrowly ovate, attenuate into a point up to $7 \mathrm{~mm}$ long, inner $7-12$ $\mathrm{mm}$, broadly ovate, abruptly narrowed to an awn 3 $4 \mathrm{~mm}$ long; corolla dark lilac, $5-6 \mathrm{~cm}$ long, glabrous, tube narrowly cylindrical below but widened to $10 \mathrm{~mm}$ below limb, limb c. $4 \mathrm{~cm}$ diam., spreading, unlobed. Capsule ovoid, $1.5-2 \mathrm{~cm}$ long and wide, glabrous, rostrate, the persistent style c. $3 \mathrm{~mm}$ long; seeds 8 $10 \mathrm{~mm}$ long, glabrous. Fig. 32B.

DISTRIBUTION \& HABITAT. Scattered throughout the tropics but rarely abundant. In Bolivia it is doubtfully native and grows as a plant of disturbed bushy places mostly around the borders of the Chaco.

SPECIMEnS eXAMIned. BOliviA. Chuquisaca: Prov. Sud Cinti, Cañon Verde, sector Las Abras, Culpina, $21^{\circ} 05^{\prime} \mathrm{S}$ $64^{\circ} 14^{\prime} \mathrm{W}, 1170 \mathrm{~m}$, A. Carretero 1699 (HSB); NW de Com. Orocote entre los ríos Limonal y Cochayo, 2047'S 642' 'W, 1650 m, 29 April 2005, R. Lozano et al. 1183 (MO). Santa Cruz: Prov. Chiquitos, Santiago de Chiquitos village, $18^{\circ} 20^{\prime} 22^{\prime \prime S} 59^{\circ} 35^{\prime} 49^{\prime \prime} \mathrm{W}, 614 \mathrm{~m}, 21$ April 2013, J. R. I. Wood E B. Williams 27904 (K, LPB, USZ). Prov. Cordillera, Alto Parapeti, Hac. Yapuimbia, 800 m, 5 Jan. 1984, R. Chávez de Michel 261 (LPB). Prov. Velasco, PNNKM, Los Fierros, 14³3'S 6044'W, 200 m, 20 July 1993, R. C. Quevedo et al. 2570 (BOLV, CTES, LPB, MO, USZ); $30 \mathrm{~km}$ from Santa Rosa de la Roca on road to Piso Firme, 15 37'34"S 61 $31^{\circ} 12^{\prime \prime} W, 361$ m, 13 April 2013, J. R. I. Wood et al. 27799 (LPB, OXF, USZ); $20 \mathrm{~km} \mathrm{~N}$ of Carmen Ruiz on road to San José Campamento, 1552'53"S 6101'46"W, 283 m, 14 April 2013, J. R. I. Wood et al. 27838 (K, LPB, USZ). Tarija: Prov. Gran Chaco, Cototo, 7 km E of Villamontes, 450 m, 11 April 1977, A. Krapovickas E A. Schinini 31182 (CTES, MO). Prov. O'Connor, $5 \mathrm{~km} \mathrm{~N}$ of Entre Rios sobre camino a Villamontes, $21^{\circ} 28^{\prime} 54^{\prime \prime S} 64^{\circ} 10^{\prime} 04^{\prime \prime} \mathrm{W}, 1260 \mathrm{~m}$, 12 April 2008, M. Atahuachi et al. 1519 (BOLV).

CONSERVATION STATUS. Least Concern (LC).

PHENOLOGY. Like other annuals this species flowers at the end of the rainy season around April - May. Flowers open at night.
NOTES. Commonly confused with Ipomoea alba but when flowering easily identified by the shorter dark lilac corolla which is widened below the limb. In fruit more difficult to separate but the aristate tip of the inner sepals is only $2-3 \mathrm{~mm}$ long.

Species 90 - 92. Leaves often toothed; sepals often white-margined. Corolla blue with pale tube.

90. Ipomoea aristolochiifolia G. Don (1838: 277). Type: Venezuela, Humboldt $\mathcal{E}^{\circ}$ Bonpland (holotype $\mathrm{P}$ 00670751!).

Ipomoea oocarpa Benth. (Bentham 1844 [publ. 1845]: 136). Type: Ecuador, Guayaquil, Sinclair s.n. (holotype K!).

Ipomoea tuerckheimii Vatke ex Donn. Sm. (Donnell Smith 1905: 8). Type: Guatemala, von Tuerckheim 386 (isotypes GH!, P, US).

Slender twining annual herb, stems shortly pilose or glabrous. Leaves petiolate, $1.5-6 \times 1-3.5 \mathrm{~cm}$, ovatedeltoid, narrowed to an acuminate and mucronate apex, base very narrowly cordate often with overlapping rounded auricles, margin often with a few teeth, ciliolate, adaxially glabrous, abaxially paler, the veins puberulent; petioles $0.5-5.5 \mathrm{~cm}$, glabrous to sparsely pilose. Inflorescence of 1 - 3(-6)-flowered, axillary, pedunculate cymes; peduncles $2.5-6 \mathrm{~cm}$, puberulent, very slender, often curved, arising through the sinus of the leaf base; bracteoles $1-1.5 \mathrm{~mm}$, triangular-lanceolate; pedicels mostly 5-10 mm, very slender, glabrous; calyx lanceolate in outline, sepals subequal, often warted on exterior near base but otherwise glabrous, $3-5 \times 1.5-2 \mathrm{~mm}$, oblonglanceolate, obtuse, mucronate, dark green with pale scarious margin; corolla $1.5-2.5 \mathrm{~cm}$, campanulate, tube white, limb blue (drying pink), very shallowly lobed, 1.2 $1.8 \mathrm{~cm}$ diam. Capsule glabrous, ovoid, the style often persistent as a rostrate tip, seeds puberulent. Fig. 33B.

DISTRIBUTION \& HABITAT. Widely distributed through the Americas, principally in the mountains of Central America and the Andes and absent from the drier regions and never very abundant. In Bolivia, scattered on moderately humid Andean slopes, 800 - $2300 \mathrm{~m}$ but most common in the Yungas of La Paz. It appears to be absent from the wetter escarpment slopes of the Chapare region. Map 20.

SELECTED SPECIMENS OF 24 EXAMINED. BOLIVIA. Chuquisaca. Prov. Boeto, bajado al valle del Río Grande de Nuevo Mundo, 18 56'16"S 64¹6'49"W, 1603 m, 27 March 2013, J. R. I. Wood et al. 27660 (K, LPB, USZ). Prov. Luis Calvo, Serranía de Iñao, Canton Ticucha, 19³1'44"S 6345'49"W, $820 \mathrm{~m}, 28$ May 2009, J. A. Peñaranda $\mathcal{E}^{\circ} J$. G. Tudela 924 (MO, OXF). Prov. Tomina, Thiumayo, valle del Río Azero, 19³5'28"S 6405'17"W, 1093 m, 26 
March 2013, J. R. I. Wood et al. 27651 (K, LPB, OXF, USZ). Prov. Zudañez, c. $2 \mathrm{~km} \mathrm{~S}$ of Rodeo on road to Zudañez from Redención Pampa, 2100 m, 22 March 1998, J. R. I. Wood Ẽ M. Serrano 13396 (K, LPB). La Paz: Prov. Muñecas, Carpa, al lado de la carretera y Río Charazani, $15^{\circ} 12^{\prime} 47^{\prime \prime} \mathrm{S} 68^{\circ} 49^{\prime} 34^{\prime} \mathrm{W}, 1900 \mathrm{~m}, 5$ May 2005, A. Fuentes E $R$. Cuevas 7969 (BOLV, LPB, $\mathrm{MO})$. Prov. Murillo, Zongo Valley, $16^{\circ} 07^{\prime} \mathrm{S} 68^{\circ} 05^{\prime} \mathrm{W}, 2300$ m, 20 Jan. 1985, J. Solomon 13130 (FTG, LPB, MO). Prov. Nor Yungas, Polopolo, Coroico, 1100 m, Oct. \& Nov. 1912, O. Buchtien 3879 (E, NY, US). Prov. Sud Yungas, debajo Pariguaya, Apincaya, Río Chimgamayu, 16³8'S 67³7'W, 2018 m, 7 April 2012, S. G. Beck 32842 (K, LPB). Potosi: Prov. Charcas, Torotoro, Cañon el Vergel, al fondo, $18^{\circ} 04^{\prime} 14^{\prime \prime} \mathrm{S} 65^{\circ} 27^{\prime} 06^{\prime \prime} \mathrm{W}, 2100 \mathrm{~m}, 24$ March 2005, J. R. I. Wood et al. 21968 (K, LPB). Santa Cruz: Prov. Florida, Achiras Camping, $18^{\circ} 09^{\prime} \mathrm{S} 63^{\circ} 49^{\prime} \mathrm{W}$, 1330 m, 16 April 1998, M. Nee et al. 49024 (NY). Prov. Vallegrande, Valle de Piraimiri, camino vecinal al sur, $1.5 \mathrm{~km}$ del camino principal, $18^{\circ} 39^{\prime} 14^{\prime \prime S}$ 6358'41"W, 1616 m, 4 March 2005, J. R. I. Wood et al. 21764 (K, LPB, USZ). Tarija: Prov. O’Connor, Chiquiacá, 4 April 2004, K. Fiebrig 2753 (BM, E, GH, K, P, US).

CONSERVATION STATUS. Least Concern (LC).

PHENOLOGY. Flowers at the end of the summer rainy season from March to May.

NOTES. Readily recognised by the delicate habit, small blue flowers, warted sepals with white margins and, particularly by the peduncle which passes through the sinus of the leaf base. It is commonly confused with Ipomoea dumetorum but that species has dark spots on the sepals, pink flowers and the peduncle never passes through the leaf sinus.

91. Ipomoea odontophylla $J . R$. I. Wood E $R$. W. Scotland, sp. nov. Type: Bolivia, Santa Cruz, Prov. Florida, bajando c. $3 \mathrm{~km}$ de La Yunga de Mairana, hacia el puesto de los guardeparques, J. R. I. Wood, M. Mendoza $\mathcal{E}^{2}$ C. Antezana 21431 (holotype USZ; isotypes $\mathrm{K}, \mathrm{LPB})$.

http://www.ipni.org/urn:lsid:ipni.org:names:77148135-1

Twining perennial reaching $5 \mathrm{~m}$ in height, stems glabrous, pale brown. Leaves petiolate, $6-13 \times 4-$ $10 \mathrm{~cm}$, ovate, deeply cordate with rounded auricles, apex acute to shortly acuminate, mucronate, margin denticulate with acute teeth, adaxially pubescent on the veins with scattered hairs on the intercostal areas, abaxially pubescent, veins prominent; petioles $3-8 \mathrm{~cm}$, sparsely pubescent but the widened base strongly pubescent. Inflorescence of 1 - 5-flowered, pedunculate axillary cymes; peduncles $2.5-6 \mathrm{~cm}$ long, glabrous; bracteoles 1 $2 \times 0.5 \mathrm{~mm}$, very narrowly lanceolate; pedicels $10-25 \mathrm{~mm}$, notably thickened upwards and differing somewhat in texture from the peduncles, glabrous or with a few hairs at base of calyx; sepals subequal, outer $7 \times 3-4 \mathrm{~mm}$, lanceolate to ovate, acute or subacute, glabrous, margin scarious, inner sepals slightly larger, $8 \times 4-5 \mathrm{~mm}$, ovate to suborbicular, rounded, scarious except near base; corolla $4-5.5 \mathrm{~cm}$, funnel-shaped, glabrous, tube white, limb blue, drying pink, c. $3.5 \mathrm{~cm}$ diam., shallowly lobed; stamens included, slightly unequal, glabrous apart from the thinly pilose base, shorter filaments $15-16 \mathrm{~mm}$, longer $17-18$ $\mathrm{mm}$, anthers $4 \mathrm{~mm}$; style $3 \mathrm{~cm}$, glabrous, stigma weakly 2lobed. Capsule $16 \times 13 \mathrm{~mm}$, ovoid, glabrous, rostrate, the mucro c. $3 \mathrm{~mm}$ long; seeds $9 \times 4 \mathrm{~mm}$, oblong in outline, brown, glabrous. Fig. 34 .

RECOGNITION. Molecular studies show that this species is sister to Ipomoea aristolochiifolia (Williams et al., in prep.) and resembles it in its blue corolla, which dries pink, white-margined sepals and rostrate capsule. However it is readily distinguished by its much larger denticulate leaves $4-5 \mathrm{~cm}$ in length, by the larger corolla and the peduncle that does not pass through the leaf sinus.

DISTRIBUTION \& HABITAT. A narrowly endemic species known only from the Yunga de Mairana in the Parque Nacional Amboró near Santa Cruz. It grows by tracks in somewhat disturbed cloud forest around 2200 2300 m. Map 10.

SPeCIMEnS eXAMINed. BoliviA. Santa Cruz: Prov. Florida, PN Amboró, $5.5 \mathrm{~km}$ of Camp. La Yunga, $18^{\circ} 03^{\prime} 05^{\prime \prime} \mathrm{S} 63^{\circ} 55^{\prime} \mathrm{W}, 2300 \mathrm{~m}, 29$ March 2002, M. Nee et al. 52029 (NY, USZ); La Yunga de Mairana, limites del Parque Amboró, 1802'42"S 6355'34"W, 2260 m, 10 April 2003, J. R. I. Wood et al. 19636 (K, LPB, USZ); bajando c. $3 \mathrm{~km}$ de La Yunga de Mairana, hacia el puesto de los guardeparques, $18^{\circ} 04^{\prime} 05^{\prime \prime S} 63^{\circ} 55^{\prime} 06^{\prime \prime W}, 2198 \mathrm{~m}$, 23 Jan. 2005, J. R. I. Wood et al. 21431 (K, LPB, USZ).

CONSERVATION STATUS. Based on the extent of its known occurrence this species should be classified provisionally as Critically Endangered (CR). All collections come from the same area which lies at the edge of the Amboró National Park. The area is relatively well-studied and other populations have not been found. Although the area is protected, it may be vulnerable to climate change resulting, for example, in fire or other damage. The population merits careful monitoring.

PHENOLOGY. Found in flower from January to April. ETYMOLOGY. The epithet "odontophylla" refers to the toothed leaves, which are an unusual feature in Ipomoea.

92. Ipomoea huayllae $J$. R. I. Wood $\mathcal{E} R$. W. Scotland, sp. nov. Type: Bolivia, La Paz, Prov. Tamayo, ANMI Apolobamba, camino Pelechuco-Apolo, entre Puente Coronara y Hac. Corapara, A. Fuentes E $\mathcal{H}_{\text {H. Huaylla }}$ 12939 (holotype LPB; isotypes K, MO, OXF).

http://www.ipni.org/urn:Isid:ipni.org:names:77148136-1

Twining herb, possibly annual, stems thinly pubescent with spreading hairs when young, glabrescent when 

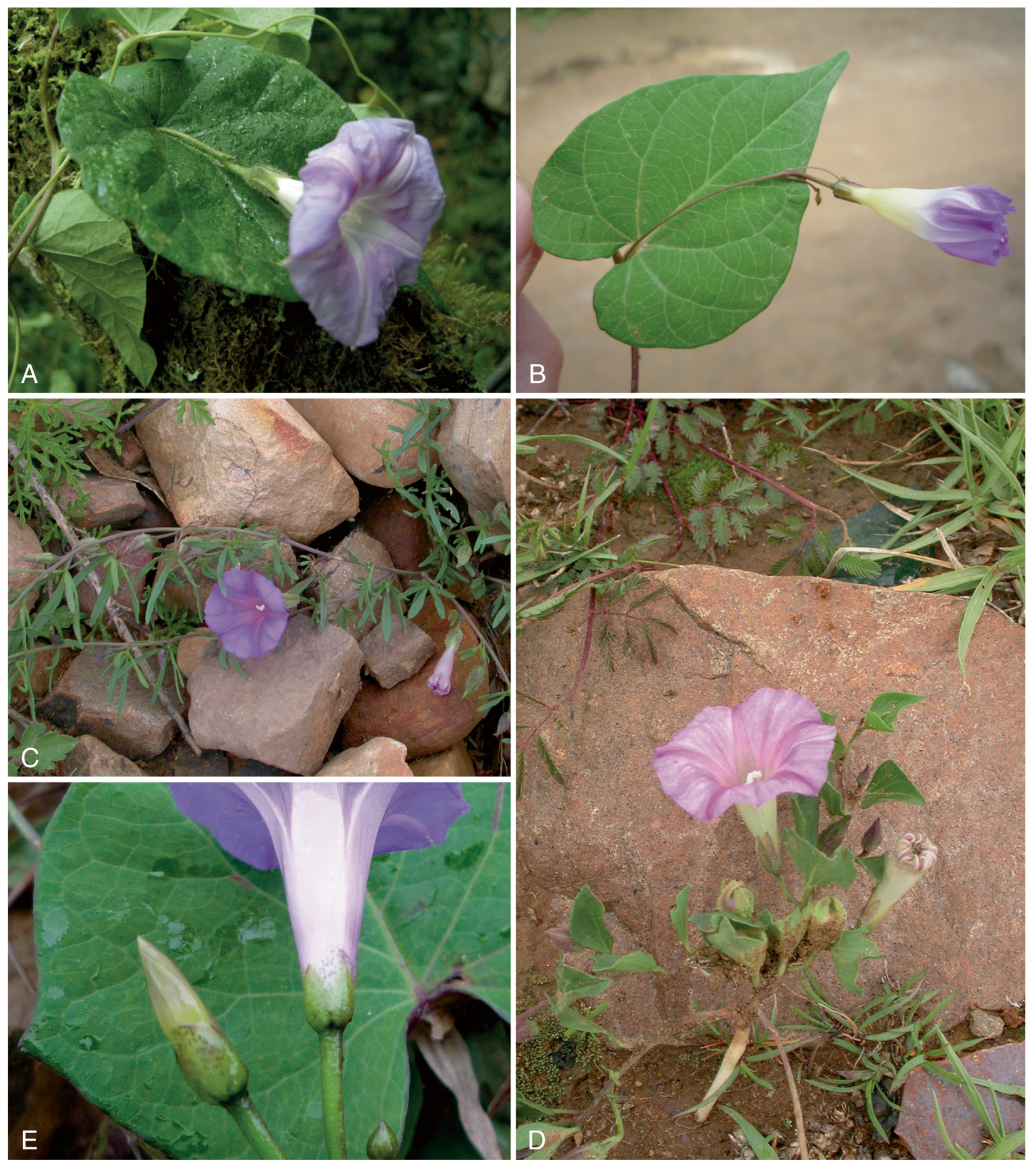

Fig. 33. A Ipomoea huayllae; B I. aristolochiifolia; C I. plummerae; D I. plummerae f. adiantifolia; E I. dumetorum. PHOTOS: A ALFREDO FUENTES; B, E BETH WILLIAMS; C - D DARWIN INITIATIVE PROJECT 162/11/010.

older. Leaves petiolate, $6-10 \times 3-7 \mathrm{~cm}$, ovate, acute and finely mucronate, base cordate with rounded auricles, margin entire to slightly undulate; petioles $1-7 \mathrm{~cm}$, pubescent. Inflorescence of solitary axillary flowers (rarely a second, non-developing flower present); peduncle, $3-5.5 \mathrm{~cm}$, pubescent, penetrating leaf sinus; bracteoles $1 \times 0.25 \mathrm{~mm}$, deltoid, obtuse, green with white margins; pedicels $6-12 \mathrm{~mm}$, thickened upwards, pubescent; sepals slightly unequal, outer $6 \times 2.5 \mathrm{~mm}$, acute, green, pubescent, the hairs with swollen bases, margins scarious, glabrous, inner sepals $7-9 \times 4 \mathrm{~mm}$, broadly oblong-elliptic, minutely mucronate, only the middle green and pilose, the margins and apex scarious, glabrous; corolla glabrous, 


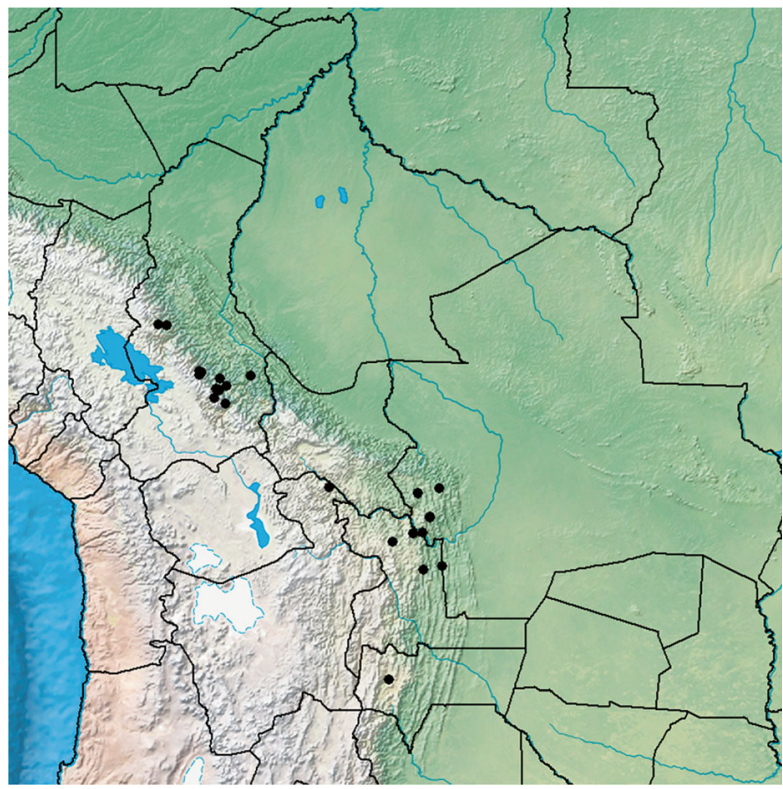

Map 20. Distribution of Ipomoea aristolochiifolia ( ), a typical Andean species of middle altitudes.

$4 \mathrm{~cm}$ long, funnel-shaped with the rim of the limb recurved, pale blue with whitish tube and midpetaline bands, limb c. $4 \mathrm{~cm}$ diam., unlobed, midpetaline bands ending in a point; filaments glabrous except glandular-pilose base, unequal, longer c. $12 \mathrm{~mm}$, shorter c. $6 \mathrm{~mm}$; anthers oblong, $2.5 \times 0.75 \mathrm{~mm}$; style $16 \mathrm{~mm}$, glabrous, stigma not seen. Capsule glabrous, ovoid, $14-15 \times 11 \mathrm{~mm}$, seeds $7 \times 6 \mathrm{~mm}$, flattened-ovoid, dark brown, superficially glabrous but minutely pilosellous under a microscope. Figs 33A, 35.

RECOGNITION. Closely related to Ipomoea aristolochiifolia as apparent from the peculiar placement of the peduncle in the leaf sinus and confirmed by molecular studies but immediately distinguished by the larger corolla $4 \mathrm{~cm}$ long (not $1.5-2.5 \mathrm{~cm}$ ), the limb $4 \mathrm{~cm}$ diam. Additionally the sepals are pubescent and the leaves larger and pubescent beneath.

DISTRIBUTION \& HABITAT. Endemic to Bolivia and only known from Yungas cloud forest with secondary vegetation between $2100-2300 \mathrm{~m}$ in the ANMI Apolobamba. Map 10.

SPeCimens eXAMined. BoliviA. La Paz: Prov. Tamayo, ANMI Apolobamba, camino Pelechuco-Apolo, entre Puente Coronara y Hac. Corapara, 1446'21"S 68 59'29"W, 2320 m, 12 June 2008, A. Fuentes $\mathcal{F}^{\circ} H$. Huaylla 12939 (K, LP, MO, OXF); ANMI Apolobamba, camino Pelechuco-Apolo, Hac. Coronara, hacia Jocotika, bordeando el Río Pelechuco, 2158 m, 11 June 2008, H. Huaylla et al. 2754 (MO, OXF).

CONSERVATION STATUS. Data deficient (DD). Based on the extent of its known occurrence this species would be classified as Critically Endangered (CR) but we have no information about the size of the population and it may well have been overlooked elsewhere. It is reassuring that its only known stations are within a protected area.

PHENOLOGY. Collected with flowers in June.

ETYMOLOGY. This species is named for Hibert Huaylla, who made the first collection of this species. He is one of the new generation of Bolivian botanists with special interest in ferns and petaloid monocots. He has accompanied John Wood on numerous field trips over more than fifteen years and is an outstanding field botanist.

Species 93 - 97. The Quamoclit group. This clade has long been accepted as a distinct group. Its most distinct feature is the presence of an awn on the dorsal surface of the sepals. Additionally the corolla is red, yellow or orange and in most species the corolla tube is narrowly cylindrical. The ovary is 4-locular and the capsule up to 4-seeded. The seeds are tomentellous, the hairs equal or unequal in length but long marginal hairs always absent.

93. Ipomoea lobata (Cerv.) Thell. (Thellung 1919: 775). Mina lobata Cerv. (Cervantes 1824: 3). Type: Cultivated plant from Mexico (holotype G).

Annual twining herb, stem usually glabrous. Leaves petiolate, $3-12 \times 2.5-10 \mathrm{~cm}$, ovate or, more commonly 3-lobed to about half way, base cordate with rounded auricles, apex shortly acuminate, obtuse and mucronate, near glabrous but sometimes puberulent on the veins beneath, abaxially paler; petioles $2-5$ $\mathrm{cm}$. Inflorescence of long-pedunculate axillary cymes appearing to form an elongate bifurcate raceme; peduncles $(5-) 10-16(-30) \mathrm{cm}$; rhachis above branching point, (2 -) $8-12 \mathrm{~cm}$; bracteoles $1-2 \mathrm{~mm}$, linear-lanceolate, moderately persistent; pedicels slender, 2 - $6 \mathrm{~mm}$, longer below; sepals dissimilar, glabrous or, occasionally, thinly pilose, outer oblong-ovate, $2-3 \times$ $1.5 \mathrm{~mm}$ with terminal awn $2-4 \mathrm{~mm}$ long, inner sepals with broader base, elliptic, $3-3.5 \times 2 \mathrm{~mm}$ and awn $2-$ $4 \mathrm{~mm}$ long; corolla tubular, curved, suburceolate, 1.8 $2.5 \mathrm{~cm}$ long, yellow, red or orange, limb formed of 5 small tooth-like lobes; stamens strongly exserted; style exserted. Capsules subglobose, $7 \mathrm{~mm}$ diam., glabrous; seeds $4 \mathrm{~mm}$ long, pubescent with hairs in patches.

DISTRIBUTION \& HABITAT. This species is probably of Mexican origin but is widely cultivated and occasionally naturalised in the Americas.

SPECIMENS EXAMINED. BOLIVIA. La Paz: Prov. Nor Yungas, Coroico, pie de Uchumachi, $16^{\circ} 12^{\prime} 06^{\prime \prime} \mathrm{S} 67^{\circ} 43^{\prime} 48^{\prime \prime} \mathrm{W}$, 1890 m, 2 Nov. 2006, S. G. Beck 29599 (LPB).

CONSERVATION STATUS. Not evaluated. It only occurs in cultivation or as an escape. 




Fig. 34. Ipomoea odontophylla. A habit; B flowering shoot; C stem; D adaxial leaf surface; E abaxial leaf surface; F outer sepal; G middle sepal; $\mathbf{H}$ inner sepal; J corolla opened out to show stamens; $\mathrm{K}$ stamen; L ovary and style; $\mathrm{M}$ capsule; $\mathrm{N}$ seed. A - L from Wood et al. 21431; M - N from Nee et al. 52029. DRAWN BY ROSEMARY WISE. 


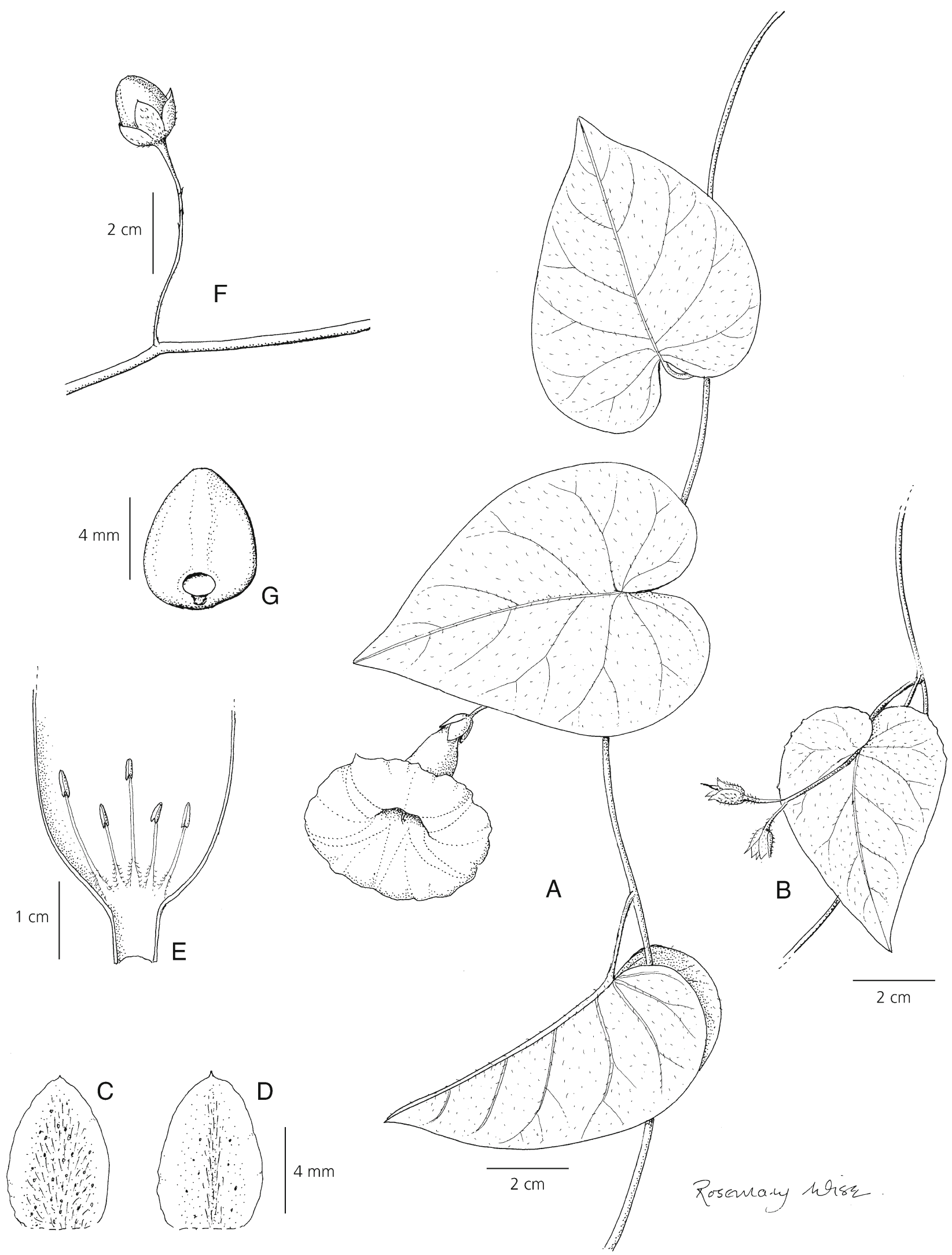

Fig. 35. Ipomoea huayllae. A habit; B inflorescence showing position of peduncle; C outer sepal; D inner sepal; E corolla opened out to show stamens; F capsule; G seed. A, G - F from Fuentes et al. 12939; B - E from Huaylla et al. 2754. DRAWN BY ROSEMARY WISE. 
PHENOLOGY. Found in flower in November.

NOTES. Quite unlike other species of Ipomoea on account of its raceme-like inflorescence combined with aristate sepals and tubular corolla, the limb replaced with five teeth.

94. Ipomoea quamoclit $L$. (Linnaeus 1753: 159). Type: India, Herb. Clifford 66, Ipomoea 1 (BM -000558077), designated by Biju 2002 [publ. 2003]: 755)

Twining annual herb, plant completely glabrous. Leaves shortly petiolate, $1-7(-9) \times 0.8-7 \mathrm{~cm}$, ovate-elliptic in outline, deeply pinnatifid to the main vein, the segments linear, acute, mostly $8-15$ pairs; petioles 0.5 - $3(-4.5) \mathrm{cm}$, often with pseudostipules at base. Inflorescence of 1 (-5)-flowered axillary, pedunculate cymes; peduncles $1-5(-14) \mathrm{cm}$; bracteoles elliptic, c. $1 \mathrm{~mm}$ long; pedicels $8-20 \mathrm{~mm}$, swollen upwards; sepals slightly unequal, oblong-elliptic, obtuse and very shortly mucronate, the mucro $<1 \mathrm{~mm}$ long, margins scarious, the outer $4-6 \times 2-3 \mathrm{~mm}$, the inner c. $1 \mathrm{~mm}$ longer; corolla usually red, hypocrateriform, the tube $2-3 \mathrm{~cm}$ long, widened upwards, the limb c. $2 \mathrm{~cm}$ diam., deeply lobed with acute lobes; stamens exserted. Capsule ovoid, 7 $9 \mathrm{~mm}$ long, rostrate, glabrous; seeds c. $5 \mathrm{~mm}$, rostrate with hairs in patches.

DISTRIBUTION \& HABITAT. Widely cultivated and sometimes naturalised throughout the tropics. In Bolivia scattered throughout the tropical lowlands south to the Santa Cruz area. Most records are certainly of cultivated plants, but it is occasionally naturalised as around villages north of Santa Rosa de la Roca and probably elsewhere. The cited localities show a strong preference for the humid lowlands and do not reflect its frequency as a cultivated plant.

SELECTED SPECIMENS OF 19 EXAMINED. BOLIVIA. Beni: Prov. Ballivian, Est. Biologica del Beni, Com. Cero Ocho, 14 $4^{\circ} 30^{\prime} \mathrm{S} 66^{\circ} 37^{\prime} \mathrm{W}, 200$ m, 24 Jan. 1995, J. Balderrama 361 (LPB, NY, USZ). Cochabamba: Prov. Carrasco, Est. Experimental, Valle de Sacta, $17^{\circ} 05^{\prime} \mathrm{S} 64^{\circ} 40^{\prime} \mathrm{W}, 288 \mathrm{~m}, 14$ - 19 Oct. 1991, T. J. Killeen et al. 3498 (ARIZ, BOLV, LPB, MO, USZ). Prov. Chapare, TIPNIS (Isibore-Sécure), Com. Sanandita, $16^{\circ} 32^{\prime} \mathrm{S} 65^{\circ} 29^{\prime} \mathrm{W}, 210 \mathrm{~m}, 24$ March 2005, E. Thomas $\mathcal{E}^{\circ}$ Berdeja 1472 (LPB). La Paz: Prov. Larecaja, Mapiri, San Carlos, 650 m, August 1907, O. Buchtien 1478 (US). Pando: Prov. Suárez, Provenir, 21 Jan. 1983, F. Fernandez Casas Ẽ A. Susanna 8352 (LPB, MA, MO, NY). Santa Cruz: Ibañez, 340 m, June 1892, O. Kuntze s.n. (NY). Prov. Velasco, PNNKM, Camp. Los Fierros, 14 33'28"S 6055'51"W, 200 m, 18 March 1997, L. Sanchez et al. 415 (LPB, NY, USZ); 10 - 15 km from Santa Rosa de la Roca on the road to Piso Firme, 15 47'17"S 61 ${ }^{\circ} 34^{\prime} 39^{\prime \prime W}, 348$ m, 13 April 2013, J. R. I. Wood et al. 27793 (K, LPB, USZ).

CONSERVATION STATUS. Least concern (LC).
PHENOLOGY. Found in flower in most months of the year.

95. Ipomoea hederifolia L. (Linnaeus 1759: 925). Type: "Ipomoea foliis cordatis" in Plumier in Burman, Pl. Amer. 4: 82, t. 93, f. 2 (1756), designated by O'Donell (1959a: 48).

Ipomoea coccinea auct., non L.

Twining annual, stems glabrous or thinly pilose. Leaves petiolate, $2-12 \times 2-11 \mathrm{~cm}$, variable in shape, most commonly 3-lobed to about half way, sometimes very shallowly lobed so leaf coarsely 3 - 5-dentate, sometimes simply ovate, apex acute or obtuse, mucronate, base cordate with obtuse auricles, glabrous to thinly pubescent; petioles mostly $1-6 \mathrm{~cm}$. Inflorescence of pedunculate, axillary cymes; peduncles $5-15 \mathrm{~cm}$ long, bracteoles ovate, c. $1 \mathrm{~mm}$, caducous; secondary peduncles $1-2.5 \mathrm{~cm}$; pedicels $3-12 \mathrm{~mm}$, remaining erect in fruit; sepals slightly unequal, oblong-elliptic, obtuse to rounded with a prominent awn, margins scarious, glabrous, outer sepals $1.5-3 \mathrm{~mm}$ with mucro mostly $2-5 \mathrm{~mm}$ long, inner slightly larger with broader scarious margins; corolla red, hypocrateriform, glabrous, the tube $2-4 \mathrm{~cm}$ long, slightly widened upwards, limb $1.8-2.5 \mathrm{~cm}$ diam., very shallowly lobed to entire, weakly spreading, acute; stamens exserted. Capsule $5-7 \mathrm{~mm}$, subglobose, lacking an apical mucro, glabrous; seeds $3-4 \mathrm{~mm}$ long, shortly tomentose. Fig. 32E.

DISTRIBUTION \& HABITAT. Common in tropical and subtropical America from the southern United States to Argentina; introduced into the Old World tropics. In Bolivia, a common plant of disturbed bushy places and secondary scrub below $1000 \mathrm{~m}$ (rarely reaching $1500 \mathrm{~m}$ in the Yungas of La Paz) but apparently absent from the more humid regions including the Chapare, Pando and much of the Beni as well as the drier areas of the Chaco and the inter-Andean valleys.

SELECTED SPECIMENS OF 60 EXAMINED. BOLIVIA. Beni: Prov. Ballivian, Est. Biologica del Beni, Com. Totaizal, 14³0'S 66³7'W, 200 m, 22 June 1995, J. Balderrama 583 (LPB, MO). Prov. Yacuma, Est. Biologica El Porvenir, $14^{\circ} 50^{\prime} \mathrm{S} 66^{\circ} 20^{\prime} \mathrm{W}, 250 \mathrm{~m}, 12$ June 1988 , E. Villanueva et al. 859 (F, LPB). Chuquisaca: Prov. Calvo, camino El Salvador-Algodonal, E side of Sierra Mandiyapecua, 20³1'S 6304'W, 890 m, 12 April 1993, E. Saravia et al. 11740 (LPB). La Paz: Prov. Inquisivi, entre Cahuata and Miguillas, $16^{\circ} 37^{\prime} 39^{\prime \prime} \mathrm{S}, 67^{\circ} 16^{\prime} 11^{\prime \prime} \mathrm{W}$, 1390 m, 13 Dec. 2003, T. Ortuño et al. 346 (K, LPB). Prov. Iturralde, Ixiamas, 275 m, 19 Dec. 1921, White 2320 (NY). Prov. Larecaja, Guanay, 4 Oct. 1993, Harrison 1 (LPB). Prov. Murillo, Huaranilla, Cañigueral 1215 (LPB). Prov. Nor Yungas, $3 \mathrm{~km}$ W of Pacallo along Río Huarinilla, $16^{\circ} 12^{\prime} \mathrm{S} 67^{\circ} 50^{\prime} \mathrm{W}, 1300 \mathrm{~m}, 6$ May 1990 , J. Solomon et al. 18973 (K, LPB, MO, USZ). Prov. Sud 
Yungas, Chulumani, Chimpa, 67 $31^{\prime} 40^{\prime \prime S} 16^{\circ} 26^{\prime} 48^{\prime \prime} \mathrm{W}$, 1436 m, 5 May 2007, D. Ibañez $\mathcal{E}$ R. Hurtado 465 (LPB). Santa Cruz: Prov. Germán Busch, Serranía de Mutún, $19^{\circ} 11^{\prime} 42^{\prime \prime S} 57^{\circ} 52^{\prime} 30^{\prime \prime} \mathrm{W}, 527 \mathrm{~m}, 9 \mathrm{March} 2008$, D. Villarroel et al. 2053 (USZ). Prov. Chiquitos, $2 \mathrm{~km}$ al este del desvío a Santa Cruz en el camino de Robore a Aguas Calientes, $18^{\circ} 21^{\prime} 05^{\prime \prime S} 59^{\circ} 36^{\prime} 08^{\prime \prime W}, 590$ m, 12 April 2008, J. R. I. Wood et al. 24424 (K, LPB, UB, USZ). Prov. Cordillera, sin datos, 14 April 1977, A. Krapovickas $\mathcal{E}$ A. Schinini 31312 (CTES). Prov. Florida, $6 \mathrm{~km}$ E of Bermejo, 18 $08^{\circ} 38^{\prime \prime} \mathrm{S}$ 633'ㄷ'ㄷ'W, 848 m, 11 April 2006, M. S. Ferrucci et al. 2644 (CTES, K). Prov. Guarayos, $10 \mathrm{~km}$ from Ascención towards San Ramón, $16^{\circ} 01^{\prime} 41^{\prime \prime} \mathrm{S} 63^{\circ} 05^{\prime} 37^{\prime \prime} \mathrm{W}, 14$ Sept. 2006, M. Mendoza et al. 2142 (K, USZ). Prov. Ibañez, Barrio Guaracal, $17^{\circ} 49^{\prime} 35^{\prime \prime} \mathrm{S} 63^{\circ} 12^{\prime} 44^{\prime \prime} \mathrm{W}, 410 \mathrm{~m}$, 4 July 1994, A. Fuentes 393 (BOLV, LPB, MO, NY, USZ). Prov. Ichilo, Res. Forestal El Choré, $16^{\circ} 46^{\prime} 54^{\prime \prime S}$, $64^{\circ} 13^{\prime} 53^{\prime \prime W}, 220$ m, 17 July 2005, A. Molina 17 (MO, OXF). Prov. Nuflo de Chávez, Cuatro Canadas, $17^{\circ} 16^{\prime} \mathrm{S} 62^{\circ} 15^{\prime} \mathrm{W}, 262 \mathrm{~m}, 28$ March 1996, J. Balcazar E Franco 451 (LPB, USZ). Prov. Sara, camino a Laguna Juan Chulo, $17^{\circ} 00^{\prime} 30^{\prime \prime} \mathrm{S} 63^{\circ} 43^{\prime} 13^{\prime \prime} \mathrm{W}, 250 \mathrm{~m}, 6$ Jan. 2009, G. A. Parada et al. 1380 (MO, OXF). Prov. Velasco, Bajo Paraguá, Cerro Pelao, 14³2'40"S $61^{\circ} 29^{\prime} 34 " \mathrm{~W}, 450 \mathrm{~m}, 11$ May 1994, T. J. Killeen $\mathcal{E} J$. Wellens 6274 (ARIZ, BOLV, LPB, MO, NY, USZ). Prov. Warnes, Las Barreras, Warnes, 375 m, 21 June 1980, F. E. Tollervey 2518 (K). Tarija: Gran Chaco, $22 \mathrm{~W}$ of Villamontes towards Tarija, 4 May 1983, A. Krapovickas \& A. Schinini 39175 (CTES, LPB)

CONSERVATION STATUS. Least concern (LC).

PHENOLOGY. Flowers predominantly at the end of the rainy season from February to June but there are collections of flowering plants from almost every month.

NOTES. The only red-flowered Ipomoea which is common in the lowlands. It can be recognised by the very short sepals and, in fruit, by the erect peduncle and muticous capsule. It has commonly been misidentified as I. coccinea L., a species which is endemic to the south east of the United States.

96. Ipomoea rubriflora O'Donell (1959a: 79). Type: Argentina, Cordoba, Dep. San Alberto, entre Mina Clavero y Nono, O'Donell E Rodríguez 708 (holotype LIL!).

Similar to Ipomoea hederifolia in habit, variability of leaf shape and general features of the inflorescence but more robust, the stems distinctly angled, glabrous except at nodes. Leaves usually glabrous or nearly so; sepals glabrous or pubescent, outer sepals oblong-obovate, $3-4 \mathrm{~mm}$; inner sepals $5-6$ $\mathrm{mm}$, corolla limb $2-3 \mathrm{~cm}$ diam., stamens very shortly exserted. Capsule strongly rostrate terminat- ing in a persistent mucro $3-5 \mathrm{~mm}$ long, the fruiting pedicel erect; seeds tomentose with hairs unequal in length those bordering the central groove longer. Fig. 32D.

DISTRIBUTION \& HABITAT. Only known from the dry inter-Andean valleys of Bolivia and northern Argentina. In Bolivia scattered in suitable habitats from Cochabamba south to the border with Argentina, mostly between 1500 and $2700 \mathrm{~m}$, but not very common. There are also isolated records from Yanacachi and Sorata in the Yungas dry valleys but it is obviously very rare and atypical of that region.

SELECTED SPECIMENS OF 30 EXAMINED. BOLIVIA. Chuquisaca: Prov. Azurduy, Torrepampa, $5 \mathrm{~km}$ NW of Com. San Pedro, $19^{\circ} 36^{\prime} 14^{\circ} \mathrm{S} 64^{\circ} 28^{\prime} 29^{\prime \prime} \mathrm{W}, 2180 \mathrm{~m}$, 27 April 2008, R. Lozano et al. 3173 (MO, OXF). Prov. Boeto, 5 - $10 \mathrm{~km}$ de Nuevo Mundo sobre el camino a Río Grande, $18^{\circ} 57^{\prime} 37^{\prime \prime S} 64^{\circ} 16^{\prime} 50^{\prime \prime} \mathrm{W}, 1866 \mathrm{~m}, 27$ March 2013, J. R. I. Wood et al. 27657 (K, LPB, OXF). Prov. Oropeza, Sucre-Pilcomayo, 2000 m, April 1933, M. Cardenas 575 (NY). Prov. Tomina, c. 4 km W of Padilla along road to Sucre, 2200 m, 11 April 1994, J. R. I. Wood 8306 (K, LPB). Cochabamba: Prov. Capinota, camino entre Parotani and Capinota, $17^{\circ} 36^{\prime} 10^{\prime \prime S} 66^{\circ} 17^{\prime} 7^{\prime \prime} \mathrm{W}, 2357 \mathrm{~m}, 27$ Feb. 2005, M. Mercado $\mathcal{E} \mathcal{O}^{2}$ A. Haigh (K). Prov. Cercado, Cerro San Pedro, 2680 m, 10 Jan. 1996, N. de la Barra 239 (BOLV). Prov. Mizque, Quioma silver mines, $2700 \mathrm{~m}$, 5 April 1939, W. J. Eyerdam 25205 (F, K). La Paz: Prov. Larecaja, Sorata, 2550 - 2700 m, 1861, G. Mandon 1485 p.p. (BM). Prov. Sud Yungas, Yanacachi, Nov. 1906, O. Buchtien 4677 (US). Santa Cruz: Prov. Caballero,

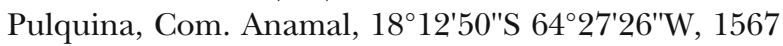
m, 1 April 2008, M. Garvizu E Muñoz 1089 (K, USZ). Prov. Florida, $18^{\circ} 24^{\prime} 00^{\prime \prime S} 64^{\circ} 01^{\prime} 12^{\prime \prime W}, 2200 \mathrm{~m}, 24$ May 1996, R. K. Brummitt et al. 19265A (LPB); Prov. Vallegrande, Choroquetal, $5 \mathrm{~km} \mathrm{~N}$ of Vallegrande, $18^{\circ} 28^{\prime} 07^{\prime \prime S}, 64^{\circ} 07^{\prime} 25^{\prime \prime} \mathrm{W}, 1932,17$ March 2003, M. Mendoza Eै R. M. Ledezma 530 (K, USZ). Tarija: Prov. Arce, $4 \mathrm{~km}$ de Padcaya hacia Tarija, $21^{\circ} 50^{\prime} \mathrm{S}$ 64ㄴㅁ'W, 1900 m, 16 March 1998, S. G. Beck et al. 26166 (LPB). Prov. Cercado, camino a Erquis, 1935 m, 25 Feb. 1986, E. Bastian 827 (LPB, USZ). Prov. Mendez, 23 April, 1991, M. Coro 114 (MO). Prov. O'Connor, Res. Nat. Tariquia, Serranía Nogal, $21^{\circ} 48^{\prime} 16^{\prime \prime} \mathrm{S}$ $64^{\circ} 20^{\prime} 51^{\prime \prime W}, 1008$ m, 27 March 2006, M. Serrano $\mathcal{E} J$ J. Villalobos 7436 (LPB).

CONSERVATION STATUS. Least concern (LC).

PHENOLOGY. Flowers at the end of the rainy season from February to May and very occasionally in other seasons.

NOTES. Ipomoea rubriflora is most easily distinguished from similar species by the erect, rostrate fruiting capsule.

Its presence in La Paz Department requires confirmation as there is some doubt whether the cited specimens were actually collected there. 
97. Ipomoea indivisa (Vell.) Hallier f. (Hallier 1922: 20) Convolvulus indivisus Vell. (Vellozo 1825 [1829]: 71). Type: Icon., Flora Flumenesis tab 50. (Vellozo 1827 [1831]), lectotype, designated here.

Very similar to Ipomoea hederifolia and I. rubriflora, differing from both in always having unlobed leaves which may be either entire or dentate. In habit, indumentum, sepal dimensions and rostrate capsule it is similar to I. rubriflora but in fruit it is easily distinguished by the reflexed fruiting pedicels. Flowering specimens can sometimes be impossible to separate but I. rubriflora often has 3-lobed leaves, whereas in I. indivisa the leaves are always unlobed.

TYPIFICATION. There is no known extant specimen that can be selected as a lectotype of Convolvulus indivisus so the plate is the only possible choice and is here designated as the lectotype. It is not a particularly good illustration but clearly shows an Ipomoea of the Quamoclit group with entire leaves, a persistent style resulting in a rostrate capsule and a deflexed fruiting pedicel.

DISTRIBUTION \& HABITAT. Ipomoea indivisa is common in southern Brazil and adjacent parts of Argentina and Uruguay but is less common in the Andean region. In Bolivia it is rare and there have been no collections for almost a hundred years apart from one doubtful record. It is likely that it has been overlooked rather than become extinct as it is superficially similar to I. hederifolia, which is common in the Yungas of La Paz. SPECIMENS EXAMINed. BOlIVIA. La Paz: Yungas, 1890, M. Bang 587 (F, GH, K, NY, RB). Prov. Larecaja, Hac. Simaco, Tipuani, 1400 m, Feb. 1920, O. Buchtien 5525 (GH, MO, US). Prov. Nor Yungas, Milluguaya, 1300 m, Dec. 1917, O. Buchtien 4246 (US). Prov. Sud Yungas, camino Yanacachi-Mocari, $16^{\circ} 25^{\prime} \mathrm{S} 67^{\circ} 45^{\prime} \mathrm{W}, 1650 \mathrm{~m}$, 28 Jan. 1989, R. Seidel 1461 — fruit immature (K, LPB). CONSERVATION STATUS. Data Deficient (DD). There are no recent collections of this species. It may be extinct but it is much more likely that it has been overlooked although it can never have been very common.

PHENOLOGY. Apparently flowers during the summer rainy season.

NOTES. The Bolivian population of this species is disjunct from the main population in southern Brazil. The original three specimens all seem correctly named but it would be reassuring to see new material. A fourth collection, cited by O'Donell (1959a: 61) from Cuesta de Guayabillas (Herzog 1662) has not been seen and this locality is uncertain, Herzog not having collected in Tarija Department, where there is a well-known Guayabillas.

Ipomoea indivisa is very close to I. coccinea and I. cholulensis Kunth, both of which also have unlobed leaves and deflexed fruiting pedicels. It is distinguished from both with difficulty by the crests on its seeds which have longer hairs different from the short tomentose hairs covering most of the seed. I. cholulensis differs additionally in the narrower, usually pubescent leaves. Preliminary molecular studies tend to support I. coccinea as a distinct species but do not confirm that I. indivisa is distinct from I. cholulensis.

98. Ipomoea dumetorum Willd. ex Roem. E Schult. (Roemer \& Schultes 1819: 789). Type: sin loc, probably Colombia or Ecuador, Humboldt $\mathcal{E}^{\circ}$ Bonpland (holotype B).

Twining annual herb, stems glabrous, sometimes muricate. Leaves petiolate, mostly $4-10 \times 3-7 \mathrm{~cm}$, ovate-deltoid (rarely 3-lobed), hastate to broadly cordate, auricles rounded or acute, apex acute and finely mucronate, margin entire or with a large marginal tooth, both surfaces usually glabrous but sometimes abaxially pubescent on veins near base; petioles $2.5-4(-8) \mathrm{cm}$. Inflorescence of pedunculate axillary cymes; peduncles $2-8 \mathrm{~cm}$, sometimes paired, glabrous or hirsute at base; bracteoles $2-3 \mathrm{~mm}$, narrowly linear-lanceolate, acuminate, \pm persistent; secondary peduncles short, $0.5-1 \mathrm{~cm}$; pedicels mostly $1-1.5 \mathrm{~cm}$, often recurved in bud; sepals slightly unequal, the inner slightly shorter than the outer, $5-6 \mathrm{~mm}$, broadly ovate to elliptic, obtuse, mucronulate, pale green with prominent dark spots and pale margins, outer sepals sometimes muricate; corolla $2-2.8 \mathrm{~cm}$, broadly funnel-shaped, glabrous, tube pale pink or white, limb pink (sometimes reported to be bluish), c. $2 \mathrm{~cm}$ diam. Capsule glabrous, ovoid, rostrate, the persistent style c. 2 mm long; seeds $5-6 \times 2-2.5 \mathrm{~cm}$, black, minutely tomentellous. Fig. 33E.

DISTRIBUTION \& HABITAT. This is a common species extending from Chile and Argentina north along the Andes through Central America to reach the southern United States. In Bolivia a very common species of disturbed, bushy places on the eastern Andean slopes usually between 2000 and $3000 \mathrm{~m}$, but exceptionally as low as $1600 \mathrm{~m}$ or as high as $3400 \mathrm{~m}$. Map 21.

SELECTED SPECIMENS OF 65 EXAMINED. BOLIVIA. Chuquisaca: Prov. Azurduy, Com. Trigo Loma, Camino Sopachuy-Tarvita, $19^{\circ} 42^{\prime} 41^{\prime \prime S} \quad 64^{\circ} 28^{\prime} 37^{\prime \prime} \mathrm{W}$, 2019 m, 27 April 2008, A. Lliully et al. 1160 (MO, OXF). Prov. Boeto, Nuevo Mundo, 1858'6"S 6418'12"W, 2181 m, 12 May 2004, J. Gutiérrez et al. 603 (ARIZ, HSB, LPB, MO). Prov. Tomina, 21 km from Padilla towards Monteagudo, $2370 \mathrm{~m}, 8$ March 1981, S. G. Beck 6301 (LPB). Prov. Zudañez, ANMI El Palmar, along trail from Thuruthuru towards El Palmar climbing above crossing of Río Missiones, 1841'56"S 6453'32"W, 2550 m, 31 March 2007, J. R. I. Wood et al. 23298 (K, LPB). Cochabamba: Prov. Arce, Cotani, 2450 m, Nov. 1911, O. Buchtien 4678 (US). 
Prov. Ayopaya, Río Tambillo, Est. Pajchanti, 3045 m, 26 April 1989, R. Baar 362 (LPB). Prov. Campero, c. $22 \mathrm{~km}$ del pueblo de Pasorapa, sobre el camino a Buena Vista, 18²4'13"S 6435'15"W, 2511 m, 24 March 2003, J. R. I. Wood et al. 19450 (BOLV, HSB, K, LPB, USZ). Prov. Capinota, Apillapampa, 17³1'03"S 6608'52"W, 3120 m, 9 April 2003 E. Thomas 371 (BOLV, LPB). Prov. Carrasco, between Pojo and Epizana, 3100 m, 19 Feb. 1995, J. R. I. Wood 9460 (K, LPB). Prov. Cercado, Cerveceria Colon, 2700 m, 14 March 1939, E. K. Balls 6214 (BM, BOLV, K, US). Prov. Chapare, Incacorial, 3350 m, 8 March 1929, J. Steinbach 9546 (GH, US). Prov. Punata, Com. Leon Rancho, 2700 m, 22 Feb. 1991, R. Guillén 410 (BOLV). La Paz: Prov. Inquisivi, Cajuata, Com. Parpata, $16^{\circ} 46^{\prime} \mathrm{S}$ 67¹6'20"W, 2424 m, 10 Oct. 2008, Maldonado et al. 3839 (LPB). Prov. Larecaja, Sorata, 26 May 1991, R. Fortunato 1875 (LIL). Prov. Murillo, Valle de Zongo, 2000 m, 14 June 1980, S. G. Beck 3668 (LPB, MO). Prov. Nor Yungas, Pitiguaya, Unduavi Valley, 1750 m, May 1926, G. Tate 739 (NY). Prov. Saavedra, Charazani near aguas termales, $15^{\circ} 10^{\prime} 50^{\prime \prime S}$ 68 54'03"W, 2535 m, 17 April 2005, A. Fuentes et al. 6840 (ARIZ, LPB, MO). Prov. Sud Yungas, Lirupaya near Yanacachi, 20 Nov. 1906, O. Buchtien 312 (US). Prov. Tamayo, PN Madidi, Patiapo, 14 29'05"S 68²'55"W, 1750 m, 10 July 2002, A. Araujo-M. 232 (LPB, MO). Santa Cruz: Prov. Caballero, Astillero, $31 \mathrm{~km}$ from Comarapa towards Cochabamba, 1751'05"S 6441'04"W, 19 April 2003, R. M. Ledezma $\mathcal{E}^{\circ}$ Munoz (MO, USZ). Prov. Vallegrande, $2 \mathrm{~km}$ NW of Pucarillo, 1848'34"S 6353'57"W, 1789 m, 23 May 2010, G. A. Parada E V. Rojas 2610 (MO, OXF, USZ). Tarija: Prov. Arce, Cerro Pabellón,

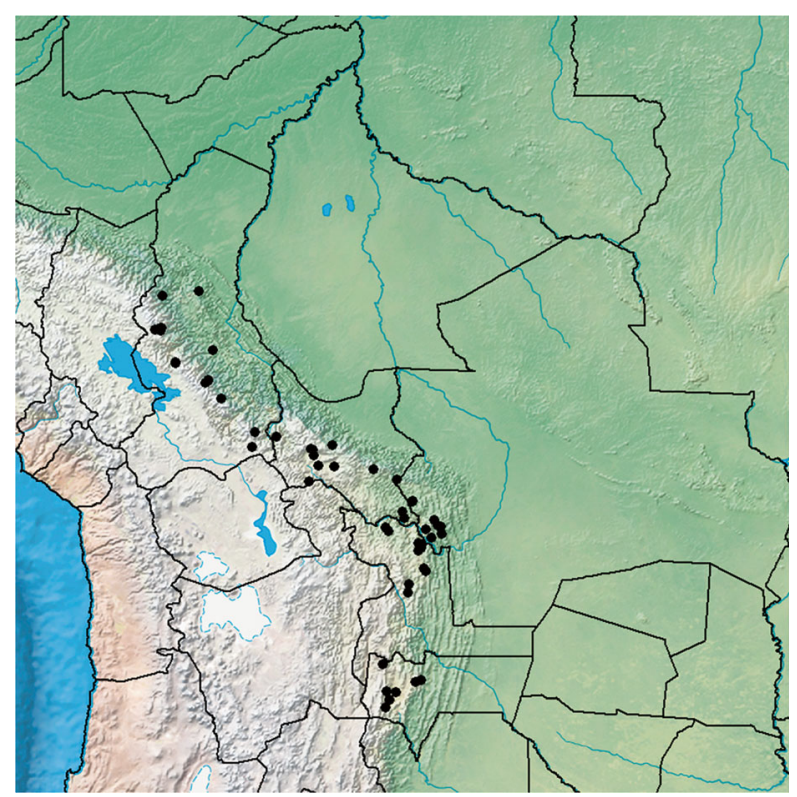

Map 21. Distribution of Ipomoea dumetorum (@), probably the commonest Andean species.
Com. Cañas, 21 $54^{\prime} \mathrm{S} 64^{\circ} 54^{\prime} \mathrm{W}, 2600 \mathrm{~m}, 15$ March 1998, S. G. Beck et al. 26076 (ARIZ, LPB). Prov. Avilez, Aliso-Antigal, 21 $46^{\prime} \mathrm{S} 64^{\circ} 50^{\prime} \mathrm{W}, 2100 \mathrm{~m}$,

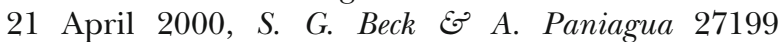
(LPB). Prov. Cercado, Alto España, 2400 m, 9 April 1988, R. Ehrich 516 (ARIZ, LPB). Prov. O'Connor, $1 \mathrm{~km}$ below Narvaez, 21 $25^{\prime} \mathrm{S} 64^{\circ} 16^{\prime} \mathrm{W}, 1700 \mathrm{~m}, 1$ 2 May 1983, J. Solomon 10389 (LPB, MO).

CONSERVATION STATUS. Least concern (LC).

PHENOLOGY. It is nearly always found in flower from February to May but it occasionally flowers in other months particularly in more humid areas.

NOTES. Readily identified in the field by its small pink (reported as pale blue in other countries) flowers and pale green sepals with distinct dark spots. It is sometimes confused with Ipomoea aristolochiifolia but usually grows at a higher altitude and the peduncle never passes through the sinus of the leaf base.

99. Ipomoea jujuyensis O'Donell (1948: 174). Type: Argentina, Jujuy, Lagunas de Yala, O'Donell 4835 (holotype LIL 182934!).

Twining perennial to $6 \mathrm{~m}$ from a tuberous rootstock, stems pubescent to subhispid. Leaves petiolate, $5-15 \times 3.5-9 \mathrm{~cm}$, ovate, shortly acuminate, cordate with rounded auricles, thinly adpressed pubescent; petioles $2-10 \mathrm{~cm}$, pubescent. Inflorescence of pedunculate axillary cymes with up to five flowers; peduncle $5-15 \mathrm{~cm}$, pubescent, stout; bracteoles 2 $-3 \mathrm{~mm}$ long, broadly lanceolate, caducous; pedicels $1-2.5$ $\mathrm{cm}$, thickened upwards, stout, pubescent, often deflexed at maturity; sepals slightly unequal, rounded and emarginate, usually mucronulate, the margins scarious, outer 6 $-8 \times 5-6 \mathrm{~mm}$, elliptic, obtuse, thinly pubescent, inner $7-$ $8 \times 8-9 \mathrm{~mm}$, suborbicular, glabrous; corolla $6.5-9 \mathrm{~cm}$, funnel-shaped from a short basal tube, violet, glabrous, limb 4.5 - $6 \mathrm{~cm}$ diam., undulate. Capsule ovoid, rostrate, glabrous, seeds tomentellous.

DISTRIBUTION \& HABITAT. Scattered from Ecuador to northern Argentina, this is a rare but possibly overlooked species in Bolivia growing at low altitudes in the Andes of La Paz.

SPECIMENS EXAMINED. BOlIVIA. La Paz: Prov. Sud Yungas, Puerto Rico, camino Asunta-Chulumani, 1555'15"S $67^{\circ} 13 ' 55^{\prime \prime W}, 630$ m, 22 Sept. 2007, M. Mendoza et al. 2622 (K, USZ).

CONSERVATION STATUS. Data deficient (DD). PHENOLOGY. Collected in flower in September. NOTES. Molecular studies indicate this species is related to Ipomoea dumetorum, with which it shares a strongly rostrate capsule, scarious-margined sepals and minutely tomentellous seeds. It is easily distinguished, however, by the perennial habit, larger corolla and absence of dark spots on the sepals. It is most likely to be confused with I. tarijensis but can be distinguished by the 
denser indumentum, longer stamens, deflexed fruiting pedicels and other characters provided under I. tarijensis.

100. Ipomoea plummerae A. Gray (1886: 434). Type: United States, Arizona, Lemmon 2839 (holotype GH!)

Ipomoea minuta R. E. Fr. (Fries 1905: 113). Type:

Argentina, Jujuy, Santa Catalina, Kurtz 11437

(lectotype S, designated by McDonald (1997: 111).

Completely glabrous perennial herb with subterranean bulb-like root tuber; stems usually several, branched near base, decumbent or ascending, up to $30 \mathrm{~cm}$ long but often very short. Leaves petiolate, small, digitately divided into $5-7$ segments, segments $3-30 \times 1-3 \mathrm{~mm}$, linear to linear-oblanceolate, obtuse and mucronate or (less commonly) simple, rhomboidal, basally cuneate but apically acute or 3-fid with acute lobes; petioles 3 $15 \mathrm{~mm}$. Flowers solitary, axillary, peduncles $5-12(-40)$ $\mathrm{mm}$; bracteoles 1 - $2 \mathrm{~mm}$, filiform; pedicels $1-4 \mathrm{~mm}$; sepals slightly unequal, outer 5.5. - $7 \mathrm{~mm}$, oblong, acute to obtuse, muricate, inner similar but $7-9 \mathrm{~mm}$ and with broad scarious margins and green, central, sometimes muricate midrib; corolla $2-3 \mathrm{~cm}$ long, glabrous, funnelshaped; tube dirty white, limb dark pink, c. 2 cm diam., unlobed. Capsule 6 - 7 mm long, subglobose, glabrous, the slender style persistent, 6-seeded; seeds 3-4 mm, dark brown, minutely tomentellous. Fig. 33C.

NOTE. Ipomoea plummerae is exceptionally variable in its leaf form and the following is quite frequently found growing with the type form and occasionally away from it. Intermediates are rare, if they occur at all. As this very distinctive form occurs apparently randomly with the type form it seems best to recognise it as a forma, rather than a variety. It does not have any habitat preference and does not seem to occur in distinct isolated populations.

Ipomoea plummerae forma adiantifolia Ooststr. (Ooststroom 1933: 210). Type: Peru, Arequipa, A. Weberbauer 1561 (holotype B, n.v.)

Ipomoea minuta forma adiantifolia (Ooststr.) O'Donell (1959b: 193).

Ipomoea cuneifolia A. Gray (1886: 434), non I. cuneifolia Meisn. (Meisner 1869). Type: United States, Arizona, J. G. Lemmon 2837 (holotype GH!; isotypes CAS, F, MO, NY!, US!).

Ipomoea plummerae var. cuneifolia (A. Gray) J. F. Macbr. (Macbride 1931: 4).

Ipomoea plummerae forma rhombifolia Ooststr. (Ooststroom 1936: 221). Type: Bolivia, Potosi, Lagunillas, M. Cardenas 430 (lectotype US!, designated by McDonald (1995: 115).

Distinguished by rhomboidal leaves, $0.5-2 \times 0.3-$ $1.5 \mathrm{~cm}$, basally cuneate but apically acute, entire, crenate or deeply 3 - 5-toothed or lobed. Usually growing with the type form but less common, only 14 of a total of 64 records of Ipomoea plummerae relate to this form. Fig. 33D.

DISTRIBUTION \& HABITAT. A species with a disjunct distribution being found in Peru, Bolivia and Argentina in South America and the United States and Mexico in North America. In Bolivia a characteristic species of open stony hillsides with subpuno vegetation between 2400 and $4000 \mathrm{~m}$, the lower altitudes being recorded from the south of Bolivia in Tarija and Chuquisaca Departments. It is usually in small quantities, often only a single plant being found. The citations below reveal a few interesting facts, the species being noticeably more frequent in the centre of Bolivia than in the northern La Paz Department. It is much the most frequent species of Ipomoea in Potosi Department. Map 22.

SELECTED SPECIMENS OF 66 EXAMINED. (forma plummerae unless indicated otherwise). BOLIVIA. Chuquisaca: Prov. Oropeza, Siete Cascadas near Sucre, $2880 \mathrm{~m}$, 15 Feb. 2004, H. Huaylla 989 [both forms] (MO). Prov. Nor Cinti, Malliri, San Lucas, 20¹6'47"S 6501'17"W, 3167 m, 16 Dec. 2006, J. Gutiérrez 245 (HSB). Prov. Sud Cinti, 3 horas NW Com. Orocote, 2047'S 64²1'W, 1650 m, 29 April 2005, R. Lozano et al. (MO, US). Prov. Tomina, $10 \mathrm{~km}$ from El Villar towards Alcala, 19 34 "S 64¹9'56"W, 2552 m, 8 Jan. 2004, A. Carretero et al. 1153 (ARIZ, HSB, MO). Prov. Yamparaez, along road from Tarabuco to Zudañez c. $2 \mathrm{~km}$ above gorge of Lamboyo, 2600 m, 17 March 2002, J. R. I. Wood 17843 [both forms] (K, LPB). Prov. Zudañez, AMNI El Palmar, ascending Río Molle Waypu, c. 4 km from El Rodeo, 1843'07"S 6452'18"W, 2619 m, 3 Feb. 2007, J. R. I. Wood et al. 22625 (HSB, K, LPB). Cochabamba: Prov. Arani, c. $10 \mathrm{~km} \mathrm{E}$ of Arani along road towards Mizque, 3400 m, 8 March 2002, J. R. I. Wood 17749 (K, LPB). Prov. Arque, Est. Chapi-Chapi, 17²9'S 66 $24^{\prime} \mathrm{W}$, 2 Jan. 1992, P. Ibisch $\mathcal{E}^{2}$ Rojas 745 (BOLV, LPB). Prov. Ayopaya, Río Tambillo, Est. Linco, 3030 m, 28 March 1989, R. Baar 95 (LPB). Prov. Campero, c. $22 \mathrm{~km}$ del pueblo de Pasorapa, sobre el camino a


March 2003, J. R. I. Wood et al. 19454 [forma adiantifolia] (K, LPB). Prov. Carrasco, between López Mendoza and Montepuncu, 3100 m, 16 Dec. 1994, J. R. I. Wood 8959 [both forms] (K, LPB). Prov. Cercado, Cerro San Pedro, 2550 m, Feb. 1942, M. Cardenas 2261 (GH, LIL). Prov. Mizque, entre Rakaypampa and Lagunas, 3080 m, 21 Feb. 1994, C. Antezana 784 (BOLV). Prov. Quillacollo, Com. Cruzani, $17^{\circ} 18^{\prime} 10^{\prime \prime S} 66^{\circ} 12^{\prime} 59^{\prime \prime W}, 3200 \mathrm{~m}, 14$ Feb. 2006, M. Zarate et al. 2180 [both forms] (BOLV, LPB, MO). La Paz: Prov. Ingavi, Huacullani, 3950 m, 37 Feb. 1979, S. G. Beck 323 [forma adiantifolia] (FTG, LPB). Prov. Larecaja, Sorata, Munaypata, 2650 m, Feb. 1860, 
G. Mandon 1490 (BM, K, NY, P). Prov. Murillo, cerca de Aranjuez, 16 $333^{\prime} \mathrm{S} 68^{\circ} 05^{\prime} \mathrm{W}, 3300$ m, 11 March 2001, S. G. Beck 24966 (LPB). Potosi: Prov. Bustillos, 41 km de Uncia hacia Pocoata, 3300 m, 6 March 1981, S. G. Beck 6172 [forma adiantifolia] (LPB). Prov. Charcas, Torotoro, desvio del camino principal rumbo al Vergel, $18^{\circ} 07^{\prime} 11^{\prime \prime S}$ 6546'10"W, 2649 m, 26 Feb. 2003, J. R. I. Wood et al. 19214 (BOLV, K, LPB). Prov. Chayanta, Pocoata, 3385 m, Sept. 1996, Zamora 169 (LPB). Prov. Frías, Cercado, between La Palca and Cayara, 3500 m, 27 Dec. 1994, J. R. I. Wood 9021 (K, LPB). Prov. Linares, Alkatuyo, Cerro Tuyro, $19^{\circ} 53$ 'S 653' 3560 m, 16 March 1993, Marino 31 (LPB). Prov. Saavedra, Com. Despensa, 19²0'S $65^{\circ} 20^{\prime W}$, Romero 100 (LPB). Prov. Sud Chichas, SW Com. Espicaya, 21 ${ }^{\circ} 35^{\prime} 55^{\prime \prime S}$ 65 51'42"W, 3787 m, 29 Feb. 2012, F. Zenteno E Moya 11610 (LPB). Santa Cruz: Prov. Vallegrande, camino hacia la "Ruta del Che", 18 $36^{\prime} 21$ "S 6407'45"W, 2843 m, 11 March 2011, L. Arroyo et al. 5466 (USZ). Tarija: Prov. Arce, Cerro Pabellón, arriba de Cañas, 21 52 'S 645' W, 2700 m, 15 March 1998, S. G. Beck et al. 26106 (LPB). Prov. Cercado, Tucumilla, 2800 m, 30 Dec. 1903, K. Fiebrig 2446 (BM, GH, K, P). Prov. Mendez, Rincón de la Victoria, 14 Feb. 1960, T. Meyer et al. s.n. (LIL).

CONSERVATION STATUS. Least concern (LC).

PHENOLOGY. Flowers mainly from mid December to mid April, appearing after the onset of significant summer rain.

NOTES. Amongst Bolivian species unmistakeable because of its habitat, roostock and low, slender habit but sometimes misidentified as Ipomoea capillacea (Kunth) G. Don, a species from Colombia and Venezuela north to the United States.

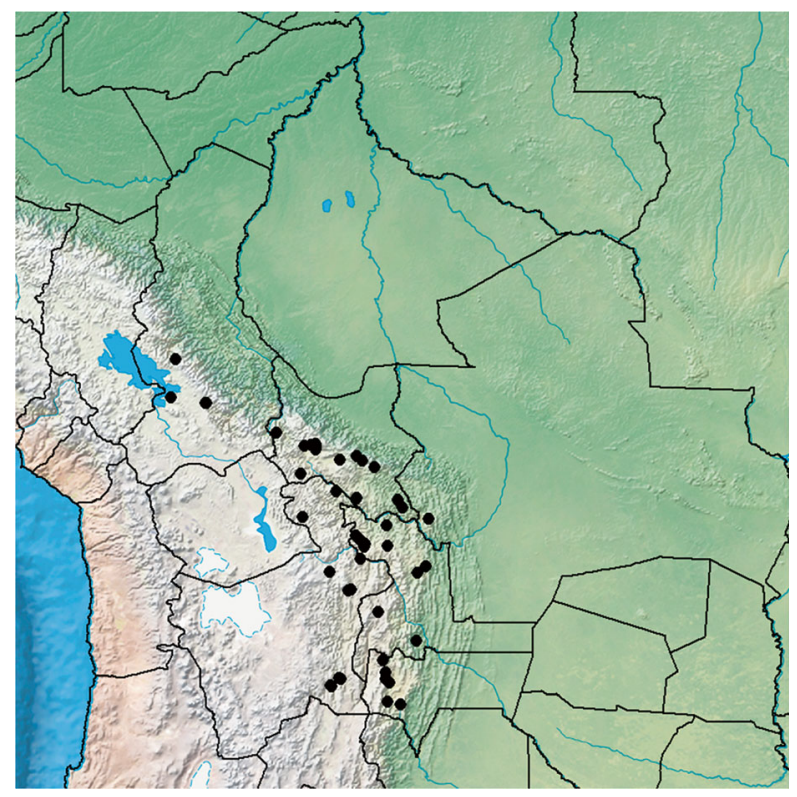

Map 22. Distribution of Ipomoea plummerae (-), which reaches $4000 \mathrm{~m}$ in the central Andes, noticeably less common in the La Paz area.
101. Ipomoea wrightii A. Gray (1878: 213). Type: United States, Texas, Wright s.n. (holotype GH!).

Ipomoea gracilipes Hassler (1911: 158). Type: Paraguay, zwischen Río Apa und Río Aquidaban, K. Fiebrig 5744 (holotype G; isotype K000612826!).

Ipomoea pulchella auct., non Roth (1821), which is I. cairica (L.) Sweet (Verdcourt 1961).

Twining annual herb, plant completely glabrous in all parts. Leaves petiolate, divided into $5-7$ separate sessile leaflets, leaflets $3-7 \times 0.3-1 \mathrm{~cm}$, narrowly lanceolate, acuminate at both ends; petioles $2.5-5.5 \mathrm{~cm}$. Flowers solitary (rarely paired), axillary, pedunculate; peduncles slender, flexuose and sometimes coiled, $3-6 \mathrm{~cm}$ long; bracteoles minute, $\mathrm{c}$. $1 \mathrm{~mm}$, scale-like, caducous; pedicels $5-8 \mathrm{~mm}$, stouter than peduncles; sepals subequal, $5-7 \mathrm{~mm}$, scariousmargined, outer $4-5 \times 2.5-3 \mathrm{~mm}$, ovate, obtuse, abaxially slightly muricate, inner $5-6 \times 3 \mathrm{~mm}$, broadly oblong, rounded; corolla $1.7-2.2 \mathrm{~cm}$ long, funnelshaped, pink, glabrous; limb c. $1 \mathrm{~cm}$ diam. Capsule $10 \times 7$ $\mathrm{mm}$, ovoid, glabrous; seeds $5 \times 2.5 \mathrm{~mm}$, tomentose.

DISTRIBUTION \& HABITAT. Widely distributed throughout the neotropics but never very common. In Bolivia a rare plant of disturbed seasonally moist areas around the northern fringes of the Chaco.

SPeCimens examined. BoliviA. Santa Cruz: Prov. Chiquitos, entre Las Tunas y El Tinto, camino hacia San José de Chiquitos, 17³9'04"S 61³5'48'W, 269 m, 4 March 2011, J. R.I. Wood Eं D. Soto 27105 (K, LPB, USZ). Prov. Cordillera, PN Kaa-Iya, Hito 27 de Noviembre, $20^{\circ} 05^{\prime} 21^{\prime \prime} \mathrm{S} 61^{\circ} 55^{\prime} 21^{\prime \prime W}, 318$ m, 14 July 1998 (fr.), A. Fuentes $\mathcal{E}^{\circ}$ G. Navarro 2524 (LPB, USZ). Prov. Germán Busch, Southern edge of Laguna Cáceres, Puerto Suárez, 1858'S, 5747'30'W, 80 m, 5 May 1990, R. Frey et al. 507 (K, MO). CONSERVATION STATUS. Although rare in Bolivia this species is widely distributed throughout the American continent. Using Geocat it would be classified as Least Concern (LC) based on its extent of occurrence but the true classification has to be Data Deficient (DD). We do not know whether the populations are permanent or whether the plant has been overlooked. Its distribution in Bolivia and Paraguay suggests it may be restricted to the Chaco region and the lack of records suggests it is uncommon.

PHENOLOGY. Like other annual species it flowers at the end of the rainy season from February to May.

NOTES. Distinguished from other species with 5foliolate leaves by the annual habit, small flowers and slender flexuose peduncles.

102. Ipomoea subrevoluta Choisy (1845: 386). Type: Guyana, C. S. Parker s.n. in Herb. Lindley (holotype CGE 14419!; isotypes K!).

Twining perennial herb, completely glabrous in all parts. Leaves petiolate, divided into $5(-7)$ separate sessile 
leaflets, leaflets $2.5-6 \times 0.1-0.4(-0.7) \mathrm{cm}$, linear to narrowly oblong, apiculate, acuminate at base; petioles $0.5-5 \mathrm{~cm}$. Inflorescence of 1 (-3)-flowered, axillary, pedunculate cymes; peduncles slender, $0.8-1.8 \mathrm{~cm}$, often flexuose; bracteoles $1.5 \mathrm{~mm}$, deltoid, caducous; pedicels $1-1.5 \mathrm{~cm}$, stouter than peduncles; sepals subequal, $5-6 \times 2-3 \mathrm{~mm}$, ovate, shortly apiculate, pale green; corolla $4-6 \mathrm{~cm}$, funnel-shaped, pink, glabrous, limb c. 4 cm diam., unlobed. Capsule $12-$ $14 \mathrm{~cm}$ long, ovoid, glabrous; seeds $5-6 \mathrm{~mm}$, dark brown, nearly glabrous. Fig. 19J - L.

DISTRIBUTION \& HABITAT. Widely distributed in wetlands in tropical South America from Colombia and the Guyanas south to northern Argentina but uncommon and often misidentified; also in Cuba. In Bolivia it is characteristic of small streams with moving water in open areas below $500 \mathrm{~m}$, principally in the cerrado biome. It is very scattered in occurrence, usually in small populations and has been mostly collected along the Río Paraguá between Florida and El Refugio. It seems likely that it is more common than shown in Map 23, particularly as suitable habitas are common in the Beni and around the Pantanal.

SELECTED SPECIMENS OF 22 EXAMINED. BOLIVIA. Beni: Prov. Ballivian, $40 \mathrm{~km}$ N of Santa Rosa hacia Riberalta, 22 Oct. 1991, S. G. Beck 20707 (LPB). Prov. Cercado, Laguna Suárez, $14^{\circ} 52^{\prime} \mathrm{S} 64^{\circ} 52^{\prime} \mathrm{W}, 160$ m, 19 June 1996 , N. Ritter $\mathcal{E}$ M. Ritter 3367 (BOLV, LPB). Prov. Marban, Laguna Bolivia, 200 m, 5 June 1992, López et al. 83 (LPB). Prov. Moxos, TIPNIS (PN Isiboro Sécure), Río Isiboro, $65^{\circ} 09^{\prime} 53^{\prime \prime} \mathrm{S} 15^{\circ} 32^{\prime} 16^{\prime \prime} \mathrm{W}, 180 \mathrm{~m}, 9$ Oct. 1995 , E. Gutiérrez E G G. Navarro 1641 (USZ). Pando: Prov. Manuripi, Conquista, 27 March 195, E. de la Sota 993

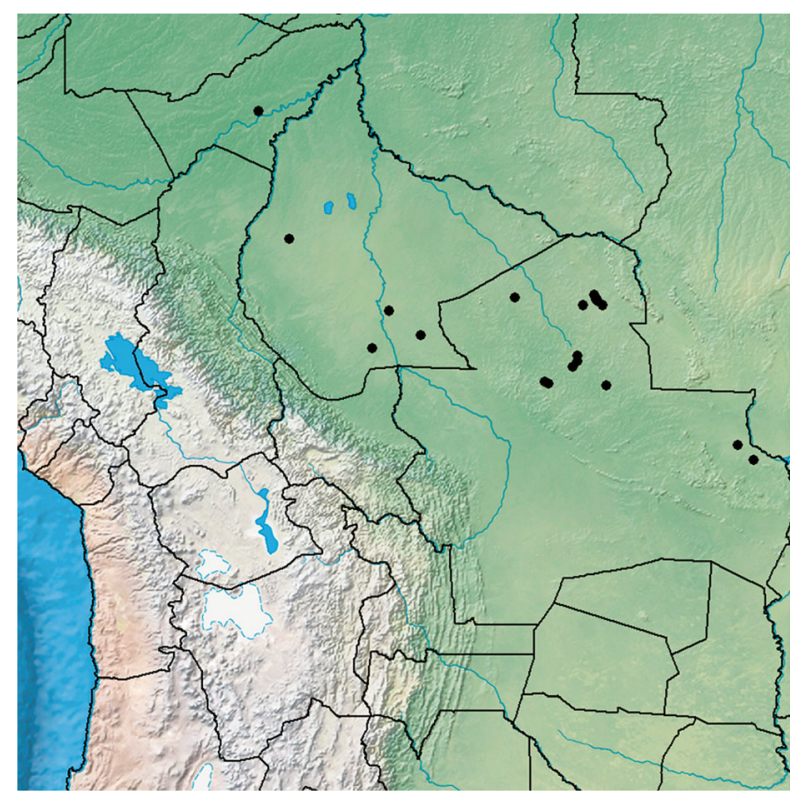

Map 23. Distribution of Ipomoea subrevoluta (-), a low altitude species of streamsides.
(LIL). Santa Cruz: Prov. Nuflo de Chávez, Est. Viera, $2 \mathrm{~km} \mathrm{~S}$ of Concepción, $16^{\circ} 08^{\prime} \mathrm{S} 62^{\circ} 05^{\prime} \mathrm{W}, 480 \mathrm{~m}, 23$ March 1987, T. J. Killeen 2403 (F, FTG, LPB, NY, USZ); Perseverancia, $14^{\circ} 38^{\prime} \mathrm{S} 62^{\circ} 37^{\prime} \mathrm{W}, 200 \mathrm{~m}, 12$ June 1990 , I. G. Vargas 589 (USZ). Prov. Ángel Sandoval, ANMI San Matías, Est. Vista Hermosa, 17 $31^{\prime} 40^{\prime \prime} \mathrm{S} 58^{\circ} 21^{\prime} 06^{\prime \prime} \mathrm{W}, 73 \mathrm{~m}$, 19 Sept. 1999, A. M. Carrión E E. Rivera 790 (USZ); San Fernando, 17 $16^{\circ} 04^{\prime \prime S} 58^{\circ} 38^{\prime} 31^{\prime \prime W}, 161$ m, 8 May 1997, J. Balcazar et al. 1233 (USZ). Prov. Velasco, El Refugio, $14^{\circ} 46^{\prime} 17^{\prime \prime S} 61^{\circ} 02^{\prime} 38^{\prime \prime W}, 150 \mathrm{~m}, 28$ May 1994, R. Guillén E' S. Coria 1585 (ARIZ, MO, USZ); $15 \mathrm{~km}$ N of Santa Rosa de la Roca, $15^{\circ} 46^{\prime} 05^{\prime \prime S} 61^{\circ} 29^{\prime} 24^{\prime \prime W}, 344$ m, 13 April 2013, J. R. I. Wood et al. 27813 (K, LPB, USZ).

CONSERVATION STATUS. Least Concern (LC) but vulnerable to habitat change, particularly drainage of wetlands. PHENOLOGY. Flowers mostly towards the end of the rainy season from March to July.

NOTES. Usually easily recognised by the very short sepals combined with the 5-foliolate leaves and relatively large glabrous flower.

\section{Acknowledgements}

We are very grateful to the curators of the following herbaria for providing access to their collections: in Europe, BM, E, K, MA, OXF, P; in North America: ARIZ, FTG (at Tucson), GH, MICH, MO, NY, US; in South America CIP (Lima), CPAP, CTES, HUEFS, LIL, MBM, R, $\mathrm{RB}, \mathrm{SP}$ and in Bolivia BOLV, HSB, LPB, USZ. USZ has provided us with an especially valuable loan. We are also grateful to $\mathrm{G}, \mathrm{GOET}, \mathrm{M}$ and $\mathrm{W}$ for sending images of types which have helped elucidate problems of typification. On-line images, particularly those available from BR, $\mathrm{C}, \mathrm{MO}, \mathrm{NY}$ and $\mathrm{P}$ have also been very useful. We are grateful to various colleagues who provided us with photographs: Alfredo Fuentes, Hibert Huaylla, Alexander Parada, Daniel Soto, Louise Emmons, Julia Gutiérrez, Norha Paucar and Nelly de la Barra as well as those who participated in the two Darwin projects 162/11/010 and 16-004. Thanks are due to staff at Kew and Oxford, especially Serena Marner, who has processed loans, to John Baker for help with photographs and to Rosemary Wise who prepared the line drawings. We have benefitted in different ways from comments and discussions with various people, including Nick Turland for advice on typification issues, and the late Dan Austin, Rosangela Simão Bianchini and George Staples who all work on Convolvulaceae. We acknowledge the financial support of the Leverhulme Foundation for funding the main project and the Darwin Initiative who funded much of the original fieldwork. We also received support from an NERC IAA award for the illustrations and we are grateful to Sam Gallagher of MPLS, Oxford for helping process this. John Wood acknowledges support for his visits to the herbaria of the Royal Botanical Garden in Madrid and the Natural History Museum in Paris from the SYNTHESYS Project http://www.synthesys.info/ 
which is financed by the European Community Research Infrastructure Action under the FP7 "Capacities" Program. Finally, he would like to acknowledge the help and companionship of many Bolivian botanists whose names appear in the text.

Open Access. This article is distributed under the terms of the Creative Commons Attribution 4.0 International License (http://creativecommons.org/ licenses/by/4.0/), which permits unrestricted use, distribution, and reproduction in any medium, provided you give appropriate credit to the original author(s) and the source, provide a link to the Creative Commons license, and indicate if changes were made.

\section{References}

Ascherson, P. F. A. \& Schweinfurth, G. A. (1867). Beitrag zur Flora Aethiopiens. Georg Reimer, Berlin.

Austin, D. F. (1975). Convolvulaceae. In: R. E. Woodson \& R. W. Schery, Flora of Panama. Ann. Missouri Bot. Gard. 62: 157 - 224.

(1977). Ipomoea carnea Jacq. vs. Ipomoea fistulosa

Mart. ex Choisy. Taxon 26 (2/3): 235 - 238.

(1978). The Ipomoea batatas complex - 1 .

Taxonomy. Bull. Torrey Bot. Club. 105(2): 114 - 129. (1991). Ipomoea sawyeri (Convolvulaceae), a new species from Peru. Brittonia 43 (2): 93 - 95.

\& Huáman, Z. (1996). A synopsis of Ipomoea

(Convolvulaceae) in the Americas. Taxon 45 (1): 3 38.

McDonald, J. A. \& Murguía-Sánchez, G. (2012). Convolvulaceae. In: Flora Mesoamericana 4 (2): 318 352. Universidad Nacional Autónoma de México, Missouri Botanical Garden, St Louis and The Natural History Museum, London.

\& Staples, G. W. (1983). Additions and changes in the Neotropical Convolvulaceae - Notes on Merremia, Operculina and Turbina. J. Arnold Arbor. 64: 483 - 489.

\& _ (1991). A revision of the Neotropical species of Turbina Raf. (Convolvulaceae). Bull. Torrey Bot. Club 118 (3): 265 - 280.

Bentham, G. (1844). The Botany of the Voyage of H.M.S. Sulphur. Smith, Elder \& Co, London.

Biju, S. D. (2002) [publ. 2003]. Lectotypification of two Linnean specific names in Convolvulaceae. Taxon 51: $755-756$.

Bosser, J. \& Heine, H. (2000). Convolvulacées. Fl. Mascareignes 127: 1 - 63. Diffusion IRD, Bondy, Mauritius Sugar Industry Research Institute, Maurice \& Royal Botanic Gardens, Kew.

Brown, N. E. (1894). The Botany of the Pilcomayo Expedition; being a list of plants collected during the Argentine expedition of 1890-91 to the Rio Pilcomayo. Trans. Eं Proc. Bot. Soc. Edinburgh 20: 44 - 78.

Brown, R. (1810). Prodromus Florae Novae Hollandiae et Insula van Diemen. Johnson \& Co, London.

Burman, J. (1755). Index universalis in sex tomos et auctuarium herbarii amboinensis $\mathrm{Cl}$. Georgii Everhardi Rumphii, Amsterdam.

Cavanilles, A. J. (1795). Icones et descriptiones plantarum, Vol 3. 1 - 52. Typografia Regia, Madrid.

Cervantes, V. de (1824). In: P. de La Llave \& J. J. M. de Lexarza, Novorum Vegetabilium Descriptiones 1: 1 - 32. Martin Rivero, Mexico.

Chodat, R. \& Hassler, E. (eds) (1905). Plantae Hasslerianae. Bull. Herb. Boissier, Ser. 2, 5: 671 - 699.

Choisy J. D. (1834). Convolvulaceae Orientales. Mém. Soc. Phys. Genève 6: 383 - 502 (reprinted with pagination $381-120)$.

(1838). De Convolvulaceis Dissertatio Secundo.

Mém. Soc. Phys. Genève 8: 212 - 164 (reprinted with pagination $43-86)$.

(1845). Convolvulaceae. In: A. de Candolle (ed.), Prodromus Systematis Naturalis 9: 323 - 462. Fortin, Masson \& Co, Paris.

Dammer, U. (1897). Convolvulaceae. In: I. Urban, Plantae novae americanae imprimis Glaziovianae 1. Bot. Jahrb. Syst. 23, Beibl. 57: 36 - 42.

Dennstedt, A. W. (1810). Nomenclator botanicus. Part 1. Wilhelm Schoene, Eisenberg.

Deroin, T. (2001). Convolvulaceae. In: Flore de Madagascar et des Comores 171: 11 - 287. Muséum National d'Histoire Naturelle, Paris.

Desrousseaux, L. A. J. (1796). In: J. B. A. P. M. Lamarck, Encyclopédie méthodique: botanique Vol. 3. Paris.

Don, G. (1838). A general history of the dichlamydeous plants, Vol. 4. J. G. \& F. Rivington et al., London.

Donnell Smith, J. (1905). Undescribed plants from Guatemala and other Central American Republics. Bot. Gaz. 40: 1 - 12.

Ducke, A. (1959). Estudos botánicos no Ceará. Anais Acad. Brasil. Ci. 31: 211 - 308.

Elliot, S. (1817). A sketch of the botany of South-Carolina and Georgia, Vol. 1. J. R. Schenck, Charleston.

Fosberg, F. R. (1976). Ipomoea indica taxonomy; a tangle of morning glories. Bot. Not. 129(1): 35 - 38 .

Foster, R. C. (1958). A catalogue of the ferns and flowering plants of Bolivia. Contr. Gray Herb. 184: 1 - 223.

Fries, R. E. (1905). Zur Kenntnis der Alpinen Flora im nördlichen Argentinien. Nova Acta Regiae Soc. Sci. Upsal., Ser. 4 (1): 1 - 205

Gardner, G. (1842a). Ipomoea (Orthipomoea) nerifolia Gardn. Icon. Pl. t. 471. (1842b). Ipomoea (Strophipomoea) goyazensis Gardn. Icon. Pl. t. 479.

Gray, A. (1878). A synoptical Flora of North America, ed. 1, 2 (1). Ivison, Blakeman, Taylor \& Co., New York. 
(1886). A synoptical Flora of North America ed. 2, 2 (1). Ivison, Blakeman, Taylor \& Co., New York.

Grisebach, A. H. R. (1879). Symbolae al floram argentinam. Dietrich, Göttingen.

Hallier, H. (1897). Bausteine zu einer Monographie der Convolvulaceen, 6. Die Gattung Calonyction. Bull. Herb. Boissier 5: 1021 - 1052.

(1899a). Zur Convolvulaceenflora Amerikas. Jahrb. Hamburg Wiss. Anst. 16, app. 3: 19 - 56.

(1899b). Convolvulaceae. In: R. Chodat \& E. Hassler, Plantae Hasslerianae. Bull. Herb. Boissier 7, App. 1: $43-87$.

(1922). Convolvulaceae. In: T. Herzog, Die von Dr. T. Herzog auf seiner zweiten Reise durch Bolivien in den Jahren 1910 und 1911 gesammelten Pflanzen 6. Meded. Rijks-Herb. 46: 12 - 21.

Hassler, E. (1911). Ex Herbario Hassleriano: Novitates paraguariensis X11. Repert. Spec. Nov. Regni Veg. 9: $145-160$.

Hoehne, F. C. (1938). Cincoenta e uma novas espécies da flora do Brasil e outras descripções e ilustrações. Arq. Bot. Estado Sao Paulo, n.s. 1: 1 - 38 \& tab. 1 - 45.

Hooker, W. J. (1839). Ipomoea bonariensis. Buenos-Ayres Ipomoea. Bot. Mag. 65, t. 3665.

House, H. D. (1908). The North American species of the genus Ipomoea. Ann. New York Acad. Sci. 18(6): $181-263$.

IUCN (2012). Guidelines for application of IUCN Red List Criteria at Regional and National Levels. International Union for the Conservation of Nature, Gland.

Jacquin, N. J. (1760). Enumeratio Systematica Plantarum: 13. Theodorum Haak, Lugduni Batavorum. (1788). Collectanea, Vol. 2. Wappler, Vindobonae (Vienna).

(1790 [publ. 1791]). Collectanea, Vol. 4. Wappler, Vindabonae (Vienna).

(1798). Plantarum rariorum horti caesarei schoenbrunnensis Vol. 3: 1 - 80 Wappler. Vienna \& B. \& J. White, London.

Jorgensen, B. M., Nee, M. \& Beck, S. G. (eds) (2015). Catálogo de las Plantas Vasculares de Bolivia. 2 Vols. Missouri Botanical Garden Press, St Louis.

Ker-Gawler, J. B. (1818). Ipomoea setosa - Bristly Ipomoea. Bot. Reg. 4: t. 335

Krapovickas, A. (2009). Novedades en Convolvuláceas argentinas. Bonplandia 18(1): 57 - 64 .

Kunth, C. S. (1819). Nova Genera et Species Plantarum, Vol. 3. Librairie Grecque-Latine-Allemande, Paris.

Kuntze, O. (1898). Revisio Generum plantarum, Vol. 3. A. Felix, Leipzig.

Lagasca y Segura, M. (1816). Genera et species plantarum. Madrid.

Lamarck, J. de (1793). Tableau encyclopédique et méthodique, vol. 1, part 2 (2). Pancoucke, Paris.

Lindley, J. (1837). Pharbitis diversifolia Three-lobed Convolvulus Major. Bot. Reg. 23, t. 1988.
Linnaeus, C. (1753). Species plantarum, ed. 1. Salvius, Stockholm.

(1759). Systema Naturae, ed. 10. Salvius, Stockholm.

(1762). Species Plantarum, ed. 2. Salvius, Stockholm.

(1767). Mantissa plantarum [pars prima]. Salvius, Stockholm.

Macbride, J. F. (1931). Spermatophytes, mostly Peruvian - III. Publ. Field Mus. Nat. Hist. Bot., Ser. 11: 3 - 35.

Mamani, F., Pozo, P., Soto, D., Villarroel, D. \& Wood, J. R. I. (2010). Libro Rojo de las Plantas de los Cerrados dell Oriente Boliviano. Museo Noel Kempff Mercado, Santa Cruz.

McDonald, A. (1994). Convolvulaceae 2. Flora of Veracruz, fasc. 77. Instituto de Ecología, A. Xalapa, Veracruz \& University of California, Riverside.

(1995). Revision of Ipomoea section Leptocallis (Convolvulaceae). Harvard Pap. Bot. 6: 97 - 122.

McPherson, G. (1981). Studies in Ipomoea (Convolvulaceae) I. The Arborescens group. Ann. Missouri Bot. Gard. 68: $527-545$.

Meisner, C. F. (1869). Convolvulaceae. In: C. Martius, Flora Brasiliensis 7: 200 - 424. Fleischer, Leipzig.

Merrill, E. D. (1917). An interpretation of Rumphius's Herbarium Amboinense. Manila.

Moore, S. (1895). The Phanerogamic Botany of the Matto Grosso Expedition, 1891-92. Trans. Linn. Soc. London, Bot. 4: 265 - 516.

Morong, T. \& Britton, N. L. (1892). An enumeration of the plants collected by Dr. Thomas Morong in Paraguay. Ann. New York Acad. Sci. 7: $45-280$.

O'Donell, C. A. (1948). Convolvulaceas Argentinas y Paraguayas nuevas o críticas. Lilloa 14: 169 - 192. (1950a). Una nueva Convolvulacea Brasileña. Dusenia 1 (6): 375 - 378. 5: 1048. (1950b). Convolvulaceas Americanas Nuevas o Criticas 1. Lilloa 23: 421 - 456. (1950c). Convolvulaceas Americanas Nuevas o Criticas 2. Lilloa 23: 457 - 509. (1952). Convolvulaceas Americanas Nuevas o Criticas 3. Arq. Mus. Paranaense Curitiba 9: 207 - 244. (1953). Convolvulaceas Americanas Nuevas o Criticas 4. Lilloa 26: 353 - 400. (1959a). Las especies americanas de Ipomoea L. sect. Quamoclit (Moench.) Griseb. Lilloa 29: 19 - 86. (1959b). Convolvuláceas argentinas. Lilloa 29: $87-348$.

(1960). Notas sobre Convolvulaceas Americanas. Lilloa 30: 39 - 69.

Ooststroom, S. J. van (1933). Neue und kritische Convolvulaceae aus Peru. Meded. Bot. Mus. Herb. Rijks Univ. Urecht 7: Extrait du Recueil des Travaux botaniques neerlandais 30: $192-211$.

(1936). Beiträge zur Kenntnis der südamerikanischen Convolvulaceen. Meded. Bot. Mus. Herb. Rijks Univ. 
Utrecht 28: Extrait du Recueil des Travaux botaniques neerlandais 33: 211 - 222.

Peter, A. (1891). Convolvulaceae. In: H. G. A. Engler \& K. Prantl (eds), Die natürlichen Pflanzenfamilien IV (3a). Engleman, Leipzig.

Poiret, J. L. M. (1804). In: J. Lamarck, Encyclopédie méthodique, Vol. 6, part 1. Panckoucke \& Plomteux, Liège.

(1813, publ. 1814). In: J. Lamarck, Encyclopédie méthodique, Suppl. 3. Agasse, Paris.

Rafinesque, C. S. (1838). Flora telluriana, Vol 4. H. Probasco, Philadelphia.

Roemer, J. J. \& Schultes, J. A. (1819). Systema vegetabilium secundum, Vol. 4. J. G. Cotta, Stuttgart.

Roth, A. W. (1787). Botanische Abhandlungen und Beobachtungen. J. J. Winterschmidt, Nürnberg. (1797). Catalecta Botanica fasc. i. I. G. Mülleriano, Lipsiae.

(1821). Novae Plantarum Species. Sumptibus H. Vogleri, Halberstadii.

Ruiz, H. \& Pavon, J. A. (1799). Flora Peruviana, et Chilensis, Vol. 2. Typis Gabrielis de Sancha, Madrid.

Rusby, H. H. (1896). On the collections of Mr. Miguel Bang in Bolivia. - Part III. Mem. Torrey Bot. Club 6(1): $1-130$.

(1899). An enumeration of the Plants collected by Dr. H. H. Rusby in South America, 1885 - 1886. - XXVI. Bull. Torrey Bot. Club 26: 145 - 152.

Schumann, K. M. (1900). Neue Arten der Siphonogamen 1898. Just's Bot. Jahresber. 26: 323 - 396.

Silva Manso, A. L. P. (1836). Enumação das Substancias Brazileiras. Typographia Nacional, Rio de Janeiro.

Smith, L. B. \& Schubert, B. G. (1939). Plantae Mexicanae - 1. Contr. Gray Herb. 127: 20 - 33.

Stafleu, F. A. \& Cowan, R. S. (1981). Taxonomic Literature Vol. III: Lh - O. Bohn, Scheltem \& Holkema, Utrecht \& W. Junk, The Hague.

Staples, G. W. \& Jarvis, C. (2006). Typification of Linnaean Plant Names in Convolvulaceae. Taxon 55: 1019 - 1024.
Austin, D. F. \& Simão-Bianchini, R. (2012). Disposition of the names published by A. Peter in Convolvulaceae. Taxon 61(3): 671 - 679.

Stearn, W. (1974). The typification of Convolvulus corymbosus L. and the identity of Legendrea mollissima W. \& B. Cuad. Bot. Canaria 21: 5 - 12.

(1976). Turbina corymbosa. Bot. Mag 181: 59 - 65 t. 718.

Stellfeld, C. (1945). Antônio Luiz Patricio da Silva Manso. Tribuna Farm. 13: 83 - 87.

Sweet, R. (1826). Hortus Britanicus. James Ridgway, London. Thellung, A. (1919). Beiträge zur Adventivflora der Schweiz III. Vierteljahrsschr. Naturf. Ges. Zürich 64: $684-815$.

Vahl, M. (1794). Symbolae Botanicae, Vol. 3. Nicolaus Möller et filius. Hauniae [Copenhagen].

(1798). Eclogae americanae, Vol. 2. Nicolaus Möller et filius. Hauniae [Copenhagen].

Vellozo, J. M. da C. (1825) [publ. 1829]. Florae fluminensis. Typographia nationali, Flumine Januario [Rio de Janeiro].

(1827) [pub.1831]. Florae fluminensis: Icones. Domnus Frater Antonius da Arrabida..... Publicae Bibliothecae In Urbe Fluminense praefectus, Flumine [Rio de Janeiro].

Verdcourt, B. (1957). The names of the Morning Glories cultivated and naturalised in East Africa. Taxon 6: 231 - 233.

(1961). The problem of Ipomoea puchella auctt., non Roth. Kew Bull 15: 10 - 13.

(1963). Convolvulaceae. In: C. E. Hubbard \& E. Milne-Redhead (eds), Flora of Tropical East Africa. HMSO, London.

Williams, B. R. M. et al. (in prep.). Insights into Ipomoea s.l. based on molecular studies.

Williams, L. O. (1970). Tropical American Plants XI. Fieldiana, Bot. 32(12): 179 - 206.

Wood, J. R. I., Simão-Bianchini, R. \& Fuentes, A. F (2015). Convolvulaceae. In: B. M. Jorgensen, M. Nee \& S. G. Beck (eds), Catálogo de las Plantas Vasculares de Bolivia 1: 520 - 531. Missouri Botanical Garden Press, St Louis. 
INDEX TO NAMES USED IN IPOMOEA principal reference page numbers in bold type)

abutiloides 2, 3, $10-13$,

$21,22,54,80$

acanthocarpa 2, 3, 9, 37, 38

acuminata 99

adiantifolia 109, 117, 118

alba $3,6,8,12,13, \mathbf{1 0 5}$,

106,107

amazonica 3, 4, 9, 12, 27

amnicola 3, 4, 11 - 13, 25,

$\mathbf{2 9}, 30,54,57,86$

angulata 35

angustifolia 44

anisomeres 92, 95, 96

appendiculata $4,5,10,12$,

13, 46, 53, 57, 58

aprica $4,7,12,13,44$

argentea $4,5,7,12,73,74$,

75

argentinica $4,10,12,13$, $53,54,55-57,59,80$

aristolochiifolia $4,9,12$, 13, 107, $108-110,116$

asarifolia 2, 27

asplundii 82

aurifera 39

australis 89

bahiensis $8,12,31,36$

batatas 2, 3, 9, 10, 12, 13,

86, 87, 88, 92

batatoides $3,8,12,13,65$,

76, 78

bona-nox 105

bonariensis $4,8,11-13$,

77, 79, 80, 81, 82

brasiliana 71

cairica $3,7,12,13,95, \mathbf{9 6}$,

118

caloneura 4, 5, 8, 12, 13, 77, 85

calyptrata 5, 6, $10-12,53$, 63

capillacea 118

cardenasiana 4, 5, 9, 12, 52 , 53

cardiosepala 28

carnea $3,9,12,13$

carolina 88

cerradoensis $4,5,7,12,13$,

39, $40-42$

chacoensis 80

cheirophylla $3,4,8,11$ -

$13,77, \mathbf{8 3}, 86$

chiliantha $3,4,11,12, \mathbf{2 9}$, 54 chiquitensis $4,5,9,12,13$,

18, 19, 20, 29, 46

chodatiana 51

cholulensis 115

chondrosepala 4, 10, 12, 13,

49, 51, 52, 97

chrysotricha 38

clavata $4,11-13,14$

coccinea 113 - 115

congesta 99

contrerasii 14

cordata 21,22

cordatotriloba $3,4,11$ - 13, 87, 88, 89

corymbosa $3,11,12, \mathbf{1 3}, 14$

$-16,65$

crinicalyx $4,8,12,13,16$,

17

cryptica $2,4,5,10-13,37$,

86, 91, 92, 94, 95

cuneifolia 4, 7, 12, 43, 117

cynanchifolia $5,9,12,87$,

90, 91

decora 76

densibracteata $4,5,8,12$,

71, 73, 85

descolei 61

dichotoma 89

diversifolia 101

dumetorum 4, 9, 12, 13, 18,

37, 38, 108, 109, 115, 116, 117

echinocalyx 5, 8, 12, 13,

16,17

echioides 74, 75

eggersiana 71

erecta $\mathbf{8 0}, 81$

exserta 4, 5, 8, 11, 71, 77,

$81, \mathbf{8 2}, 83-85$

federalis 103

fimbriosepala $3,8,12,13$,

22, 23

fistulosa 64

goyazensis $4,8,12,13, \mathbf{7 6}, 77$

gracilipes 118

graminiformis 75

grandifolia 3, 9, 12, 13, 89

graniticola $4,5,7,12,13$,

67, 68, 95

gypsophila $2-5,10,12$,

13, 61, 63

haenkeana $2,4,5,7,12,13$,

$39,40,42,44$

hederacea 102

hederifolia $3,8,12,13$,
$101,106,113,114,115$

hewittacea $4,9,12,13,31$,

38

hieronymi 4, 10, 12, 13, 56,

57, 58, 61

hirsutissima 4, 5, 7, 12, 13,

38, 39, 40

horrida 96

huayllae 4, 5, 11 - 13, 46,

108, 109, 112

igualensis 103

incarnata 5, 11, 12, 25, 33,

35

indica $3,9,10,12,13,98$,

99

indivisa 5, 8, 12, 13, 115

jujuyensis $11-13,61,67$,

116

juliagutierreziae 4, $11-13$,

$46,68,69-71$

kurtziana 58

lactifera $3-5,10,12,13$,

$86,87, \mathbf{9 1}, 92,93$

lanuginosa 4

lilloana 4, 5, 10, 12, 13, 49,

51, 54, 61, 67

lobata $3,8,12,13,110$

longibarbis $4,5,9,12,13$,

$21,53,55, \mathbf{5 6}$

magnifolia 4, 10, 12, 13,

97, 98, 99

marginisepala 4, 9, $11-13$,

95, 103

martii 21

mattogrossensis 36

maurandioides $4,5,10,12$,

$13,27,28, \mathbf{3 0}, 31-35$

mauritiana $3,8,12,13, \mathbf{8 3}$,

85,86

megapotamica $4,10,12$,

$56,57, \mathbf{5 9}, 60$

mendozae $4,5,7,10,12$,

$13,40,44,45,46$

minuta 117

mucronatoproducta $4,5,10$, $12,13,31,32, \mathbf{3 4}, 35$,

mucronifolia $4,5,9,12,46$,

47, 48

muricata $3,8,12,106$,

107

neurocephala $4,9,12,13$, 98, 103

nil $3,9,12,13,98,100$,

101, 102

nitida $4,48,51$ odontophylla 4, 5, 11, 12, 46, 108, 111

oocarpa 107

opulifolia $3-5,9,12,13$, 60, 85

oranensis $4,5,8,11-13$, 71, 77, 81, 82, 83, 99

paludicola $2,4,6,10,12$,

$13,24,25-27$

pandurata 52

paradae $3,4,10,12,66,69$,

71, 72

parasitica $3,7,10,12,13$, 104, 106

pauciflora 69

paulistana $4,5,7,12,13$, 73, 74, 75

pavonii 96

pearceana 21

pedata 83

peredoi 65

philipsonii 76

philomega $3,5,11-13, \mathbf{2 8}$, 52

pinifolia 4, 7, 12, 35, 44

piresii 38

piurensis 2,37

plummerae 2, 4, 7, 12, 109, 117, 118

procumbens $4,7,12,13,28$

procurrens $4,6,7,12,13$, 23, 25, 27, 39, 42

psammophila $4,5,10,12$, $13,39,46,48,49,50,85$ pseudocalystegia 4,46 pubescens 4, 9, 12, 98, 102 , 103

pulchella 118

pulcherrima 69

purpurea 3, 9, 12, 13, 98, 99, 100, 101

quamoclit $3,7,12,13,113$

ramosissima $3,5,9,12,13$, 18, 87, 89, 90, 91

regnellii $3,5,10,13,17,18$ reticulata $3,11-14,54, \mathbf{6 5}$, $66,67,76$

rhombifolia 117

riparia 20

rosea 67

rubens $3,9,11,-13, \mathbf{2 0}$,

21,56

rubriflora $4,8,12,13,106$,

114, 115

salzmannii 36 
INDEX TO NAMES USED IN IPOMOEA (principal reference page numbers in bold type)

santacrucensis 81,82 saopaulista 3, 65, 67 sawyeri 103 schomburgkii 4, 7, 12, 13, 44, 75 schulziana $4,5,8,13,71$, 76, $77-79$ sericophylla 56 sericosepala $3,5,10-13$, 21, 22, 78 serpens $24,27,33$ setifera $3,8,12,13, \mathbf{2 3}$ setosa $3,8,12,17,95,96$ spinulifera $4,5,10,12,13$, $53,60,61,62$

splendor-sylvae 91

suburceolata $5,8,12,13$, 71, 78, 79

tapirapoanensis 85

squamisepala $4,7,12,35$, tarijensis $4,5,11-13,46$, 36

squamosa $3,5,10,12,13$, 36, 37, 91, 92 stachyoides 74 steudelii 71 subalata 59,60 subrevoluta 4, 7, 12, 13, 67, $68,118,119$ subtomentosa 33
$57,65,66,67$
trichocarpa 88

tricolor 3, $11-13,95, \mathbf{1 0 4}$,

105

triloba 89

tuerckheimii 107

turbinata 107

vargasiana 69 uruguayensis 50 villicalyx 20

villosa 74

virgata $4,7,12,13,43$

vivianae $4,10,12,13,54$ wolcottiana 69

wrightii 3, 7, 12, 13, 118 